\title{
VERHANDELINGEN
}

VAN HET KONINKLIJK INSTITUUT VOOR DE TAAL-, LAND. EN VOLKENKUNDE VAN NEDERLANDSCH-INDIE

DEEL 1

\section{DE FACTORIJ DER OOSTINDISCHE COMPAGNIE TE PATANI}

DOOR

Dr. H. TERPSTRA

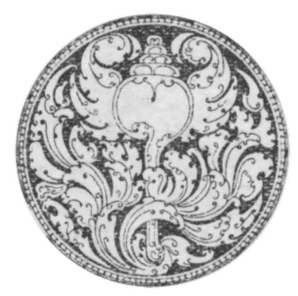

'S-GRAVENHAGE - MARTINUS NIJHOFF - 1938 

Dit werk is een nieuwe historische exploratie aan den vasten wal van Aziё. Na Voor-Indï, Arabï en Persiö richtte ik nu mïn aandacht op. Achter-Indië, waar een tïd lang Patani voor de O. I. C. een hoogst belangrijk middelpunt was. Uit de beschikbare gedrukte en geschreven bronnen trachtte ik een zoo duidelijk mogelijk beeld samen te stellen van de geschiedenis der factorij aldaar. Het bleek, dat ik me niet kon beperken tot dit eene handelscentrum: noodzakelijk moesten ook Sian, Cambodja en andere handelsgebieden in mijn onderzoek worden betrokken. Het is niet mijn bedoeling geweest, al deze "Noorderkwartieren" even uitvoerig als Patani te behandelen: deze plaats bleef hoofdzaak; van de andere streken gaf ik alleen. datgene, wat met het Patanische kantoor verband hield. Toch vertrowwe ik, dat zij, die de andere Noorderkwartieren to voorwerp van studie maken, dikwijls in deze publicatie iets van hun gading zullen vinden.

Ik heb gemeend, soowel een chronologisch relaas te moeten geven als ook een meer systematisch gedeelte, waarin men eenige onderwerpen, die daarvoor in de termen viclen, als b.v. Chineesche en peperhandel, als geheel behandeld vindt. Wat het chronologische deel betreft: de keuze der te vermelden feiten blijft altijd cenigszins subjectief, en de vraag van het meer of minder dringt zich voortdurend aan den geschiedschrijver op. Nu scheen het mij, dat ik niet te spaarzaam met de feiten moest zijn, daar de Compagniesgeschiedenis van Patani allicht niet zoo spoedig weer zal worden onderzocht. Zoo heb ik bijvoorbeeld geen enkel hetzij Nederlandsch hetzij Engelsch schip, dat in dien tijd de stad bezocht heeft, onvermeld gelaten; de itineraria dezer vaartuigen toch kunnen voor velen bij het bestudeeren van denzelfden tijd van belang zijn. Ik hoop, dat aldus dit boek aan bruikbaarheid zal hebben gewonnen voor wie zich meer in't algemeen met het ontstaanstijdperk van ons koloniale rijk bezig houden. Het register en de talrijke verwijzingen mogen hun hiorbij van dienst zijn.

Aan al degenen, die mij bij deze studie met hun inlichtingen en steun verplicht hebben, breng ik mijn hartelijken dank. In 't bijzonder 
geldt dit den algemeenen rijksarchivaris, $M r$. R. Bijlsma, en ook de andere aan het Algemeen Rijksarchief verbonden ambtenaren, niet alleen voor hun steun en inlichtingen bij mijn onderzoekingen in Den Haag, maar ook voor de moeite, die zij zich zoo herhaaldelijk getroost hebben bij het verzenden van archivalia naar het Rijksarchicf to Utrecht, waar ik ook dezelfde welwillendheid mocht ondervinden.

Ieder, die zich met wetenschappelijken arbeid bezig houdt, weet, hoe moeilijk het in de tegenwoordige ongunstige tijden valt, zijn zierk uitgegeven te krijgen. Grooten dank ben ik daarom verschuldigd aan het Koninklijk Instituut voor de Taal-, Land- on Volkenkunde van Nederlandsch-Indië, dat mijn studie als cerste deel van zijn nieuzue serie Verhandelingen heeft willen publicceren, in 't bijzonder aan den secretaris, Dr. F. W. Stapel, voor de belangstelling, die ik bij het uitgeven van dit boek van hem mocht ondervinden.

Hilversum, Maart 1938.

H. TERPSTRA. 


\section{EERSTE HOOFDSTUK.}

\section{De Nederlanders in Patani tijdens de Voorcompagnieën.}

Een der alleroudste Nederlandsche vestigingen in het Oosten is die te Patani geweest, een stad, liggende aan de Oostkust van 't schiereiland van Malakka, op bijna $7^{\circ}$ N.B. De oorsprongen van deze vestiging reiken terug tot voor de stichting der Oostindische Compagnie; tijdens de Voorcompagnieën was de stad een zeer gezocht handelsmiddelpunt, en ook na de vereeniging der afzonderlijke compagnieën in 1602 leggen de bewindhebbers op Patani bijzonderen nadruk, én als handelsplaats, én als bestuursmiddelpunt. 't Is waar, dat Patani aan deze hooggespannen verwachtingen niet beantwoord heeft, en het Compagnieskantoor aldaar den tijd van Coen niet heeft mogen overleven. Toch leek mij de kortstondige geschiedenis der kolonie de moeite van 't bestudeeren waard: de bekoring van dit werk ligt eensdeels hierin, dat het ons voert in den tijd, waarin ons koloniale rijk werd opgebouwd, anderdeels ook in de mogelijkheid om uit de talrijke gegevens, die ons ten dienste staan, een afgerond geheel te maken, niet alleen een opkomstgeschiedenis dus, maar een totaaloverzicht.

De „bocht van Patani” is het middelpunt van een geheel apart handelsgebied; de schepen, die daarheen voeren, konden tevens Jambi, Johor, Siam en de verdere landen van Achter-Indië, ja zelfs Japan aandoen. De stad zelf, van zee uit herkenbaar aan een ten Westen ervan gelegen berg van bijna 1000 M., den Goenoeng Nipiki, was bij de komst der Hollanders omringd door een versterking van groote, vierkante balken; ze lag weliswaar aan zee, maar had geen bruikbare haven. De uit Bantam komende schepen moesten hun

Verh. dl. I. 
waren lossen door middel van sloepen, die over de smalle landtong Saberang werden gesleept, om dan het ondiepe vaarwater bij de stad te bereiken ${ }^{1}$ ).

In verband met de moessons begon eind April of begin Mei de geschikte tijd om schepen van West-Java naar Patani te zenden; October was de geschiktste maand voor de terugreis. Spoedig daarna, gedurende November, December en Januari, maakten de sterke Noord-Oostewinden, gestadig van regen vergezeld gaande, de scheepvaart uiterst bezwaarlijk.

Wat de staatkundige verhoudingen betreft: Patani was de hoofdstad van een gelijknamig koninkrijk, dat, evenals andere staatjes op het schiereiland van Malakka, zooals Sangora en Ligor, onder de suzereiniteit stond van den koning van Siam. Zwaar drukte deze opperheerschappij niet; jaarlijks werd als hulde en teeken van onderdanigheid een gouden bloem met eenige andere geschenken uit Patani naar het Siameesche hof gezonden. Ten tijde van het verschijnen der eerste Hollanders voor Patani, in 1601, regeerde daar een koningin, „die sy”, zoo vertelt Van Neck ons, ,als of het een man waer, coninck nomen, deur d'imperfectie van haerlieder tael". Als haar naam wordt Pratiau opgegeven. Dit is echter een Siameesche titel, gegeven aan heiligen en vorsten ${ }^{2}$ ). Ze was omtrent 50 jaar oud ${ }^{3}$ ), en had reeds ongeveer 15 jaren ,zeer vredich geregeert" met haar mandarijnen ${ }^{4}$ ), als opvolgster van haar man, en dat zeer tot genoegen van de inwoners, die aldus een periode van afpersingen hadden zien volgen door een tijdperk van welvaart. $Z$ ij vertoonde zich weinig aan haar volk, maar hield zich meest tusschen haar

1) Zie over de ligging van Patani vooral Dr. J. W. IJzerman: Hollandsche prenten als handelsartikel te Patani in 1602, in Gedenkschrift Kon. Inst. voor de Taal-, Land- en Volkenkunde v. Ned.-Indië, Den Haag 1926, p. 88 v.; ook G. Arthus: Indiae orientalis pars octava, Frankfort, 1607, p. 38.

2) Volgens inlichting van prof. P. S. van Ronkel. Aan Ir. L. F. van Ravenswaay te Zeist ben ik de verklaring van Phra verschuldigd, als beteekenend: verheven.

3) Pieter Willemsz. Floris, Nederlander in Engelschen dienst, die in 1612 en 1613 in Patani was, schrijft: ,shee was tall of person and full of majestie, having in all the Indies not seene many lyke unto hir" (Peter Floris, his voyage to the East Indies in the Globe, 1611-1615, ed. by W. H. Moreland, Hakluyt Society, London 1934, p. 62.

4) Daar deze term herhaaldelijk in de bronnen voorkomt, ben ik geneigd om, in afwijking van IJzerman (p. 84), ook zelfs bij de passage; „die sij mentery nomen" te denken aan mandarijnen, hoezeer deze vorm ook aan Mal. mantěri (raadsheer, minister) doet denken. Beide vormen correspondeeren trouwens met sanskriet: mantrin : raadsheer. 
vrouwen op in het koninklijk paleis, dat ,met gulden penelen, ende andere gesneden houtwercken gewracht" was ${ }^{1}$ ).

De berichten, welke de Hollandsche bronnen ons brengen omtrent bevolking en godsdienst van Patani, geven den indruk van bonte verscheidenheid. Dit is begrijpelijk, als men in aanmerking neemt, dat de stad gelegen was in het overgangsgebied van twee rassen (Maleiers en Zuid-Oostelijke Mongolen) en verder van twee godsdiensten (Islam en Boeddhisme). Van de ruim 10000 weerbare mannen, waarover Patani kon beschikken, vormde het oorspronkelijk Maleische en Mohammedaansche volk ongeveer een derde gedeelte. Deze Maleiers zijn, zoo lezen we, ,van coleure tusschen wit en swart, niet onaengenaem, dispost ${ }^{2}$ ) van leden, seer fien van ganck, prachtich ${ }^{3}$ ) en veel van hen selven houdende". Hun hoofdbezigheden zijn landbouw en vischvangst. Maar de handwerken en den handel ter zee laten ze over aan het Chineesche bestanddeel der bevolking. De Chineezen munten uit door werkzaamheid en ook door listigheid; zij „ontsien haer geen moeyten, arbeyt, noch valsheyt, dieverie, noch geen soo snooden dinck om gelt te winnen". Zij zijn dan ook in Patani het rijkst en staan in hooge gunst bij de koningin. De derde bevolkingsgroep, die der Siameezen, is economisch van weinig beteekenis. Chineezen en Siameezen zijn ,groote afgooden dieners, niet van een gevoelen, maer van diverse secten", welke secten natuurlijk alle min of meer bij het Boeddhisme moeten ondergebracht worden.

Ook op taalkundig gebied was Patani een veelzijdige plaats; Maleisch, Siameesch, Chineesch en Patanisch werden er gesproken, Maleisch het meest ${ }^{4}$ ).

Het land van Patani was vruchtbaar, en leverde rijkelijk lijftocht

1) Vgl. over het bestuur: Arthus p. 35, 41; Journaal van Roelof Roelofsz (in Begin ende Voortgangh van de Vereenighde Geoctroyeerde Oost-Indische Compagnie I, Amsterdam 1646) p. 18; Fr. Valentyn: Oud- en Nieuw OostIndiën III IIc (1726, Dordrecht-Amsterdam) p. 89; J. K. J. de Jonge: De opkomst van het Nederlandsch gezag in Oost-Indië, Amsterdam-Den Haag, d1. II (1864) p. 92 (d1. III, 1865, p. 19, geeft over 't hof in Patani een blijkbaar te ongunstig beeld); P. A. Tiele: De Europeërs in den Maleischen Archipel 1519-1618, in Bijdr. Inst. Taal-, Land- en Volkenkunde v. Ned.-Indië 18771887, reeks 4, VI p. 178 en 5, II p. 241 noot 2; Reisverhaal van Jacob van Neck voor bewindhebbers, 28 Juni 1600-15 Juli 1603; J. P. Coen aan bewindhh. te Amst., Bantam, 1 Jan. 1614, afgedrukt bij Colenbrander: Jan Pietersz. Coen

I p. 1 v.; Hendrik Janssen aan bewindhh. te Amst., Patani, 25 Oct. 1616.

2) Vgl. Fr. dispos : behendig.

3) D.i. prachtlievend.

4) Vgl. over de bevolking vooral: Arthus p. 38 v.; Roelof Roelofsz p. 13, 16 v., 19; 't reisverhaal van Van Neck, genoemd op p. 2 , noot 4. 
op. Bij de komst der Hollanders was er in overvloed rijst te krijgen, verder fruit, vleesch en visch. Ook peper behoorde tot de producten des lands, hoewel die er weinig groeide. Industrieel was Patani eenigszins van beteekenis, doordat er kleedjes werden gewezen ${ }^{1}$ ); evenwel waren in dit opzicht Koromandel en Suratte onvergelijkelijk belangrijker. Een eigenaardig handelsartikel waren er de roggevellen, waarop.soms buitensporige winst gemaakt werd (drie gulden inkoop per stuk, ruim honderd gulden verkoop!). Deze vellen werden gebruikt „tot scheyden, hechten ${ }^{2}$ ) ende custadien ${ }^{3}$ ) om haar geweer, sadel ende alderhande hantwerck" ${ }^{4}$ ).

Maar indien Patani alleen datgene aan te bieden gehad had, wat 't land zelf opleverde, zou er nooit een Nederlandsch handelskantoor van eenige beteekenis verrezen zijn. Het is de positie van toegangspoort tot Oost-Azië, die de plaats belangrijk maakte als emporium, waar handelaars uit allerlei streken hun goederen kwamen brengen. Inwoners van Malakka en Bengalen voerden lijnwaad aan, Javanen sandelhout ${ }^{5}$ ), de inwoners van Borneo slaven, kamfer, sago, was en bezoarsteen ${ }^{6}$ ), de Siameezen goud, rijst, zout, lood en benzoë ${ }^{7}$ ), of, zooals de Hollanders ook zeggen, benjuwijn, die van Cambodja slaven, katoen en calamba-hout, de Japanners zwaarden, bontwerk en koper. Maar verreweg het belangrijkst als importeurs waren de Chineezen, die zijde, zijden waren en nog andere artikelen aanbrachten op hun jaarlijksche tochten. Het is vooral hieraan, dat Patani zijn kortstondigen bloei als handelskantoor te danken gehad heeft ${ }^{8}$ ).

Het begin van de vestiging der Nederlanders in Patani is verbonden aan den naam van Jacob van Neck, die als admiraal in dienst van de

1) Hierover nader in hoofdstuk III.

2) Heften.

3) Lees : custodiën : foudralen dus.

4) Zie Roelof Roelofsz p. 17; Valentyn III IIc p. 90; De Jonge II p. 92; 't reisverhaal van Van Neck; een kopie-memorie van de waren, dienstig op Japan.

5) Belangrijk als reukhout en medicijn.

6) Ingewandssteen van sommige dieren, als tegengif gebruikt. Zie nader: Pieter van Dam, Beschryvinge van de Oostindische Compagnie, uitg. Dr. F. W. Stapel, I I, register sub voce.

7) Welriekende gomhars, gebruikt voor medicamenten, reukwerken en als wierook.

8) Vgl. over de handelsgelegenheid in Patani: Arthus p. 41 v.; De Jonge II p. 92 en document XVII; G. P. Rouffaer en H. H. Juynboll : De batik-kunst in Ned.-Indië en haar geschiedenis, Utrecht 1914, I, bijlage III; Van Dam II I p. 324 ; J. E. Heeres: Hendrik Janssen, Ind. Gids $1896,18^{\circ}$ jaarg. deel I p. 103 v.; 't reisverhaal van Van Neck. 
z.g. Oude Compagnie ${ }^{1}$ ) als bevelhebber over zes schepen op 28 Juni 1600 't vaderland verliet. Het is hier natuurlijk niet mijn bedoeling, den admiraal op al zijn zwerftochten te vergezellen. Genoeg zij het, te vermelden, dat hij in Juli 1601 met het schip Amsterdam en 't jacht Gouda Ternate verliet met bestemming naar Patani. Door tegenwind echter veranderde hij zijn plan en zette hij koers naar China. Het gelukte hem niet, hier tot handelsbetrekkingen te komen, integendeel: Van Neck moest China verlaten met achterlating van een aantal manschappen, die voor het grootste deel door de Portugeezen te Macao gedood werden. 3 October vertrok hij nu inderdaad naar Patani, waar eindelijk een loods hem op 7 November ter reede bracht ${ }^{2}$ ). Dadelijk kwam een inlander van hoogen rang aan boord ,wiens officie is de scheepen te besichtigen", meebrengende eenige vruchten van 't land, en met de mededeeling, dat die van Patani door de komst der Nederlanders ,zeer verblyt” waren. Van hun kant onthaalden dezen den Patanischen afgezant zoo goed mogelijk. Van Neck heeft zich zelf blijkbaar niet dadelijk aan de kust willen wagen: hij had gehoord, dat de Pataniërs een bedrieglijken aard hadden, en ervaringen als die voor Macao waren wel geschikt, hem voorzichtig te maken. Hij trachtte daarom de beide volgende dagen door 't zenden van de opperkooplieden Rochus Pieterz. en Jan Huyaert, waarvan de eerste met de taal der inlanders eenigszins bekend was, tot 't vestigen van handelsbetrekkingen te komen. Maar daar de inlanders bleven eischen, dat de admiraal persoonlijk zou komen, ging deze 10 November als hoofd van een deputatie naar land, waar hij met groote plechtstatigheid ingehaald werd: twee olifanten stonden aan 't strand gereed om het gezelschap naar 't paleis te brengen, waar de ontvangst niets te wenschen overliet, ,ende ons patent wert den grootsten van 't lant in Arabische sprake voor geleesen, ende door haerlieder bisschop promtelyc vertaelt, die (!) haer altesamen wel geviel”. De koningin, door een geschenk welwillend jegens de Hollanders gestemd, verklaarde, dat dezen naar hun believen in Patani handel mochten drijven ${ }^{3}$ ). Practisch kon hiervan echter niets komen, vóór een van

1) Zijnde een combinatie der Compagnie van Verre met de z.g. Nieuwe Compagnie voor den handel op Oost-Indië.

2) Vgl. over 't bovenstaande vooral: De Jonge II, p. 242 v.; Tiele Eur. 4 VI p. 177 v.; W. P. Groeneveldt: De Nederlanders in China (Bijdr. Taal-, Land- en Volkenkunde v. Ned.-Indië, $6^{\mathbf{e}}$ volgreeks, $4^{\mathbf{e}}$ deel, Den Haag 1898) p. 9; H. P. N. Muller, Onze vaderen in China, Gids 1917 dl. I p. 322 v.

3) IJzerman, p. 91, geeft als datum van dit onderhoud ten onrechte 9 Nov. 
de aanzienlijke inlanders, Sirinara ${ }^{1}$ ) genaamd, en door de koningin daartoe aangesteld, het omtrent den prijs van de peper met de Hollanders eens geworden was. Dit ging niet gemakkelijk: de inlanders trachtten den prijs, die, naar Van Neck zegt, voor zijn komst 15 realen van achten ${ }^{2}$ ) per baar ${ }^{3}$ ) bedroeg, op te drijven tot 50 , hoewel ze spoedig 10 lieten vallen. Begrijpelijkerwijze wilde Van Neck hier niet op ingaan; er werd zelfs op 10 en 11 November een schijnbeweging door de Nederlandsche schepen gedaan, alsof men voorgoed van de kust wilde vertrekken. Daar dit de inlanders echter niet imponeerde, en bovendien de zee door de hevige winden moeilijk bevaarbaar was, besloten de Hollanders, alsnog de onderhandelingen over den peperprijs voort te zetten, en dan tevens te trachten, hun lading van de hand te doen. Het spel van loven en bieden, van plichtplegingen en geschenken, duurde tot 6 December. Toen begaf zich de admiraal naar het huis van den sabandar ${ }^{4}$ ), waar hij door de inlanders werd onthaald op „confitueren ende ander lieflijckheden”, en ten slotte een bindend contract wist af te sluiten, waarbij de baar peper van 380 pond met 30 realen van achten betaald zou worden, terwijl de koningin aan tol $5 \%$ zou ontvangen ${ }^{5}$ ). Reeds 17 November daaraan voorafgaande was besloten, dat men den onzen een huis zou gaan timmeren om er de meegebrachte koopmanschappen in te bergen, aan welk plan dadelijk uitvoering gegeven was ${ }^{6}$ ).

De inlanders hielden zich bij voortduring aan den vastgestelden peperprijs van 30 realen. Men ontving echter spoedig mindere kwaliteit, doordat er stof in gemengd was. Van Neck liet 't wegen van dit „onsuijver goet” stop zetten en eischte van Sirinara, dat de peper, evenals aanvankelijk geschied was, stofvrij geleverd zou worden. Deze

1) Ook wel Dato Sirinara. Hij was rentmeester, blijkens journaal-Van Warwijck in Begin ende Voortgangh I, p. 43. Door inlichtingen van verschillenden kant is mij gebleken, dat Dato of Datoh (= datoek) een Mal. titel voor stamhoofden en hooge ambtenaren is, Sirinara daarentegen een quasiSanskriet-titel.

2). De in Indië zeer gebruikelijke handelsmunt van ongeveer 2 gulden en 5 stuivers.

3) Van 380 pond.

4) Havenmeester.

5) Dit contract bij J. E. Heeres, Corpus Diplomaticum Neerlando-Indicum I (Bijdr. Taal-, Land- en Volkenk. v. N.-Indië, Den Haag 1907) p. 15 v. De datering aldaar, 10 Nov. 1601, is blijkens het bovenstaande onjuist. Zij kan alleen betrekking hebben op 't begin der onderhandelingen. Vgl. trouwens reeds de opmerking van Heeres in zijn art. over Hendrik Janssen, p. 104.

6) Valeintyn III IIc p. 90 geeft over onze errste betrekkingen met Patani een in bijzonderheden weinig juiste voorstelling. 
beweerde echter, dat men de onzuivere peper zelf aldus uit Jambi ontving, en er dus niet voor aansprakelijk was. Van Neck gaf echter niet toe, en de kwestie bleef eenige dagen hangende, totdat tenslotte de koningin een beslissing ten gunste der Hollanders nam: de peper zou, voor ze aan de vreemdelingen geleverd werd, gezift moeten worden.

Dat de komst van Van Neck en de zijnen een reden tot naijver was voor andere handelaren, zooals de Portugeezen, is te begrijpen. De benijders waren evenwel met machteloosheid geslagen, daar de macht van Van Neck te groot voor hen was. Wel werd op 26 Januari 1602 een aanslag op de twee schepen beraamd door Siameezen, die met zes jonken voor de kust van Patani lagen, en voor hun doel zich den bijstand hadden weten te verzekeren van 200 Japanners, die zich des te gereeder tot de onderneming wilden leenen, daar ze in dienst stonden van de Portugeezen. Van Neck echter ontdekte den toeleg tijdig, en rustte ostentatief zijn schepen tot den strijd uit, hoewel op de Amsterdam dertig man zich niet konden roeren „soo van quade beenen, als van 't rood melisoen ${ }^{1}$, ende andere kranckheden". De S:ammers echter, onbekend met deze omstandigheid en blijkbaar geïmponeerd door 't wapenvertoon, gaven hun plan op ${ }^{2}$ ).

Den $26^{\text {en }}$ Mei 1602, toen Van Neck nog ongeveer 500 baren peper ontbraken tot het volladen van zijn schepen, werd hij verontrust door de verschijning van twee nieuwe schepen voor de stad; in onzekerheid zijnde omtrent de herkomst daarvan liet hij het geschut van de Amsterdam en de Gouda in orde maken en bereidde hij $z^{*}$ ch op strijd voor; er werden echter geen vijandelijke.... maar saluutschoten gelost: de nieuw aangekomen schepen bleken uit Zeeland afkomstig te zijn; 't waren de Middelburg en de Zon, uitgezonden naar Indië dcor de vereenigde Zeeuwsche Compagn:e ${ }^{3}$ ) onder de opperkooplieden Gerard le Roy en Laurens Bicker. In Augustus 1601 met de Zeelandia en de Langeberque te Atjeh aangekomen, hadden ze daarna

1) Melisoen: vgl. Middelned. menisoen: roode loop.

2) Vgl. over 't voorgaande: Arthus p. 35 v.; Roelof Roelofsz p. 7 v.; Valentyn III IIc p. 90 ; Overzicht der betrekkingen van de Ned. O. I. C. met Siam, in Tijdschr. voor Ind. Taal-, Land- en Volkenkunde van 't Bat. Gen. v. Kunsten en Wetenschappen XIII, 1864, p. 410 en bij1. I; De Jonge II p. 242 v. en bij1. XIV en XXV; Tiele, Eur. 4 VI p. 177 v.; IJzerman p. 86 v.; Heeres: Hendrik Janssen p. 104; Heeres Corpus Dipl. I p. 15 v.; Van Dam II I 324; 't resiverhaal van Van Neck.

3) Gevormd uit de Middelburgsche Comp. van Ten Haeff en 't grootste deel der participanten van de Veersche van De Moucheron. Deze laatste zelf maakte echter geen deel van de combinatie uit. 
een zwerftocht door den archipel gedaan langs Bantam en Amboina, om daarna in Patani eindelijk op voordeelige wijze hun lading te verkrijgen. De verhouding tusschen Hollanders en Zeeuwen was vriendschappelijk; de laatsten hielpen b.v. Van Neck aan 2000 pond „bisquyt ofte broot". Mocht Van Neck aan den eenen kant blij zijn, niet met vijanden maar met landgenooten te doen te hebben, toch was natuurlijk de komst dezer handelsconcurrenten hem niet in alle opzichten aangenaam: de inlanders zouden licht van de groote vraag naar hun peper misbruik kunnen maken. $\mathrm{Hij}$ stelde daarom de nieuwaangekomenen in kennis van den afloop zijner onderhandelingen over den peperprijs, en ried hun in 't bijzonder, zich ook te houden aan den eisch, dat alleen gezuiverde peper zou worden geleverd. Le Roy bleek evenwel minder kieschkeurig dan Van Neck, ,seggende, indien hy ' $t$ niet ongesift en wilde, dat andere haest volgen souden, die het alsoo wel blydelijck souden willen aenvaerden". En verder: de peper was hier voor de Zeeuwen wel de helft goedkooper dan in Atjeh. Nu moest Van Neck wel tegenover de inlanders de zelfde meegaandheid betrachten; hij deed nu echter de peper op eigen kosten ziften, wat op een verschil van wel $6 \%$ kwam te staan. Aldus verkregen zoowel de Hollandsche als de Zeeuwsche schepen hun volle lading.

Koningin Pratiau, verheugd over het voordeel, door de Hollanders en Zeeuwen aan haar onderdanen gebracht, liet hun gelijkelijk eer wedervaren. Terwijl ze zich anders zelden in 't openbaar vertoonde, werden de Nederlanders nu tot twee maal toe uitgenoodigd, haar bij een openbare feestelijkheid te vergezellen. Zoo werd 24 Juni 1602 een groote „triumphe” gehouden, waarbij de koningin verscheen, geescorteerd door wel 4000 gewapende mannen en een 150-tal olifanten, ,,daer af de sommighe seer cierlijck toeghemaeckt waren, met namen den olyphant, daer de Coningin op reedt met haer dochterken, die soo heerlijck opgepronckt en verciert was, dat een mensch luste, die 't sagh". De Nederlanders van hun kant verschenen met 50 musketiers, ,om den staet te helpen vermeerderen", en lieten hun trompetters, ,al op 't cierlijckste toeghemaeckt met haer beste kleederen, ende nieuwe Oraenjen-vlagghen aen haer trompetten", het Wilhelmus blazen, ,waer over de Coninginne ende haren adel seer verwondert waren, als die haer leven sulck gheluyt niet ghehoort en hadden". Zij stak, toen de onzen dicht langs haar olifant trokken, het hoofd uit de tent, ,om haer immers wel te deghen te besien”.

Toen nu alle vier schepen hun lading hadden verkregen, namelijk de Hollandsche schepen \pm 3000 baar peper en de Zeeuwsche 1300 , 
werd een afscheidsbezoek bij de koningin gebracht. Dat zij hierbij persoonlijk verscheen, werd als een groote eer beschouwd. $\mathrm{Zij}$ beloofde, de Nederlanders, die achter zouden blijven, onder haar bescherming te nemen, verzoekende, ,dat men daer geen dronckaerts maer goede luyden soude laten", hetwelk beloofd werd. Verder verzekerden de Nederlanders op verzoek van Pratiau, Patanische schepen, die ze eventueel tegenover vijanden in nood zouden zien, zooveel mogelijk te zullen helpen. Bij dit afscheidsbezoek werd aan Van Neck, aan Rochus Pietersz. en aan Gerard le Roy ieder een kris verleend.

Als resultaat van het bezoek der Hollanders en Zeeuwen bleven in Patani twee factorijen achter: aan 't hoofd van de Hollandsche stond Daniël van der Leck uit Rotterdam ${ }^{\mathbf{1}}$ ) als opperkoopman, terwijl Pieter Walichsz., een broer van Rochus Pietersz. ${ }^{2}$ ), als onderkoopman bleef ${ }^{3}$ ); zij werden geassisteerd door ,,ses vrome gesellen en een jongen”. De opper- en onderkoopman waren beide ,tamelyck in 's lands tale ervaren". Wat de Zeeuwen betreft zijn we minder goed op de hoogte: we weten alleen, dat ze vrij wat geld en koopmanschappen achterlieten onder de hoede van acht man. Wie echter aan 't hoofd hunner factorij kwam te staan, ontgaat ons $\left.{ }^{4}\right)^{5}$ ).

Nog wachtte den Hollanders en Zeeuwen voor hun. vertrek uit Patani een eigenaardig verrassing: ten derden male kwamen twee schepen uit Nederland deze stad bezoeken, en wel op 19 of 20

1) Hij was met Olivier van Noort door Straat Magalhães gevaren en door Van Neck op Ternate aangetroffen. (Zie: De reis om de wereld door Olivier van Noort, uitg. J. W. IJzerman, Linsch. Ver. XXVII en XXVIII, dl. II p. 69).

2) Het zal dus wel een halfbroer geweest zijn.

3) Door IJzerman, p. 95 noot 1 , is er reeds op gewezen, dat De Jonge II p. 245 ten onrechte zegt, dat Van Neck de leiding der factorij aan Pieter Walichsz. heeft opgedragen. Vgl. verder IJzerman p. 94 noot 2, waar eenige bijzonderheden over Van der Leck voorkomen.

4) Valentyn (p. 90 v.) wijst op de mogelijkheid, dat zekere Gotard Artus van Danzig aan 't hoofd der Zeeuwsche factorij gesteld is. Dit zal wel een verwarring zijn met den auteur, genoemd op p. 2 noot 1 . In 1604, zoo heeft Val. gevonden, is Jacob Roussel hoofd van deze factorij geweest. Dit laatste klopt met Begin ende Voortgangh I, reis van Van Warwijck, p. 74 en 77. Dat de Zeeuwsche factorij geen eigen gebouw $\mathrm{kreeg}$, maar in een gehuurd huis gevestigd werd, is duidelijk uit ditzelfde reisverhaal, p. 46.

5) Vgl. over de komst der Zeeuwsche schepen en wat daar op volgt: Arthus p. 37 v., p. 41 ; Roelof Roelofsz p. 14 v., p. 18 v.; Valentyn III IIc p. 90 v.; De Jonge II p. 244 v., 258 v. en bijl. XIV, XVII en XXIX; Tiele Eur. 4 VI p. 187; De reis van Mahu en De Cordes, uitg. F. C. Wieder, Linsch. Ver. XXI, XXII en XXIV, dl. III p. 36; IJzerman p. 92 v.; 't reisverhaal van Van Neck; Pieter Walichszoon van Delft aan beww. van de oude Oostindische Comp. te Amst., Patani 4 Aug. 1602; Copie-brief van Cornelis Jolyt, Nicolas Pieterss, Jan Martssens en Luijcas Andieuniss aan ?, Atjeh, 3 Sept. 1602. 
Augustus 1602. Als admiraal hierop kwam de bekende Jacob van Heemskerck, die aan 't hoofd van acht schepen in April 1601 uit 't vaderland vertrokken was in dienst van de z.g. Eerste Vereenigde Compagnie op Oost-Indië te Amsterdam ${ }^{1}$ ). 27 Juli 1602 vertrok hij met de beide schepen Alkmaar en Witte Leeuw van Joertan in OostJava naar Patani, welke plaats hem in zijn instructie als peperhaven aanbevolen was. Zijn plan, onderweg nog Johor aan te doen, teneinde met den sultan aldaar vriendschappe'ijke betrekkingen aan te knoopen, mislukte door wind en stroom, en z.0o verscheen hij op 19 of 20 Augustus voor Patani $\left.{ }^{2}\right)$. Hij was zeer verwonderd, daar Van Neck, wiens bezoek aan Patani hem :iiet onbekend gebleven was, nog aan te treffen, en bovendien nog de twee Zeeuwsche schepen, die ook hun lading gekregen hadden. De goede kans voor peperinkoop was dus voor dat oogenblik vervlogen.

Met Van Neck ging Heemskerck op de meest vriendschappelijke wijze om: ze konden immer elkander nauwelijks als concurrenten beschouwen: de compagnie van Van Neck was een onderdeel van die van Heemskerck geworden, al bleef de door den eerste gestichte factorij een afzonderlijke rekening vormen. Van Neck onderrichtte Heemiskerck dus omtrent de handelsgelegenheid van 't land en ging met hem naar den sabandar, in wiens gunst hij hem aanbeval. De beide admiraals kwamen bij elkaar ten maaltijd en vertelden elkander daarbij hun wedervaren. Van Neck stelde voor, bij in- en verkoop samen te werken, om de winsten aiet door concurrentie te verkleinen, een voorstel, dat Heemskerck's goedkeuring wegdroeg, voor zoover het zonder nadeel van zijn rekening kon geschieden.

Nadat nu Van Neck zijn achterblijvenden factorijhouders bevolen had, Heemskerck bij alle voorkomende zaken behulpzaam te zijn, nam hij van dezen afscheid, en vertrok op 22 of 23 Augustus naar Bantam, waar hij na een langdurigen tocht vol tegenspoeden op 6 November aankwam. De Zeeuwen vergezelden hem op deze reis ${ }^{3}$ ).

1) Niet te verwarren met de V.O.C. We hebben te doen met een combinatie van de „Oude Compagnie”, de Nieuwe Brabantsche en een ontworpen Westfriesche.

2) Wieder III p. 36 meldt ten onrechte, dat Heemskerck met de Witte Leeuw en de Enkhuizen voor Patani kwam.

3) Vg1. over de komst van Heemskerck: Arthus p. 37 v., p. 43; Roelof Roelofsz p. 25; De Jonge II p. 244 en 270 v., en bijlagen XV, XVII, XX, XXVIII, XXIX en XXXII; Tiele Eur. 4 VI p. 179 v. en 195; „Discours ende advertentie" (medegedeeld door P. A. Tiele in Bijdr. en Med. v/h. Hist. Gen. dl. VI p. 243 v.); Wieder III p. 36; IJzerman p. 93 v.; het reisverhaal van Van Neck; Jacob van Heemskerck naar Bantam, Patani, 22 Aug. 1602; 
Heemskerck bleef aldus met zijn beide schepen alleen achter. Daar hij, hoewel van nature met Van Neck verbonden, een nieuwe, grootere compagnie vertegenwoordigde, heeft hij het noodig gevonden, daarvoor een nieuwe loge in Patani te stichten (de derde dus al in deze plaats!). Hij ging alzoo spoedig na zijn aankomst over tot het bouwen van een groot, houten huis, van 60 bij 24 voet, om zijn koopmanschappen daarin te bergen. Liever had hij een steenen gebouw gesticht, maar de Portugeezen zouden dan al te licht de Pataniërs bevreesd kunnen maken voor machtsbegeerte van de Hollanders. Daar echter een houten gebouw het nadeel opleverde van groot brandgevaar, groef men uit voorzorg er een gracht omheen, om het aldus van de omgeving te isoleeren.

Heemskerck had, zooals we reeds opmerkten, bij zijn komst zijn handelskansen somber ingezien, en inderdaad had natuurlijk het groote aantal schepen, dat op de reede lag, een neiging tot prijsstijging der inlandsche artikelen tengevolge. Toch gelukte het hem nog om voor den reeds genoemden prijs van 30 realen ruim 1000 baren peper, al was ' $t$ dan ook ongezuiverde, te koopen, dat is dus niet zoo heel veel minder dan de Zeeuwen gekocht hadden. Voor zoover hij echter peper met sandelhout en lood betaalde, werd voor die artikelen een zoo lage prijs berekend door de inlanders, dat Heemskerck alleen door zijn aanstaand vertrek erin berustte, in deze transactie toe te stemmen. Behalve peper wist hij zich ook nog een partij porselein en koperwerk en ook kleedjes te verschaffen, benevens ongeveer 80 lasten $^{1}$ ) rijst.

Voor zijn vertrek maakte Heenskerck met Van der Leck sen regeling omtrent den verkoop van de goederen, door Van Neck en hemzelf achtergelaten, waarbij we zien, dat de reeds boven genoemde financieele samenwerking voortgezet werd: men zou namelijk zijn voorraden, voor zoover ze eenigszins in aard met elkaar overeenkwamen, samendoen in een verhouding van één deel door Van Neck te leveren tegen twee deelen van Heemskerck's goederen, zoo, dat

Jacob van Heemskerck aan Beww., Bantam, 27 Aug. 1603 (Loketkast der S.-G., Afdeeling Processen). Merkwaardig is het, dat Roelof Roelofsz in zijn verhaal totaal geen melding maakt van Heemskerck's komst.

1) Met dit woord kan een verschillend gewicht bedoeld zijn. Ruwweg zouden we een last op 2000 K.G. kunnen stellen. Ik heb het woord last wel aangetroffen afwisselend met cojang in dezelfde beteekenis. Bij W. C. H. Staring: Maten, gewichten en munten $4^{e} \mathrm{dr}$., Schoonhoven 1902, vind ik (p. 92) voor Indië een gewicht, dat varieert tusschen ruim 1667 en ruim 1852 K.G., voor de Strait-Settlements (p. 110) echter ruim 2421 K.G. 
de daarop te maken kosten en de te innen prijs in de zelfde verhouding zouden worden verdeeld; een partij lood en sandelhout van Heemskerck alsmede een groote som gereede penningen van Van der Leck zouden buiten deze regeling blijven. 16 November 1602 vertrok Heemskerck met zijn schepen ${ }^{1}$ ), nadat hij bij zijn goederen elf van zijn mannen in de door hem gestichte factorij had achtergelaten, onder 't gezag van Gerrit Dirkss. en Hans Roeff. Dezen schijnen evenwel onder toezicht van Van der Leck gestaan te hebben, althans aan hem en Pieter Walichsz. worden officieel de goederen in handen gesteld, welke Heemskerck achterlaat.

De admiraal was van zins geweest, na zijn bezoek aan Patani naar Banda te varen om daar zijn schepen vol te laden; ook een tocht naar Siam behoorde nog tot zijn plannen. Hij wijzigde deze echter doordat hij erop gewezen werd, dat hij met kans op voordeel jacht zou kunnen maken op de uit Macao komende Portugeesche kraken. Hij had hiermee inderdaad succes: voor Johor viel hen op 25 November 1603 de kraak S. Catharina in handen. Na een verder oponthoud voor Johor, waar eveneens een aantal Nederlanders aan land werd gelaten, kwam Heemskerck eindelijk op 20 Juni voor Bantam ${ }^{2}$ ).

In 1602 is de belangstelling der Nederlanders voor Patani wel buitengewoon groot geweest. We zagen reeds, dat er in dat eene jaar zes schepen op de reede gelegen hebben. En hiermee is nog niet alles gezegd: laat in het jaar verschenen er nog twee schepen, behoorende bij Van Neck's vloot. Dit waren de Haarlem en de Leiden, staande onder het bevel van den vice-admiraal Gaspar van Groesbergen. Ze waren oorspronkelijk, volgens lastgeving van Van Neck,

1) De brief van Heemskerck aan Beww., genoemd op p. 10, noot 3, heeft hierbij nog: „ende de jacht”. Welk jacht dit geweest kan zijn, is mij niet duidelijk.

2) Vgl. over het voorgaande De Jonge II p. 270 v. en bijl. XXIX; E. Netscher: De Nederlanders in Djohor en Siak 1602 tot 1685, Verhandelingen v. h. Bataviaasch Genootschap, d1. XXXV, Batavia 1870, p. 8; Tiele Eur. 4 VI p. 195 v.; Heeres: Hendrik Janssen p. 104; Fruin Verspreide Geschriften III p. 382; Muller: Onze Vaderen in China I p. 323; Wieder III p. 36; „Discours ende advertentie", genoemd op p. 10 noot 3; Heemskerck naar Bantam, Patani 22 Aug. 1602; Factuur van koopmanschappen, door Heemskerck uit de Witte Leeuw en de Alkmaar overgeleverd aan Daniël van der Leck en Pieter Walichsz., Patani, 16 Sept. 1602, Loketkast S.-G., afd. Processen; Copie-factuur van door Heemskerck aan dezelfden geleverde goederen uit dezelfde schepen, Patani 30 Sept. 1602, Loketkast S.-G., afd. Processen; Heemskerck aan Beww., Bantam, 27 Aug. 1603, Loketkast S.-G., afd. Processen; Van der Leck aan Van Neck te Bantam en in absentie aan beww. „van de eerst ende vereenichde Compangie op Oostijndien" te Amst. 
naar China bestemd, het land, waarvoor zulk een overgroote belangstelling bestond. Maar evenmin als 't Van Neck zelf gelukt was, werd nu in China handel verkregen: Van Groesbergen heeft dit land zelfs niet bereikt; hij is niet verder gekomen dan de Oostkust van Achter-Indië, alwaar door verraderlijk optreden van de inlanders 23 Nederlanders werden vermoord, de vice-admiraal zelf gevangengenomen en eerst tegen een losprijs weer bevrijd. De gelegenheid om naar China te varen verliep, en Van Groesbergen zette koers naar Patani, waar hij 28 December 1602 aankwam. Van zijn langdurig verblijf aldaar, waarover de bronnen zeer weinig mededeelen, weten we, dat de schepen er verversching en hun volle lading verkregen, en 6 September 1603 koers zetten naar Bantam. Elf dagen later kwamen ze echter voor Patani terug, daar de Haarlem onzeewaardig gebleken was, en in genoemde plaats moest achterblijven. De Leiden vertrok daarop op 24 September definitief, en kwam 15 November op de reede van Bantam aan ${ }^{1}$ ).

Evenals elders in Indië was ook in Patani gebleken, hoe slecht de concurrentie van vrijelijk concurreerende compagnieën werkte. De dwaze toestand, dat er in deze plaats niet minder dan drie factorijen waren opgericht, die op den duur onvermijdelijk in conflict met elkaar zouden moeten geraken, eischte ook hier centraliseerend ingrijpen, temeer daar de inlanders den peperprijs en de Chineezen dien van hun zijde allicht tot in 't onredelijke zouden trachten op te drijven, waar er zooveel koopers waren. Een opvallend feit nu in dit verband is, dat reeds tijdens het verblijf van de Haarlem en de Leiden aan de kust de nieuwe tijd zich aankondigde, en wel door een, zij het dan ook kort bezoek van twee schepen der algemeene geoctroyeerde Oostindische Compagnie, die in 1602 in 't vaderland, door toedoen van den Advocaat van den lande Johan van Olden-

1) Vgl. over de Haarlem en de Leiden: Roelof Roelofsz p. 27 v. (het hier bedoelde deel is eigenlijk van schipper Cornelis Claesz, vgl. Tiele 4 VI p. 180 noot 1); Reis Warwijck (in Begin ende Voortgangh I) p. 43 en 45; De Jonge II p. 245 v. en III p. 19 (De Jonge stelt het verblijf der twee schepen voor Patani te kort, namelijk op 7 maanden; verder geeft hij ten onrechte den indruk, dat, toen de Leiden van Patani naar Bantam vertrok, de Haarlem reeds verbrand was, hetgeen inderdaad pas later gebeurde); Tiele Eur. 4 VI p. 180, 216 en 218 (onjuist is Tiele, als hij op p. 218 zegt, dat Cornelis Pietersz op 4 Nov. 1603 te Patani de schepen onder G. v. Groesbergen aantrof : alleen de Haarlem was er toen nog); N. Mac Leod: De Oost-Indische Compagnie als zeemogendheid in Azië, dl. I (Rijswijk 1927) p. 15; „Discours ende advertentie", genoemd op p. 10, noot 3; Wieder III 36 (die hier blijkbaar De Jonge gevolgd heeft). 
barnevelt, was opgericht. Dit waren de Erasmus en de Nassau, welke met de eerste Compagniesvloot onder $W^{i j b r a n d ~ v a n ~ W a r w i j c k ~ w a r e n ~}$ uitgevaren. 6 Juni 1603 zond de admiraal deze beide schepen naar China ${ }^{1}$ ), zonder dat het plan was, dat ze Patani zouden aandoen. Toch werd, tegen de oorspronkelijke bedoeling, genoemde plaats bezocht, waarschijnlijk ter wille van proviandeering voor de verdere reis. We vernemen althans, dat de schepen in Juli 1603 korten tijd ${ }^{2}$ ) voor Patani hebben gelegen om verversching en rijst op te doen, en dat ze aldaar voor de verdere reis een Chineeschen loods in dienst namen, waarna de tocht naar China voortgezet werd ${ }^{3}$ ).

In de organisatie van hestuur en handel der Nederlanders in Patani konden deze Compagniesschepen, die immers geen last hadden gehad, deze plaats aan te doen, natuurlijk nog geen wijziging aanbrengen. Spoedig echter zou Van Warwijck's vloot zich in dit opzicht op ingrijpende wijze doen gelden. Hoe dit geschiedde, zal in het volgende hoofdstuk worden meegedeeld.

Dat Patani in den tijd der voorcompagnieën en ook nog vlak na de stichting der Oostindische Compagnie als een der veelbelovendste handelspunten werd beschouwd, kunnen we des te beter begrijpen, als we het oordeel lezen van twee mannen, die in 't vaderland ongetwijfeld groote autoriteit genoten, namelijk Van Neck en Heemskerck. Men had, zoo verklaart de eerste ${ }^{4}$ ), ons gewaarschuwd tegen bedrieglijkheid der Pataniërs, maar ,ick achte dat de Hollantse nacie in Oostindien noyt plaetse bevaren heeft, daer sy beleefder en oprechter getracteert is geweest als wy in deese stat”. Patani zou „de bequaemste plaetse van Oost Indien" zijn om met allerlei Oostersche volken te handelen, als maar de Nederlandsche koopmanschappen er meer "getrocken" waren. Heemskerck zegt van Patani, dat het ,de beste plaetse is, daer ic in Oost-Indien geweest ben", en verder, dat

1) Toen daarna Heemskerck met zijn boven vermelde kraak in Bantam aankwam, bleek het, dat zich daarin veel geheime instructies bevonden, op den Chineeschen handel betrekking hebbende, reden, waarom de admiraal een drietal jonken met copieën hiervan uitzond om de reeds uitgevaren schepen daarmee te gerieven.

2) Waarsch. 1-11 Juli. Cornelis Claesz (zie noot 1 p. 13) geeft: 10-11 Juli, maar dit lijkt, met 't oog op 't proviandeeren, wel wat te kort.

3) Vgl. over de Erasmus en de Nassau: Purchas His Pilgrimes (Glasgow 1905-1907) V 216; Begin ende Voortgangh I: Cornelis Claesz p. 30, verhaal van Cornelis van Veen p. 26, en reis Warwijck p. 2, 30, 45, 54, 72; De Jonge III p. 21; Tiele Eur. 4 VI p. 221; Groeneveldt p. 11, 14.

4) Arthus p. 35 ; het reisverhaal van Van Neck. 
hij er ,seer groote. vrientschap" geniet ${ }^{1}$ ). Elders ${ }^{2}$ ) noemt hij Patani „,wel de seeckerste van alle de peeper pladtsen ende daer het silver best in waerden can ghehouden worden"...., ,wij hebben in Petani oock ghevonden ververstandigher ${ }^{3}$ ) regheerders als op andere pladtsen". Alleen merkt hij als bezwaar op, dat Patani „wadt varde ${ }^{4}$ ) achter de handt leydt".

Het loont de moeite, na te gaan, in hoe verre de Nederlandsche belangstelling voor Patani nog anders is vast te stellen dan alleen door het feit, dat er in korten tijd niet minder dan drie loges gesticht werden. Een paar gegevens staan ons hiervoor ten dienste in den vorm van lijsten van goederen en contanten, welke door Van Neck en Heemskerck werden achtergelaten. Hieruit blijkt, dat het totale ,cargasoen”, door Van Neck geleverd, f $44861.2 .6^{5}$ ) bedroeg, waaronder aan contanten 16048 realen van achten, waard zijnde $f 36108$. Heemskerck heeft uit de Alkmaar en de Witte Leeuw geen contanten achtergelaten, maar daarentegen veel meer koopmanschappen dan Van Neck, namelijk aan geprijsde artikelen f 23576.10.8, waarbij nog 78159 pond sandelhout, waarvan geen prijs genoemd staat.

Beschouwen we nu den aard der aan land gelaten goederen nader, dan blijkt ons ten opzichte van Van Neck, al is 't hierop betrekking hebbende stuk hier en daar onleesbaar, dat meer dan de helft van 't door hem aangebrachte bestond uit geweven stoffen, aan lakenen minstens $f$ 4054.7.8 ${ }^{6}$ ), en aan andere stoffen $f$ 1154.6.-. Van de andere artikelen noemen we spiegels, messen, scharen en vijlen, maar vooral, als curiosum, een post ,boeken kunst”, zijnde Hollandsche prenten, waarop reeds IJzerman in 1926 de aandacht gevestigd heeft ${ }^{7}$ ). De 5 à 6000 prenten, de meeste zonder opgave der graveurs ${ }^{8}$ ), bieden een rijke verscheidenheid van onderwerpen. In de eerste plaats is de Bijbelsche geschiedenis er vertegenwoordigd, zoo: „11 blaren van Susanna”, „15 blaren van de Samarijtaen” 9), „20

1) De Jonge II bij1. XXIX.

2) Heemskerck aan Beww., Bantam 27 Aug. 1603, Loketkast S.-G., afd. Processen.

3) Misschien in 2 woorden bedoeld als : verreweg verstandiger.

4) Ver.

5) Op de guldens volgen dus de stuivers $(20$ st. $=\mathrm{f} 1)$, op de stuivers de penningen (16 penn. $=1$ st.).

6) Hier komt waarschijnlijk nog een kleine f $400 \mathrm{bij}$.

7) IJzerman p. 96 v.

8) De wel vermelde namen zijn die van Jac. de Gheyn, Hendrick Goltzins, Harmen Muller, Jan Harmensz. Muller en Pieter Breughel.

9) Dit onderwerp komt nog eens voor. 
blaren van de Babelonisen toren”, „107 blaren van het cranck geloof van Petrus"; Renaissance-invloeden verklaren het groote aantal prenten, dat op de klassieke oudheid betrekking heeft, zooals „28 boeken van de Romse keijsers”, „8 boeken van 3 godinne”, „,3 blaren van Serus ende Bachus”, „41 blaren van Cleopatra”, „17 boeck van de Roemsche helten"; den invloed der rederijkers treft men an in zinnebeeldige voorstellingen als „3 boecken van de 7 deuchden”, „10 boeken van de 5 sinnen" 1 ), „,6 boecken van 4 elementen". We vinden een aantal portretten als ,20 blaren van de prins ${ }^{2}$ ) ende hartich Matheus" ${ }^{3}$ ) en "1 boeck van de hartogen van Brabant”. Ook over landschappen, bedrijf, legermacht vinden we prenten, b.v. „36 blaren lantschappen” $\left.{ }^{4}\right)$, „36 blaren van lantbouwerije”, „92 blaren van de voegelaers”, „16 blaren van jachten”, „12 boeken van schatterije”, „4 boeken ruijterije". Groot is ook het aantal amusementsprenten: we vinden "60 blaren van boere bruijloften”, „44 blaren van quade wijven”, „20 blaren van de dubbelde sotten”, „12 blaren van gecken in de mou”, „45 blaren van een vrier tusschen 2 vristers”, terwijl onderwerpen als ,van bordeelen”, ,.... . vrouwen in 't overspel”, „,van de tuijn der wellusticheijt", ,de vrou trekt de man te bedde" aantoonen, dat onze Calvinistische landgenooten allerminst van plan waren, tegenover de inwoners van Patani als zedelijkheidsapostels'op te treden. De boekwaarde der prenten was zeer verschillend en varieerde van $1 / 2$ tot 10 stuivers per stuk.

Van de handelswaren, door Heemskerck aangebracht, vallen te noemen, behalve het reeds bovengenoemde sandelhout, voor $f$. 6967.9.11 aan lakens, voor f 2123.0 .12 aan andere weefsels. Ook tref ik an f 3958.12.14 aan lood. Verder is opvallend de groote en zeer gevarieerde hoeveelheid glaswerk, samen ten bedrage van meer dan f $\left.2560.11 .0^{5}\right)$. Dit is ten deele van Boheemsche herkomst, ten deele ook uit Danzig. We vinden bij dit glaswerk een groote verscheidenheid: wijnglazen, „,cruijtstanders" ${ }^{8}$ ), ,,ampuletten" ${ }^{7}$ ), ,gemaelde cannekens met litten" ${ }^{8}$ ), „Dansiker flessen met gegooten schroeven”,

1) Dit onderwerp komt nog eens voor.

2) Prins Willem I.

3) Hertog Matthias.

4) Platen over landschappen vinden we nog driemaal elders bij deze verzameling.

5) $\mathrm{Er}$ is namelijk waarschijnlijk nog $\mathrm{f}$ 64.6.- voor een niet uitdrukkelijk als glaswerk genoemden post. Merkwaardig is ' $t$, dat ik eenmaal onder 't glaswerk aantref : witte steenen kannen!

6) Bloemenvazen?

7) Amplet: kegelvormig medicijnfleschje.

8) Deksels. 
„geijsde bierbeekers met gheijsde landen" ${ }^{1}$ ), „olijfleskens” enz. Groot is ook het aantal aan land gebrachte spiegels (voor $\mathrm{f}$ 1591.17.8), waaronder de Venetiaansche opvallend zijn. Aan staal en ijzer werd voor f 1313.9.0 achtergelaten.

Hiermee is echter het in Patani gelaten cargasoen nog geenszins volledig aangeduid; een lange reeks van andere artikelen staat nog vermeld, als kompassen, garen, knoopen, papier, tin; verder ook allerlei "Noorenburgery”, als scharen, brillen en briletui's, vijlen, beitels enz. ${ }^{2}$ ).

1) Bierglazen met landschappen in matglastint er op?

2) Zie over de door Van Neck en Heemskerck aangebrachte waren : Copiefactuur van de goederen, gelaten in Patani door Van Neck onder Daniël van der Leck en Pieter Walichsz., Patani, 22 Aug. 1602; kopie-factuur der koopmanschappen, overgeleverd door Heemskerck aan Daniël van der Leck en Pieter Walichsz., Patani, 16 Sept. 1602; kopie-factuur van de levering van lood enz. door Heemskerck aan Daniël van der Leck en Pieter Walichsz., Patani, 30 Sept. 1602. 


\section{TWEEDE HOOFDSTUK.}

\section{De Nederlanders in Patani tijdens de Oostindische Compagnie.}

\section{a. Tot den dood van Ferdinand Michiels (1603-1607).}

De eerste vloot van de Oostindische Compagnie, die van Van Warwijck, bracht, we zeiden het reeds $^{1}$ ), voor Patani de noodige eenheid. Dit gebeurde niet door den admiraal zelf, maar door diens onderbevelhebber Cornelis Pietersz. van Enkhuizen, die als zoodanig wederom de opvolger was van den op Ceilon zoo verraderlijk vermoorden Sebald de Weert ${ }^{2}$ ). 24 Augustus 1603 vertrok Cornelis Pietersz. uit Atjeh met de schepen Zierikzee, Hollandsche Tuin en het jacht het Papegaaiken, met bestemming naar Patani. Onderweg verschenen de schepen voor de haven van Johor ${ }^{3}$ ), waar het kleine Nederlandsche smaldeel er toe medewerkte, het ontzag voor de onzen bij de inlanders te vestigen, door een Portugeesche vloot te verslaan, die de rivier van Johor bezet hield. Hoewel de sultan van Johor trachtte, Cornelis Pietersz. met zijn schepen nog een tijdlang bij zich te houden, waarschijnlijk wel uit vrees voor represaillemaatregelen van den vijand, ging de vice-admiraal hier niet op in; hij zond het jacht naar Bantam, en zette zelf op 14 October zijn reis naar Patani voort. Den $4^{\text {en }}$ November kwamen de schepen eindelijk hier voor anker, waarna Cornelis Pietersz., door een aantal tochtgenooten begeleid, onder 't afvuren van ,alle de groove stucken van beyde de schepen" naar land voer; hierop werd eerst een bezoek gebracht ten huize van den rentmeester Dato Sirinara, en daarna aan de koningin. Aan 't hof trof men ook den sabandar aan met nog een aantal andere aanzienlijke heeren, die naarstig vroegen naar bijzonderheden omtrent 't voor Johor op de Portugeezen behaalde succes. De koningin zelf, die bij 't bezoek der Hollanders slapende

1) Zie p. 14.

2) De Jonge III, p. 13.

3) ,anders ghenaemt, den haven van Patana", staat ten onrechte in 't reisverhaal-Van Warwijck (Begin ende Voortg. I), p. 38. 
werd gevonden, ,alsoo bethel geknaut ende taback gedroncken hadde”, werd na haar ontwaken met de komst van Cornelis Pietersz. op de hoogte gebracht; ze liet hem weten, dat ze hierover zeer voldaan was; de Hollanders werden op bananen onthaald, ,ondertusschen bliessen de trompetters ettelijcke reysen, daer de heeren groot vermaeck in namen". Hierop volgde nog een bezoek ten huize van den sabandar, die, evenals de koningin en Dato Sirinara, met geschenken vereerd werd, en ten slotte werd de rest van den dag en de daaropvolgende nacht doorgebracht in de Nederlandsche loge ${ }^{1}$ ).

Was aldus de ontvangst, die de Nederlanders genoten, ook nu weer uiterst vriendelijk, spoedig zou blijken, dat de zaken minder vlot gingen, zoodra het op reëele voordeelen aankwam; begeerigheid naar verdere geschenken en groote stugheid en stroefheid bij de onderhandelingen over den peperinkoop, dat zijn de trekken, welke bij 't bezoek van Cornelis Pietersz. naar voren komen. In de eerste plaats bleek de hoeveelheid peper, die van de inlanders kon worden betrokken, kleiner, dan in uitzicht gesteld was; verder werd een te hooge prijs gevraagd (35 realen van achten per baar), waarbij dan nog zouden komen $5 \%$ tolgeld, een waaggeld van een maes ${ }^{2}$ ) per baar en voorts nog een vereering voor de lading. Bijzondere ergernis wekte het nog bij de Hollanders, dat zij de peper niet gezuiverd konden krijgen, maar ook alle afval, dat ze niet in de'schepen meenamen, mee moesten betalen. Geschenken, aan verschillende inlanders vereerd, konden hierin geen verandering brengen. Gelukkig was Cornelis Pietersz. bij den peperinkoop niet alleen afhankelijk van de inlanders. Op twee manieren kon de lading nog worden aangevuld. 16 November kwamen namelijk Van Groesbergen en Van der Leck bij den vice-admiraal aan boord om te onderhandelen over verkoop van de peper, welke het schip Haarlem ${ }^{3}$ ) nog aan boord had. Twee dagen later werd men 't eens, en na teekening van het desbetreffend koopcontract op den $22^{\text {en }}$ begon dadelijk de lossing van de Haarlem. Verder gèlukte het Cornelis Pietersz., nog een hoeveelheid peper van de Zeeuwen te koopen. Aldus vertrok hij zelf met het volladen schip Zierikzee op 20 December 1603 naar Bantam ${ }^{4}$ ); de Hollandsche Tuin bleef nog

1) Het is niet duidelijk, of hier de door Van Neck of de door Heemskerck gestichte loge bedoeld wordt.

2) $2 / 3$ reaal.

3) Vgl. p. 13.

4) Tiele Eur., 4 VI, p. 218, geeft hier ten onrechte: 21 April 1604. 
achter om zijn volle lading te verkrijgen ${ }^{1}$ ), en volgde de Zierikzee in den nacht van 8 op 9 Februari 1604. De Haarlem was inmiddels op last van Van der Leck achter de Hollandsche loge ${ }^{2}$ ) gebracht en daar in brand gestoken.

Mocht Patani op dezen tocht de verwachting der bezoekers teleurgesteld hebben, het pleit voor de groote energie onzer voorouders in dien tijd, dat, terwijl nog het schip Hollandsche Tuin er ter reede lag, een aantal Nederlanders, onder leiding van Van der Leck, in een jonk naar Siam trok onder begeleiding van een aantal inwoners van dit land, dat groote winsten scheen te zullen afwerpen, daar het rijst opleverde, verder roggevellen en, wat 't meest van beteekenis was, hertevellen, die in Japan zeer gewild waren.

Wij zullen echter later gelegenheid hebben, op de Nederlandsche betrekkingen met Siam terug te komen, en willen nu eerst 't punt van centralisatie in Patani bespreken, het stichten van een algemeene Compagnie's loge door Cornelis Pietersz. Temidden van de moeilijke onderhandelingen over den peperinkoop was dit punt op 14 November 1603 ter sprake gebracht tegenover de inlanders, nadat er een groot aantal geschenken was uitgedeeld. Een geschikt, reeds bestaand huis, dat op het terrein van den sabandar gelegen was, werd den onzen ontzegd, omdat hij er tegen was, ,dat sy op sijn goedt soude woonen”. De Nederlanders kregen echter de beschikking over een andere plaats, waar ze een huis mochten bouwen, en dadelijk begon men met het timmeren daarvan. Dit nu werd de eigenlijke Compagnie's loge. Daniël van der Leck kwam aan 't hoofd hiervan te staan, en er werden nog vier andere personen bij hem achtergelaten.

Het zou evenwel nog langen tijd duren, vóór de rekeningen van de Oude Compagnie, die dus, welke Van Neck had uitgezonden, en de eerste vereenigde Compagnie te Amsterdam, in wier dienst Heemskerck Patani bezocht had, geheel vereffend zouden zijn, doordat nog steeds onverkochte goederen daarvan in Patani bleven. Nog in September en October van 1608 vinden we dezen toestand bestendigd. Den $25^{\text {en }}$ van eerstgenoemde maand schrijft Victor Sprinckel, die dan de Compagnie's loge te Patani bestuurt, aan Jacques l'Hermite te Bantam, dat hij hoopt, de zaken van de oude en de vereenigde Compagnie van Amsterdam in 't jaar 1609 voorgoed te liquideeren. En uit een schrijven van den zelfden Sprinckel

1) MacLeod I geeft op p. 15 den onjuisten indruk, dat de peper uit de Haarlem uitsluitend in de Hollandsche Tuin geladen werd.

2) Hiervoor geldt de opmerking van p. 19 noot 1 . 
d.d. 31 October 1610 aan bewindhebbers van de kamer van Delft leeren we, dat dan inderdaad alles of vrijwel alles, wat er van de oude compagnie van Amsterdam ${ }^{1}$ ) zich nog in Patani bevond, reeds is verkocht. Ruim een jaar later is door Heeren XVII besloten, dat aan de Compagnie van de 14 schepen (hiermee is bedoeld de onderneming van Van Warwijck) zal betaald worden voor de huizen en loges van Patani en Grissee, ,ten aensiene deselve van cleender importantie zyn", de som van 300 realen van achten. Over de eindafrekening van de Zeeuwsche Compagnie heb ik geen gegevens ${ }^{2}$ ).

Spoedig na het vertrek van Cornelis Pietersz. werd Patani door diens admiraal, Van Warwijck, persoonlijk bezocht. Op een tocht naar China, het voor de Compagnie steeds zoo aanlokkelijke handelsgebied, verscheen deze op 3 Mei 1604 voor Johor met de schepen Hollandia en Vlissingen en de boot Sphera Mundi ${ }^{3}$ ). Van den opperkoopman aldaar, Jacob Buysen, vernam hij tot zijn grooten spijt, dat de vice-admiraal reeds uit Patani naar Bantam was vertrokken; zijn plan, van dezen zooveel mogelijk contanten voor de reis naar China over te nemen, leed daardoor schipbreuk. Hij zond daarom de Sphera Mundi naar Bantam, om alsnog van Cornelis Pietersz. een voldoende som in handen te krijgen en hem die dan in China te brengen. 20 Mei verliet Van Warwijck Johor; tien dagen later kwam hij in Patani aan. Zijn doel was daar uitsluitend, tolken en loodsen voor den verderen tocht aan hoord te nemen. Het kostte evenwel moeite, daarvoor de geschikte personen te vinden. Wel scheen zich een mooie gelegenheid aan te bieden om middellijk aan 't Chineesche hof invloed te krijgen. Uit Borneo kwam in deze dagen namelijk een gezant van den koning van Siam in Patani, die verklaarde, dat binnenkort

1) Dit zal hier wel een samenvattende term zijn voor de Oude Compagnie en de eerste vereenigde Compagnie te Amsterdam.

2) Vgl. over den tocht van de Zierikzee en De Hollandsche Tuin naar Patani: 't verhaal van den tocht van Warwijck in B. ende Voortg., p. 32 v. en 38 v.; Mr. L. C. D. van Dijk: Iets over onze vroegste betrekkingen met Japan (Amsterdam 1858), p. 15; De Jonge III, p. 15 v. en 19; Tiele, Eur. 4 VI, p. 180 noot 5 en p. 216 v.; Dr. H. P. N. Muller: Het land van den Witten Olifant en de factorijen van de Compragnie aldaar, in Vragen des Tijds, 1912, I, p. 137; 't Overzicht, genoemd op p. 7 noot 2, p. 412; Wieder, III, p. 36; MacLeod I, p. 14 v.; Copie-brief van Victor Sprinckel aan Jacques l'Hermite te Bantam, Patani 25 September 1608, Copieboek Victor Sprinckel; Victor Sprinckel aan beww. te Amst., Patani 25 Sept. 1608; Victor Sprinckel aan Jacques l'Hermite de Jonge te Bantam, Patani, 27 Oct. 1608; Copie-brief van Victor Sprinckel aan beww. kamer Delft, Patani 31 Oct. 1610; Copie-ress. Both en zijn raad, 20 Dec. 1610-13 Juli 1611.

3) I.p.v. de Sphera Mundi noemt MacLeod (p. 15) ten onrechte de Maene. 
een Siameesch gezantschap naar China zou vertrekken (naar 't schijnt werd ieder jaar een dergelijk gezantschap afgevaardigd), en dat een bekwaam vertegenwoordiger van de Compagnie, in gezelschap van dit gezantschap vertrekkende, goede kansen op 't aanknoopen van handelsbetrekkingen zou hebben. Van Warwijck, die alle middelen, welke tot het doel konden leiden, aangreep, zond nu Cornelis Specx ${ }^{1}$ ) met den gezant mee, aan wien hij o.a. nog zijn neef Lambert Jacobsz. Heyn toevoegde. 9 Juni vertrok Specx naar Siam. Hij zou eerst in 1607 terugkomen.

Wat zijn eigen tocht naar China betreft, Van Warwijck vond eindelijk een Chinees, Empo genaamd, bereid, hem te vergezellen, welke in dienst van de Zeeuwsche compagnie gestaan had. Bij 't slagen van de expeditie zou Empo niet minder dan 2000 realen ontvangen, terwijl men daarenboven nog te beloonen had een stuurman, een schrijver en twee andere Chineezen, die mee zouden gaan. Een aanbevelingsbrief van den rentmeester Sirinara aan den mandarijn van Sineau ${ }^{2}$ ) werd met een inlandschen schipper vooruitgezonden. De bezetting der beide schepen van den admiraal werd nog versterkt door een achttal Nederlanders, die tijdens zijn aanwezigheid te Patani aldaar met een jonk werden aangebracht door een gezant des konings van Broenei. Genoemde Nederlanders hadden behoord tot het volk van admiraal Jacob van Heemskerck; ze waren, toen ze zich ongewapend in een schuit bevonden, door eenige inwoners van Borneo overvallen en gevangen genomen. De koning van Broenei liet nu verklaren, dat dit indertijd tegen zijn zin was geschied, en bood aan Van Warwijck den vrijen handel in zijn rijk aan. Inderdaad is Patani voor onzen handel op Borneo van eenige beteekenis geworden.

Toen nu de admiraal met alle voorbereidende maatregelen gereed was, en ook de noodige verversching had ingeladen, ging hij 27 Juni des nachts met zijn schepen zeil naar China. Weliswaar had hij 't geluk, dat de Sphera Mundi daar bij hem kwam, maar de handel slaagde er niet naar wensch; eenige hoop kon 't echter geven, dat hem in 't vooruitzicht werd gesteld, dat de Chineesche handelaars binnenkort met hun waren in Patani zouden komen ${ }^{3}$ ). Daarheen

1) Groeneveldt (p. 16) spreckt ten onrechte van Jacob Specx.

2) Dit zal wel Chinchao (= Tsuentschou in de provincie Fokien) moeten zijn. Vgl. Muller: Onze vaderen in China, Gids 1917, I, p. 325.

3) Vgl. over 't voorgaande: tocht Warwijck in B. en V., p. 71 v.; Valentyn, III IIc, p. 90; Mr. L. C. D. van Dijk: Neêrland's vroegste betrekkingen met Borneo, den Solo-Archipel, Cambodja, Siam en Cochin-China, Amst. 1862, p. 211 v.; De Jonge III, p. 24; Tiele, Eur. 4 VI, p. 220 v., 4 VIII, p. 78 noot 3; 
besloot de admiraal dan ook, wederom te vertrekken. 15 December 1604 verliet hij China; den. $31^{\text {en }}$ van dezelfde maand bereikte hij Poeloe Condor, bij de kust van Cochinchina. $W_{i j}$ zien hem hierna met een zekere sluwheid te werk gaan: een spoedig doorvaren naar Patani, zoo redeneerde hij, zou commercieele nadeelen met zich kunnen meebrengen: de peperprijs zou, indien hij zich al te vlug weer aan de kust vertoonde, kunnen stijgen; verder zou hij dan allicht de beloofde Chineesche jonken vóór zijn, zoodat dan de Chineezen het besef zouden krijgen, dat er reeds reikhalzend naar hun waren werd uitgezien, en aldus ook voor de zijde licht een te hoogen prijs zouden eischen. Daarom werd besloten, opzettelijk nog een tijd te traineeren, echter zoo, dat de minder belangrijke boot Sphera Mundi alvast vooruitgezonden werd met een cargasoen van 54000 realen van achten. Hiervan moest Jacques Roussel ${ }^{1}$ ), van de Zeeuwsche compagnie, die voor den handel op China met Van Warwijck gemeene zaak gemaakt had, er 9800 terugontvangen, waarop later nog 200, na aftrek van de gemaakte onkosten, zouden volgen. Het kantoor Patani zou, tegen de komst der jonken, peper en andere waren, in China dienstig, moeten opkoopen. Met de Sphera Mundi gingen ook de Chineezen terug, die door Warwijck in dienst waren genomen; ze werden ontslagen, behalve Empo, die door den admiraal zoodanig gewaardeerd werd, dat hij order kreeg, bij de komst der jonken te Patani er zorg voor te dragen, dat geen fraaie en kostbare kleinigheden door anderen dan de Nederlanders zouden worden opgekocht ${ }^{2}$ ). 3 Januari voer de Sphera Mundi, na genoemde opdrachten te hebben ontvangen, van de andere schepen weg.

Bij Poeloe Tioeman ${ }^{3}$ ), dicht bij Johor gelegen, zond Warwijck, volgens een van te voren gemaakt plan, de Vlissingen naar Bantam vooruit met zijde, die hij te Johor en in China gekocht had; in Bantam moest de Vlissingen lading innemen en dan naar 't vaderland ver-

Groeneveldt, p. 15 v.; Muller: Onze Vaderen in China, Gids 1917 I, p. 323; Wieder III, p. 36; Copie-brief van Victor Sprinckel aan Jacques 1'Hermite te Bantam, 25 Sept. 1608, Copieboek V. S.; Victor Sprinckel aan beww. te Amst., Patani, 25 Sept. 1608.

1) Vgl. p. 9 noot 4.

2) Empo is verder voor de Compagnie een tijdlang een belangrijk persoon gebleven; we vernemen, dat hij met Van Warwijck in Holland is geweest (Extract-brief van Abraham van den Broecke, Patani, 15 Oct. 1612 vanaf zijn aankomst te Bantam op 2 Febr. 1612), en dat hij in 1612 Christen is (brief van hem aan beww. v. Holl. en Zeel., Patani, 15 Oct. 1612). Vgl. verder over hem hoofdstuk III.

3) De Jonge III, p. 24, zegt ten onrechte, dat dit geschiedde bij de kust van Tsi-ampa. 
trekken. Den $24^{\text {en }}$ Februari kreeg men de Sphera Mundi weer te zien, welke proviand aan Warwijck bracht, en hem inlichtingen deed toekomen aangaande de zending van Specx naar China ${ }^{1}$ ). Deze had van Siam uit om meerderen financieelen steun voor zijn reis geschreven, die nu volgens zijn meening stellig zou doorgaan; het kantoor Patani had hem daarop nog 2000 realen van achten toegezonden. Warwijck was echter hierover allesbehalve tevreden: zijn bedoeling was alleen geweest, dat Specx als dienaar van den ambassadeur des konings van Siam mee zou gaan, en niet als zelfstandig gezant. Zou hij als zoodanig gaan, dan zou hij zooveel aan geschenken moeten geven, dat de 2000 realen nog bij lange na niet genoeg zouden zijn.

Den $25^{\text {en }}$ Maart in de nabijheid van Patani gekomen zijnde, vaardigde Warwijck een prauw naar deze plaats af om te polsen, of zijn komst op dien tijd gewenscht was. Den volgenden dag kwam de prauw terug met opzienbarend nieuws: den $17^{\text {en }}$ Februari was een Portugeesche kraak, S. Antoni genaamd, van Macao komende zonder roer voor Patani aangekomen. Blijkbaar hoopten de opvarenden op de bescherming, welke ze zouden genieten van de koningin van Patani; de Nederlanders echter, onder aanvoering van Claes Simonsz. Meebael, welke blijkbaar sedert 't vertrek van Van der Leck naar Siam ${ }^{2}$ ) aan 't hoofd van de zaken stond, hadden zich tot de koningin en haar raden gewend met 't dringend verzoek, de kraak te mogen aantasten en bezet te houden, 't welk hun oogluikend toegestaan was. Op dit bericht haastte Warwijck zich naar Patani, waar hij op 26 Maart ter reede kwam, en dicht bij de kraak het anker liet vallen. De Portugeezen beloofden het schip te zullen ontruimen ,behoudens hunne lijven"; nog dienzelfden avond werden ze alle aan land gezet. Het grootste deel van de lading hadden de Portugeezen echter voor dien tijd al aan land weten te brengen; toch behaalde men nog een belangrijke buit, bestaande uit zijde, geweven stoffen, suiker, ,tintinage” ${ }^{3}$ ), kamfer, ,aguelae” ${ }^{4}$ ), muscus, vermiljoen, Chineesche waaiers, porselein, vergulde bedsteden, radix $\mathrm{China}^{5}$ ), benzoë, gouddraad en eenige kleinigheden, die niet nader genoemd worden.

\footnotetext{
1) Zie p. 21-22.

2) Zie p. 20.

3) Zink uit China. Vgl. Van Dam I II glossarium s.v. tintemago.

4) Aguilhout, hout van den aloë-boom (Van Dam II I gloss. s.v. aguila). Zie hoofdstuk III.

5) Radix Chinae: gedroogde wortel met medicinale kracht. Zie hoofdstuk III.
} 
Van de koningin kocht Warwijck voorts 408 picol ${ }^{1}$ ) ruwe zijde voor \pm 115 realen van achten per picol, daarin begrepen tol en waaggeld, welke zijde ook uit de kraak afkomstig en door de koningin in beslag genomen was, verder van particulieren nog \pm 22 picol ruwe en voor \pm 3000 realen van achten gewrochte zijde, eveneens, naar 't mij schijnt, uit den S. Antoni afkomstig.

De Nederlanders moesten nu bedacht zijn op wraakpogingen van de Portugeezen: er was sprake van de komst van een armada uit Malakka, die het schip zou komen ontzetten, daar 't aan den gouverneur Don Andrea Furtado behoorde. Daarom werd zoo spoedig mogelijk de kraak wat verbouwd en verder van een bemanning voorzien, die haar moest verdedigen en naar 't vaderland voeren.

Maar niet slechts de Nederlanders moesten op hun hoede zijn, ook de koningin van Patani en haar raden gaven hoog op van de gevaren, waaraan ze nu, wegens hun aan onze landgenooten betoonde goedgunstigheid, blootstonden, gevaren, die volgens hen 't recht op een belangrijke compensatie van Nederlandschen kant meebrachten. De onzen lieten zich vinden: na veel gehaspel werd 't bedrag van de schadeloosstelling bepaald op 12000 realen van achten, ,daer nevens noch loopende eenighe kleyne schenckagien van zijde wercken". Verder werden nog 2640 realen van achten geëischt voor een jonk van ,een groot Meester van Patane”, Radzia ${ }^{2}$ ) Calanta genaamd, die in Malakka was aangetast en verbeurd verklaard; men werd 't eens voor 1500 realen. En hiermee werd verklaard, dat alle schade, die de Pataniërs van de Portugeezen zouden komen te lijden, ,doodt ende te niet" zou zijn. Warwijck kon het als een groot succes beschouwen, dat door de genoemde gebeurtenissen de Pataniërs openlijk partij gekozen hadden tegen de Portugeezen, en daardoor ook voor de toekomst des te veiliger bondgenooten voor ons zouden zijn. De Portugeezen zonnen nu op wraak. Ze kochten een aantal Japanners er toe om, Patani te overvallen, maar dezen voelden zich begrijpelijkerwijze bij nader inzien daartoe te zwak. Daarop staken ze de voorstad in brand, bij welke gelegenheid weliswaar de Nederlandsche loge gespaard bleef, maar een partij van \pm 200 picol zijde, welke Warwijck anders ook nog had kunnen koopen, door de vlammen vernietigd werd.

Omstreeks dezen tijd kwam onverwacht het schip Vlissingen, na in Bantam zijn lading gelost te hebben, weder voor Patani ter reede.

1) Picol: \pm 120 pond.

2) Is natuurlijk het woord radja. 
Het had in verschillende wapenfeiten tegen de Portugeezen succes gehad, waarop na zijn terugkomst in Patani nog volgde het nemen op 16 Juni van een Portugeesch scheepje uit Solor ${ }^{1}$ ), dat voornamelijk met sandelhout geladen was ${ }^{2}$ ).

15 September zond nu Warwijck de Vlissingen met de kraak S. Antoni vooruit naar Johor, om lading te zoeken; zelf zou hij, als hij de zaken in Patani ten volle afgedaan had, met de Hollandia volgen. De voornaamste daad, welke hieronder valt, was het aanstellen van een nieuw hoofd over de loge van Patani, namelijk Ferdinand Michiels, die als opperkoopman 72200 realen van achten en eenige koopmanschappen kreeg om den handel verder te behartigen. Meebael heeft dus blijkbaar maar kort de leiding der zaken in handen gehad; wat Van der Leck betreft, die als de eigenlijke beginner van den Compagnie's handel kan worden beschouwd, deze was blijkbaar van zijn zending naar Siam reeds weer teruggekeerd; hij is althans met admiraal Warwijck uit Patani vertrokken ${ }^{3}$ ).

Dit geschiedde op 27 October. Warwijck kwam 12 November op de rivier van Johor, vertrok vandaar op 12 December, en verscheen den $27^{\text {en }}$ van deze maand op de reede van Bantam.

Daar ontving hij bericht van Cornelis Specx uit Siam, waaruit hem bleek, dat in 1605 geen gezantschap naar China vertrokken was ${ }^{4}$ ), dat de koning van Siam was gestorven en opgevolgd door zijn broer, en dat in 1606 stellig wel een gezantschap zou vertrekken. Warwijck zag evenwel tegen de onkosten op, en trachtte Cornelis Bastiaensz., vice-admiraal van de vloot van Van der Hagen, ervoor te winnen, Specx in dienst van de ,groote compagnie" te nemen ${ }^{5}$ ). Bastiaensz. weigerde echter hierop in te gaan, waarop Specx, wiens zending aanvankelijk zooveel goede verwachtingen had opgewekt, naar Patani terug ontboden werd. Hij schijnt echter zijn verblijf in Siam nog te hebben gerekt, want eerst in 1607 kwam hij in Patani

1) Journaal van Paulus van Solt (onderdeel van den tocht van Van der Hagen, Beg. ende Voortg. II), p. 42, zegt, waarschijnlijk ten onrechte: Timor.

2) De Jonge III, p. 25, stelt ten onrechte het nemen van dit scheepje vóór de terugkomst van de Vlissingen in Patani.

3) Op zijn terugreis naar patria heeft Van der Leck nog het oppergezag over een paar schepen gevoerd.

4) De Jonge III, p. 25, zegt, dat Warwijck reeds vóór zijn aankomst in Patani in 1605 bericht kreeg, dat de voorgenomen reis van Specx naar China niet had plaats gehad. Dit moet onjuist zijn.

5) Dit slaat op 't feit, dat de tocht van Van Warwijck, hoewel op last van de V.O.I.C. ondernomen, nog een afzonderlijke financieele onderneming was (de z.g. 10-jarige rekening). 
aan $^{1}$ ), in gezelschap van Siameesche gezanten, die bestemd waren, de reis naar Nederland te doen ${ }^{2}$ ).

We noemden reeds Cornelis Bastiaensz., die als vice-admiraal van Steven van der Hagen naar Indië gevaren was. De vloot van Van der Hagen was de tweede, welke in dienst van de Oostindische Compagnie ons land verliet, en wel in December 1603. Meer nog dan die van Van Warwijck was zij bestemd om oorlog te voeren tegen „Spaniaerts, Portugysen ende hare adherenten" ${ }^{3}$ ), maar daarnaast moest toch ook, zooals te verwachten was, de handel zooveel mogelijk bevorderd worden. En hierbij zien we nu Patani zeldzaam op den voorgrond treden. Volgens de bedoeling der bewindhebbers zouden Patani en Bantam de twee belangrijkste steunpunten van den handel moeten zijn: beide zouden onder het gezag staan van een opperkoopman, bijgestaan door twaalf assistenten; voor beide plaatsen werd een predikant bestemd. Wat Patani betreft, Frederik de Houtman zou hier aan 't hoofd komen te staan; Johannes Stollenbeecker zou er als predikant heen gaan. Vier schepen, de Medemblik, Dordrecht, Amsterdam en Hoorn, zouden de factorij bezoeken en er een zeer aanzienlijk cargasoen aan land laten, te weten f 245000 aan geld, d.i. ongeveer ${ }^{1 / 3}$ van wat de geheele vloot mee $\mathrm{kreeg}^{4}$ ), en $\mathrm{f} 30000$ in koopmanschappen, dat is ook bijna $1 / 3^{5}$ ). Verder zou Patani het uitgangspunt moeten zijn voor een bezoek aan China, waarheen Jan van Artss, fiscaal over de vloot, met een credentiebrief van prins Maurits, als gezant werd afgevaardigd. In Patani moest hij echter met de factorijhouders nader overleg plegen over de wenschelijkheid

1) Het journaal van Warwijck (p. 84 v.) omtrent de terugkomst van Specx is onduidelijk.

2) Vgl. over het bovenstaande: Journaal Warwijck, p. 77 v.; het bovengenoemde journaal van Paulus van Solt, p. 42 v.; Purchas His Pilgrimes III, p. 491; Valentyn, $I^{\circ}$ deel, $I^{\mathrm{e}}$ stuk, $1^{\mathrm{e}}$ onderdeel, p. 192 v.; idem III IIc, p. 90 ; De Jonge III, p. 24 v.; Tiele Eur. 4 VI, p. 223, 238 v.; Mr. L. C. D. van Dijk: Zes jaren uit het leven van Wemmes van Berchem, Amsterdam 1858, p. 32, noot 3; Muller: Het land van den Witten Olifant, p. 135 v.; Groeneyeldt, p. 16; Muller: Onze Vaderen in China, Gids 1917 I, p. 323; Wieder IIf, p. 36 v.; MacLeod I, p. 15 v.; IJzerman, p. 94, noot 2; Copiebrief van Hendrik Janssen aan beww., Patani, 24 Sept. 1608, Copieboek Hendrik Janssen ; Copiebrief van Victor Sprinckel aan Jacques 1'Hermite te Bantam, Patani, 25 Sept. 1608, Copieboek V.S.; Empo aan beww. van Holland en Zeeland, Patani, 15 Oct. 1612; Copiebrief van J. P. Coen aan Hendrik Janssen, Bantam, 10 Juni 1615 (Colenbr. Coen II, p. 10 v.) ; Extract-brief van Abraham van den Broecke, bedoeld op p. 23 , noot 2 .

3) De Jonge III, p. 29.

4) f 738000 .

5) Met de heele vloot f 99300 . 
der ambassade, vooral over de vraag, of de kosten daarvoor niet te hoog zouden vallen. Alles dus gegevens, waaruit te voorspellen viel, dat door den tocht van Van der Hagen ons kantoor in Patani zeer in beteekenis zou toenemen. De uitvoering is echter ver beneden de plannen gebleven; Frederik de Houtman werd er geen opperkoopman ${ }^{1}$ ), van de aanstelling van Stollenbeecker hooren we verder niets, en Jan van Artss is niet als gezant naar China vertrokken. Meer positief te zeggen, wat er dan wel gebeurd is, is zeer moeilijk, daar hierover de gegevens schaarsch en ten deele tegenstrijdig zijn ${ }^{2}$ ). We kunnen intusschen enkele feiten vaststellen. Niet Van der Hagen zelf heeft Patani bezocht, maar, zooals we reeds zagen, zijn vice-admiraal Cornelis Bastiaensz. Deze vertrok voor dit bezoek 8 Juli 1605 uit de Molukken met de schepen Dordrecht, waarop hij zelf het bevel voerde, Amsterdam en Medemblik. Hij moet er bij zijn aankomst Warwijck nog hebben aangetroffen, heeft de Medemblik naar Bantam gezonden, in zijn eigen schip een groote hoeveelheid peper weten te laden, waarschijnlijk een iets kleinere lading in de Amsterdam, en vertrok, waarschijnlijk na Warwijck, naar Johor. Beide bevelhebbers hebben daar nog overleg gepleegd omtrent 't verleenen van steun aan den koning van Johor tegen de Portugeezen, en zijn toen samen of ongeveer gelijktijdig naar Bantam vertrokken. We zagen, dat Warwijck hier 27 December 1605 aankwam, volgens 't journaal over zijn tocht kwam Bastiaensz. een dag later ${ }^{3}$ ).

$\mathrm{Na}$ het bezoek van Cornelis Bastiaensz. komt er in 't Compagnie's kantoor van Patani een langdurige stilstand. Terwijl van eind 1601 tot en met 1605 deze plaats was bezocht door een verwarrend groot aantal Nederlandsche schepen, en de opvatting gerechtvaardigd was, dat daar voorgoed een levendige en winstgevende handel was ge-

1) $\mathrm{Hij}$ werd op 1 Maart 1605 tot gouverneur van Amboina aangesteld.

2) Vgl. over deze tegenstrijdigheid De Jonge III, p. 38, noot 1 en Tiele Eur. 4 VI, p. 239 , noot 1 .

3) Zie over de vloot van Van der Hagen in betrekking tot Patani : Journaal tocht Warwijck, p. 82 v.; Journaal Van der Haghen, p. 34 v. en 38; dat van Van Soldt, p. 42 v., p. 48; Valentyn I, I ${ }^{\mathrm{e}}$ stuk, $1^{\mathrm{e}}$ onderdeel, p. 192 v.; Van Dam II I, p. 324 v.; De Jonge III, p. 25 v., 30,37 v. en bijl. I A en II; Tiele Eur. 4 VI, p. 239 v.; Groeneveldt, p. 22 v.; MacLeod I, p. 17 en 19; Resolutie Heeren XVII in hun vergadering van 24 Oct. 1603; Instructie en ordonnantie voor admiraal Steven Verhagen c.s., 29 Oct. 1603 (gedrukt Bijdrr. en Medd. Hist. Gen. VI, p. 258 v.); Copie-brief van Hendrik Janssen aan Hendrik van Bergel, Patani, 29 Oct. 1607 (Copieboek H. J.); Copie-brief van Hendrik Janssen aan Frederik de Houtman op Ambon, Patani, 29 Oct. 1607 (Copieb. H. J.); Copie van het verzeilen van de vloot van Matelief (een andere, 19e-eeuwsche copie van dit stuk door De Jonge in Kol. aanw., No. 236). 
grondvest, duurde 't ongeveer twee jaren aaneen, voordat zich weer een Compagnie's schip op de reede vertoonde. Deze langdurige isoleering kon allerminst aangenaam zijn voor den leider der handelsbetrekkingen, Ferdinand Michiels; hij had echter voldoende kapitaal tot zijn beschikking om in ieder geval, in afwachting van de eerstvolgende schepen, ervoor te zorgen, dat hij een voldoende lading peper, zijde en andere eventueele koopmanschappen bijeen kreeg. Dit is echter niet geschied. Een der redenen van den slechten gang der handelszaken was stellig, dat de mandarijnen, de raadgevers der koningin, ook nu weer meer op hun eigen voordeel bedacht waren, dan voor een vlotten gang van zaken goed was: boven de gewone rechten eischten ze $11 / 2$ reaal van achten op iedere baar peper, en een som naar evenredigheid voor andere handelswaren. Maar Michiels schijnt ook niet de rechte man op de rechte plaats geweest te zijn: zijn opvolger, de ongetwijfeld bekwame en tot oordeelen bevoegde Hendrik Janssen, beschuldigt hem althans van te strak vasthouden aan zijn instructie bij de onderhandelingen : het zou, zoo zegt Janssen, met een kleine tegemoetkoming van $1 / 2$ reaal van achten per baar mogelijk zijn geweest, alle peper in handen te krijgen, maar Michiels heeft ,ghenen raet willen horen ende met zijn eijghen hoofft doorgheghaen", zeggende, dat hij alleen het hoofd was. Met de Chineezen heeft hij geen contract willen maken omtrent de ruwe zijde, om kort te gaan: hij was ,,zeer opstenaet”. En in zijn afkeurend oordeel staat Hendrik Janssen niet alleen: ook Peter Segers, die eveneens in Patani een rol gespeeld heeft, en nog later door ons zal worden genoemd, beklaagt zich in December 1612 over den slappen zijdehandel in Patani : dit had anders kunnen zijn, zoo verklaart hij, ,maer 't heeft voor desen bij tijden van Fernand[o] Michielssen saliger geweest, datter gelts genouch was, maer daer en werde niet gekocht".

De tijd van Michiels is dus in hoofdzaak een tijd van stagnatie geweest. Merkwaardig zijn evenwel de betrekkingen, die 't kantoor van Patani toen met andere gebieden onderhield. De gegevens hierover zijn schaarsch, maar toch valt er wel het een en ander uit op te maken. Dat Ferdinand Michiels in October 1606 in handelsverkeer staat met onzen koopman Cornelis Francx in Johor, aan wien hij dan voor ruim f 958 aan kleedjes zendt, is geen wonder: de beide kantoren lagen dicht bijeen, en wat in Patani geen aftrek kon vinden, kon misschien in Johor verkocht worden. Van meer belang is de verhouding tusschen Patani en Siam. We vernemen, dat de genoemde Cornelis Francx daarheen voor den handel op 7 April 1606 twee 
personen afvaardigde: Egbert Egbertss. en Jacques van de Perre. Ferdinand Michiels zond verder den $14^{\text {en }}$ Mei van Patani uit zekeren Willem Pietersen Tonneman naar Siam, aldus ook aandeel nemende in de regeling der zaken aldaar ${ }^{1}$ ). Het door Francx met Egbert Egbertss. en Van de Perre meegezonden cargasoen bedroeg $\mathrm{f} 7496.15 .0$, terwijl dat van Tonneman f 4378.13 .8 bedroeg ${ }^{2}$ ).

Interessant is het verder, dat het kantoor van Patani tijdens Ferdinand Michiels een uitgangspunt was voor onze vroegste betrekkingen met Borneo. Het was hier te doen om de diamanten uit Soekadana aan de Westkust. Om dezen handel te drijven, vertrok als koopman de reeds meer genoemde Hans Roeff ${ }^{3}$ ) uit Patani, waarschijnlijk in 1606. Weliswaar wist hij daar, naar we vernemen, een groote hoeveelheid diamanten op te doen, maar veel vastheid beloofde zijn bewind er niet. We weten weinig over hem, maar zooveel is zeker, dat hij er zich niet veilig voelde, en dringend verzocht, van zijn post te worden afgehaald. Daar zal ook zijn persoonlijke toestand toe meegewerkt hebben: hij moet in Soekadana in 1606 aan een zeer ernstige geestesstoring hebben geleden. Jan Willemsz. Verschoor in Bantam, die in Mei van dat jaar de noodkreet van Roeff had ontvangen, zond hierop als opvolger den koopman Bloemaert in een sloep naar Soekadana. Voor hij echter deze plaats bereikte, was Roeff, blijkbaar door grooten angst gedreven, reeds naar Patani vertrokken. Op 9 Juli 1607 kwam de ongelukkige, vergezeld van zekeren Pieter Aertss., daar aan.

Van eenigszins anderen aard is de verhouding van Ferdinand Michiels tot de oudste betrekkingen van ons volk met Japan. Deze verhouding was, zooals we zullen zien, van louter passieven aard. In $1605 \mathrm{kreeg}$ hij namelijk plotseling bezoek van zekeren Jacob Jansz. Quaeckernaeck, die kapitein was geweest op het schip de Liefde, behoorende tot de „Magellaansche vloot”, die onder Mahu en De Cordes in 1598 ons land verlaten had. Dit schip was in Japan aangekomen, en 't resultaat van dit bezoek was een octrooi, door den keizer van dit land verleend, waarbij aan de Nederlanders vrije handel werd toegestaan. Van Japan voer Quaeckernaeck, vergezeld van

1) We kunnen hieruit afleiden, dat Cornelis Specx toentertijd onzen handel aldaar niet behartigde. $\mathrm{Hij}$ was trouwens ook niet daarvoor uitgezonden (zie p. 22).

2) De Jonge III, p. 88, maakt zich schuldig aan een onjuistheid, wanneer hij zegt, dat zoowel Van de Perre als Tonneman uit Patani naar Siam gezonden waren. Eveneens Tiele Eur. 4 VIII, p. 78, noot 3.

3) Zie p. 12 . 
zekeren Melchior van Santvoort, naar Patani in een jonk, die daar 2 December 1605 arriveerde. Quaeckernaeck, die een neef was van admiraal Matelief, is later, toen hij hoorde, dat deze Malakka belegerde, over Johor naar hem toegereisd; daarna is hij in 1606 tegen de Portugeezen gesneuveld. Ook Melchior van Santvoort is niet in Patani gebleven, maar, naar we met $\operatorname{Van} \mathrm{Dijk}^{\mathbf{1}}$ ) wel mogen aannemen, weer naar Japan teruggekeerd, om zich daar metterwoon te vestigen, van waar hij dan soms weer Patani bezocht zal hebben. Zoo speelt het kantoor aldaar dan een, zij 't geringe, rol bij wat we kunnen noemen het voorspel van den uitermate veelbelovenden ${ }^{2}$ ) handel op Japan. Naar we zullen zien, komt Patani ook bij de latere meer definitieve betrekkingen met dit land te pas.

Dit is wat er viel mee te deelen over den tijd van Ferdinand Michiels, die zelf door 't gebrek aan bronnen een ietwat vage figuur voor ons blijft. Tot slot over hem nog, dat hij in Patani op 4 Augustus 1607 gestorven is aan den rooden loop, nadat hij ongeveer anderhalve maand aan deze ziekte lijdende was geweest ${ }^{3}$ ).

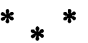

b. Het eerste bewind van Hendrik Janssen en dat van Victor Sprinckel (1607-1611).

In een gesloten brief, welken men na zijn dood vond, had Ferdinand Michiels voor het geval, dat hij mocht komen te sterven, als

1) Iets over onze vroegste betrekkingen met Japan.

2) Vg1. Stapel's voorbericht bij Van Dam II I, p. XVI.

3) Zie over het voorgaande: Van Dijk: Borneo, p. 131, 212; Van Dijk: Japan, p. 11 v., p. 19 v., p. 36 v., p. 41 noot 1; Van Dijk: Wemmer van Berchem, p. 32 noot 3; De Jonge II, p. 220 v.; III, p. 83 v. en p. 88 en bijl. XV; Tiele Eur. 4 VIII, p. 64 noot 1, p. 76, p. 78 noot 3, p. 109 v.; O. Nachod: Die Beziehungen der Niederländischen Ostindischen Kompagnie zu Japan im XVII Jahrh., Leipzig 1897, p. 103 v.; Wieder I, p. 89 v., III, p. 35, 37, 40 v.; Purchas: His pilgrimes II, p. 336; Heeres: Corpus Dipl. I, p. 69; Copiebrief van Hendrik Janssen aan Cornelis Specx in Ligor, Patani, 10 Aug. 1607 (Copieboek H. J.); Copiebrief Hendrik Janssen aan Willem Pieterss. Tonneman en Jacques van de Perre in Siam, Patani, 1 Sept. 1607 (Copieboek H. J.); Copiebrief van Hendrik Janssen aan Cornelis Specx in Sangora, Patani, 24 Sept. 1607. (Copieboek H. J.); Copiebrief van Hendrik Janssen aan de "legghers in Mancassar", Patani, 1 Oct. 1607 (Copieboek H. J.); Copiebrief van Hendrik Janssen aan Jan Willemss. Verschoor te Bantam, Patani, 29 Oct. 1607 (Copieboek H. J.) ; Copiebrief van Hendrik Janssen aan Steven Doenss. te Grissee, Patani, 29 Oct. 1607 (Copieboek H. J.); Copiebrief van Hendrik Janssen aan Cornelis Francx in Johor, Patani, 29 Oct. 1607 (Copieboek H. J.); Copiebrief van Hendrik Janssen aan Hendrik van Bergel, Patani, 29 Oct. 1607 (Copieboek H. J.); Copiebrief van Hendrik Janssen aan Frederik de Houtman op 
zijn voorloopigen opvolger aangewezen Hendrik Janssen, een Groninger van afkomst; hij heeft daar deze beschikking blijk van een juisten kijk op de belangen van de Compagnie gegeven : deze Hendrik Janssen kende niet alleen Patani grondig - hij was daar reeds sedert 1601 of 1602 - maar heeft een groote mate van bekwaamheid en van toewijding aan zijn dienst getoond: hij is de man, dien men, de geheele geschiedenis van onze factorij overziende, het eerst en met eere moet noemen ${ }^{1}$ ).

Al dadelijk kreeg hij groote moeite met de inlanders. Volgens de gewoonte werd de wisseling in het bestuur van de factorij aan 't hof bekend gemaakt, met een begeleidend geschenk. Maar hiermee waren de mandarijnen allerminst tevreden. $Z_{\mathrm{ij}}$ beweerden, dat, als een vreemd koopman daar overleed, de goederen, die hij onder zijn berusting had, door de koningin in beslag werden genomen, en dat aan deze gewoonte ook nu de hand moest worden gehouden. Janssen, vastbesloten om aan dezen eisch geen gehoor te geven, wendde nu voor, dat in dit geval de onderhoorigen van Michiels mede de goederen in handen hadden gehad, en daar ook rekenschap over zouden moeten afleggen, „hoe wel”, zoo schrijft hij naar Siam, „het inder daet zoo niet en is, maer dit hebben wij gedaen om die goederen in salve te behouden". En hoewel de mandarijnen met dezen uitleg eerst geen genoegen namen, hebben ze ten slotte toch, blijkens de ten dienste staande gegevens, hun eisch laten varen. Maar de eisch

Ambon, Patani, 29 Oct. 1607 (Copieboek H. J.); Copiebrief van Hendrik Janssen aan Cornelis Matelief, liggende voor Pahang, Patani, 8 Nov. 1607 (Copieboek H. J.); Copiebrief van Hendrik Janssen aan beww., Patani, 5 Dec. 1607 (Copieboek H. J.); Copiebrief van Hendrik Janssen aan Corn. Matelief te Bantam, Patani, 6 Dec. 1607 (Copieboek H. J.); Copie-missive van Jacques l'Hermite de Jonge aan beww., Bantam, 28 Jan. 1608; Copiebrief van Victor Sprinckel aan den keizer van Japan, Patani, 6 of 14 Febr. 1608, en memorie van goederen (Copieboek Victor Sprinckel; zie den brief bij Van Dijk: Japan, p. 15 v.); Frederik de Houtman aan Hendrik van Bergell in Banda, Amboina, 22 Febr. 1608; Copiebrief van Hendrik Janssen aan beww., Patani, 24 Sept. 1608 (Copieboek H. J.); Copiebrief van Victor Sprinckel aan Van den Broecke, Patani, 25 Sept. 1608 (Copieboek V. S.); Copiebrief van Victor Sprinckel aan Jacques l'Hermite de Jonge te Bantam, Patani, 25 Sept. 1608 (Copieboek V. S.); Victor Sprinckel aan Jacques l'Hermite de Jonge te Bantam, Patani, 27 Oct. 1608; Peter Segers aan beww. Amsterdam, Bantam, 5 Dec. 1612.

1) Een zeer lezenswaardig artikel is over hem geschreven door Prof. J. E. Heeres in den Indischen Gids, $18^{\circ}$ jaarg., dl. I, p. 101 v. Ik moet er echter op wijzen, dat hierin de bekwaamheid van $\mathrm{H}$. J. in deze eerste periode onderschat wordt, vooral waarschijnlijk wel door het feit, dat een desbetreffend citaat (p. 105), waarin over de verwatenheid van jonge Compagniesdienaren wordt geklaagd, verkeerdelijk als doelende op $\mathrm{H}$. J. wordt gegeven. 
van den extra-tol van $1 \frac{1 / 2}{2}$ realen van achten op iedere baar peper en voor andere waren navenant ${ }^{1}$ ) bleef bestaan. We begrijpen den wensch van Hendrik Janssen, dat er twee of drie van onze schepen ter reede mochten verschijnen, welke de mandarijnen, die ,alwat de beest spelen", een toontje lager zouden doen zingen. Aan den anderen kant kan men voelen voor de stemming van teleurstelling, die de inlanders moest bezielen, doordat, na een veelbelovenden inzet van onzen handel, het zoo lang wegblijven onzer schepen een onaangename stagnatie had gebracht: deze stemming was stellig niet geschikt, het respect voor de Compagnie te vergrooten. En mocht Janssen de komst dezer schepen al om redenen van prestige en ter voorziening van ons kantoor wenschen, hij had er bitter weinig lading voor gereed: nog op 1 October slaakt hij de verzuchting, dat al het voorhanden cargasoen wel in twee kleine sloepen zou kunnen worden geladen, en dat het met den handel „een meserij” is. Toch liepen reeds een maand daarvóór geruchten over de mogelijke komst van admiraal Matelief, en innig hoopte Janssen, dat deze spoedig zoowel in Patani als in Siam orde op zaken zou komen stellen. Hij zou evenwel in deze hoop teleurgesteld worden: niet Matelief zelf zou onze vestiging bezoeken, maar alleen een schip uit zijn vloot, de Mauritius, en dit zou nog tot 8 November duren ${ }^{2}$ ).

Inmiddels had Hendrik Janssen op 7 October hoog bezoek ontvangen van eenigszins ongewonen aard, namelijk een gezantschap van den koning van Siam, dat bestemd was naar patria, om zich daar in verbinding te stellen met prins Maurits en de Staten-Generaal. Met deze gezanten kwam Cornelis Specx mee, waarvan we gezien hebben, dat hij door admiraal Van Warwijck naar Siam was gezonden ter bevordering van onze handelsbetrekkingen met China ${ }^{3}$ ). Met hem kwam ook zijn tochtgenoot Lambert Jacobsz. Heyn terug,

1) Zie p. 29.

2) Zie over 't voorgaande: De Jonge III, p. 88; 't genoemde artikel van Heeres, p. 105 v.; Copiebrief van Hendrik Janssen aan Cornelis Specx in Ligor, Patani, 10 Aug. 1607 (Copieboek H. J.); idem aan Willem Pieterss. Tonneman en Jacques van de Perre in Siam, Patani, 1 Sept. 1607 (Copieboek H. J.); idem aan de „legghers in Mancassar”, Patani, 1 Oct. 1607 (Copieboek H. J.); idem aan Jan Willemss. Verschoor te Bantam, Patani, 29 Aug. 1607 (Copieboek H. J.); idem aan Cornelis Francx in Johor, Patani, 29 Oct. 1607 (Copieboek H. J.); idem aan Hendrik van Bergell, Patani, 29 Oct. 1607 (Copieboek H. J.); idem aan Frederik de Houtman op Ambon, Patani, 29 Oct. 1607 (Copieboek H. J.); idem aan adm. Cornelis Matelief te Bantam, Patani, 6 Dec. 1607 (Copieboek H. J.); Frederik de Houtman aan Hendrik van Bergell in Banda, Amboina, 22 Febr. 1608.

3) Zie p. 22 . 
terwijl verder ook Egbert Egbertss., die 7 April 1606 uit Johor naar Siam gezonden was, mee terug had zullen komen; hij was echter onderweg overleden ${ }^{1}$ ). Specx, de leider van het gezelschap, had onderweg nog Ligor bezocht, iets ten Noorden van Patani aan de kust gelegen, en daarna, zuidelijker, Sangora. Wat hij echter in deze plaatsen heeft uitgevoerd, onttrekt zich aan onze waarneming.

De aankomst van het gezantschap ging met hindernissen gepaard: het vaartuig, waarmee het aankwam, een jonk, door den koning van Siam verstrekt, verongelukte in 't gezicht van Patani en ging verloren met al wat er in was, behalve het geschenk en den brief van den koning voor zijn Prinselijke Excellentie. Terwijl nu Heyn voorloopig in Patani bleef en later weer naar Siam zou teruggaan, wachtte Specx op de komst der Hollandsche schepen, om dan daarmee als begeleider van het Siameesche gezantschap naar patria te trekken. Zoo heeft hij dit later inderdaad, om even vooruit te loopen, op de Mauritius naar Bantam begeleid, waar admiraal Matelief zich weinig gesticht toonde over deze voor de Compagnie lastige en kostbare onderneming. De bewindhebbers immers gelastten steeds, geen ambassadeurs over te voeren, ,om die groote kosten te schouwen”. Specx verklaarde echter, dat de koning van Siam het stellig als beleediging zou opvatten, als men niet evenzeer zijn gezanten wilde ontvangen als die der vorsten van Johor en Atjeh, ,dat kleyne coningen waren by hem te rekenen". Matelief bracht het lastige geval in zijn raad: het besluit was, den vorst van Siam niet voor 't hoofd te stooten, daar deze voor den machtigsten koning van Indië werd gehouden. De admiraal ontving hierop de gezanten officieel, kreeg van hen ,een kleyne sabel met gout overtogen" en zorgde voor voorloopig logies in Bantam. Later zijn de Siammers met het schip Oranje, dat ook Matelief zelf aan boord had, naar Nederland gevaren; niet alle echter: we vernemen althans, dat zekere „Ockondanpon” in Bantam werd achtergelaten, wegens de groote massa andere passagiers; hij zou daar wachten op „(Ockoncij” ${ }^{2}$ ). Het wil mij voorkomen, dat we

1) Vgl. p. 29 v. Opgemerkt moet worden, dat Sprinckel in twee brieven aan 1 Hermite (van 25 Sept. en 27 Oct. 1608) een afwijkende lezing geeft: Egbert Egbertss. zou reeds spoedig na zijn uitzending naar Siam overleden zijn. En om daarna niet alle belangen in Siam alleen op Van de Perre te laten berusten, die als „een lichtverdich voghel” te boek stond, was door Ferdinand Michiels Tonneman uit Patani gezonden. Ik geef de voorkeur aan de lezing van Hendrik Janssen, die dichter bij de gebeurtenissen stond.

2) Het eerste gedeelte, Ockon, van deze namen is een ambtstitel. (Zie Dr. F. W. Stapel: Corpus Diplomaticum Neerlando-Indicum IV, p. 393, noot 3). 
hier alleen met de twee hoofdpersonen van 't gezantschap te doen hebben; eenig gevolg moet echter uit Siam meegegaan zijn; de Oranje had namelijk, zoo hooren wij, bij zijn vertrek uit Bantam vijf Siammers aan boord. De ware reden van het achterlaten van Ockondanpon in Bantam mocht aan den koning van Siam niet worden meegedeeld; aan hem moest eventueel worden gezegd, dat de achtergelaten gezant niet recht gezond was geweest en daardoor de zeereis niet kon verdragen! Wat Specx betreft, deze heeft zijn vaderland niet teruggezien; hij overleed op reis in Juni of Juli $1608^{1}$ ). Het zou geruimen tijd duren, voor het Siameesche gezantschap weer in zijn land terugkwam ${ }^{2}$ ).

Zijn Egbert Egbertss. en Cornelis Specx een paar voorbeelden uit honderden van de vele slachtsoffers, welke de dood onder de Compagnie's dienaren opeischte, nog een derde sterfgeval onder de ons bekende personen, dat onder tragische omstandigheden plaats had, trekt onze aandacht, en wel dat van Hans Roeff, een der grondleggers van onze handelsbetrekkingen met Soekadana op Borneo ${ }^{3}$ ). In Juli 1607 in Patani aangekomen, gelijk wij zagen, was deze bestemd om met zijn tochtgenoot Pieter Aertss. een nieuwen tocht naar het genoemde eiland te ondernemen. Zijn psychische toestand schijnt echter nog steeds zeer labiel geweest te zijn, althans aan Aertss. vertrouwde hij toe, dat ,hij sorgde, dat hem nu wederom dese crancksinnicheijt an comen zoude" 3 ). Op 10 September des middags uitgegaan zijnde, gelijk hij gewoon was, kwam hij niet in de loge terug. Alle zoeken

1) Reeds vóór zijn aankomst in Patani was hij ziek geweest; „,meester” Frans uit Patani had hem daarom naar Sangora eenige „comedementen” gezonden.

2) Vgl. over het Siameesche gezantschap: Journaal Matelief (in Beg. ende Voortg., d1. II), p. 127 v., p. 134; De Jonge III, p. 62 en 88; het Overzicht, genoemd op p. 7 , noot 2, p. 411; Muller: Het land van den Witten Olifant, p. 136; Tiele, Eur. 4 VIII, p. 78; Van Dijk: Wemmer van Berchem, p. 32, noot 3; MacLeod I, p. 99; Copiebrief van Hendrik Janssen aan Cornelis Specx in Ligor, Patani, 10 Aug. 1607 (Copieb. H. J.); idem aan Willem Pieterss. Tonneman en Jacques van de Perre in Siam, Patani, 1 Sept. 1607 (Copieb. H. J.); idem aan de "legghers in Mancassar", Patani, 1 Oct. 1607 (Copieb. H. J.); idem aan Jan Willemss. Verschoor te Bantam, Patani, 29 Oct. 1607 (Copieb. H. J.); idem aan Cornelis Franex in Johor, Patani, 29 Oct. 1607 (Copieb. H. J.); idem aan Hendrik van Bergell, Patani, 29 Oct. 1607 (Copieb. H. J.); idem aan Frederik de Houtman op Ambon, Patani, 29 Oct. 1607 (Copieb. H. J.); idem aan adm. Cornelis Matelief te Bantam, Patani, 6 Dec. 1607 (Copieb. H. J.); Frederik de Houtman aan Hendrik van Bergell in Banda, Amboina, 22 Febr. 1608; Copiebrief van Victor Sprinckel aan Jacques l'Hermite de Jonge te Bantam, Patani, 25 Sept. 1608 (Copieb. V. S.); Copiebrief van Victor Sprinckel aan Lambert Jacobsz. (Copieb. V. S.).

3) Vgl. p. 30. 
en nasporen, niet alleen dien dag, maar ook de volgende dagen, leverde geen resultaat op. Den $19^{\text {en }}$ September verklaarde een Maleier, die zijn hoed had gevonden, dat hij hem aan 't strand gezien had, en dat hij daar in zee was geloopen, waarbij zijn hoed hem van 't hoofd was gevallen. De binnenlandsche justitie, door de onzen bij 't geval betrokken, maakte er weinig werk van. Tenslotte, den $22^{\text {en }}$ October ${ }^{1}$ ), vonden de Hollanders op Saberang het lijk van den ongelukkige, die blijkbaar in wanhoop een eind aan zijn leven gemaakt had $^{2}$ ).

Betrekkelijk kort na deze gebeurtenis zou eindelijk het langdurige isolement van ons kantoor te Patani, waar in ongeveer twee jaren geen Nederlandsch schip zich had vertoond, verbroken worden, en wel door de komst van 't schip Mauritius. Dit behoorde tot de vloot van admiraal Cornelis Matelief de Jonge, die in Mei 1605 met elf schepen ons vaderland had verlaten. Vier hiervan, Oranje, Mauritius, Middelburg en Erasmus, waren bestemd voor een bezoek aan Johor, Patani en China. In de meening, dat de opdracht, indertijd aan Van der Hagen verstrekt ten opzichte van de aanstelling van Frederik de Houtman met 12 assistenten in 't kantoor van Patani, zou zijn uitgevoerd ${ }^{3}$ ), gaven bewindhebbers opdracht om na te gaan, of deze personen hun plicht behoorlijk betrachtten. Op den Chineeschen handel werd groote nadruk gelegd: men moest de Chineezen er toe zien te brengen, hun waren, als zijde, suiker en porselein, in groote hoeveelheden naar Patani en Bantam te brengen. Maar ook de directe handel op China werd Matelief na aan 't hart gelegd; zoo mogelijk moest de bemiddeling van den koning van Siam hiervoor worden ingeroepen.

Matelief heeft op nauwgezette wijze getracht, zooveel in zijn vermogen was deze instructie na te komen. Alleen: de omstandigheden bleken in Indië wel eens moeilijker dan men zich in patria had voor-

1) Een copiebrief van Hendrik Janssen aan Steven Doenss. te Grissee, Patani, 29 Oct. 1607 (Copieb. H. J.) en een dito aan Cornelis Francx te Johor, Patani, 29 Oct. 1607 (Copieb. H. J.) geven: 22 Sept. Maar dit klopt slecht met de overige gegevens. Bovendien is, waar dit beide copieën zijn, verschrijving wel mogelijk geweest.

2) Vg1. over 't sterven van Roeff behalve de in noot 1 genoemde stukken nog: Van Dijk: Borneo, p. 131; Copiebrief van Hendrik Janssen aan Willem Pieterss. Tonneman en Jacques van de Perre in Siam, Patani, 1 Sept. 1607 (Copieb. H. J.); idem aan Cornelis Specx in Sangora, Patani, 24 Sept. 1607 (Copieb. H. J.); idem aan Jan Willemss. Verschoor te Bantam, Patani, 29 Oct. 1607 (Copieb. H. J.).

3) Vg1. p. 27. 
gesteld. Na een reeks van gebeurtenissen, die voor ons verhaal weinig ter zake doen, vertrok Matelief 12 Juni 1607 van Ternate met de Oranje, de Mauritius, de Erasmus en nog een jacht om betrekkingen met China aan te knoopen. Victor Sprinckel, opperkoopman op de Mauritius, was bestemd, op te treden als hoofd der factorij, die men in dit land hoopte te grondvesten. Dit liep echter op een mislukking uit; men kreeg het in September te kwaad met de Portugeezen van Macao, waarvoor men, met achterlating van het jacht, moest vluchten. 15 September verlieten de schepen China voorgoed, en, na een bezoek aan de kust van Tsi ampa ${ }^{\mathbf{1}}$ ), werd besloten, dat de Mauritius in Patani zijn last zou trachten te krijgen, de Erasmus in Johor, en de Oranje in Bantam. Er waren gegronde redenen, waarom het wenschelijk werd geacht, dat de admiraal persoonlijk Patani zou bezoeken: reeds in 1606 namelijk, nog voor zijn aankomst in Bantam, had hij getracht, het gehate en steeds lastige Malakka op de Portugeezen te veroveren, evenwel zonder succes. Daarom scheen het noodig, voor de veiligheid der onzen in Patani, dat hij met de autoriteiten aldaar een hecht verbond tegen de Portugeezen sloot. Het lot beschikte evenwel anders : door den sterken wind verviel men op $6^{\circ}$, ten Zuiden van Patani, zoodat Matelief, die haast had, Bantam te bereiken, alleen de Mauritius naar Patani afvaardigde. Hij zette nog te Pahang den koopman Abraham van den Broecke aan land, die zich naar Johor te begeven had, om over de factorij aldaar het gezag te voeren, en zette daarop zijn tocht naar Bantam voort, alwaar hij 27 November aankwam.

Inmiddels had de Mauritius den $8^{\text {en }}$ November Patani weten te bereiken. Groot was de teleurstelling van Hendrik Janssen, dat Matelief niet persoonlijk was verschenen; iemand van zoo hoog gezag immers zou uitstekend geweest zijn voor ons prestige tegenover de mandarijnen, en verder zou Janssen ook persoonlijk den admiraal gaarne hebben gesproken. Om toch eenig contact te hebben zond hij een zijner leggers, namelijk Jan Roekoe, met een brief naar Pahang, waar hij hoopte, dat de admiraal zich nog zou bevinden. Deze was echter reeds vertrokken, zoodat de brief aan den vice-admiraal ter hand moest worden gesteld.

De Mauritius bracht een groote verandering in 't bestuur van de Patanische loge. Volgens den wil van Matelief bleef Sprinckel daar als opperkoopman ${ }^{2}$ ); Janssen, aan wien nu 't oppergezag ontviel,

1) Een deel van het tegenwoordige Annam.

2) Onjuist is het verhaal van Roelof Roelofsz over den tocht van Van Neck, 
liet zich echter vinden om onder 't gezag van Sprinckel als onderkoopman te blijven, op een salaris van $\mathrm{f} 60$ per maand, om Sprinckel met zijn plaatselijke kennis van zaken ter zijde te staan.

Men kan uit het reeds boven behandelde nagaan, hoe bitter de opvarenden van de Mauritius teleurgesteld werden in hun hoop, een goede lading in Patani te vinden. Was de kleinheid van de voorhanden lading te wijten aan de mandarijnen, ook bij de koningin had men weinig succes. Voor omtrent f 1000 aan geschenken werd haar vereerd. Het poovere resultaat was, dat ze een baar peper van 380 pond naar 't schip zond. 60 à 70 last peper was ten slotte alles, wat de Mauritius aan goederen mee naar Bantam kreeg. Het is duidelijk, dat het aanzienlijke kapitaal, dat zich in Patani bevond, voorloopig beter besteed kon worden. En waar verder de Portugeesche macht in dien tijd een ernstige bedreiging vormde en de streek van Patani ,een dangeroes landt” geacht werd „,van veel capitaels te laeten”, werd er besloten, 33000 realen van achten uit het kantoor te lichten en naar Bantam te vervoeren. Mocht de handel herleven, dan zou daarvoor nog een kapitaal van 63000 realen beschikbaar blijven.

$\mathrm{Na}$ een verblijf van ongeveer een maand vertrok de Mauritius uit Patani en kwam 19 December te Bantam aan. We zagen reeds boven, dat het schip hier ook het gezantschap uit Siam bracht. Hoe critiek inderdaad de Nederlandsche vestigingen in de buurt van Malakka er voor stonden, bleek wel uit het sombere bericht, dat de fiscaal Martinus Apius met de Erasmus uit Johor bracht ${ }^{1}$ ), namelijk dat het gevaar dreigde, dat de vorst aldaar vrede met de Portugeezen zou sluiten ${ }^{2}$.

als hij zegt, dat Sprinckel in Patani voor opperkoopman gelegen heeft ,in de jaren 1616" (p. 16).

1) Onjuist is, wat De Jonge meldt (III, p. 62), dat 't schip Erasmus uit Patani kwam.

2) Vgl. over 't bezoek van de Mauritius: Journaal Matelief, p. 119 v., 127 v., 131; De Jonge III, p. 57 v., 62, 84, 88; Tiele Eur., 4 VIII, p. 73 v., 77; Van Dijk: Japan, p. 12 v.; Netscher: Johor en Siak, p. 14 v.; Groeneveldt, p. 23 v.; Heeres: Hendrik Janssen, p. 105; MacLeod I, p. 58; Muller: Onze vaderen in China, Gids 1917, I, p. 323; Wieder III, p. 39; Van Dam II I, p. 325; Copie-res. Heeren XVII in hun vergad. v. 9 Mt. 1605; Copiebrief van Hendrik Janssen aan Cornelis Specx te Sangora, Patani, 8 Sept. 1607 (Copieboek H. J.); idem aan adm. Cornelis Matelief, liggende voor Pahang, Patani, 8 Nov. 1607 (Copieb. H. J.); idem aan adm. Cornelis Matelief te Bantam, Patani, 6 Dec. 1607 (Copieb. H. J.); Copie-missive van Jacques l'Hermite de Jonge aan beww., Bantam, 28 Jan. 1608; Lambert Jacobsz. Heyn aan beww. te Amst., Patani, 3 Febr. 1608; Copiebrief van Victor Sprinckel aan den keizer van Japan, bedoeld in noot 3 van p. 31 ; „Discours op de handelinghe, die men in Oost India 
Dat dan ook Patani gevaar zou loopen, ligt voor de hand. Niemand, die hier meer van doordrongen is dan admiraal Matelief. Hij vindt het risico, dat de Compagnie in deze plaats loopt, veel te groot. En niet alleen de Portugeezen zijn er gevaarlijk, de Nederlanders worden er ook ,van de Mandorijns dapper gequelt”. De financieele resultaten zijn gering, ,ende daer houden wy sulcken costelycken comptoir met soo veel schenkage te geven, soo dat ons de waren hondert ten hondert te duer comen te staen". De peper, die men er koopt, is maar voor een klein deel uit 't land zelf afkomstig, en wordt meest uit Jambi aangevoerd; de Chineesche waren zullen nooit het rechte voordeel geven: maakt men voorkoop met de Chineezen, dan zullen ze ons bij de leverantie bedriegen; wachten we af, wat er uit China wordt aangevoerd, dan brengen ze alleen wat de mandarijnen en 't hof begeeren, daar ze dan geen zekerheid hebben, de rest te verkoopen ${ }^{1}$ ). Men kan, als we eerst Jacatra voldoende zeker in bezit hebben, de Chineezen daarheen lokken; peper valt er genoeg te krijgen in Jacatra, Bantam en Johor. Opheffing van 't kostbare en onnutte kantoor is dus raadzaam: door particulieren kan de plaats dan met kleedjes worden bevaren; wat dezen terugbrengen, kan in Jacatra worden verkocht. Matelief vindt dit punt van zoo groot belang, dat hij ook na zijn terugkomst in patria, ja zelfs nog in 1610, erop teruggekomen is ${ }^{2}$ ).

Indië verlatende treft hij 2 Februari 1608 in de straat van Bantam (dus blijkbaar straat Soenda) het schip Gouda ${ }^{3}$ ) aan, dat onderweg is naar Bantam. Hij zendt dan een brief aan l'Hermite in laatstgenoemde plaats om dezen den raad te geven, door middel van dit schip de kapitalen alvast voor 't overgroote deel uit Johor en Patani te doen lichten, daar men nooit kan weten, of de inwoners niet tot vrede met de Portugeezen zullen komen. l'Hermite volgt dit advies op en laat de Gouda na aankomst in Bantam gereed maken voor

van wege de Vereenichde Comp ${ }^{i e}$ soude mogen drijven" door Corn. Matelief de Jonge, 12 Nov. 1608 (Rotterd. Historiebladen III, deel I, p. 265 v.; Copie van het verzeilen van de vloot van Matelief, bedoeld in noot 2 van p. 28.

1) Beter nog dan Patani zou Matelief een plaats onder 't gezag van den koning van Bordelon (ten $\mathrm{N}$. van Patani) voor den Chineeschen handel vinden.

2) In een Discours van den stand van Oost-Indië van 12 Nov. 1608 noemt Matelief Patani onder de (overigens vele) kantoren, die de Compagnie dient te bewaren. $Z_{\text {ijn }}$ aanduidingen in tegengestelden zin zijn echter zoo duidelijk, dat hij hier zal bedoelen: voorloopig bewaren, of dat Patani eenvoudig door sleur bij zijn opsomming geraakt is.

3) Dit was een der uit patria nagezonden schepen, die behoorden tot de vloot van Van Caerden. 
dezen tocht. Met een lading kleedjes als koopwaar vertrekt het schip 11 Maart. Van de \pm 63000 realen van achten, die men in Patani vermoedde, zou men er hoogstens een 3000 mogen laten.

Onder leiding van den koopman Dirk Evertsen Smidt kwam de Gouda 5 Augustus voor Patani,' na aan haar instructie aangaande Johor voldaan te hebben. Bij het aan land brengen van de kleedjes werd getracht, zoo weinig mogelijk aan invoerrecht hiervoor te betalen: een aantal balotten werd ,versweghen” en ,bij nachte aen lant ghebracht"; voor de andere gelukte het - een novum, waar Sprinckel zeer trotsch op is - de $5 \%$ tol tot $4 \%$ terug te brengen. Maar hiermee was men er nog niet: tal van inlanders moesten met schenkages bedacht worden, van de koningin af - die ter waarde van meer dan f 142 ontving - tot aan haar danseressen, die de ontvangst der Hollanders ten hove opgeluisterd hadden.

Het hoofddoel, met de zending van de Gouda beoogd, werd niet bereikt: Sprinckel was allerminst van zins, het kantoor van bijna alle kapitaal te ontblooten. Het Portugeezengevaar was bij hem blijkbaar een veel minder belangrijke factor dan bij Matelief. Verder beschikte hij toentertijd lang niet over 't groote bedrag, dat men in Bantam verondersteld had, maar ten hoogste over 19000 realen. Waar hij nu goederen op voorkoop van de Chineezen had gekocht, en voor de toekomst van deze handelsbetrekkingen geen insolventie onzerzijds bij levering der beloofde goederen wilde riskeeren, weigerde hij, aan de instructie gevolg te geven, welke de koopman Smidt hem voorlegde. Ja, hij verklaarde zelfs, dat het een groote teleurstelling voor hem was, uit de Gouda geen extra-kapitaal te ontvangen. 't Spreekt echter vanzelf, dat Smidt hiermee zonder meer geen genoegen kon nemen; weliswaar besloot hij met zijn scheepsraad, na de argumenten van Sprinckel gehoord te hebben, 't kapitaal in Patani te laten, maar er werd een protest tegen onze leggers in dit kantoor opgesteld, waarin de toedracht van zaken nauwkeurig werd beschreven; en hierop verlangde hij de onderteekening van Sprinckel en de zijnen, die aan dit verzoek voldeden.

Daar de Gouda in Johor reeds een groote lading peper en sandelhout had ingekregen, kon Sprinckel er tot zijn spijt niet alles, wat hij voorradig had, mee naar Bantam zenden. Toch bedroeg de lading uit Patani nog een waarde van meer dan f 34000 , gedeeltelijk peper, maar ook fluweel, satijnen, damast, zijde, benzoë en andere goederen. Een deel van de Patanische peper moest dus op andere scheepsgelegenheid wachten. 26 September vertrok de Gouda, met de bedoeling, 
onderweg naar Bantam nog Pahang aan te doen, gelegen ongeveer halverwege Johor, om aldaar zoo voorzichtig mogelijk informatiën in te winnen omtrent den stand van zaken in laatstgenoemde plaats. 20 November 1608 is het schip weer in Bantam teruggekomen.

Dat Sprinckel en zijn raad eigenmachtig hadden gehandeld tegen de instructie, aan de Gouda meegegeven, zou voor onze factorijhouders nog onaangename gevolgen kunnen hebben, niet alleen in Bantam, maar ook in patria. Ik zinspeelde er reeds op, hoezeer Matelief er voor gepleit heeft, het kantoor Patani niet alleen van kapitaal te ontblooten, maar het zelfs op te heffen. Bewindhebbers zouden ten slotte te beslissen hebben. Welnu, de XVII stelden den bekwamen admiraal in 't ongelijk, en besloten op 25 Maart 1609, dat 't kantoor van Patani niet ,teffens" zou worden opgebroken, maar dat daar eenige ondercommiezen met weinig cargasoen zouden gelaten worden onder een opperconimies, die elders resideerde. En na kennisneming van een door Sprinckel aan l'Hermite geschreven brief, waarin de eerste zich op de meest krasse wijze tegen de afbraakplannen van Matelief verzet, bevestigen ze in September 1609, onder verwijzing naar diens brief, uitdrukkelijk, dat 't kantoor te Patani niet zal worden opgeheven en gelasten zelfs, Sprinckel uitzicht op verbetering van tractement te geven, zoo hij zich wil verbinden, de Compagnie nog drie jaren in Indië te dienen ${ }^{1}$ ).

1) Vgl. over Matelief's oordeel en het bezoek van de Gouda: Journaal Matelief, p. 127,131 v., 134; Valentyn III IIc, p. 90; De Jonge III, p. 239 (in bij1. XIV) en bij1. XV; Tiele Eur. 4 VIII, p. 78; MacLeod I, p. 69; Copie-missive van Jacques l'Hermite de Jonge aan beww., Bantam, 28 Jan. 1608; Matelief aan Jacques l'Hermite te Bantam, in de straat van Bantam, 2 Febr. 1608; Copie-instructie voor 't schip Gouda, Bantam, 8 Febr. 1608; Copiebrief van Victor Sprinckel aan Abraham (van den Broecke?), Patani, 1 April 1608 (Copieboek V. S.); idem (aan denzelfden?), Patani, 1 Mei 1608 (Copieboek V. S.); Memorie van Victor Sprinckel voor de Chineezen, 28 Juni 1608; Victor Sprinckel aan Lambert Jacobsz. Heyn, Patani, 30 Juni 1608; Victor Sprinckel aan Lambert (Jacobsz. Heyn?), Patani, 20 Juli 1608; Copiebrief van Jacques l'Hermite aan beww., Bantam, 24 Juli 1608; Victor Sprinckel : Memorie van de kleedjes, Patani, 10 Aug.-28 Oct. 1608; Victor Sprinckel, factuur der goederen, gescheept in 't schip Gouda, Patani, 10 Sept. 1608; Protest tegen Victor Sprinckel, 24 Sept. 1608; Victor Sprinckel: factuur der goederen, afgezonden met de Gouda, Patani, 25 Sept. 1608; Copiebrief van Victor Sprinckel aan Van den Broecke, Patani, 25 Sept. 1608 (Copieboek V. S.); Copiebrief van Victor Sprinckel aan Jacques l'Hermite de Jonge te Bantam, Patani, 25 Sept. 1608 (Copieboek V. S.); Victor Sprinckel aan bewindhh. te Amst., Patani, 25 Sept. 1608; Copiebrief van Victor Sprinckel aan Cornelis (?), Patani, Sept. 1608 (Copieboek V. S.);Discours van den stand van Oost-Indië van Cornelis Matelief de Jonge, Rotterdam, 12 Nov. 1608 (Rotterdamsche Historiebladen III, deel I, p. 237 v.) ; het „Discours” in Rott. historie- 
Werkelijk schijnt Matelief omtrent Patani te pessimistisch geweest te zijn. Want al mag 't waar zijn, dat iedere factorijhouder graag nadruk legt op 't belang van zijn kantoor, daarmee hopende, eigen positie te versterken, de ons ten dienste staande berichten geven den indruk van oprechtheid. Zeer reëel is bijv. het door Sprinckel behaalde succes, dat voor 1609 aan uitgaande rechten voor zijde en zijdewaren $31 / 2 \%$ zal worden geheven in plaats van $5 \%$, zooals tot dien tijd gebruikelijk was. Hij hoopte dezelfde tegemoetkoming ook voor den peperuitvoer te bewerken. Was Sprinckel reeds vóór de komst van de Gouda tevreden over 't beloop van den handel, de berichten, door hem en Hendrik Janssen met de Gouda meegezonden, zijn zeer optimistisch; een aanzienlijk deel der door dit schip aangebrachte kleedjes was toen al verkocht. In een lateren brief schrijft Sprinckel aan l'Hermite, dat Patani hem voor kleedjes, mits goed van kwaliteit en niet te duur ingekocht, de beste verkoopplaats van geheel Indië lijkt. Ook van Engelschen kant wordt ons bevestigd, dat er omstreeks dezen tijd in Patani zooveel vraag naar doeken was, dat men er niet genoeg kon aanbrengen ${ }^{1}$ ). De peperinkoop had in 't laatst van 1608 een voorspoedig verloop.

Vanwaar die gunstige wending voor onze factorijhouders? Ten eerste, zegt Sprinckel, zien de inlanders in, hoezeer de Nederlandsche handel in hun eigen belang is, ze merken, ,dat haer stadt ofte platse door ons in de coopmanschap meer ende meer floreert". En dan: het voortreffelijke gedrag en de tact der onzen! Door ,"'t wel beleven, ende hem bemint te maken" komen ze steeds meer in de gunst bij de ,mandorins" niet alleen, maar ook bij ,,alle 't gemente in 't generale”. „Superbijtheyt, oochmoedicheijt ende groote overdiemackinghe" 2), vervolgt Sprinckel, kunnen nooit tot een goede verstandhouding leiden, ,Ick bevinde, dat dese moren met alle liefsamicheyt ende vrintschap willen geconverseert wesen". Gelukkig dan ook, dat de Hollanders hun ,.gheen ontstichtinghe van quaet leven en gheven" ${ }^{3}$ ).

bladen, genoemd in noot 2 van p. 38; Jacques l'Hermite de Jonge aan Pieter Willemss. Verhoef voor Malakka, Bantam, 29 Dec. 1608; Rekening van de schenkage voor 't schip Gouda gedaan, Patani, 1608; Copie-res. XVII, 25 Mt. 1609 ; Res. XVII, 5 Sept. 1609; Copie-Betoog van Matelief, dat het niet geraden is, Johor tot zetel van den G.-G. te kiezen, 31 Aug. 1610, Rott. Historiebladen III, deel I, p. 328 v.; Copiebrief van Victor Sprinckel aan Lambert Jacopssen (Copieboek V. S.).

1) Moreland: Peter Floris, p. 41 v.

2) Eig. : hoovaardij-making.

3) Zie over 't voorgaande: Heeres: Hendrik Janssen, p. 109 v.; Victor Sprinckel aan Lambert Jacobsz. Heyn, Patani, 30 Juni 1608; Hendrik Janssen 
Helaas, hoe spoedig zou voor Sprinckel een bittere ontgoocheling komen, hoe zouden zijn landgenooten deze goede reputatie als met één slag vernietigen! Ruim een maand na het vertrek van de Gouda werd Patani bezocht door de schepen Gelderland en Kleine Zon, het eerste, evenals de Gouda, een nagezonden schip van de vloot van Van Caerden, de Kleine Zon met Matelief uit patria gekomen. Gezamenlijk waren deze schepen uit Ternate gevaren; na een bezwaarlijke, nog door geen ander schip aldus volbrachte reis van drie maanden benoorden Borneo om en langs de kust van Tsi-ampa bereikten ze op 4 November 1608 Patani, welke plaats oorspronkelijk niet op 't program van den tocht gestaan had. Daar ze er een grooten voorraad peper aantroffen, werd besloten, dat de Gelderland deze zou inladen. Het scheepsvolk echter, blijkbaar niet van 't beste gehalte. waarschijnlijk aan slechte discipline gewend en misschien ook behoefte gevoelend aan expansie na den met moeite doorstanen tocht, bereidde én aan het bestuur der beide schepen én aan onze leggers de grootste moeilijkheden. Het begon reeds op 5 November, toen Victor Sprinckel op straat zekeren Hillebrant Pieters, bijgenaamd Verlangher, vechtende aantrof, die ook reeds op 't schip een ongunstigen naam had. $\mathrm{Na}$ een vermaning liep Sprinckel door, maar kort daarna kwam Pieters gekwetst de loge binnen, alwaar hij in de boeien werd gezet. Spoedig verschenen echter vier van zijn trawanten, die zijn bevrijding eischten; ze braken de poort van de loge open, klommen over de omheining, ,goijden met potten, steenen, smeeten met alles wat sij conde becomen om den Verlangher wt de boeijen te crijghen”, en brachten 't zoo ver ,door haer geweldichgen overlust ende moetwille", dat de arrestant werd losgelaten. 't Behaalde succes deed naar meer heldendaden verlangen: den volgenden dag kwamen ongeveer honderd man, ten deele met sabels en krissen gewapend, die van boord waren meegenomen of aan land gekocht, de stad Patani verontrusten, zoodat de inwoners aan de loge kwamen klagen. De Hollanders aldaar, die ook geen raad wisten, togen naar 't hof, waarbij ze onderweg een der vier muiters van den vorigen dag aantroffen,

aan Jacques l'Hermite te Bantam, Patani, 24 Sept. 1608; Copiebrief van Victor Sprinckel aan Van den Broecke, Patani, 25 Sept. 1608 (Copieb. V. S.); idem aan Jacques l'Hermite de Jonge te Bantam, Patani, 25 Sept. 1608 (Copieboek V. S.); Victor Sprinckel aan beww. te Amst., Patani, 25 Sept. 1608; Victor Sprinckel aan Jacques l'Hermite de Jonge te Bantam, Patani, 27 Oct. 1608; Copiebrief van Hendrik Janssen aan Jacques l'Hermite te Bantam, Patani, 30 Oct. 1608 (Copieboek H. J.) ; Hendrik Janssen aan l'Hermite te Bantam, Patani, 10 Nov. 1608. 
Tuenis Copss. genaamd, die meende te ontvluchten, maar hierbij zoo zwaar gewond werd, dat hij acht dagen later overleed. De koningin gaf een paar honderd man ter assistentie aan de bedreigde logehouders, waarop Hillebrant Pieters wederom in de boeien gezet werd, nu met zijn vier trawanten. De raad van de loge en de beide schepen, onder voorzitterschap van Sprinckel, vond, dat de schuldigen behoorden gestraft te worden ,ten exempel van andere, datter den doot nae volcht", maar tot uitvoering van dit vonnis ging men niet over, ten eerste uit vrees voor de vele aan land zijnde medeplichtigen, en vervolgens ook omdat de inwoners niet tot de doodstraf wilden medewerken. Daarom besloot men, de schuldigen gevangen te houden tot de komst der volgende schepen, en hun maandgelden verbeurd te verklaren. De Compagnie, zoo schrijft Sprinckel aan l'Hermite, had hierbij groot risico geloopen, ,soo van 't verliesen der schepen, oock meede alle haere goederen ende cappitael hier te lande, ende wij alhier te lande met alle de overicheijt van de schepen in duijssent danghieren van 't leven".

Den $11^{\text {en }}$ November voer de Kleine Zon naar Bantam ${ }^{1}$ ), de sententie omtrent de muiterij daarheen meebrengende; verder verzocht Victor Sprinckel, in April 1609 een schip naar Patani te zenden, waardoor dan de waren betaald zouden kunnen worden, die men met de Chineesche jonken dacht te ontvangen. Men begon nu op 12 November de beschikbare peper in 't schip Gelderland te laden, maar ook hierbij kwam de losbandige aard van 't scheepsvolk opnieuw tot uiting. Ja, de opperkoopman van het schip, Hendrik Janssen Craen geheeten, aan land zijnde, is vrijwel wanhopig, als hij schrijft: „Voorders soo heb ick hier aen landt seer grootte moeijte met ons volck, niet alleen bij daeghe, maer moet 's nachts ende 's morghens voor daech die selve rondom in de hoer ende arackhuijssen gaen haellen, soo dat ick se dan in de boeijen set, daechs wt sluijtende om te arbeijden, gearbeyt hebbende, laet se weeder in de boeijen setten, want ick weet er anders geen remedie toe". Ook het feit, dat de Chineezen en Maleiers, die met prauwen de peper naar ' $t$ schip brachten, allerlei moedwil van 't scheepsvolk moesten ondergaan, b.v. met zakken en andere dingen gegooid werden, deed aan de reputatie der onzen zeer veel afbreuk. Het laden van de Gelderland werd natuurlijk aldus zeer vertraagd. Op 19 November was ruim $2 / 3$ van de ruimte van 't schip volgeladen met ruim 1300 baren peper, waarvoor met inbegrip van onkosten

1) Ten onrechte zegt MacLeod, dat de Gelderland ook mee naar Bantam ging (I, p. 71). 
f 62767.8 .11 betaald was. Den $22^{\text {en }}$ November bracht Craen zijn afscheidsbezoek bij de koningin, die hem een kris met gouden heft schonk, en twee dagen later koos de Gelderland zee. Maar wind en weer werkten niet mee; tot twee maal toe moest men weer naar Patani terugkeeren, en eerst 3 Maart 1609, zeer veel later dus dan men gehoopt had, zette het schip definitief koers naar Bantam ${ }^{1}$ ).

Behalve in Patani werd in Sprinckel's tijd ook reden tot ergernis door ons volk gegeven in Siam. In de loge van Ajudhja ${ }^{2}$ ) liet 't beleid van Van de Perre cn Tonneman ${ }^{3}$ ) alles te wenschen over. In den handel werd er weinig uitgevoerd, ze gaven veel uit, en verkochten zijde, die dienstig geweest zou zijn voor patria, om maar aan geld te komen. Vooral ergert Sprinckel zich over 't feit, dat Van de Perre ,alleene om eeneghe clapperie ofte spreecwoorden” den sabandar, een der voornaamste hofdienaren, een proces heeft aangedaan, een proces, dat geld bij massa's verslindt, en reeds hierom hopeloos is, dat alle stukken, die men tot den koning richt, door de handen van dezen tegenstander moeten gaan! Sprinckel is dan ook al spoedig van oordeel, dat Van de Perre, ,een wilden hane”, naar hij verstaat, en Tonneman moeten worden teruggeroepen. Trouwens ook Hendrik Janssen en Matelief waren reeds van dezelfde meening geweest. In Februari 1608 werd dan ook door Sprinckel een jonk naar Siam gezonden om orde op zaken te stellen. Hiermee ging als nieuw hoofd van 't kantoor te Adjudhja dezelfde Lambert Jacobsz. Heyn, dien we reeds op last van admiraal Van Warwijck daarheen zagen gaan. Als assistent was Jacob Adriaensen hem toegevoegd; met hen ging ook de bootsman Pieter Hendrikss., die evenwel niet bestemd was, er te blijven; het schijnt, dat hij bedoeld was als overbrenger van goederen tusschen de beide kantoren Ajudhja en Patani.

1) $\mathrm{Z}$ ie over 't voorgaande: Heeres: Hendrik Janssen, p. 111; MacLeod I, p. 65 v., 71; Journaal gehouden op het schip Gelderland door Hendrik Jansz. Craen, 3 April 1607-18 Juni 1610; Attestatie en sententie van Jan Arentsen enz., Patani, 8 Nov. 1608; Hendrik Janssen aan l'Hermite te Bantam, Patani, 10 Nov. 1608; Victor Sprinckel aan l'Hermite te Bantam, Patani, 10 Nov. 1608; Hendrik Janssen Craen aan schipper Jan Janss. Mol, Patani, 14 Nov. 1608; Copiebrief uit ' $t$ schip de Kleine Zon an Paulus van Caerden in de Molukken, 23 Nov. 1608; Victor Sprinckel aan Jacques l'Hermite te Bantam, Patani, 24 Nov. 1608; Hendrik Janssen Craen aan Jacques l'Hermite te Bantam, Patani, 10 Dec. 1608 (foutief voor 10 Nov.?); Jacques l'Hermite de Jonge aan Pieter Willemss. Verhoef voor Malakka, Bantam, 29 Dec. 1608

2) De toenmalige hoofdstad van Siam.

3) Zie p. 29 v. en 33 v.

4) Zie p. 22. 
Voor een waarde van ongeveer f 8000 aan goederen, die men in Patani niet goed kwijt kon, werd als cargasoen met de jonk meegezonden. Aan Van de Perre en Tonneman werd door Sprinckel een brief gezonden, waarin hun handelsmethoden gelaakt werden: de goederen, door hen ingekocht en dienstig voor Patani, mochten niet meer door hen verkocht worden, maar moesten per eerste gelegenheid worden overgezonden. Verder moest 't absoluut uit zijn met het procedeeren tegen den sabandar. Hoe kunt ge toch, zoo uit zich Sprinckel, zoo onbezonnen zijn, tegen iemand van zoodanigen invloed op te treden! ,'t En is gheen kinder spil, met groote heeren te spootten; sij spelen met hu, gelyck de katte mette muijs doet". En bovendien: ,'t en is gheenen tyt, mooren tot vianden $t^{\prime}$ hebben, want wij hebbender ghenouch, Godt beter ' $t$ '. Aan Heyn moesten daarom alle processtukken uitgeleverd worden; deze kreeg last, tot allen prijs een eind aan het geschil te maken, dat ook in financieel opzicht zeer schadelijk voor ons was. Zoo spoedig mogelijk moesten Van de Perre en Tonneman zich naar Patani begeven; in April of Mei, zoo hoopte Sprinckel, zouden ze daar kunnen zijn.

De taak van Heyn bleek niet tot de aangenaamste te hooren. Wel gelukte het, aan het kostbare proces tegen den sabandar een eind te maken, maar op 't punt van gezagsuitoefening was 't met Heyn treurig gesteld. Van de Perre en Tonneman weigerden om, zooals hun gelast was, hun cargasoen aan het nieuwe opperhoofd uit te leveren; Heyn beklaagt zich er verder over, dat Van de Perre hem belastert, en er blijkbaar niet overheen kan komen, dat zijn invloed bij den koning verdwenen is, doordat nu telkens Heyn aan 't hof ontboden wordt en niet hijzelf. De wrok van Van de Perre was blijkbaar de reden ervan, dat hij over alles slechts met Tonneman te rade ging, en Heyn liefst buiten alles hield. Ook aan de uitdrukkelijke lastgeving, zoo spoedig mogelijk naar Patani te vertrekken, gaven de twee geen gehoor; hoewel ze daar volgens Heyn al in Juni 1608 hadden kunnen zijn, liep het aan tot begin 1609, eer ze eindelijk kwamen, ook al weer, zoo hooren we, door eigen schuld. Wat hen namelijk zoo lang in Siam hield, was stellig een zeer ongewoon ondernemen, niet geschikt, het vertrouwen der superieuren in hen te vergrooten. Ze trachtten namelijk met alle macht, van den koning een gouden ,,bougette" ${ }^{1}$ ) te verwerven, die aan den bezitter de macht zou geven, steden en dorpen te brandschatten en aldus

1) Waarsch. wel gelijk aan Fr. baguette, dat hier dan wel tooverstokje zal beteekenen. 
groote hoeveelheden goud en zilver machtig te worden. Daar de koning echter 't mirakuleuze voorwerp onder geen beding wilde afstaan, waren tijd en kosten, aan deze poging besteed, volkomen vergeefsch.

Of Lambert Jacobsz. Heyn, bij alle ergernis, die hij over Van de Perre en Tonneman uit, zelf geheel van schuld vrij te pleiten is? Tactisch schijnt zijn optreden in elk geval niet geweest te zijn. Sprinckel geeft onbewimpeld zijn ongenoegen te kennen, als hij verneemt, dat Heyn met de beide anderen verscheiden tafel houdt. Niet alleen, zegt hij, worden daardoor de mondkosten te ,excessijf”, terwijl 't toch ,,al wt een beurse compt”, maar ,waer dissentie oofte twedracht is, en gont den Heere syne gratye niet”. ,,Ghij en meucht”, zoo vervolgt hij, ,,met sulck een qua hooft niet toegaen, men moet wat toelereren d'eens d'ander cranckheyt, ende water in syn wijn doen". Men moet de menschen behandelen met zachtheid, niet met „rudicheyt”. Pieter Hendrikss. had zich op hevigen toon over Heyn beklaagd, en de assistent Adriaensen had om dezelfde reden zelfs reeds zijn terugroeping verzocht. Ook tegenover de inlanders is zijn gedrag blijkbaar niet soepel genoeg: ,wij moeten”, zegt Sprinckel, „,noch met haerlieder wat simuleren, tot dat Godt versiet”. Alleen in de jeugd van Heyn ziet hij een verzachtende omstandigheid.

Een beteren indruk krijgen we van diens handelstalenten. In dit opzicht betuigde Sprinckel bij herhaling zijn tevredenheid over hem.

Siam schijnt toen onder andere een gunstig afzetgebied geweest te zijn voor zwarte lakens, die men in Patani over had. Ook stelde Heyn zich voor, dat men door beïnvloeding van den koning van Siam misschien afschaffing van de tollen in Patani zou kunnen bewerken. Daarom diende vooral gelet te worden op de persoonlijke wenschen van den koning, die hem 9 Mei tot tweenaal toe bij zich geroepen had met 't verzoek, aan 't kantoor van Patani te vragen om ,eeniegen prenten ende scheepkens, die geprent ofte met de pen getrocken zijn", en eenige andere „fraijecheeden”. Sprinckel kon aan dit verzoek niet voldoen, daar de Chineezen in Patani alle bedoelde prenten gekocht hadden. Later doet Heyn nog tot twee maal toe aan Sprinckel 't verzoek, hem eenige Hollandsche fluweelen voor den koning te zenden. Het wil me voorkomen, dat Heyn, wanneer hij door dergelijke middelen tolvrijheid in Patani tracht te bereiken, de zelfstandigheid der Patanische koningin ten opzichte van haar leenheer onderschat ${ }^{1}$ ).

1) Zie over de Siamsche kwesties: De Jonge III, p. 88; Tiele Eur. 4 VIII, p. 78 noot 3; Copiebrief van Hendrik Janssen aan Willem Pieterss. Tonneman en 
Toen Heyn in Februari 1608 naar Siam vertrok, werd Melchior van Santvoort, dien we reeds in verband met de Japansche zaken hebben leeren kennen ${ }^{2}$ ), met hem meegezonden. Hij moest trachten, de betrekkingen tot Japan, die sedert het bezoek van Quaeckernaeck in dit land op een dood spoor geraakt waren, opnieuw aan te knoopen. Daar dit land niet alleen een geschikt afzetgebied voor de Compagnie zou kunnen worden, doch men er ook eetwaren, koper en zilver vandaan zou kunnen krijgen, was het van groot belang, zich bij voortduring van de gunst van den keizer te verzekeren. Tot dat doel kreeg hij een brief van Victor Sprinckel voor dezen mee, waarin de vorst door de factorijhouders van Patani uit naam van prins Maurits gegroet werd. Sprinckel spreekt er zijn leedwezen over uit, dat het plan van Matelief, hem in China als factor achter te laten, niet had kunnen worden uitgevoerd; ware dit gelukt, hij zou stellig in staat geweest zijn, een flinke lading zijde en zijdewaren naar Japan te zenden. De keizer werd echter dringend verzocht, zijn gunstige gezindheid

Jacques van de Perre in Siam, Patani, 1 Sept. 1607 (Copieb. H. J.); Copiebrief van Victor Sprinckel naar Johor aan Abraham van den Broecke, Patani, 28 Dec. 1607 (Copieb. V. S.); Cornelis Franex aan Bewindhh., 27 Jan. 1608; Factuur der goederen, gezonden voor Victor Sprinckel aan Lambert Jacobsz. Heyn, Patani, 1 Febr. 1608; Copiebrief van Hendrik Janssen aan Jacques van de Perre en Willem Pietersen Tonneman, Patani, 1 Febr. 1608 (Copieb. V. S.); Instructie voor Lambert Jacobsz. Heyn en assistenten, Patani, 1 Febr. 1608; Lambert Jacohsz. Heyn aan beww. te Amst., Patani, 3 Febr. 1608; Copiebrief van Victor Sprinckel aan Abraham (van den Broecke?), Patani, 1 April 1608 (Copieb. V. S.); Copiebrief van Lambert Jacobsz. Heyn aan Victor Sprinckel, Ajudhja, 7 Mei 1608; Victor Sprinckel aan Lambert Jacobsz. Heyn, Patani, 30 Juni 1608; Copiebrief van Victor Sprinckel aan Lambert (Jacobsz. Heyn?), Patani, 14 Juli 1608 (Copieb. V. S.); Victor Sprinckel aan Lambert (Jacobsz. Heyn?), Patani, 20 Juli 1608; Factuur der goederen, door Victor Sprinckel naar Siam gezonden, Patani, 25 Aug. 1608; Copiebrief van Lambert Jacobsz. Heyn aan Victor Sprinckel, Ajudhja, 26 Aug. 1608; Factuur der goederen, door Victor Sprinckel gezonden naar patria met 't schip Gouda, Patani, 25 Sept. 1608; Copiebrief van Victor Sprinckel aan Van den Broecke, Patani, 25 Sept. 1608 (Copieboek V. S.); idem aan Jacques l'Hermite de Jonge, te Bantam, Patani, 25 Sept. 1608 (Copieb. V. S.); Victor Sprinckel aan beww. te Amst., Patani, 25 Sept. 1608; Copiebrief van Lambert Jacobsz. Heyn aan Victor Sprinckel, Ajudhja, 26 April 1608; Copiebrief van Victor Sprinckel aan „Cornelis”, Patani, Sept. 1608 (Copieboek V. S.); Victor Sprinckel aan Jacques l'Hermite de Jonge te Bantam, Patani, 27 Oct. 1608; Victor Sprinckel aan l'Hermite te Bantam, Patani, 10 Nov. 1608; Copiebrief van Lambert Jacobsz. Heyn aan Victor Sprinckel, Siam, 13 Dec. 1608; idem aan Victor Sprinckel, Siam, 7 Mei 1609; Copiebrief van Hendrik Janssen aan „Lambart Jacobss." (Heyn?) in Siam, Patani, 23 Mei en 8 Juni 1609 (Copieb. H. J.); Copiebrief van Victor Sprinckel aan Lambert Jacobssen.

2) Zie p. 31 . 
jegens de Hollanders te bewaren, en geen geloof te slaan aan de lasterpraatjes, die de Portugeezen zouden mogen verspreiden om onzen roem te verkleinen. Aan den brief werd voor den vorst een „schenkage" toegevoegd, die bestond uit 6 groote en 9 kleine kommen, 12 schotels, 3 ,geijsde bekers met pipen”, een ,acker cop”, 3 Fransche kelken, 5 klare kristallijnen bekers, 4 gestreepte bekers, 7 Fransche wijnglazen, 13 Danziger flesschen, 10 blauwe ronde flesschen, 7 kleine kommetjes en 10 el zwart laken. Brief zoowel als geschenken moesten aan den keizer ter hand gesteld worden door een Engelschman William Adams, die bijzonder bij den keizer in de gunst stond ${ }^{1}$ ).

Het jaar 1609 zou aan de herhaalde pogingen van Nederland ten opzichte van Japan eindelijk de bekroning geven. Dit hing samen met een tocht van het schip de Roode Leeuw met Pijlen en het jacht de Griffioen, beide behoorende tot de vloot van admiraal Verhoeff, die op 22 Dec. 1607 ons land verliet ${ }^{2}$ ). Deze beide schepen, voor Johor liggende, ontvingen op 4 Mei 1609 door middel van een sloep ${ }^{3}$ ) een lastgeving van admiraal Verhoeff op grond van adviezen en instructiën van bewindhebbers, die aan dezen admiraal na zijn vertrek uit ons land waren nagezonden. Daar er sprake ging van 't sluiten van een bestand met Spanje, was het namelijk wenschelijk, dat de Compagnie vóór het tot stand komen daarvan op een zoo groot mogelijk aantal handelspunten in de Oost beslag legde. Daarom moest dadelijk van Japan werk worden gemaakt, zoodat de beide schepen via Patani dit land moesten bezoeken. Ze zouden dan tevens kunnen beproeven, een Portugeesche kraak, die, naar Verhoeff vernomen had, te Macao gereed lag om naar Japan uit te varen, te vermeesteren, doch dit was geen hoofdzaak. 10 of 11 Mei uit Johor vertrokken, kwamen de schepen den $27^{\text {en }}$ of $28^{\text {en }}$ daaraanvolgende in Patani aan. De sloep was er toen reeds drie dagen, daar men haar had vooruitgezonden om order te geven, het eventueele cargasoen, voor Japan geschikt, gereed te houden. Lang hebben de schepen er niet getoefd: men laadde wat ruwe zijde, lood en peper in om, als de kraak niet veroverd mocht worden, ,enigen schyn, van dat wy daer begeerden te handelen ende een comptoir te stichten" te laten blijken. 10000 realen van achten werden te Patani achtergelaten, waarvan er 5000

1) Hij had deelgenomen aan den tocht van Mahu en De Cordes. In Japan trad hij als scheepsbouwer voor den keizer op, gaf hem les in wiskunde en geraakte zeer bij hem in eere.

2) Zie De Jonge III, p. 75 v.

3) De sloep van't schip Delft.

Verh. dl. I. 
al dadelijk aan de koningin, van wie men geld had geleend, moesten worden terugbetaald. Hierop voeren op 30 Mei of 1 Juni de Roode Leeuw met Pijlen en de Griffioen naar Japan ${ }^{1}$ ). De leiding van dezen gewichtigen tocht berustte bij de opperkooplieden Nicolaas Puyck en Abraham van den Broecke, welke laatste ons kantoor te Johor bestuurd had ${ }^{2}$ ); Verhoeff had hem echter als zoodanig vervangen door Jacques Obelaer.

De beide schepen kwamen 1 Juli aan voor Nagasaki, waar de opvarenden tot hun teleurstelling vernamen, dat de kraak juist twee dagen daarvoor veilig in dezelfde plaats was binnengeloopen. Tegenover die teleurstelling stond echter een groot succes. De beide opperkooplieden, bijgestaan door Melchior van Santvoort als tolk, wisten van den keizer vrijheid van handel op alle Japansche havens te verkrijgen. Dit was voor de Compagnie het begin van uiterst belangrijke handelsbetrekkingen. Ongelukkig was de hoeveelheid goederen, die men in Japan kon achterlaten, zoo ruwe zijde, lood en peper, maar gering. Men zou echter trachten, hiermede de zaken gaande te houden, totdat in 't volgende jaar nieuwe Compagniesschepen een groot cargasoen zouden komen brengen, wat zoowel uit handelsoogpunt als ook terwille van ons prestige in 't land zeer gewenscht was. In Hirado $^{3}$ ) werd de Nederlandsche factorij gevestigd, met als opperkoopman Jacques Specx, die ondierkoopman op de Griffioen was geweest. $\mathrm{Na}$ aldus de zaken tot hun genoegen te hebben geregeld, vertrokken Puyck en Van den Broecke op 2 October met de beide schepen wederom uit Hirado.

Men kan zich de voldoening van Sprinckel en zijn metgezellen voorstellen, toen de Japansvaarders, die ongeveer een maand later ${ }^{4}$ ) weer te Patani terugkwamen, verslag uitbrachten over de gunstige ontvangst, die ze in Japan hadden genoten, en het daar behaalde succes. Het kwam er nu op aan, onzerzijds zoo groot mogelijk voordeel uit deze nieuwe handelsgelegenheid te trekken en ook den keizer niet teleur te stellen in zijn verwachtingen. Daar het nu bekend was, dat Cambodja, in 't Zuiden van Achter-Indië gelegen, hertevellen en roggevellen opleverde, twee artikelen, die in Japan zeer ,getrokken" waren ${ }^{5}$ ), werd besloten, dat men zou trachten, ook daar een kantoor

1) Er was besloten, dat de sloep zich naar Ternate zou begeven.

2) Zie p. 37 .

3) In de Nederlandsche brieven Firando genoemd.

4) De Roode Leeuw met Pijlen kwam 30 Oct., de Griffioen 7 Nov.

5) Hertevellen werden later op Formosa door de Nederlanders bij honderd- 
te stichten. Henricq van Raeij, onderkoopman op de Roode Leeuw met $\mathrm{Pijlen,} \mathrm{werd} \mathrm{bestemd} \mathrm{voor} \mathrm{den} \mathrm{rang} \mathrm{van} \mathrm{opperkoopman} \mathrm{van} \mathrm{deze}$ factorij. Hij zou daarheen met den assistent Hans Baillij vertrekken, zoodra het noodige kapitaal ervoor uit Bantam in Patani zou zijn aangekomen. Naar Bantam schreef Sprinckel derhalve, dat in April 1610 zoo mogelijk een som van 60 à 80000 realen van achten moest worden gebracht, alsmede goederen, die in Patani dienstig waren. Te meer was zulk een kapitaalsversterking wenschelijk, daar men nog geld aan de koningin schuldig was en men tegen de komst der Chineesche jonken geld voor de zijdeïnkoop noodig zou hebben. Verder zou eenig machtsvertoon van schepen een goed tegenwicht kunnen zijn tegen de Portugeesche schepen uit Malakka, die buitengewoon dreigend optraden, zoowel tegen de inwoners van Johor als die van Patani, en een groote ,beroerte” in laatstgenoemde plaats teweegbrachten.

Er werd besloten, dat de Roode Leeuw met Pijlen en de Griffioen onderweg naar Bantam Johor, dat reeds lang door de Portugeezen in 't nauw gebracht was, zouden aandoen, om dan over den toestand aldaar in Bantam te kunnen rapporteeren. Nadat den $13^{\text {en }}$ November de Griffioen met peper was volgeladen en eenige dagen daarna de Roode Leeuw ook zijn last in had, vertrokken de Japansvaarders op 21 November naar het Zuiden. Het Portugeezengevaar bleek nog erger, dan men verwacht had: onderweg kregen ze bericht, dat een bootsgezel, Jan Janssen van Bremen, met een jonk met brieven naar Johor en Bantam gezonden, omstreeks Pahang door de Portugeezen gevangen genomen was. $\mathrm{Bij}$ Johor gekomen vond men den koning reeds in onderhandeling met de Portugeezen ${ }^{1}$ ). In Januari 1610 ankerden de Roode Leeuw en de Griffioen voor Bantam, waar ze aldus zoowel slechte als goede tijding te brengen hadden.

Met het stichten der factorij in Cambodja ging 't echter niet naar wensch: de daarvoor zoo noodige kapitaalsversterking kwam niet. In Juni 1610 beklaagt Sprinckel zich hierover op bitteren toon bij l'Hermite: met zoo schoone mogelijkheden en zoo weinig steun is het voor hem en de zijnen ,een miserabel leven”, en welk een indruk moest men in Japan wel van de Nederlanders krijgen! „Wy syn al

duizenden voor Japan gekocht (Muller: Onze Vaderen in China, Gids 1917 I, p. 330).

1) 16 Oct. 1610 werd de vrede gesloten tusschen beide partijen. De Nederlanders schijnen echter in hun factorij van Batosauwer ongemoeid te zijn gelaten. 
groot van belofte ende begrijp, maer luttel in 't effectueren". De zending van Van Raeij naar Cambodja moest worden opgegeven, nadat hij vruchteloos tot in September 1610 op geld uit Bantam had gewacht $^{1}$ ).

Terwijl aldus in 't Westen geldgebrek zich op de pijnlijkste wijze deed gevoelen, speelde zich in 't Oosten de groote worsteling af om 't bezit van de Molukken. Hierop vooral was de andacht van bewindhebbers gevestigd; waren eerst de specerij-eilanden voorgoed voor de onzen gewonnen, dan zou ook voor de bevestiging en het rendabel maken der Westelijke kantoren gezorgd kunnen worden. Het treurige

1) Vgl. over den tocht der Japansvaarders: Van Dijk: Japan, p. 15 v.; De Jonge II, p. 219 v., III, p. 81 v., p. 89 v., p. 137 en bij1. XXVII ${ }^{\text {; }}$ Tiele Eur. 4 VIII, p. 89 v.; 93, 109 v.; Groeneveldt, p. 47; J. E. Elias : Het voorspel van den eersten Engelschen oorlog II (Den Haag, 1920), p. 15 v.; Netscher: De Nederll. in Djohor en Siak, p. 16, 26, 27; MacLeod I, p. 73, 75 v., 84; Heeres: Corpus Dipl. I, p. 69 v.; Calendar of State Papers, East Indies, China and Japan 1513-1616, London 1862, p. LXVIII; Nachod, p. 107 v. (Nachod zegt ten onrechte, dat Sprinckel als opperkoopman op de Erasmus is geweest. Dit moet zijn: op de Mauritius, vgl. p. 36); Wieder I, p. 69 v., III, p. 39 v.; Res. XVII in hun vergad. v. 3 Oct. 1607; Journaal, gehouden op 't schip de Griffioen, 27 Nov. 1607-14 Febr. 1610 (Kol. aanww. 1910, XV, n 2); Copiebrief van Victor Sprinckel aan den keizer van Japan, bedoeld in noot 3 van pag. 31; Copiebrief van Hendrik Janssen aan .Lambart Jacobss. (Heyn?) in Siam, Patani, 23 Mei en 8 Juni 1609 (Copieb. H. J.); Resolutie van de breede raden der schepen Roode Leeuw met Pijlen en Griffioen benevens de raden van de loge te Patani, Patani, 28 Mei 1609; Res. v. pres. en breede raden op 't schip de Roode Leeuw met Pijlen, voor 't eil. Tingoraon (? de naam eenigszins onduidelijk), 29 Mei 1609; Res. v. breede raden op 't schip de Roode Leeuw met Pijlen, Firando, 20 Sept. 1609; Res. van raden van 't schip de Vereenigde Leeuw met Pijlen en de Griffioen, Patani, 16 Nov. 1609; Res. in 't schip de Vereenigde Leeuw, Patani, 20 Nov. 1609; Res. van 't college v. beide schepen, op 't schip de Griffioen vergaderd, bij 't eil. Tiomon, 1 Dec. 1609; Res., liggende met de beide schepen voor de rivier van Johor, 4 Dec. 1609; Victor Sprinckel aan Lambert Jacobsz. Heyn in Ajudhja, Patani, 30 Jan. 1610; Copiebrief van Lambert Jacobsz. Heyn aan Victor Sprinckel, Siam, 17 Mt. 1610; Copiebrief van Lambert Jacobsz. Heyn aan Jacques Specx, Siam, 28 Mt. 1610; Victor Sprinckel aan Lambert Jacobsz. Heyn in Ajudhja, Patani, 16 Mei 1610; Victor Sprinckel aan Jacques 1'Hermite te Bantam, Patani, 16 Juni 1610; Victor Sprinckel aan Lambert Jacobsz. Heyn in Ajudhja, Patani, 1 Aug. 1610; Henricq van Raeij (aan beww.?), in 't jacht de Pauw ter reede van Patani, 8 Oct. 1610; Copiebrief van Victor Sprinckel aan beww. kamer Delft, Patani, 31 Oct. 1610; Jacques 1'Hermite de Jonge aan beww., Bantam, 10 Nov. 1610; Copie-res. van Pres. en raden, Jacatra, 22 April 1617 (Col. Coen III, p. 395 v.); Copiebrief van Victor Sprinckel aan Lambert Jacopssen (Heyn?) (Copieb. V. S.); Memorie voor Pieter Willemsz. Verhoeff c.s. (Kol. Aanw. 1910, XV, $\mathrm{n}^{\circ} 1$ ); Memorie op de koopmanschap (Kol. Aanw. 1910, XV, $\mathrm{n}^{\circ} 1$ ); Ordonnantie en instructie voor de kooplieden e.a. personen, die in Indië aan land zullen blijven (Kol. Aanw. 1910, XV, nº 1). 
lot van admiraal Verhoeff evenwel, die in 1609 op de Banda-eilanden verraderlijk werd vermoord, en het daarop volgende sneuvelen van zijn vice-admiraal Wittert in de Philippijnen, deze dingen brachten schrik en ontmoediging over geheel Indië, en ook ons kantoor in Patani ondervond den nadeeligen terugslag ervan. Sprinckel, die schepen met kapitaal uit de Molukken had verwacht, gaf nu vrijwel de hoop op, van dien kant steun te ontvangen, ja, hij rekende met de mogelijkheid, dat misschien schepen in zoo berooiden toestand op de reede van Patani zouden verschijnen, dat hij ze voor de reis naar patria van voedsel zou moeten voorzien; hij wendt zich daarom bij voorbaat tot Lambert Jacobsz. Heyn in Ajudhja: ,sal seer noodich weesen", aldus schrijft hij hem, ,dat ghy aldaer een 100 verckens laet slaen ${ }^{1}$ ) ende die in potten souten", om die dan zoo snel mogelijk naar Patani te zenden. Sprinckel's sombere voorgevoelens werden bewaarheid; het jacht de Pauw en de sloep van 't schip Delft, die aan de nederlaag van vice-admiraal Wittert ternauwernood waren ontsnapt, zetten in desolaten toestand koers naar Patani. De sloep, beter bezeild dan de Pauw, werd vooruitgezonden, om aan Sprinckel zoo spoedig mogelijk het bericht van de nederlaag te brengen, opdat men dan in Patani dadelijk maatregelen kon nemen tegen een mogelijken onaangenamen terugslag bij de inlanders. Den $8^{\text {en }}$ Mei 1610 bereikte de sloep Patani, waarna op den $29^{\text {en }}$ van die maand ook het jacht de Pauw arriveerde ${ }^{2}$ ).

We kunnen de wijze niet bewonderen, waarop Sprinckel de vluchtelingen uit de Philippijnen ontving. Zijn stemming is er in de eerste plaats een van wrevel, dat door de opvarenden van de Pauw noch voldoende kapitaal, noch ook koopmanschappen werden aangebracht. ,'t Syn een hoop cale neten”, aldus bericht hij naar Siam, ,zij en hebben niet een droppel wyns inne". Toch mocht hij eigenlijk van geluk spreken; de koopman van de Pauw, Peter Segers geheeten, ontriefde zich door al het geld, dat hij te missen had, zijnde meer dan 13000 realen van achten, aan Sprinckel over te leveren, opdat althans de schulden, die men had, geld, dat van de koningin geleend was, tollen enz., ten deele konden worden voldaan. 8000 realen bleef

1) D.i. slachten.

2) Onjuist moet de mededeeling zijn van MacLeod I, p. 84, dat de Pauw $25 \mathrm{Mei}$, en de sloep den $29^{\text {en }}$ aankwam. Volgens Van Dijk: Japan, p. 31 v., zou de Pauw ook reeds in Sept. 1609 in Patani gekomen zijn. Dit kan bezwaarlijk juist zijn, daar den $22^{\text {en }}$ van die maand de Pauw eerst van Ternate tegen de Spanjaarden uitvoer (zie De Jonge III, p. 102 v.). 
het kantoor nog aan de koningin schuldig. Er werd besloten, dat de Pauw, die vertimmerd moest worden, tot 't laatst van den Westmoesson in Patani zou blijven, dat daarentegen de sloep vooruit zou varen naar Bantam, onderweg zoo mogelijk Pahang aandoende om poolshoogte te nemen, of daar soms een Portugeesche of een Hollandsche vloot in de buurt was; in 't laatste geval moest men zijn landgenooten opzoeken en het nieuws, dat hun dienstig kon zijn, overbrengen. Vervolgens zou men doorvaren, in Bantam l'Hermite van alles op de hoogte stellen, en hem verder verzoeken, geld naar Patani te zenden, dat daar voor den Chineeschen handel dringend noodig was. Den $18^{\text {en }}$ Juni vertrok de sloep aldus naar 't Zuiden. De voorgenomen reis mislukte evenwel door tegenwind. Men zag zich tenslotte genoodzaakt, de haven van Patani weer op te zoeken, en kwam daar aan op 13 of 18 Augustus.

Tijdens de afwezigheid van de sloep had Sprinckel tot zijn vreugde nieuw bezoek gekregen, namelijk van het schip Delft, dat door admiraal Van Caerden uit Ternate naar Patani was gezonden om daar zijn lading in te nemen en tevens order te geven, dat zoo spoedig mogelijk provisie met het jacht de Pauw naar de Molukken moest worden gezonden. Bijzonder aangenaam was het, dat de opperkoopman van de Delft, Jan van der Heesen, het kantoor Patani voorzag van 44000 realen, welke som natuurlijk allereerst dienst moest doen voor verdere schuldaflossing.

Aan de lastgeving van Van Caerden werd voldaan: met een lading arak, spek en andere levensmiddelen werd de Pauw op 10 October naar Ternate gezonden, met order, onderweg Makassar aan te doen, teneinde daar nog een hoeveelheid rijst in te slaan.

De koopman van het jacht, Peter Segers, was echter in Patani gebleven, daar hier dringend behoefte aan geschikte leggers was. Ten eerste waren namelijk eenige personen, die voor den dienst in Patani bestemd waren geweest, gestorven, en verder koesterde Sprinckel het verlangen, gelicht te worden. De dienst verdroot hem; hij vond, dat zijn factorij voortdurend verwaarloosd werd, en dat zijn maandgeld (f 54) al te karig was voor een zoo verantwoordelijken post. Daar echter Van der Heesen geen lastgeving had, hem van zijn ambt te ontheffen, moest hij, al was ook zijn diensttijd van drie jaren geëindigd, op nadere gelegenheid wachten. Peter Segers nu, die als zijdekenner juist in Patani goed op zijn plaats was, zou, zoo lang Sprinckel nog in Patani vertoefde, onder diens leiding ,de 
coustume van den lande, de kennisse der coopl. ${ }^{1}$ ) ende oock mede de tale leeren".

Het jaar 1610 was voor Sprinckel ook wel heel moeilijk. Bij zijn reeds genoemde bezwaren kwamen nog herhaaldelijk gevallen van ongezeglijkheid van 't scheepsvolk voor, die levendig aan 't beruchte bezoek van de Gelderland herinnerden ${ }^{2}$ ). Het scheen wel, of de geest van verwarring, die in 't Oosten na den moord op Verhoeff bij de schepelingen van zijn vloot was ontstaan, zich in Patani voortzette. Drie opvarenden van de Pauw en de sloep maakten zich schuldig aan insubordinatie, vier schepelingen van de Pauw deserteerden, en werden van Patani uit vruchteloos tot Sangora nagezet; men vernam, dat ze van plan waren, naar Siam te varen; erger nog werd het met 't schip de Delft: aan boord heerschte de grootste losbandigheid, en aan land speelden de schepelingen danig de beest en deden den inlanders zoo grooten overlast aan, dat de reputatie der Nederlanders er weer allesbehalve door bevorderd werd. Twee Spanjaarden uit het schip, die van Ternate waren komen overloopen, pleegden ten tweeden male verraad en deserteerden. Men moet zich al deze bijzonderheden voor oogen stellen om te begrijpen, hoe moeilijk het was, in deze voor de Compagnie nog zoo onzekere tijden ergens een factorij tot bloei te brengen en winsten te doen afwerpen.

Ondanks alle ongunstige omstandigheden gelukte het, in hoofdzaak het schip Delft te Patani vol te laden: omtrent 2000 baren peper van verschillende, b.v. Jambische, herkomst werden ingescheept, terwijl de rest van de lading bestond uit benzoë, rhabarber ${ }^{3}$ ), gitta mondo ${ }^{4}$ ), cardamon ${ }^{5}$ ), zijde en zijdewaren, alsmede een partij fijne porseleinen schotels, de geheele lading ter waarde van $\pm f 112000$. De bedoeling was, dat de nog overgebleven ruimte in Johor met peper zou worden gevuld. Van groot belang is het, dat Hendrik Janssen, die de Compagnie geruimen tijd trouw had gediend, en over wien ook Sprinckel met lof spreekt, met de Delft mee naar Bantam en vandaar naar patria zou vertrekken, daar hij om zijn verlossing ver-

1) Waarsch. voor : kooplieden.

2) Vgl. p. 43 v.

3) Als laxans gebruikte wortel, uit China afkomstig, zie Van Dam-Stapel, II I, gloss. i. v.

4) Mondo kan ik niet verklaren. In gitta zullen we stellig getah (uit getah pertja) hebben te zien.

5) Welriekende specerij, vulgo paradijskorrels, zie Van Dam-Stapel, I I, gloss. i. v. 
zocht had, wat Sprinckel hem niet had kunnen weigeren, daar zijn verbonden tijd om was.

Op 3 November of kort daarna moet de Delft, waarschijnlijk van de sloep vergezeld, naar Bantam vertrokken zijn; zij kwam daar op 15 December aan. Hendrik Janssen zou echter zijn voorgenomen reis naar 't vaderland niet aanvaarden. Dit hing hiermee samen, dat Pieter Both, de eerste gouverneur-generaal, die op 19 December eveneens in Bantam aankwam, zoo weinig kooplieden uit Holland had meegebracht, dat men ,alsulcke, die men daer toe can verwilligen”, moest blijven gebruiken. En het behoud van Hendrik Janssen voor 't kantoor van Patani zou wel van bijzonder gewicht zijn, ,aengesien d'experientie van de taele" en zijn kennis van de "costume" dier streken, ,,vermits daer 8 a negen jaren gewoont hadde". Zoo wisten de G.-G. en zijn raad hem ertoe te brengen, zich wederom voor drie jaren te verbinden als koopman en plaatsvervanger van Victor Sprinckel, op een gage van f 60 per maand, met 't vooruitzicht, dat hij, zoo hij den handel tot bijzonder voordeel van de Compagnie zou bedrijven, verbetering zou genieten ${ }^{1}$ ). Als onderkoopman bij hem werd Matthijs de Mere aangesteld. Verder zou Pieter Hendrikss. van Vlissingen ${ }^{2}$ ), in Patani bekend en ,de spraecke cunnende”, toen blijkbaar evenals Hendrik Janssen ook in Bantam zijnde, met dezen mee gaan, om onder hem te dienen ${ }^{3}$ ).

Ten tweeden male begaf zich dus Hendrik Janssen naar Patani, en wel op het jacht de Brak, dat tot de vloot van Pieter Both behoorde. Het jacht kreeg 40000 realen van achten aan boord, om daarmee de kantoren van Patani en Johor voorloopig te helpen, in af wachting van een schip, dat spoedig zou volgen. Wegens de geringe weerbaarheid van de Brak durfde men er geen grooter kapitaal mee te zenden. Behalve voor Patani was deze tocht ook voor Japan van belang, waar zich in 1610 geen enkel Nederlandsch schip had vertoond, hetgeen na het bezoek van de Roode Leeuw met Pijlen en de Griffioen in 1609 aldaar een eenigszins pijnlijken indruk had gemaakt. Daarom moest nu de Brak in Patani Segers aan boord nemen, die dan in Hirado de banden tusschen beide volken moest versterken. Hij kon daarvoor beschikken over een lading lakens,

1) De resolutie dienaangaande is van 1 Jan. 1611. In een brief van 5 Dec. 1612 schrijft Segers, dat Janssen zich op 30 Jan. opnieuw heeft laten aannemen. Misschien had hij dus zoo lang bedenktijd gevraagd.

2) Vgl. p. 45.

3) In welken rang, is mij niet bekend. 
karsaaien ${ }^{1}$ ) en olifantstanden, die de Brak uit Bantam meekreeg. Hij moest zich op de hoogte stellen van de toestanden in genoemde Japansche plaats, om bij zijn terugkeer aan den gouverneur-generaal rapport over een en ander uit te brengen. Vroeg in 1611 moet de Brak vertrokken zijn. In Patani ging Hendrik Janssen aan land, en scheepte Segers zich in ${ }^{2}$ ), naar 't schijnt in Juli 1611, en wel met een aanbevelingsbrief van den reeds genoemden William Adams ${ }^{3}$ ), die ,zoo hoog als eenig prins of potentaat van 't land bij den Keizer gezien was". $\mathrm{Na}$ 't volvoeren van zijn lastgeving in Japan keerde Segers met de Brak terug naar Patani. Hier begaf zich Victor Sprinckel bij hem aan boord; ze anvaardden de reis naar Bantam, waar ze, na een oponthoud van tien dagen te Johor, op 8 Januari 1612 arriveerden.

In Patani was dus met het vertrek van Victor Sprinckel in 1611 een belangrijke periode geëindigd. Hoe moet ons oordeel over den factorijhouder ten slotten luiden? Heeres ${ }^{4}$ ) getuigt onverdeeld gunstig over hem: hij prijst Sprinckel als uitmuntend koopman, voorzichtig politicus, in humaniteit en waardeering van de inlanders verre boven bijna al zijn tijdgenooten uitstekende. Zonder dit oordeel bepaald te willen bestrijden, moet ik toch ter aanvulling van het door Heeres naar voren gebrachte er op wijzen, dat de lof over Sprinckel in diens tijd niet onverdeeld was. Het schijnt me, dat hij, zooals trouwens velen, zijn post te belangrijk vond en in een lichtvaardig optimisme mogelijkheden voorspiegelde, die moeilijk waren te verwezenlijken. In één opzicht althans is dit wel zeker. In een vertoog aan de bewindhebbers heeft Sprinckel de geschiktheid van Patani betoogd om voor de levensmiddelenvoorziening van de Molukken dienst te doen. Jan Pietersz. Coen betwijfelt de juistheid van deze meening, Hendrik Janssen komt er tegenop, en Reael qualificeert Sprinckel's vertoog als ,gantsch ende gader abusyff”, ja, hij noemt hem een grootspreker. Dat Segers slordigheid in boekhouding bij Sprinckel constateert, dat Hendrik Janssen een nalatigheid in de correspondentie van zijn vroegeren chef meldt, en hem bij een andere gelegenheid van grof liegen beschuldigt, deze dingen kunnen op

1) Een grof wollen stof.

2) Volgens Van Dijk: Japan, p. 34, zou hij hierbij vergezeld zijn van Jacques Specx. Van Dijk beroept zich hierbij op Begin ende Voortgangh, maar citeert de daaruit bedoelde plaats niet.

3) Zie p. 49.

4) Heeres: Hendrik Janssen, p. 107 v. 
kleinigheden of op misverstanden berusten, waaraan misschien een zekere ,jalousie de métier” niet vreemd is.

Hoe dit alles zij, twee dingen staan vast: Sprinckel heeft ' $t$ in Patani niet gemakkelijk gehad, en verder: de kolonie tot bloei gebracht heeft hij niet: toen hij na zijn vele teleurstellingen zijn post verliet, zat het kantoor diep in de schuld, zoowel bij de koningin als bij anderen, samen tot een bedrag van 22000 realen. Dat echter eindelijk een centraal bestuur in Indië was ingesteld, dat de bewindhebbers aldus hun vasten wil getoond hadden, het begonnen werk met kracht voort te zetten, daarin kon ook voor onze loge in Patani een belofte liggen. En de ervarene Hendrik Janssen zou wel de man zijn om van iedere gunstige wending van 't lot dadelijk op doeltreffende wijze gebruik te maken ${ }^{1}$ ).

1) Vgl. over 't bovenstaande: Valentyn III IIc, p. 91 (volgens Val. zou Sprinckel zich nog in 1616 in Patani bevonden hebben. Dit blijkt volgens hem uit de papieren van de Comp. Ik zou geneigd zijn, de oorzaak van deze vergissing te zoeken in een plaats van Beg. ende Voortg., Journaal van Roelof Roelofsz, p. 16); Van Dijk: Japan, p. 31 v.; Heeres: Hendrik Janssen, p. 112 v.; Nachod, p. 141 v.; MacLeod I, p. 84, 102; Victor Sprinckel aan Lambert Jacobsz. Heyn te Ajudhja, Patani, 30 Jan. 1610; Res. over 't zeilen uit de „Maniles” naar Patani, onderteekend door Gijsbert Gijsberzoon, Peter Segers e.a., 25 April 1610; Copiebrief van Peter Segers uit 't jacht de Hazewind aan Victor Sprinckel, 18 Mei 1610; Victor Sprinckel aan Lambert Jacobsz. Heyn in Ajudhja, Patani, 6 Juni 1610; Copie-res. van 't kantoor van Patani en die van 't jacht de Pauw met de sloep van 't schip Delft, Patani, 8 Juni 1610; Attestatie voor den raad van Patani, Patani, 12 Juni 1610; Attestatie Patani 15 Juni 1610; Victor Sprinckel aan Jacques l'Hermite te Bantam, Patani, 16 Juni 1610; Copiebrief van Paulus van Caerden aan beww., fort Oranje op Ternate, 17 Juni 1610; Copiebrief van Peter Segers aan l'Hermite, Patani, 18 Juni 1610; Victor Sprinckel aan Lambert Jacobsz. Heyn in Ajudhja, Patani, 1 Aug. 1610; dezelfde aan denzelfde, Patani, 20 Aug. 1610; Copiebrief van Lambert Jacobsz. Heyn aan Victor Sprinckel, Siam, 20 Sept. 1610; idem aan denzelfde, Siam, 5 Oct. 1610; Henricq van Raeij aan (beww.?), in 't jacht de Pauw, op de reede van Patani, 8 Oct. 1610; Copiebrief van Jacques l'Hermite aan den adm. Van Caerden, Bantam, 23 Oct. 1610; Copiebrief van Victor Sprinckel aan beww. v. kamer Delft, Patani, 31 Oct. 1610; Een brief aan beww. uit Patani, 1 Nov. 1610; Copiebrief van Peter Segers aan 't kantoor te Bantam, Patani, 2 Nov. 1610; Victor Sprinckel aan Jacques l'Hermite te Bantam, Patani, 2 Nov. 1610; Peter Segers aan beww. te Amst., Patani, 3 Nov. 1610; dezelfde aan dezelfden, Patani, 3 Nov. 1610; Jacques l'Hermite de Jonge aan beww., Bantam, 10 Nov. 1610; Copieress. Both en zijn raad, 20 Dec. 1610-13 Juli 1611; Copiebrief uit naam der beww. aan Peter Segers in Patani, Amsterdam, 17 Dec. 1611; Peter Segers aan Hendrik Janssen te Patani, Bantam, 20 Mt. 1612; Victor Sprinckel aan Hendrik Janssen, Bantam (er staat foutief Patany boven), 20 Mt. 1612; Peter Segers aan beww. kamer Amst., Bantam, 5 Dec. 1612; Hendrik Janssen aan Jacop die Schot te Bantam, Patani, 12 Oct. 1613; Hendrik Janssen aan beww. te Amst., Patani, 20 Oct. 
Nog vóór Sprinckel's vertrek uit Patani was ook zijn ondergeschikte Lambert Jacobsz. Heyn, die onder zijn auspiciën de zaken in Siam voor de Compagnie behartigd had, van zijn post vertrokken. $\mathrm{Na}$ het vertrek der beide onruststokers Tonneman en Van de Perre ${ }^{1}$ ) was er een rustiger tijd voor hem angebroken, waarin hij gesteund werd door Jan Dircxss. Roekoe ${ }^{2}$ ) en Isack Willemsen. Wanneer de laatste in Siam is gekomen, is mij onbekend; wat Roekoe betreft, deze is 18 Maart 1609 als brenger van een cargasoen uit Patani met een brief van Sprinckel bij Heyn gekomen ${ }^{3}$ ).

Lastig was voor Heyn de verhouding tot den koning van Siam. Herhaaldelijk liet deze den Hollander bij zich onthieden, niet begrijpende, waarom de "fraijecheeden”, waarom hij had verzocht ${ }^{4}$ ), hem maar steeds niet gegeven werden. Zorg toch, zoo schrijft Heyn op 20 Sept. 1610 aan Sprinckel, dat ge zoo spoedig mogelijk eenige Hollandsche fluweelen, satijnen, prenten en andere fraaiigheid zendt, die zoo uitstekend geschikt zijn ,om 't hert van den coninck meerder tot ons te chrijgen". Wat Sprinckel echter zelf niet had, kon hij onmogelijk zenden. Nog een andere reden droeg bij tot de ongeduldige stemming van den koning: hij werd hoe langer hoe ongeruster over het aldoor uitblijven van zijn gezanten, en wenschte in dit opzicht steeds inlichtingen van Heyn, welke deze niet kon verstrekken. Terwijl de telkens weer teleurgestelde vorst in de meening verkeerde, dat de Nederlanders bij den handel op zijn land de grootste voordeelen konden hebben, was het enthousiasme van de Oostindische Compagnie in dit opzicht reeds aan 't bekoelen; de bewindhebbers vonden blijkbaar noch voor den Japanschen handel, noch voor den Chineeschen, noch ook om zich zelfs wil Siam meer van overwegend belang: ja, op 11 September 1610 besloten Heeren XVII, aan Gouverneur-Generaal en Raad in overweging te geven, het kantoor in Siam, als kostbaar en weinig profijt opleverend, te lichten.

1614; Copiebrief van J. P. Coen aan Hendrik Janssen, Bantam, 10 Juni 1615 (Col. Coen II, p. 10 v.); Copiebrief van Hendrik Janssen aan 't kantoor Bantam, Patani, 15 Nov. 1615; Copiebrief van Laurens Reael aan beww. te Amst., Ternate, 11 Juli 1616; Hendrik Janssen aan beww. te Amst., Patani, 25 Oct. 1616; de extract-brief van Van den Broecke bedoeld op p. 23 noot 2; Ordonnantie en instr. voor de kooplieden e.a., die in Indië aan land zullen blijven (Kol. Aanww. 1910, XV, $\mathrm{n}^{\circ} 1$ : instructie reis Verhoeff).

1) Zie p. 46.

2) Zie p. 37.

3) Jacob Adriaensen (p. 45 en 47) is in 1609 van Siam naar Patani gegaan, hoogstwaarschijnlijk in Mei.

4) Zie p. 47. 
In 't begin van 1610 verloor Heyn tot zijn spijt zijn beide helpers Jan Roekoe en Isack Willemsen. Dezen hadden hun verlangen te kennen gegeven, het Siameesche kantoor te verlaten; nadat nu door Sprinckel uit Patani Jacob Adriaensen en zekere Ellert Ellertsen naar Ajudhja waren gezonden om hen, indien ze bij hun wensch bleven, te vervangen, arriveerden ze 9 Mei 1610 inderdaad in Patani. Ook Heyn had in Maart 1610 aan Sprinckel verzocht, van zijn post te worden ontheven. Hij liet evenwel doorschemeren, dat, als Sprinckel en zijn raad zouden kunnen besluiten tot verhooging van zijn salaris, hij nog wel geneigd zou zijn, een paar jaren in Siam te blijven. Hoewel hij in September nog in denzelfden geest aan Sprinckel schreef, kreeg hij de verlangde verbetering niet; in Patani werd anders beschikt : Heyn moest, zoo werd hem 26 October geschreven, per eerste gelegenheid terugkomen, terwijl als zijn opvolgers in gelijken rang twee personen het kantoor van Siam zouden besturen, namelijk Cornelis van Nieuwenroode, die als juwelier met de vloot van Verhoeff was uitgevaren, en Marten Houtman. Als we in aanmerking nemen, dat Van Nieuwenroode ook bekwaamheid had in 't goudsmidsvak en een leertijd in Duitschland en Frankrijk had doorgemaakt, dat verder Marten Houtman vier jaren in Patani had gelegen, en aldus met den handel in die streken zeer goed op de hoogte kon zijn, dan ziet men, dat de koning van Siam toch nog niet kon klagen, dat zijn rijk geheel door de Compagnie werd verwaarloosd. Ook wat het gezantschap betreft kwam er eindelijk vooruitgang. De Siameesche ambassade, die gehoor had gehad bij prins Maurits, en eenige Hollandsche steden had bezocht ${ }^{1}$ ), vertrok namelijk met de vloot van Pieter Both weer naar Indië, waarna op 11 Januari 1611 door Both en zijn raad werd geresolveerd, dat de gezanten met de $\mathrm{Brak}^{2}$ ) naar Patani zouden vertrekken, om dan na aankomst aldaar de reis naar Siam op een jonk voort te zetten, begeleid door iemand uit de loge van Patani $\left.^{3}\right)^{4}$ ).

1) Volgens Van Dam I II, p. 309, werden aan „den” ambassadeur (hiermee wordt zeker de hoofdpersoon bedoeld) eenige geschenken meegegeven ,om door faveur van denselven den handel in China te verkrygen".

2) Zie p. 56 .

3) Onjuist is dus, dat, zooals Dr. H. P. N. Muller beweert (Het land van den Witten Olifant enz., Vragen des Tijds 1912, I, p. 136), de gezanten in 1609 in Siam terugkwamen.

4) A1 blijven er ook onzekerheden bestaan omtrent onze betrekkingen met Siam van $1609-1613$, toch is volkomen onjuist, wat we lezen in het "Overzicht" (bedoeld op p. 7 noot 2), p. 411 v., dat wegens bronnengebrek over dezen tijd niets met zekerheid bekend is. Vgl. over de kwesties aangaande Siam: 
Is uit het vorige deel van dit hoofdstuk gebleken ${ }^{1}$ ), dat Patani tijdens 't bewind van Ferdinand Michiels van belang was voor onze betrekkingen met Borneo's Westkust, ook na diens dood bleef dit verband nog bestaan. Op 26 October 1607 namelijk werd door Hendrik Janssen Pieter Aertss., die met den ongelukkigen Hans Roeff in Juli van dat jaar uit Soekadana gekomen was, wederom daarheen gezonden, met een cargasoen van ruim $\mathrm{f} 4160$, om dit daar te besteden, en zich daarna naar Bantam te begeven. Hij werd op dezen tocht vergezeld door een zekeren Albert Rutgers. Pieter Aertss., nog jong, en blijkbaar niet tegen zijn nieuwe verantwoordelijkheid opgewassen, heeft door deze reis zijn reputatie niet verbeterd, integendeel. Nadat hij 13 November in Soekadana was aangekomen, schijnt hij zich veel te eigenmachtig te hebben gedragen. Albert Rutgers, die 22 Februari 1608 door hem naar Bantam gezonden werd, klaagde er over, dat Aertss. zich niet naar de instructie van Hendrik Janssen had willen gedragen, met wien hij zich op een lijn stelde, terwijl zijn kennis van den diamanthandel zoo gering was, dat hij bij den inkoop der steenen niet op zijn eigen oordeel durfde te vertrouwen en aan anderen om voorlichting moest vragen. In plaats van naar Bantam te gaan, negeerde Aertss. dit punt van zijn lastgeving; hij liet voor den nog nauwelijks gevestigden handel een huis bouwen, en leidde een zoodanig leven, dat Hendrik Janssen, die in Patani altijd tevreden

de reeds geciteerde plaats van Muller; Van Dam I II, p. 309 en II I, p. 342; het genoemde „Overzicht”, p. 411; MacLeod I, p. 99, 102; Copiebrief van Hendrik Janssen aan Lambart Jacobss. (Heyn?) in Siam, Patani, 23 Mei en 8 Juni 1609 (Copieb. H. J.) ; Copiebrief van Lambert Jacobsz. Heyn aan Victor Sprinckel, Siam, 13 Sept. 1609; idem aan denzelfde, Siam, 9 Nov. 1609; Victor Sprinckel aan Lambert Jacobsz. Heyn in Ajudhja, Patani, 30 Jan. 1610; Opgaaf van cargasoen, door Victor Sprinckel naar Siam gezonden, Patani, 1610 Jan.; Copiebrief van Lambert Jacobsz. Heyn aan Victor Sprinckel, Siam, 17 Mt. 1610; Copiebrief van Lambert Jacobsz. Heyn aan Victor Sprinckel, Siam, 15 April 1610; Victor Sprinckel aan Lambert Jacobsz. Heyn in Ajudhja, Patani, 16 Mei 1610; Copiebrief van Lambert Jacobsz. Heyn aan Victor Sprinckel, Siam, 20 Mei 1610; Victor. Sprinckel aan Lambert Jacobsz. Heyn in Ajudhja, Patani, 6 Juni 1610; dezelfde aan denzelfde, Patani, 1 Aug. 1610; dezelfde aan denzelfde, Patani, 20 Aug. 1610; Res. XVII, 11 Sept. 1610; Copiebrief van Lambert Jacobsz. Heyn aan Victor Sprinckel, Siam, 20 Sept. 1610; dezelfde aan denzelfde, Siam, 5 Oct. 1610; dezelfde aan denzelfde, Siam, 20 Oct. 1610; Jean van der Heesen aan Lambert Jacobsz. Heyn c.s. in Ajudhja, Patani, 26 Oct. 1610; Copiebrief van Victor Sprinckel aan beww. kamer Delft, Patani, 31 Oct. 1610; Copiebrief van Corn. Francx aan Victor Sprinckel, Ajudhja, Oct. 1610; Copiebrief van Peter Segers aan 't kantoor te Bantam, Patani, 2 Nov. 1610; Copie-ress. van Both en zijn raad, 20 Dec. 1610-13 Juli 1611; Inventaris van de negotieboeken, per Leiden naar patria gezonden.

1) Pag. 30. Vgl. ook p. 35. 
over hem was geweest, hem een scherpe berisping deed toekomen: het was beter geweest, schrijft hij, dat ge met Albert Rutgers naar Bantam waart gegaan „ende van een huijs te tijmmeren achter ghelaeten, als oock mede van alle daghe droncken te drijncken". Ook Janssen's chef Victor Sprinckel uit zijn verontwaardiging over wat op Borneo gebeurde in een schrijven aan Jacques l'Hermite te Bantam. „'t Is al verlooren, $S^{r}$ l'Hermite”, zoo lezen we hierin, ,jonghelyeden in dese contreyen met cargasoenen erghens te senden, want sij laten haerlieder vorstaen, soo sij oock wel dorven seggen : Ick ben alsoo groot meester als die mij uutghesonden heeft, ten anderen oock en hebben noyt niet veel handelinghe van ghelde ghehadt, soo dat sy haer laten perswaderen, al boter totten boome is, ende van den hende ${ }^{1}$ ) af teeren, niet overdinckende eens rekeninghe te moeten doene" ${ }^{2}$ ).

Hoe op Borneo het tastenderwijs begonnen werk voortging, en hoe in 1609 een verdrag tot stand kwam met het op Soekadana naijverige Sambas, dat behoort eigenlijk niet meer tot mijn onderwerp ${ }^{3}$ ); Patani namelijk verliest zijn invloed op den Borneoschen handel, de leiding daarvan gaat op Bantam over. Bovendien zijn deze gebeurtenissen elders reeds beschreven ${ }^{4}$ ).

Ik mag deze afdeeling over het bewind van Victor Sprinckel niet beëindigen alvorens nog te hebben vermeld, dat in 1611, het jaar

1) $=$ ende.

2) Het moet opgemerkt worden, dat deze uiting van Sprinckel door Heeres, Hendrik Janssen, p. 105, ten onrechte op. Hendrik Janssen betrokken wordt.

3) Vgl. over Sambas nog hoofdstuk VI.

4) $\mathrm{Bij}$ Van Dijk: Borneo, p. 131 v. Vgl. verder over 't bovenstaande: De Jonge III, p. 88 v. en bijl. XXVIII (de rol van Sprinckel in de betrekkingen met Borneo wordt hier eenigszins overdreven voorgesteld. Verder geeft De Jonge, gelijk reeds Heeres : Hendrik Janssen, p. 107, noot 1, opmerkte, Janssen te veel eer door hem als stichter van den handel met Soekadana voor te stellen); Tiele Eur. 4 VIII, p. 76; Heeres: Hendrik Janssen, p. 107; Heeres: Corp. Dipl. I, p. 73 v.; Copiebrief van Hendrik Janssen aan Jan Willemss. Verschoor te Bantam, Patani 29 Oct. 1607 (Copieb. H. J.); idem aan Steven Doenss. te Grissee, Patani, 29 Oct. 1607 (Copieb. H. J.); idem aan Cornelis Francx in Johor, Patani, 29 Oct. 1607 (Copieb. H. J.); idem aan Heindrick van Bergel, Patani, 29 Oct. 1607 (Copieb. H. J.); idem aan Frederik de Houtman, gouverneur op Ambon, Patani, 29 Oct. 1607 (Copieb. H. J.); idem aan adm. Cornelis Matelief te Bantam, Patani, 6 Dec. 1607 (Copieb. H. J.); idem aan Jacques 1'Hermite te Bantam, Patani, 6 Dec. 1607 (Copieb. H. J.); Albert Rutgers aan Hendrik Janssen te Patani, Bantam, 18 April 1608; Hendrik Janssen aan Jacques 1'Hermite te Bantam, Patani, 24 April 1608; Copiebrief van Victor Sprinckel aan Jacques l'Hermite de Jonge te Bantam, Patani, 25 Sept. 1608 (Copieb. V. S.); Copiebrief van Hendrik Janssen aan Pieter Aertss. in Soekadana, Patani, 30 Oct. 1608 (Copieb. H. J.). 
dus, waarin Hendrik Janssen voor de tweede maal het bestuur over onze vestiging in Patani in handen kreeg, op 26 Februari aldaar groote schade werd geleden, doordat een plotselinge brand de loge verwoestte, en een hoeveelheid goederen ter waarde van meer dan 4000 realen van achten verloren deed gaan ${ }^{1}$ ).

c. De tweede bewindsperiode van Hendrik Janssen (1611-1613).

In 1611 kreeg, zooals we gezien hebben, Hendrik Janssen, die na den dood van Ferdinand Michiels tijdelijk Patani bestuurd had, als officieel bestuurder de leiding over de Nederlandsche factorij aldaar. Zijn onderkoopman Matthijs de Mere stond hem in de volgende jaren krachtig ter zijde, „een cloeck ende getrouw jongman”, zooals zijn chef hem noemt. En dezen krachtigen steun kon de opperkoopman goed gebruiken, want de tijden werden moeilijk. Dit kwam ten deele hiervan, dat de inlanders zich aldoor ten koste van de Nederlanders trachtten te verrijken: het vele geld, dat aan tollen en geschenken besteed moest worden, woog zwaar voor den handel; veel steun kon men in dit opzicht niet krijgen van de koningin, al was die den onzen blijkbaar bij voortduring goed gezind: de grooten des lands stoorden zich maar weinig aan haar en speelden den baas. Verder deed het ons prestige, evenals ook reeds vroeger, afbreuk, dat Patani zoo schaars door schepen bezocht werd, wat weer nijpend geldgebrek tengevolge had. De financieele steun, door de Brak in 1611 gebracht ${ }^{2}$ ), was onvoldoende geweest, en in de eerste maanden van 1612 zag men tevergeefs naar schepen uit. Noch uit Bantam, noch uit de Molukken kwam hulp opdagen. Hieruit is te zien, zoo klaagt men in het onder Patani ressorteerende kantoor in Siam, ,hoe weynich die van Bantam de andere comptoiren ter herten gaet". Toch wat dit verwijt niet geheel gerechtvaardigd: daar in 't Oosten de strijd om de Molukken met kracht werd voortgezet, werden daarop de beschikbare krachten geconcentreerd en kon er voor Patani weinig gedaan worden. Zoo zagen ook de bewindhebbers het in: uit hun naam werd in December 1611 een brief geschreven aan Peter Segers, in Patani ${ }^{3}$ ), waarin ze er den nadruk op legden, dat

1) Zie: Mateo Coteels aan Hendrik Janssen te Patani, Bantam, 20 Maart 1612; Peter Segers aan bewindhh. kamer Amst., Bantam, 5 Dec. 1612.

2) Zie p. 56.

3) Een brief, die, blijkens 't voorgaande, Segers niet meer in Patani zou bereiken, en wel aan Janssen ter hand gesteld zal zijn. 
allereerst het veilig stellen van den Compagnie's invloed in de Molukken en op de Banda-eilanden aan de orde was, en eerst daarna de Chineesche handel aan de beurt kwam. - Dat op zich zelf deze laatste van belang werd geacht, blijkt uit de bijvoeging, dat Segers den gouverneur-generaal Both bij voortduring op de hoogte moet houden over alles, wat hij kan te weten komen van de Chineezen, „die meest haer frequentatie in Patana houden”. -

Geldgebrek was dus troef in 't kantoor van Patani, en, daar men toch den handel met de Chineezen niet wilde opgeven, werd wederom bij herhaling geld van de koningin geleend. Deze gewoonte lokte van verschillende kanten critiek uit. Segers, in 1612 in Bantam zijnde, vindt, dat dit leenen slecht is voor onzen naam. Coen, in 1613 in Indië aangekomen, vindt eveneens, dat, al mag Hendrik Janssen ook door de omstandigheden tot deze leen-transacties gedwongen zijn, deze nogtans strekken ,tot groote disreputatie ende nadeele der Comp '”. Ook Coen's voorganger als boekhouder-generaal in Bantam, Mateo Coteels, had reeds zijn bezwaren geuit. De geldleeningen op interest zijn volgens zijn opinie ,innatiën" ${ }^{1}$ ), die men schuwen moet als de pest. Hij zinspeelt er op, hoe men in vroegeren tijd van de koningin contanten verkregen had door middel van een geschenk. Janssen blijft hierop het antwoord aan Bantam niet schuldig. Op 12 October 1613 zendt hij aan den opperkoopman Jacop die Schot in Bantam het antwoord op de terechtwijzing van Coteels, die dan reeds overleden is. Als 't om een som van 4 à 5000 realen ging, zou men „met een erkentenisse offte schenkasije” zijn doel wel kunnen bereiken, maar dit ging niet bij bedragen van 15 tot 20000 realen, zooals nu jaar op jaar noodig waren; daarvoor werd beter rente betaald. Men kon dan ook terstond geholpen worden, terwijl men met 't schenkagessysteem ,3 weecken offte een maent het naer lopen met gevouwen handen als bedelaers van de eene menterins dore tot die ander moet hebben" ${ }^{2}{ }^{3}$ ).

1) $\mathrm{Hij}$ bedoelt waarschijnlijk innovatiën.

2) $\mathrm{Bij}$ Heeres: Hendrik Janssen, p. 115, wordt het ten onrechte zoo voorgesteld, dat ook bij 't betalen van rente dergelijke vernederende demarches noodig waren.

3) Zie over 't voorgaande: Tiele Eur. 5 I, p. 267; Heeres: Hendrik Janssen, p. 113 v.; Groeneveldt, p. 48 v.; Copiebrief uit naam der beww. aan Peter Segers in Patani, Amst. 17 Dec. 1611; Cornelis van Nieuwenroode en Marten Houtman an Hendrik Janssen te Patani, Ajudhja, 3 Mei 1612; Hendrick van Boecholt aan Hendrik Janssen te Patani, (Batasour?), 2 Juni 1612; Copiebrief van Jacques Specx aan Cornelis van Nieuwenroode en Marten Houtman te Ajudhja, Firando, 3 Nov. 1612; Peter Segers aan beww. kamer Amst., Bantam, 
Gelukkig, dat Hendrik Janssen in t midden van 't jaar 1612 eenigszins uit zijn isolement verlost werd, en in een betere financieele positie kwam door 't bezoek van schepen uit Bantam. 20 Maart van dat jaar vertrok eerst ' $t$ jacht de Hazewind, schipper Evert Janssen, vandaar. Met eenige andere jachten moest het eerst Borneo aandoen, en daarna de kas der kantoren van Johor en Patani versterken met respectievelijk 10000 en 50000 realen $^{1}$ ) van achten. Bovendien kreeg het jacht nog een lading aan goederen mee, waaronder 600 olifantstanden en eenige kleedjes. Na het bezoek aan Patani moest de Hazewind doorgaan naar Japan. De reis duurde langer dan oorspronkelijk geraamd was, waarschijnlijk ook al door het oponthoud aan de kust van Borneo, waar we weten, dat 't jacht zich op 1 Juni bevond ${ }^{2}$ ). Over 't bezoek daarna aan Johor is mij weinig met zekerheid bekend. 17 Juni lag de Hazewind daar in ieder geval voor anker. 3 Juli kwam 't jacht voor Patani aan, en 't is daar tot den $13^{\text {en }}$ van dezelfde maand gebleven. Daarop vertrok het volgens instructie naar Japan.

$\mathrm{Bij}$ haar aankomst te Patani had de Hazewind daar nog een ander schip aangetroffen, namelijk de Bantam, welke eerst later uit de gelijknamige stad was weggezonden. Dit schip, oorspronkelijk naar de Molukken bestemd, had door den ongunstigen moesson zijn vaart moeten opgeven, en, daar men het niet nutteloos wilde laten liggen, werd het naar Johor en Patani gezonden om alles, wat daar gereed zou zijn, peper zoowel als Chineesche waren, naar Bantam te brengen. Zoo mogelijk moest Hendrik Janssen als verdere lading voor 't schip nog een goede partij speauter ${ }^{3}$ ), aluin en witte suiker koopen, artikelen, die dienstig konden zijn voor de Koromandelkust, welke jaarlijks meer van belang werd voor de Compagnie. Mocht de kapitaalsversterking per Hazewind, die, naar men immers aannam, reeds vroeger in Patani gekomen zou zijn, niet voldoende zijn geweest, dan mocht Hendrik Janssen nog van 10 tot 15000 realen uit het schip lichten.

5 Dec. 1612; Mateo Coteels aan Hendrik Janssen te Patani, 20 Mt. 1613; Hendrik Janssen aan Jacop die Schot te Bantam, Patani, 12 Oct. 1613; J. P. Coen aan beww. te Amst., Bantam, 1 Jan. 1614 (Col. Coen I, p. 1 v.); Copiebrief van Hendrik Janssen aan J. P. Coen, Patani, 25 Oct. 1616.

1) Het dient opgemerkt, den Hendrik van Boecholt uit Batoesawer - hier bevond zich onze factorij in Johor, op 2 Juni 1612 aan Hendrik Janssen schrijft, dat de Hazewind, die dan nog niet in Johor is aangekomen, voor Patani 40000 realen van achten heeft.

2) Voor Soekadana.

3) Vgl. Verwijs en Verdam: Middelnederlandsch woordenboek, s.v. Speauter : een mengsel van lood, of ook messing, en tin; tin; misschien ook zink.

Verh. dl. I. 
Ongeveer 17 April moet de Bantam onder kapitein Willem Nobelet vertrokken zijn. 19 Mei kwam het schip in Johor aan, vanwaar het ongeveer 2 Juni vertrok, om den $16^{\text {en }}$ daaraanvolgende Patani te bereiken. De kooplieden aldaar waren eenigszins ontstemd over de geringe hoeveelheid goederen, die ermee aangebracht werden. De lastgeving omtrent het laden hebben ze blijkbaar met jjver vervuld: een schoon cargasoen ter waarde van \pm 90000 realen van achten, naar 't schijnt vooral bestaancle uit Chineesche zijde, werd ingescheept, waarop de Bantam \pm 15 October, na een langdurig bezoek dus, van Patani wederom de terugreis aanvaardde. De Bantam moet vergezeld geweest zijn van een jacht, de Enkhuizen genaamd, dat in de bocht van Patani gebouwd was $\left.{ }^{1}\right)^{2}$ ).

In 1612 werd het kantoor dus wel meer in den Compagnieshandel en in het scheepvaartverkeer betrokken dan in 't voorafgaande jaar. Ook in andere opzichten krijgen we den indruk van grootere levendigheid en actie. Zoo werd er door Hendrik Janssen een nieuwe loge gebouwd. Dit was stellig geen overbodige weelde; de Heeren XVII toch waren overtuigd, dat het oude huis ,,van cleender importantie" was. In Bantam, waar men 't belang van een nieuwe loge inzag, werd besloten, dat het jacht de Hazewind ${ }^{3}$ ) te Johor 200 planken moest inladen, die dan in Patani bij het bouwen van de loge konden worden gebruikt. Het werk werd aldaar met spoed aangevat: 15 October, zoo weten we uit een schrijven van Hendrik Janssen,

1) „A small pinnas, built heere, called Enchusen” (Moreland: Peter Floris, p. 43 ; en op p. 82 : „Little Enchuis of Bantam, sette upp heere by the shipp Bantam).

2) Vgl. over 't bezoek van de Hazewind en de Bantam: Van Dijk: Borneo, p. 146 v.; Moreland: Peter Floris, p. 33, 35 v., 43; Copiebrief van G.-G. (aan?), Bantam, 26 Febr. 1612; Mateo Coteels aan Hendrik Janssen te Patani, Bantam, 20 Mt. 1612; Victor Sprinckel aan Hendrik Janssen te Patani, Bantam, 20 Mt. 1612; Mateo Coteels aan Hendrik Janssen te Patani, Bantam, 25 Mt. 1612; idem aan denzelfde, Bantam, 17 April 1612; Everard Deynsen aan Hendrik Janssen in Patani, Soekadana, 1 Juni 1612; Hendirck van Bocholt aan Hendrik Janssen te Patani, (Batasour?), 2 Juni 1612; Hendrick van Boecholt aan Hendrik Janssen te Patani, Batasouwer, 17 Juni 1612; Mateo Coteels aan Hendrik Janssen in Patani, Bantam, 27 Juni 1612; Extractbrief van Hendrik Janssen (aan?), Patani, 15 Oct. 1612; Copiebrief aan G.-G. (van?), Bantam, 16 Oct. 1612; Extractbrief van Mattheo Cotteels (aan?), Bantam, 17 Dec. 1612; Copietranslaat van des konings brief „ofte” contract van Ligor, Ajudhja, 1612; Copiebrief van Marten Houtman aan Hendrik Janssen te Patani, Ajudhja, 18 Mt. 1613; Mateo Coteels aan Hendrik Janssen te Patani, 20 Mt. 1613; Hendrik Janssen aan beww. te Amst., Bantam, 28 Dec. 1613; de extractbrief van Van den Broecke, bedoeld op p. 23 noot 2.

3) Zie p. 65 . 
was de loge in ieder geval reeds gereed; zij was er in 't bijzonder op berekend, dat de er in te bergen goederen voor brand gevrijwaard zouden zijn ${ }^{1}$ ).

Had Hendrik Janssen zijn zin gekregen, dan zou een plan tot uitvoering gekomen zijn, dat nog vrij wat grootscher was dan het bouwen van een nieuwe loge. Hij wilde den handel in Patani en in verren omtrek stabiliseeren en beveiligen door het stichten van een fort. In December 1611 had hij aan bewindhebbers zijn gedachten meegedeeld: op Poeloe Condor, een eiland, dicht bij de kust van Cochinchina gelegen ${ }^{2}$ ), zou het fort moeten verrijzen, en wel hoof(lzakelijk ter verzekering van den Chineeschen handel. Zelf hadden de Chineezen, ,geschat" als ze in Patani werden met tollen en andere lasten, er op aangedrongen; zouden ze onverhoopt niet met hun jonken naar Poeloe Condor gaan, dan kon men hen door middel van een tweetal jachten, die tot dat doel onder het te maken fort moesten gereed liggen, ertoe dwingen. Dit fort zou een machtspunt worden, dat ook de heele Noordkust van Java in bedwang zou kunnen houden (er bestond nog geen kasteel van Batavia!); verder zou het den handel op Cambodja kunnen controleeren, een handel, welke, we zagen het reeds ${ }^{3}$ ), van groot belang was voor onze betrekkingen met Japan.

Dit plan is niet tot uitvoering gekomen; wel echter kwam een verbreeding der handelsbasis in deze streken tot stand door de vestiging van een nieuw kantoor, namelijk in Sangora, een kustplaats, die ongeveer veertien mijlen van Patani verwijderd was $\left.{ }^{4}\right)$. Jarenlang hadden de Chineezen ook daar reeds op aangedrongen; ze hoopten daar hun handel met de Nederlanders zonder inconveniënten te kunnen drijven. En ook de koning, die over Sangora het oppergezag uitoefende, had reeds voor jaren van zijn goede gezindheid doen blijken. Reeds aan Van der Leck had hij den vrijen handel en het stichten van een loge aangeboden. Ik sprak van oppergezag: de koning van Ligor, hier bedoeld, oefende namelijk de suzereiniteit uit over Sangora, toentertijd, ,een vlecxken van weijnich inwoonders”, naar we vernemen; zijn zoon was koning van Bordelon ${ }^{5}$ ); deze oefende ook het rechtstreeksche gezag uit over Sangora. Hendrik

1) Vgl. p. 63 .

2) Zie p. 23.

3) Zie p. 50 v.

4) Zie p. 2.

5) Tusschen Ligor en Sangora gelegen (zie ook p. 39 noot 1). Alle drie plaatsen stonden onder de opperhoogheid van Siam. 
Janssen besloot nu, in overleg met Willem Nobelet, kapitein van het schip Bantam, van de gunstige gelegenheid gebruik te maken. $\mathrm{Hij}$ zond 13 Augustus 1612 een schrijven aan den koning van Ligor, die zich toen als vazal van den koning van Siam in Ajudhja bevond. $\mathrm{Hij}$ verklaarde, onder hoogere goedkeuring van den gouverneurgeneraal, per eerste gelegenheid volk naar Sangora te zullen zenden, om daar een factorij te stichten, onder conditie, dat de koning van Ligor en diens troonopvolger, de koning van Bordelon, onze rechten in Sangora schriftelijk zouden stipuleeren. Op 2 September daaraanvolgende konden Van Nieuwenroode en Houtman uit Ajudhja aan Hendrik Janssen melden, dat van den koning van Ligor een contract was verkregen, waarin den onzen werd toegestaan, ,vrie tollen ende rechten, gheen ander natien als wij moghen handelen, een huijs van steen ende muier, ende alles te moghen maecken soo ' $t$ den $E$. $H^{r}$ Genne' goet dunckt". Spoedig daarna vertrok Van Niewenroode met dit contract naar Patani. De koning van Ligor zond tevens een brief aan zijn zoon, welke de rechten der Hollanders van zijn kant bevestigde, en in November 1612 ook nog een aan den gouverneurgeneraal van de „Beneden winden”, waarin hij zijn beloften herhaalde, o.a. dat Engelschen, Franschen, Portugeezen noch eenige andere "boven lants wints" natie naast ons in Sangora zou mogen handelen, terwijl hij verzekerde, dat de Chineezen en andere inlandsche kooplieden een welwillende behandeling zouden ondergaan en slechts een redelijken tol zouden behoeven te betalen. Uit een later schrijven van Jan Pietersz. Coen ${ }^{1}$ ) weten we, dat de koning verwachtte, voor zijn welwillendheid jaarlijks met eenige Hollandsche goederen te worden vereerd. Ook de beide gouverneurs van Sangora, de orangkaja Siriaragoena ${ }^{2}$ ) en Dato $\mathrm{Mugul}^{3}$ ), verklaarden schriftelijk aan Hendrik Janssen, dat zij den vrijen handel voor de Hollanders, ook in toekomende tijden, zouden respecteeren. De gouverneurgeneraal Pieter Both ten slotte approbeerde de vestiging der onzen in deze nieuwe nederzetting.

De uitvoering van het vestigingsplan geschiedde op bescheiden schaal: het betrof immers alleen een hulpkantoor van Patani. Van Nieuwenroode en Jan Roekoe ${ }^{4}$ ) vertrokken naar Sangora om den handel te vestigen. Drie leggers uit Patani zouden er ,,in een Maleijs

1) Van 1 Jan. 1614 aan beww. v. Amst.

2) Elders Sirrigoena.

3) Elders Dato Mogul en Dato Mogol.

4) Zie p. 37. 
huisken" wonen om er de Compagniesbelangen te behartigen. Hieronder behoorde ook Roekoe ${ }^{1}$ ). Daarna, in den loop van het jaar 1613, liet Hendrik Janssen, ,een cleijn huysken” in Sangora maken, „,van cleynnen prijs". Maar hoe bescheiden de stichting ook was, nieuwe mogelijkheden waren geschapen, en de overmoed der inlandsche grooten van Patani kreeg een heilzame rem.

In het begin schijnt nog even het gevaar te hebben bestaan, dat in Sangora ondanks de vastgestelde bepalingen toch Europeesche concurrenten zouden worden toegelaten, namelijk de Engelschen. De gouverneur Dato Mugul schijnt bij hen althans verwachtingen van dien aard te hebben opgewekt, in de meening, dat hij hiermee overeenkomstig de inzichten van den koning van Ligor handelde. Toen deze echter via onze factorijhouders in Patani en Ajudhja hierover gehoord had, schreef hij een brief aan Dato Mugul, waarin dezen op 't hart gedrukt werd, dat de bepalingen van 't contract ten volle nagekomen moesten worden. Aan de Engelschen werd dan ook de handel in Sangora niet toegestaan. In de eerste tijden heeft de nieuwe vestiging goede winsten afgeworpen en kon Hendrik Janssen trotsch zijn op het door hem bereikte succes.

En hoe hebben nu zijn superieuren over de stichting gedacht? Coteels, boekhouder-generaal in Bantam, weifelt. Hij vindt Sangora voor de Chineezen wat afgelegen. De toekomst zal nog moeten uitmaken, welke van de twee plaatsen het geschiktst voor dezen handel zal blijken. Coen, later in zijn plaats in Bantam, prijst de stichting der nieuwe factorij. De bewindhebbers zijn sceptisch gestemd: de vestiging in Patani zal er schade van ondervinden. Maar Hendrik Janssen verdedigt zijn beleid tegenover hen in 1616, als de zaken in Sangora er iets minder gunstig voor staan dan in 't begin. Zijn handelwijze, zoo zegt hij, is volkomen in overeenstemming geweest met vroegere instructies uit patria, waarbij het sluiten van contracten tot profijt van de negotie werd aanbevolen. Dat later in Sangora een inzinking zou ontstaan, was bij de stichting ook niet te voorzien geweest; verder behoefde die inzinking ook niet definitief te zijn; men moest geduld hebben. En in Patani, zoo vervolgt hij, was het voordeel alvast zeer reëel: men kon nu, met het stille dreigement, Sangora steeds meer als handelsplaats te begunstigen, van de koningin en de mandarijnen concessies verkrijgen, waar vroeger zelfs door middel van schenkages niet aan te denken was geweest.

1) Ik krijg, anders dan Tiele Eur. 5 II, p. 241, den indruk, dat Van Nieuwenroode er niet als factorijhouder gebleven is. 
Inderdaad, de ontsteltenis over onze vestiging in Sangora was bij de machthebbers in Patani groot geweest. En zoo toegevend ze werden tegenover de Hollanders, om toch in vredesnaam den voordeeligen handel van dezen maar in hun stad te houden, zoo groot was hun woede tegen den koning van Ligor. Ze legden zich er nu op toe, alle jonken, die bestemming hadden naar Ligor en Sangora, aan te halen, om aldus de nieuwe concurrentie den kop in te drukken. Voor den koning van Ligor, waarover toch reeds, naar Houtman in Maart 1613 aan Hendrik Janssen schreef, in Ajudhja heimelijk gezegd werd, dat hij naar 't bezit van Patani streefde, was deze handelwijze der Pataniërs eigenlijk koren op den molen. En de koning van Siam, zijn leenheer, schijnt op zijn hand geweest te zijn, mede omdat de Patanische gezanten, die hem de gewone leenhulde moesten brengen, langer uitbleven dan hem gepast leek. Zoo gespannen werd de toestand, dat een plotselinge overval op Patani te duchten stond. Geen wonder, dat Coen van oordeel was, dat van de onzen in deze netelige kwestie meer dan gewone tact vereischt werd. Gelukkig bleef tenslotte alles rustig ${ }^{1}$ ).

In verband met Sangora sprak ik over de Engelschen. Ook ten

1) Vgl. over het voorgaande: Tiele Eur. 5 II, p. 241; Heeres: Hendrik Janssen, p. 113 v.; Res. der XVII, 10 en 14 Nov. 1611; Extract-brief van Hendrik Janssen (aan?), Patani, 4 Dec. 1611; Victor Sprinckel aan Hendrik Janssen te Patani, Bantam (er staat foutief Patany boven), $20 \mathrm{Mt}$. 1612; Copiebrief van Hendrik Janssen c.s. aan den koning van Ligor, Bordelon en Sangora, Patani, 13 Aug. 1612; Cornelis van Nieuwenroode en Marten Houtman aan Hendrik Janssen, Ajudhja, 2 Sept. 1612; Marten Houtman aan Hendrik Janssen te Patani, Ajudhja, 20 Sept. 1612; Extract-brief van Hendrik Janssen (aan?), Patani, 15 Oct. 1612; Marten Houtman aan Hendrik Janssen te Patani, Ajudhja, 26 Dec. 1612; Translaat uit den brief van orangkaja „Siriaragoena ende Dato mugul", gouverneurs van Sangora, 1612; Copie-translaat uit des konings brief „ofte" contract van Ligor, Ajudhja, 1612; Copiebrief van Marten Houtman aan Hendrik Janssen, opperkoopman te Patani, Ajudhja, 18 Mt. 1613; Mateo Coteels aan Hendrik Janssen te Patani, 20 Mt. 1613; Copiebrief van Marten Houtman aan Hendrik Janssen te Patani, Ajudhja, 31 Mt. 1613; idem aan denzelfde, Ajudhja, 24 April 1613; Hendrik Janssen aan Jacop die Schot te Bantam, Patani, 12 Oct. 1613; Abraham van den Broecke aan beww., Patani, 12 Oct. 1613; Hendrik Janssen aan beww. te Amst., Bantam, 28 Dec. 1613 ; J. P. Coen aan beww. te Amst., Bantam, 1 Jan. 1614 (Col. Coen I, p. 1 v.); Copiebrief van de XVII aan J. P. Coen, Amsterdam 21 Nov. 1614 (Col. Coen IV, p. 287 v.); Hendrik Janssen aan beww. te Amst., Patani, 25 Oct. 1616; Copiebrief van Hendrik Janssen aan J. P. Coen, Patani, 25 Oct. 1616; Jan van Hasel aan J. P. Coen te Jacatra, Sangora, 4 Oct. 1620; J. P. Coen c.s. aan beww., Jacatra, 8 Jan. 1621 (Col. Coen I, p. 606 v.); de extractbrief van Van den Brocke, bedoeld op p. 23, noot 2. 
opzichte van hen was 1612 een merkwaardig jaar. Toen toch kregen de Hollanders in ,de bocht" van Patani voor 't eerst met hen te doen. Het Engelsche schip de Globe, in Januari 1611 onder Anthony Hippon uitgevaren, verscheen, na een bezoek aan de Koromandelkust en Bantam, op 2 Juli 1612 voor Patani met een lading kleedjes. Op dit schip bevonden zich ook twee Nederlandsche kooplieden, Pieter Willemsz. Floris ${ }^{1}$ ) en Lucas Antheunissen. Al was dit bezoek Hendrik Janssen ook in hooge mate onwelkom, hij moest de nieuwaangekomenen, als behoorende tot een bevriende natie, toch als gelijken erkennen, en aanzien, dat ze in Patani een factorij stichten. De Globe voer een paar maal van Patani naar Siam, waar eveneens een Engelsche nederzetting tot stand kwam. Daarna vertrok het schip op 11 November 1613 van Patani naar de Koromandelkust.

Ook te Patani en in Siam zou zich dus een deel van den soms verholen, soms openlijken strijd afspelen, die in Bantam en in de Molukken naturen als Coen met grimmigen haat zou vervullen, en die zijn voorloopig einde vond in het drama op Ambon in 1623. Op de bijzonderheden van dezen strijd in verband met ons onderwerp hoop ik nader terug te komen ${ }^{2}$ ).

In 1613, het laatste jaar van zijn bewindsperiode, werd Hendrik Janssen opgeschrikt door een gebeurtenis in een der naburige factorijen, die wederom bewees, hoe precair het bestaan onzer vestigingen op 't schiereiland van Malakka was. Het kantoor van Johor, dat veelal door dezelfde Compagniesschepen werd bezocht als Patani en met dit laatste goede betrekkingen onderhield, werd op 6 Juni 1613 door de Atjehers overweldigd. Het deelde hierbij het lot van de geheele stad, welke, zoo schrijft Hendrik Janssen, ,ganschelicken verwoest ende verdestrueert" werd. De Hollanders hadden zich bij de veete tusschen de beide Oostersche staatjes niet neutraal gehouden, zooals de Atjehers geëischt hadden, maar hulp aan de Johorieten verleend; ook uit het schip de Hoop ${ }^{3}$ ), dat de dier tijde toevallig op de reede lag, werd een aantal mannen afgezonden om deze hulp effectiever te maken. Deze laatsten werden met de factorijhouders gevangengenomen en naar Atjeh weggevoerd. Gelukkig, dat de vrede tusschen Johor en Atjeh spoedig werd hersteld, en daarop

1) Zie p. 2, noot 3. De bijvoeging ,van Elbing”, die we aantreffen, wijst op Poolsche herkomst, maar hij was in dienst van onze O. I. C. geweest. Zie verder over deze episode hoofdstuk VII.

2) Vg1. uitvoeriger over 't bovenstaande: hoofdstuk VII.

3) Zie beneden. 
ook de gevangene Hollanders wederom in vrijheid werden gesteld ${ }^{\mathbf{1}}$ ).

Toen Johor door de Atjehers werd verwoest, spoedde de „,verbonden" tijd van Hendrik Janssen reeds weder ten einde. Hij verlangde naar het vaderland terug, en moest dus als hoofd van de factorij te Patani vervangen worden. Men had dezen keer geen moeite met het zoeken van een opvolger. Abraham van den Broecke bood zich namelijk als zoodanig aan. Deze Compagniesdienaar, dien we reeds in gezelschap van Matelief ${ }^{2}$ ) en als medevestiger van onzen handel in Japan ${ }^{3}$ ) aantroffen, had overigens een allesbehalve gunstige reputatie en zou, na het goede bewind van Hendrik Janssen, in Patani een hoogst bedenkelijke kracht blijken. Niet alleen was hij een genotzuchtig en een hebzuchtig man; voor een veel ernstiger feit had hij terechtgestaan: in Februari 1612 was hij in Bantam wegens beganen manslag tegen Hendrik Janssen, kwartiermeester op 't jacht de Hazewind ${ }^{4}$ ), ter dood veroordeeld. Nog in dezelfde maand evenwel had de raad van Bantam, onder leiding van Coteels, hem het leven geschonken ${ }^{5}$ ), en nu ontzag Van den Broecke zich niet, te streven naar een bediening, die hem krachtens zijn antecedenten allerminst toekwam. In Mei 1613 op Ambon bij den gouverneur-generaal Both zijnde, had hij de vrijmoedigheid, dezen mede te deelen, dat Hendrik Janssen uit Patani in ieder geval op den hem toekomenden tijd verlost wilde worden, ,als wel lange uijt het vaderlandt geweest hebbende", zichzelf aanbiedende, diens plaats als opperkoopman te vervullen. Both was waarschijnlijk niet overmatig van bruikbare opperkooplieden voorzien; hij had gehoord, dat Van den Broecke wel bekwaamheden bezat, en vreesde, dat, als hij diens aanbieding afsloeg, het zou kunnen gebeuren, dat Van den Broecke zijn diensten aan de Engelschen aanbood. Een voordeel kon het genoemd worden, dat hij althans Patani kende, daar hij er ook in 1612 met 't schip Bantam geweest was. Kortom: het verzoek werd ingewilligd, en zoo vertrok Janssen's

1) Vgl. over de verovering van Johor: Netscher: De Nedd. in Djohor en Siak, p. 30 ; Moreland, p. 81 (het bericht hierin over het dooden van eenige Hollanders bij 't nemen van Johor door de Atjehers vond ik niet bevestigd); Hendrik Janssen aan Jacop die Schot te Bantam, Patani, 12 Oct. 1613; Abraham van den Broecke aan beww., Patani, 12 Oct. 1613; Hendrik Janssen aan beww. te Amsterdam, Bantam, 28 Dec. 1613; J. P. Coen aan beww. te Amst., Bantam, 1 Jan. 1614 (Col. Coen I, p. 1 v.); Pieter Both aan beww., Bantam, 1 Jan. 1614.

2) Zie p. 37 .

3) Zie p. 50.

4) Niet den ons bekenden Hendrik Janssen dus.

5) In een stuk van 25 Juli 1612 werd dit geconfirmeerd door Pieter Both. 
opvolger over Boeton, waar hij zich nog wist te verrijken, naar Bantam, en vandaar naar Patani. Op 't jacht Enkhuizen ${ }^{1}$ ) kwam hij hier 26 Juli aan. Wel was het, naar we weten, de bedoeling geweest, onderweg ook Johor aan te doen, maar hiervan was afgezien, toen de opvarenden bericht kregen, dat de Atjehers voor de stad lagen; het jacht was niet weerbaar genoeg om een conflict te risqueeren. Hendrik Janssen is niet met hetzelfde jacht, waarmee zijn opvolger aankwam, naar Bantam vertrokken, naar het schijnt alweer opdat deze een tijdlang althans van zijn ervaring en voorlichting zou kunnen profiteeren. Waarschijnlijk kort na 12 October 1613 is het jacht Enkhuizen naar Bantam teruggekeerd, terwijl het van de gereedliggende lading zooveel mogelijk meenam, namelijk 31 kisten met ruwe zijde en eenige zijdewaren.

Bij zijn aankomst in Patani had Van den Broecke hoop gehad, aldaar het schip de Hoop ${ }^{2}$ ) aan te treffen. Reeds omstreeks 20 Maart 1613 was dit van Bantam of Jacatra vertrokken onder den opperkoopman Abraham Theunemans en den schipper IJsbrant Jacobss. de Hoijer ${ }^{3}$ ). Het bracht 70000 realen mee voor Patani, afgezien van een lading kleeden. Onderweg zouden bovendien in Johor 10000 realen moeten worden gelaten. $\mathrm{Na}$ de in Patani beschikbare zijde te hebben ingeladen, moest de Hoop koers zetten naar de Molukken. In Patani, waar ook Hendrik Janssen het schip reeds verwacht had, lag een behoorlijk cargasoen voor inlading gereed; aan de 70000 realen bestond groote behoefte. „Waere dit schip”, zoo schrijft Coen later, ,tot Patane gecomen ${ }^{4}$ ), 't soude de Comp' veel duijsenden waert geweest zijn"; nu had Hendrik Janssen wederom 13000 realen van de koningin moeten leenen tegen hooge rente ${ }^{5}$ ). Wij moeten voor het goed begrip van de vertraagde aankomst van de Hoop dit schip even op zijn wonderlijken zwerftocht volgen.

1) Zie p. 66.

2) Zie p. 71 .

3) Aldus Both in een schrijven aan bewindhebbers van 1 Jan. 1614. Coen noemt hem in een brief van denzelfden datum, aan bewindhebbers te Amsterdam, Isbrandt Jacobssen Goijer.

4) Tijdig dus.

5) „The Hollanders tooke upp $13,000 \mathrm{R} 8$ with condition if they repaye the same within a month att 5 per cento, if in 3 months att 6 per cento, and within a yeare att 10 per cento, besides 1 per cento to the treasurer and the gifte" (Moreland, p. 75 v.). Een ander gegeven over den rentevoet van een dergelijke leening uit ongeveer dien tijd in een schrijven van den Engelschman John Gourney in Patani, d.d. 7 Aug. 1614:

„The Dutch have paid the Queen for interest as followeth: - 
4 Mei was het voor Johor gekomen, en nadat het daar een paar weken had gelegen, kwam de Atjehsche vloot, die, zooals we boven zagen ${ }^{1}$ ), op 6 Juni de stad overweldigde. Waar een antal opvarenden van de Hoop, die als helpers der Johorieten aan de krijgsbedrijven hadden deelgenomen, mede gevankelijk naar Atjeh was gevoerd, vervolgde het schip zijn route naar Patani reeds met verzwakte bemanning. Maar door nog andere rampen werd het getroffen. Door een Westerstorm uit den koers geslagen, verviel het eerst aan de kust van Borneo, en belandde vervolgens bij Poeloe Condor. Daar het onmogelijk was om van hier Patani te bereiken, besloot de bemanning nu, naar kaap Varela, aan de Oostkust van Achter-Indië, te varen, ten einde te trachten, daar verversching te bekomen. Dit liep opnieuw op een groote teleurstelling en op nieuwe rampen uit: de inwoners aldaar namen een volstrekt vijandige houding aan, zoodat een aantal schepelingen aan land ,,doodt gesmeten” werd, terwijl anderen aan boord stierven. In allertreurigsten toestand kwam daarna, veel te laat, op 31 October de Hoop te Patani aan, met een voor 't meerendeel ziek te bed liggende bemanning.

Welken invloed de komst van het schip op den handel in Patani heeft gehad, heb ik uit de bronnen niet kunnen opmaken. Wel is het van belang, dat nu Hendrik Janssen, na als opperhoofd van het kantoor zijn beste krachten daaraan gegeven te hebben met de Hoop op 16 November 1613 uit Patani vertrok. 13 December daaraanvolgende kwam hij te Bantam aan ${ }^{2}$ ).

The first month 2 per cent. and 1 ditto the mint master, which is 3 per cent. for one month.

The next two months 3 per cent. and one to the mint master, which is 4 per cent. for 2 months.

The next 3 months 6 per cent. and one to the mint master, which is 7 per cent. for 3 months.

The next 6 months 10 per cent. and one to the mint master, which is [11?] per cent for 6 months.

A year's interest amounteth to 20 per cent. per annum". (Letters Received by the East India Company from its Servants in the East. Ed. F. C. Danvers and W. Foster, London, 1896-1902, dl. II, n 159).

1) Zie p. 71.

2) Vgl. over het voorgaande: Van Dijk: Borneo, p. 215 noot 2; Heeres: Hendrik Janssen, p. 115; MacLeod I, p. 116; Moreland, p. 75 v., 82, 85, 95, 97 v.; Copie-sententie van Mateo Coteels c.s., Bantam, 16 Febr. 1612 (geconfirmeerd door Pieter Both in een stuk van 25 Juli 1612); Hendrik Brouwer aan beww. te Amst., op 't schip de Roode Leeuw met Pijlen voor Bantam, 27 Juni 1612; Mateo Coteels aan Hendrik Janssen te Patani, $20 \mathrm{Mt}$. 1613; Hendrik Janssen aan Jacop die Schot te Bantam, Patani, 12 Oct. 1613; Abraham van den Broecke aan beww., Patani, 12 Oct. 1613; Hendrik Janssen aan beww. 
Ons kantoor in Siam was tijdens de bewindsperiode van Hendrik Janssen in Patani weinig belangrijk geweest. Dat het een tijd van malaise doormaakte, blijkt o.a. hieruit, dat men er minder leggers noodig achtte. Ellert Ellertsen ${ }^{1}$ ) was reeds spoedig weer vertrokken; 10 December $1611 \mathrm{kwam}$ hij in Bantam aan. En toen zich in het volgend jaar het schip Bantam voor Patani bevond, werd door den gecombineerden raad van 't kantoor en 't schip besloten, dat ook Cornelis van Nieuwenroode Siam moest verlaten en het opperbevel over de factorij aan Houtman alleen overlaten. Dat Nieuwenroode ongeschikt zou geacht zijn, lijkt weinig waarschijnlijk. Bontekoe, de man der vele avonturen, beschuldigt hem er weliswaar van, dat hij "gern zijn eygen hooft" wil volgen en ,geen vermaecken in 't gebet" heeft (!), maar Hendrik Janssen acht hem niet ongeschikt. En bovendien: later is Van Nieuwenroode in Siam opnieuw in functie geweest $^{2}$ ). Het besluit van 1612 moet dan ook veeleer aan een neiging tot bezuiniging worden toegeschreven. De overkomst van Van Nieuwenroode liet lang op zich wachten. Terwijl hij op 1 September zijn afscheid van den koning van Sian verkreeg, arriveerde hij pas 19 October in Patani, te laat om nog met de Bantam naar 't Zuiden te kunnen vertrekken ${ }^{3}$ ). Eerst bijna een jaar later, namelijk in October 1613, vertrok hij met het jacht Enkhuizen naar Bantam ${ }^{4}$ ).

Er werd door sommigen aan getwijfeld, of Ajudhja als kantoor van de Compagnie wel aangehouden moest worden; Van den Broecke verklaart op 12 October 1613 aan bewindhebbers, dat Siam hun nog weinig voordeel opgeleverd heeft. De onrustige toestanden, die er in het koninkrijk heerschten, werkten ook niet mee tot een kalm

te Amst., Bantam, 28 Dec. 1613; J. P. Coen aan beww. te Amst., Bantam, 1 Jan. 1614 (Col. Coen I, p. 1 v.); Twee brieven van Pieter Both aan beww., Bantam, 1 Jan. 1614; Copie-instructie voor de raden, gaande met de schepen de Zwarte Leeuw, de Galjas of andere naar Japan en Cochinchina, Jacatra, 23 April 1617 (Col. Coen II, p. 238 v.); de extract-brief van Van den Broecke, bedoeld op p. 23 , noot 2 .

1) Zie p. 60 .

2) Bovendien is hij in 1616 nog opperkoopman in Sangora geweest (J. P. Coen aan beww., Bantam, 10 Oct. 1616 - Col. Coen I, p. 191 v. -; Copiefactuur der goederen, door Hendrik Janssen geladen in de Galjas, Patani, 30 Oct. 1616). Ook heeft hij nog aan 't hoofd van 't Hollandsche kantoor in Japan gestaan als opvolger van Leonardt Camps, die in 1623 overleed (Nachod 5 Kap. Zweiter Abschnitt).

3) Vgl. p. 66.

4) Wanneer Van Nieuwenroode in een schrijven uit Ajudhja van 20 Sept. 1617 er op zinspeelt, dat hij vandaar vier jaren geleden is vertrokken, zullen we dus moeten begrijpen: uit die streken in 't algemeen. 
handelsbedrijf : herhaaldelijk was het land in oorlogen gewikkeld. Aldus werd de taak van Houtman, na het vertrek van Van Nieuwenroode alleen als bestuurder van 't kantoor Ajudhja overgebleven, uitermate ondankbaar. Herhaaldelijk klaagde hij in zijn brieven zijn nood over verwaarloozing door de Compagnie: het noodige kapitaal ontbrak steeds, de handel met de Chineezen kon daardoor niet naar behooren gedreven worden: hij verlangde zelfs, verlost te worden, daar op een kantoor, dat aan de Compagnie geen winst opleverde, geen eer voor den factorijhouder te behalen viel. Hij is echter ten slotte toch op zijn post gebleven, zelfs nog jaren nadat Hendrik Janssen in Patani plaats gemaakt had voor Abraham van den Broecke.

Een van de redenen, die het verblijf van Houtman in Ajudhja onaangenaam maakten, was ook het lang uitblijven der gezanten, die, zooals we boven zagen ${ }^{1}$ ), met Pieter Both naar Indië waren teruggereisd, en naar Patani waren gezonden om van daar naar Siam te gaan. Ze zijn in Patani echter blijkbaar langer vastgehouden dan hun aangenaam was. Een schrijven van Van Nieuwenroode en Houtman d.d. 2 September 1612 aan Hendrik Janssen is in dit opzicht instructief. Met het Engelsche schip de Globe was zekere „Ockonchijn" in Siam aangekomen, een dienaar van "Okonsiot”, die opdracht had, de klachten van zijn meester aan den koning te laten overbrengen. Okonsiot, dien we wel zullen moeten identificeeren met den vroeger genoemden Ockoncij ${ }^{2}$ ), had met de Globe willen vertrekken, maar was door de Hollanders, die dit wilden verhinderen, 4 à 5 dagen in 't schip Bantam in arrest gehouden, welke smaad hem tot zulk een toppunt van woede had gebracht, dat hij „sijn buijck door onpasienticheijt [had] willen open snijden". Men had hem verder laten zweren, dat hij niet met de Engelschen mee naar Siam zou varen, en hem ook in andere opzichten smadelijk behandeld. Zijn klacht schijnt echter niet tot den koning te zijn doorgedrongen. Toch vroeg deze, zooals begrijpelijk is, zelf herhaaldelijk aan de Hollanders naar het lot van zijn ambassadeurs.

Vanwaar dat krasse optreden der onzen in Patani, dat zoo weinig geschikt was, in Siam een stemming van vertrouwen te handhaven, die voor onzen handel zoo noodig was? Geheel duidelijk is dit niet, maar het wil mij schijnen, dat het resultaat van de wijdsch opgezette ambassade in Holland zóó poover was geweest, dat men dit voor

1) Zie p. 60.

2) (Vgl. p. 34), al zou de vorm Ockonchijn hiermee ook meer overeenkomen. Dit is echter blijkbaar een dienaar. 
den koning van Siam zoo lang mogelijk wilde geheim houden uit vrees, diens toorn op te wekken. De geheele onderneming had van 't begin af weinig enthousiasme bij de onzen gewekt, zooals immers reeds gebleken was, doordat men een der gezanten niet mee naar Holland had laten gaan, maar in Bantam had achtergehouden ${ }^{1}$ ). En nog in Maart 1613 zinspeelt Coteels er op, dat Hendrik Janssen opgescheept zit ,met 3 caele ambasadeurs" ${ }^{2}$ ).

Ten slotte nog een enkel woord over Japan. Het ligt allerminst in mijn bedoeling, onzen handel met dit land in bijzonderheden na te gaan; gelijk ik echter, sprekende over het bestuur van Victor Sprinckel in Patani, vermeldde, hoe door den tocht van de Roode Leeuw met Pijlen en de Griffioen onze geregelde handelsbetrekkingen met Japan begonnen ${ }^{3}$ ), zoo wil ik er nu op wijzen, dat tijdens het bestuur van Hendrik Janssen, en wel in 1612, deze betrekkingen eveneens van Patani uit gesteund werden door het zenden van een eindelijk bevredigend cargasoen. Dit was voorzeker laat genoeg! Het grootscheepsche begin van 1609 had bij de Japanners verwachtingen gewekt, waaraan geen gevolg was gegeven. Het jacht de Brak, dat Japanin 1611 bezocht ${ }^{4}$ ), had daar maar een klein cargasoen gebracht. De positie van Specx was aldus hoe langer hoe lastiger geworden; hij kon moeilijk bestrijden, dat de factorij van Hirado door de Compagnie bepaald verwaarloosd werd. Maar eindelijk kwam er beter-

1) Zie p. 34 v.

2) Vgl. over de Siamsche zaken: Van Dijk: Wemmer van Berchem, p. 32 noot 3;; Groeneveldt, p. 89, noot 2; Moreland, p. 95; Mateo Coteels aan Hendrik Janssen te Patani, Bantam, 20 Mt. 1612; Ellert Ellertsz. de Jonge aan Hendrik Janssen te Patani, 20 Mt. 1612; Victor Sprinckel aan Hendrik Janssen te Patani, Bantam (er staat foutief Patany boven), 20 Mt. 1612; Cornelis van Nieuwenroode en Marten Houtman aan Hendrik Janssen te Patani, Ajudhja, 3 Mei 1612; Hendrik Brouwer aan beww. te Amst., op 't schip de Roode Leeuw met Pijlen voor Bantam, 27 Juni 1612; Cornelis van Nieuwenroode en Marten Houtman aan Hendrik Janssen, Ajudhja, 2 Sept. 1612; Marten Houtman aan Hendrik Janssen te Patani, Ajudhja, 20 Sept. 1612; Copiebrief van Jacques Specx aan Cornelis van Nieuwenroode en Marten Houtman te Ajudhja, Firando, 3 Nov. 1612; Marten Houtman aan Hendrik Janssen te Patani, Ajudhja, 5 Nov. 1612; idem aan denzelfde, Ajudhja, 7 Dec. 1612; idem aan denzelfde, Ajudhja, 26 Dec. 1612; Copiebrief van Marten Houtman aan Hendrik Janssen te Patani, Ajudhja, 18 Mt. 1613; Mateo Coteels aan Hendrik Janssen te Patani, 20 Mt. 1613; Hendrik Janssen aan Jacop die Schot te Bantam, Patani, 12 Oct. 1613; Abraham van den Broecke aan beww., Patani, 12 Oct. 1613; Cornelis van Nieuwenroode aan de kamer van Amst., Ajudhja, 20 Sept. 1617; Inventaris van de negotieboeken, per Leiden naar patria gezonden.

3) Zie p. 48 v.

4) Zie p. 56 v. 
schap door middel van het jacht de Hazewind, dat, zooals we reeds zagen ${ }^{1}$ ), op 13 Juli 1612 van Patani naar Japan koers zette.

Coteels had van Bantam uit Hendrik Janssen er met nadruk op gewezen, hoeveel er voor onze reputatie in Japan af zou hangen van het eerste cargasoen van beteekenis, dat hij daarheen zou zenden. Janssen moest daarom slechts de beste kwaliteiten naar dit land inschepen, zoowel van zijde en zijden lakenen, die bij beschikbaar had, als ook van porselein van alle sorteeringen.

Inderdaad werd de handel op Japan nu in 't groot aangepakt: uit de factuur, door Hendrik Janssen op 12 Juli 1612 onderteekend, leeren we, welk een belangrijk cargasoen in Patani in de Hazewind voor Japan werd ingescheept: dit beliep, alles samengerekend, het aanzienlijke bedrag van f $26187.9 .15^{2}$ ). Hieronder vielen zoowel goederen, welke Janssen van zijn voorganger Victor Sprinckel had overgenomen, als die, welke hij zelf had ingekocht. $Z$ ijde en andere stoffen bekleeden in deze factuur een belangrijke plaats; porselein wordt er echter niet in aangetroffen, wel peper. Dat onze Japansche belangen deze groote goederenzending rechtvaardigden, zou de toekomst dubbel en dwars bewijzen ${ }^{3}$ ).

d. Abraham van den Broecke en het derde bewind van Hendrik Janssen (1613-1618).

We zagen boven, dat, toen Hendrik Janssen op 16 November 1613 met het schip de Hoop uit Patani vertrok ${ }^{4}$ ), Abraham van den Broecke daar als zijn opvolger achterbleef, en ook, dat deze laatste een allesbehalve gunstige reputatie genoot ${ }^{5}$ ). In Patani wist men er al van mee te spreken. Bij zijn bezoek aldaar in $1612^{6}$ ) had Van den Broecke er een „concubijne” op na gehouden, welke hij voor zijn vertrek ,magnificquement gecleet” aan iemand anders had „overgedaen”.

1) Zie p. 65 .

2) Een copie bevat een paar onbeduidende correcties op dit getal, waardoor het geheel slechts een paar gulden lager zou moeten worden gesteld.

3) Vgl. over den Japanschen handel: Nachod, p. 149 v.; Mateo Coteels aan Hendrik Janssen te Patani, Bantam, 20 Mt. 1612; Mateo Coteels aan Hendrik Janssen te Patani, Bantam, 25 Mt. 1612; idem an denzelfde, Bantam, 17 April 1612; Factuur van Hendrik Janssen van de goederen, geladen in 't jacht de Hazewind, Patani, 12 Juli 1612.

4) Zie p. 74 .

5) Zie p. 72 v.

6) Zie p. 72. 
Ook bij zijn optreden nu als opperhoofd van het kantoor was het klaarblijkelijk zijn bedoeling, zijn leven zoo aangenaam en behagelijk mogelijk in te richten. Hij had, zoo schrijft Both aan bewindhebbers, uit Bantam ,,een vercken ${ }^{1}$ ) wijn tot sijn behoeff” meegenomen; uit Macassar had hij een paard meegebracht; hij had getracht, van Patani uit door bemiddeling van een aanzienlijk persoon uit die plaats nog een tweede paard uit Macassar te krijgen. Dit was den Pataniër evenwel mislukt, ,waerover hij clen persoon zeer schobbeerde ende trotselijck toegesproken heeft". Voor het paard, dat hij bezat, liet Van den Broecke een toom met zilveren beslag maken, „omme alsoo heerl. ${ }^{2}$ ) ende magnificquement te hooff te comen". Uit de sloep Klein Enkhuizen ${ }^{3}$ ) had hij, speciaal ten behoeve van zijn paard, een bootsman genomen, die met paarden kon omgaan. Maar dit is niet alles. „Hij hout daer”, zoo hooren we verder van Both, „,een camer apart, daer niemant en mach incomen dan sijnen swerten jongen, die hij mede in Neerlandt heeft gehadt, ende nu tot Patani op dieverije bevonden is geweest”. En, summum van aanstootelijkheid, hij ,hout daer een jonge $\operatorname{sogh}^{4}$ ), die daer (met reverentie) gebaggelt ${ }^{5}$ ) heeft, ende om het huijs lopen, het welcke de moren voor een groot affgrijselijckheijt houden" ${ }^{6}$ ).

Both, die erkende, dat hij er met de keuze van Van den Broecke was ingeloopen, vond het dan ook noodig, aan diens onzalig bestuur een eind te maken; hij besloot, hem terug te roepen van zijn post, om hem elders te gebruiken, op een plaats ,bij de handt, daer men sijn superbe procedures can sien ende in remedieren". Zijn aangewezen opvolger scheen.... Hendrik Janssen! Dezen, hoewel pas van Patani teruggekomen, zou men trachten weer voor den post van opperhoofd te winnen, als zijnde ,,aldaer wonder bemindt, bekent ende ervaren" 7). Janssen echter, reeds geruimen tijd uit zijn vaderland afwezig geweest zijnde, verlangde daarheen terug, en eerst ,naer veel weijgeringhe" liet hij zich wederom voor drie jaren in Compagniesdienst aannemen op f 110 per maand. Hij vertrok met het jacht

1) Een soort vat.

2) Lees : heerlijck.

3) Hiermee bedoeld het jacht Enkhuizen, waarmee hij gekomen was (zie p. 73) of een daarbij behoorende sloep?

4) Zeug.

5) Gebigd.

6) Pieter Both aan beww., Bantam, 1 Jan. 1614.

7) Zie Van Dijk: Borneo, p. 215 noot 2; J. P. Coen aan beww. te Amst., Bantam, 1 Jan. 1614 (Col. Coen I, p. 1 v.); Pieter Both aan beww., Bantam, 1 Jan. 1614. 
Jacatra naar zijn vroegere standplaats, en kwam daar 17 Mei aan ${ }^{1}$ ).

Zoo was de rol van Abraham van den Broecke in Patani niet meer dan een kort, zij 't dan ook opzienbarend intermezzo geweest. Nog was ' $t$ met zijn carrière in Indië niet afgeloopen. Wel moeten goede dienaren in dien tijd schaarsch geweest zijn, dat hem toch wederom een nieuwe functie werd toegedacht, namelijk die van opperkoopman in Johor, waar hij f 126 per maand zou ontvangen, meer dus nog dan Hendrik Janssen in Patani! Inderdaad werd hij 10 October 1615 per jacht de Aeolus met een partijtje kleeden als lading door Coen c.s. naar zijn nieuwe plaats van bestemming gezonden. Maar bewindhebbers, aan wie natuurlijk van den Broecke's gedragingen niet onbekend waren gebleven, hadden geen geduld meer met hem: ze verlangden zijn terugzending naar patria, en Coen voldeed aan deze lastgeving. Uit een schrijven van hem aan bewindhebbers d.d. 31 Maart 1616, gezonden met 't jacht de Dolphijn, leeren we, dat Van den Broecke met dit jacht werd overgezonden, tegelijk met eenige bezwarende processtukken, waaruit de heeren nadere kennis over zijn wangedragingen zouden kunnen putten ${ }^{2}$ ).

Van Mei 1614 tot October 1618 zou nu Hendrik Janssen aan een stuk door het gezag in Patani uitoefenen. Hij is dan ook degene, die door zijn ervaring ter plaatse, door herhaalde en langdurige diensten, door onmiskenbare bekwaamheid de meest markante figuur in deze factorij geweest is. En deze laatste dienstperiode van hem is ook de belangrijkste: de Compagnie stond in deze jaren voor moeilijke kwesties en belangrijke beslissingen; na de wilde jacht op winst werd organisatie een gebiedende eisch. En één man komt juist in die jaren, al is 't eerst nog in ondergeschikte positie, meer en meer op den voorgrond, een man, bij uitstek bekwaam om deze organisatie met kracht ter hand te nemen en aan ieder onderdeel zijn juiste plaats in het groote geheel te geven: Jan Pieterszoon Coen. Te vragen, welke plaats nu op den duur Patani in dit geheel zou moeten be-

1) Heeres : Hendrik Janssen, p. 115 v.; Hendrik Janssen aan beww. te Amst., Bantam, 28 Dec. 1613; Pieter Both aan beww., Bantam, 1 Jan. 1614; Hendrik Janssen aan beww. te Amst., Patani, 20 Oct. 1614. Heeres vermeldt niets van de redenen, waarom Van den Broecke ongeschikt werd geacht. Verder is Heeres' veronderstelling, dat Hendrik Janssen bij zijn nieuwe aanstelling den rang van opperkoopman verkreeg, onjuist. Deze titel komt reeds eerder voor.

2) Zie: Extract uit 't reg. van resolutiën, gehouden in den Raad van Indië, fort Nassau in Banda, 23 Mei 1615; J. P. Coen aan beww., Bantam, 22 Oct. 1615 (Col. Coen I, p. 114 v.) ; Copie-res. van J. P. Coen c.s., waarschijnlijk Bantam, 4 Mt. 1616; J. P. Coen aan beww., Bantam, 31 Mt. 1616 (Col. Coen I, p. 175 v.). 
kleeden, zou zijn de kwestie verkeerd stellen: de preliminaire vraag was, óf Patani er een plaats in zou moeten bekleeden; het werd voor onze factorij een ,to be or not to be”. We zien dan ook voor ons onderwerp de geschiedenis van deze jaren voornamelijk als een samenspel van Janssen en Coen, dat eventueel tot een strijd zou kunnen worden. In dezen strijd zou Janssen, die natuurlijke verdediger van zijn factorij, die voor een deel zijn schepping genoemd kon worden, zich natuurlijk hebben te schikken naar de belangen van het algemeen. De beslissing viel weliswaar pas na Janssen's bewind, maar hoe die zou moeten uitvallen, scheen in 1618 voor scherpe waarnemers reeds niet twijfelachtig.

We hebben gezien, hoe in vroegeren tijd Patani te lijden had gehad onder onvoldoende bezoek van Hollandsche schepen. Wat dit nu betreft had Janssen in de jaren 1614-1618 niet te klagen: tal van keeren verschenen schepen of jachten op de reede. Het schijnt me wenschelijk, eerst een opsomming hiervan te geven: vanzelf wordt dan reeds een en ander duidelijk omtrent de richtingen, waarin de Patanische handel ging; daarna zijn dan enkele algemeene gezichtspunten omtrent dien handel op hun plaats.

In 1614 werd Patani in de eerste plaats bezocht door het jacht Jacatra, dat, zooals we reeds boven zagen, met Hendrik Janssen aan boord, op 17 Mei aldaar aankwam. Terwijl dit jacht voor Patani ter reede lag, verscheen uit Bantam op 27 Juni het schip de OudZeelandia, dat last had gekregen, de plaats aan te doen om er een lading goederen voor Japan in te schepen. Inderdaad werd o.a. een partij zijde geladen, waarna op 5 Juli beide schepen gezamenlijk naar Japan vertrokken.

Verder kwam in dit jaar nog het schip Rotterdam, in Mei van fort Oranje op Ternate afgezonden naar Patani, om daar goederen voor Bantam in te nemen. Hendrik Janssen laadde er diensvolgens in, wat 't jaar 1614 als retour voor Bantam had opgeleverd. We weten, dat op 20 October in Patani de bedoeling was, vijf dagen later het schip Zuidwaarts te zenden. Inderdaad is het op 2 December te Bantam gearriveerd ${ }^{1}$ ).

In het jaar 1615 kwam op 10 April het jacht Jacatra terug uit

1) Vgl. over de schepen in Patani in 1614 o.a.: Laurens Reael aan beww., fort Oranje op Ternate, 20 Juni 1614; Hendrik Janssen aan beww. te Amst., Patani, 20 Oct. 1614; J. P. Coen aan beww. te Delft, Bantam, 27 Dec. 1614 (Col. Coen I, p. 97 v.). Zie over de Oud-Zeelandia en de Jacatra ook nog noot 2 volgende pag.

Verh. dl. I. 
Japan, terwijl op 3 Juli voor Patani het schip Enkhuizen verscheen, dat uit Bantam was gezonden met eindbestemming naar Japan. Ook was gerekend met de mogelijkheid, dat de Enkhuizen een Portugeesche kraak zou kunnen buitmaken; jaarlijks voer er namelijk een dergelijk schip van Macao naar Nagasaki ${ }^{1}$ ), een begrijpelijkerwijze welkom jachtdoel voor de Nederlanders ${ }^{2}$ ). Den $13^{\text {en }}$ Juli gingen de Jacatra en de Enkhuizen gezamenlijk op weg naar Japan ${ }^{3}$ ), na beide voor deze bestemming een lading voor Specx, onzen opperkoopman in Firando, te hebben ingekregen.

In 1616 was, evenals in de beide voorafgaande jaren, het jacht Jacatra weder het eerste schip, dat men in Patani te zien kreeg: het kwam, evenals in 1915, uit Japan, ja zelfs op denzelfden datum: 10 April. Een paar maanden daarna, op 9 Juni, kwam uit Bantam het schip de Zwarte Leeuw, dat bestemd was voor Japan, en daarbij, evenals de Enkhuizen in het vorige jaar, op de kraak van Macao te letten had. Samen vertrokken nu op 24 of 25 Juni de Jacatra en de Zwarte Leeuw met een lading goederen voor Japan naar 't NoordOosten. De Jacatra werd in haast weer vandaar teruggezonden naar Patani, omdat men, ten onrechte, meende, dat het jacht noodig zou zijn om het daar voor Bantam aanwezige cargasoen over te brengen. 27 October kwam het aldus weer voor Patani aan. Het trof daar echter reeds een ander schip, de Galjas van Hoorn, dat er $25 \mathrm{Juli}$ was aangekomen uit Jambi, waarheen men dit schip van Jacatra uit had gezonden. De bedoeling was geweest, dat Galjas met de Zwarte Leeuw mee te zenden naar Japan, ook al in verband met het aanvalsplan tegen de Portugeesche kraak. We weten echter, dat de Zwarte Leeuw bij ankomst van de Galjas in Patani reeds ongeveer een maand geleden vertrokken was. Hendrik Janssen hield het schip nu bij zich, om er een cargasoen voor Bantam in te laden. Samen vertrokken nu de Jacatra en de Galjas, waarschijnlijk omstreeks begin

1) Vg1. p. 49.

2) Van Engelsche zijde is beweerd, dat ook reeds in 1614 een dergelijke kraak in 't oog was gevat door de Oud-Zeelandia en de Jacatra (Letters Received II, $\mathrm{n}^{\circ}$ 167).

3) Vgl. over de schepen in 1615 o.a.: Copie-res. van pres. van Bantam en Jacatra en raden, Bantam, 1 Juni 1615 (Col. Coen III, p. 341 v.) ; Copiebrief van J. P. Coen aan Hendrik Janssen, Bantam, 10 Juni 1615 (Col. Coen II, p. 10 v.); Copie-factuur der goederen, door Hendrik Janssen geladen in 't jacht Jacatra, Patani, 11 Juli 1615; Copie-factuur der goederen, door Hendrik Janssen gescheept in 't schip Enkhuizen, Patani, 12 Juli 1615; Copiebrief van Hendrik Janssen aan 't kantoor te Bantam, Patani, 15 Nov. 1615; J. P. Coen aan beww., Bantam, 31 Mt. 1616 (Col. Coen I, p. 175 v.). 
November, uit Patani naar Bantam, terwijl ze onderweg Jambi nog aandeden ${ }^{1}$ ).

In 1617 werd Patani wederom bezocht door twee van de schepen, die er in 1616 ook geweest waren, namelijk de Galjas en de Zwarte Leeuw. Ook dit jaar was weer de bedoeling, tegelijk met de Patanische de Japansche belangen te behartigen, en voor de derde maal een poging te doen, de kraak van Macao in handen te krijgen. Maar nog een verder punt moest door den tocht der beide schepen behartigd worden: het aanknoopen van betrekkingen met Cochinchina - bedoeld is ongeveer Annam, zie hdst. III -, ja zelfs het vestigen van een kantoor aldaar. Om Hendrik Janssen spoedig aan contanten te helpen tot inkoop van peper en Chineesche waren, zond Coen op 17 April de Galjas uit Jacatra vooruit, terwijl spoedig daarna, op zijn vroegst den $23^{\text {en }}$ April, de Zwarte Leeuw volgde. Over de uitvoering en de verdeeling der verschillende werkzaamheden, waarvoor beide schepen bestemd waren, was Coen zoo verstandig, zich niet met al te imperatieve bijzonderheden uit te laten: daar alle omstandigheden niet vooruit bekend konden zijn, moest men in Patani en in Japan eenige vrijheid van beslissing hebben. 17 Mei kwam de Galjas te Patani aan, den $23^{\text {en }}$ of den $25^{\text {en }}$ ook de Zwarte Leeuw. $30 \mathrm{Mei}$ werden beide schepen naar Japan gezonden. 20 Juni bevonden ze zich in de buurt van Macao. Wat de Galjas betreft, deze lag 30 December voor Firando. Het schip is niet weer naar Patani teruggekeerd. Wel is dit het geval met de Zwarte Leeuw, die op 12 October voor Firando lag en toen bestemd was, vandaar via Patani naar Bantam te vertrekken. In November is de Zwarte Leeuw aldus weer in Patani geweest, en vandaar, waarschijnlijk 21 November of kort

1) Vgl. over de schepen in 1616 o.a.: Copie-res. van pres. v. Bantam en Jacatra en Raden, Bantam, 3 Mei 1616 (Col. Coen III, p. 362 v.); Copiebrief van J. P. Coen aan Hendrik Janssen te Patani, Bantam 14 Mei 1616 (Col. Coen II, p. 98 v.) ; Copie-instructie van J. P. Coen voor opperkoopman en schipper van de Zwarte Leeuw, Bantam, 14 Mei 1616 (Col. Coen II, p. 113 v.); Copiebrief van J. P. Coen aan Andries Soury te Jambi, 26 Mei 1616 (Col. Coen II, p. 119 v.); Copie-instructie van J. P. Coen voor opperkooplieden en schippers van de Galjas en de Bergerboot, Jacatra 26 Mei 1616 (Col. Coen II, p. 121 v.); Copie-res. van kantoor Patani, schip Z warte Leeuw en jacht Jacatra, Patani, 21 Juni 1616; Copie-factuur der goederen, door Hendrik Janssen gescheept in 't schip Zwarte Leeuw en 't jacht Jacatra, Patani, 24 Juni 1616; J. P. Coen aan beww., Bantam, 10 Oct. 1616 (Col. Coen I, p. 191 v.) ; Hendrik Janssen aan beww. te Amst., Patani, 25 Oct. 1616; Copiebrief van Hendrik Janssen aan J. P. Coen, Patani, 25 Oct. 1616; J. P. Coen an beww., Bantam, 10 Dec. 1616 (Col. Coen I, p. 234 v.); Copiebrief van J. P. Coen aan C. van Nieuwenroode te Sangora, Jacatra, 17 April 1617 (Col. Coen II, p. 230). 
daarna, naar Bantam vertrokken, waar zij 11 December arriveerde ${ }^{1}$ ).

In 1618 is Patani door drie schepen bezocht, en wel 't eerst door het schip de Zwarte Leeuw en het jacht Jacatra, welke op 5 April samen van Jacatra waren vertrokken. De bedoeling was, hoewel ook hier de voorschriften niet al te bindend waren gemaakt, dat de Zwarte Leeuw het retour, voor patria bestemd, moest terugbrengen, terwijl het jacht onze belangen in Cochinchina moest behartigen. 11 Mei kwamen de beide schepen in Patani aan. De Jacatra vertrok nog in dezelfde maand volgens het advies van Coen naar Cochinchina. Het heeft daar evenwel niets kunnen verrichten, en zette daarop koers naar Japan. De rol van het jacht, dat we reeds zoo dikwijls in Patani hebben aangetroffen, zou evenwel spoedig uitgespeeld zijn: in de buurt van Formosa stuitte het op vijf Portugeesche fregatten en kwam hiermee in gevecht. Daarbij raakte de Jacatra in brand en sprong tengevolge daarvan uiteen.

Terwijl de Zwarte Leeuw voor Patani lag, kwam daar op 12 October het jacht Hollandia, ook Klein-Hollandia genaamd, dat expres uit Jacatra via Jambi was gezonden om in de behoefte aan rijst te voorzien. In Cambodja en omliggende streken moest het trachten, hiervan een lading op te doen. Verder bracht het order van Coen, dat de $Z$ warte Leeuw bij het terugkeeren niet naar Bantam, maar naar Jacatra moest gaan. Samen met de Zwarte Leeuw is het jacht Hollandia spoedig na zijn aankomst weer van Patani vertrokken. Wij komen op dezen tocht, die, wat de $Z$ warte Leeuw betreft, een rampzalig verloop gehad

1) Vgl. over de schepen in 1617 o.a.: Van Dijk: Borneo, p. 347; Copie-res. van J. P. Coen c.s., Jacatra, 16 April 1617 (Col. Coen III, p. 393 v.); Copiebrief van J. P. Coen aan Hendrik Janssen te Patani, Jacatra, 17 April 1617 (Col. Coen II, p. 226 v.); Copie-res. van J. P. Coen c.s., Jacatra, 21 April 1617 (Col. Coen III, p. 395); Copiebrief van J. P. Coen aan Jacques Specx in Japan, Jacatra, 23 April 1617 (Col. Coen II, p. 232 v.); Copie-instructie voor de raden, gaande met de Zwarte Leeuw, de Galjas of andere naar Japan en Cochinchina, Jacatra, 23 April 1617 (Col. Coen II, p. 238 v.); Copie-ress., genomen te Patani door raadspersonen van 't kantoor en de Zwarte Leeuw en de Galjas, Patani, 26 Mei 1617; J. P. Coen aan beww., Jacatra, 22 Aug. 1617 (Col. Coen I, p. 249 v.); Factuur der goederen en koopmanschappen, door Jacques Specx geladen in de Zwarte Leeuw, Firando, 12 Oct. 1617; Copiebrief van Hendrik Janssen aan J. P. Coen te Bantam, Patani, 25 Oct. 1617; J. P. Coen aan beww., Bantam, 18 Dec. 1617 (Col. Coen I, p. 290 v.); Copiebrief van J. P. Coen aan commandeur 't Lam in de Molukken, Bantam, 30 Dec. 1617 (Col. Coen II, p. 321 v.); Copie-instructie van Jan Dircxen Lam voor Jan Berchoudt, pres. over de Oude Zon en de Galjas, Firando, 30 Dec. 1617; Copiebrief van J. P. Coen aan G. F. Druyff te Patani, in de Zierikzee aan de eilanden van Jacatra, $30 \mathrm{Mt}$. 1618 (Col. Coen II, p. 365 v.). 
heeft, nader terug. De Hollandia is 12 December 1618 weer voor Jacatra teruggekeerd ${ }^{1}$ ).

Bracht het bezoek van al de genoemde schepen voor Hendrik Janssen tal van werkzaamheden mee, ook overigens moest hij veel overzien en belangrijke beslissingen mee nemen. Zoo stond immers ook het kantoor van Sangora ${ }^{2}$ ) onder zijn oppergezag; hij had aldus den plicht, den handel aldaar zoo goed mogelijk tot bloei te brengen, zonder nogtans daardoor onze belangen in 't hoofdkantoor Patani te schaden. In 1614 bracht hij met Van Nieuwenroode een bezoek bij den koning van Sangora, welke de geheele macht over deze plaats had overgekregen van zijn vader, den koning van Ligor, die dus afstand van zijn souvereiniteitsrechten over Sangora had gedaan. De jonge koning bleek niet alleen bereid, onze verkregen rechten te bevestigen, maar schonk zelfs een nieuw contract, dat aan de Nederlanders nog grootere zekerheid gaf. In verband met de veelbelovende vooruitzichten vatte Hendrik Janssen nu 't plan op, er een nieuw, steenen huis te laten bouwen ${ }^{3}$ ).

In 't begin van 1616 duurde het optimistische gevoelen van Hendrik Janssen omtrent ons kantoor in Sangora nog onverminderd voort: hij bezocht toen den koning van Ligor op diens verzoek, en kon zich

1) Vgl. over de schepen in 1618 o.a.: Van Dijk: Borneo, p. 230 noot 3 en p. 347; Heeres: Hendrik Janssen, p. 120; Copiebrief van J. P. Coen aan Hendrik Janssen te Patani, in 't schip Zierikzee, liggende aan de eilanden van Jacatra, 30 Mt. 1618 (Col. Coen II, p. 360 v.); Copie-res. van pres. en raden, Jacatra, 3 Sept. 1618 (Col. Coen III, p. 453 v.); Copiebrief van J. P. Coen aan Hendrik Janssen en Druyff te Patani, Jacatra, 4 Sept. 1618 (Col. Coen II, p. 423 v.); Copiebrief van Gerrit Frederiksz. Druyff aan beww., Patani, 4 Oct. 1618; Factuur van 't cargasoen, door Hendrik Janssen geladen in de Zwarte Leeuw, Patani, 15 Oct. 1618; Copiebrief van Gerrit Frederiksz. Druyff aan beww., Patani, 1 Nov. 1618; J. P. Coen c.s. aan beww., in 't schip de Oude Zon, liggende voor Mandalique, omtrent 3 mijlen bij Oosten Japara, 14 Jan. 1619 (Col. Coen I, p. 416 v.); Copiebrief van Cornelis van Nieuwenroode aan Jacques Specx in Firando, Ajudhja, 31 Mei 1619; Copiesententie van G.-G. en raden, fort Jacatra, 27 Juni 1619 (Col. Coen IV, p. 169 v.); Notitie van de schaden en intresten door de O. I. C. geleden bij de Engelschen en door hun toedoen sedert het begin van de krakeelen tot het begin van de "twintichjaarige vereeninge”.

2) Zie p. $67 \mathrm{v}$.

3) Of dit spoedig hierna geschied is, weet ik niet; het lijkt mij niet waarschijnlijk. Het plan wordt namelijk door Hendrik Janssen eerst genoemd in een brief van 20 Oct. 1614, terwijl de boekwaarde van de gezamenlijke huizen in Sangora en Siam in een balans van de Compagnie d.d. 3 Nov. 1614 (hierbij kan dus nog niet van het nieuwe huis sprake zijn) even hoog gesteld wordt als in dergelijke opgaven van $30 \mathrm{Juli} 1615,18$ Dec. 1615 en 29 Febr. 1616, namelijk $f 2350$ (het huis in Patani is in al deze vier stukken gesteld op f 3525 ). 
toen verheugen in het, ,goet acces ende succes ter cause van 't comptoor in Sangora by hen ende synnen zoone als souvrain heer van Sangora ende Bordelong". Ten einde deze goede verhouding te doen voortbestaan, zoo schrijft Janssen aan bewindhebbers van Amsterdam, zouden slechts eenige curiosa uit ons land noodig zijn, waarmee men nu eenmaal in die streken - we zagen het vroeger in verband met Siam - bij de vorsten met geringe kosten veel gunsten kon verwerven. Wat Ligor en Sangora betreft, waren „eenige calcoenen, swaenen, conijnnen ende Islantsche hondtgies" gewenscht, alsmede goedkoope schilderijen van „lantschappen, veltslagen, vogelstruisen, naer ' $t$ leven geschildert, ende andere drollicheden". Of ook nu weer niet voldoende op deze wenschen gelet werd? Zeker is het, dat ook in het kantoor van Sangora op den duur de moeilijkheden voor onzen handel niet uitbleven. Mocht nog in September 1617 Van Nieuwenroode uit Ajudhja naar Amsterdam schrijven, dat de Chineezen zeer gezind waren, in Sangora te komen handelen, in 1618 was dit anders. In dat jaar, zoo vernemen we uit Patani, werden de Chineezen zeer willekeurig behandeld. In Ligor en Sangora werden van regeeringswege de aangebrachte waren uit jonken der aangekomen Chineezen gehaald en even autoritair de prijs daarvoor vastgesteld : voor de ruwe zijde, die 180 à 190 realen op de vrije markt had kunnen opbrengen, werd door den koning ${ }^{1}$ ) ,en sijnen kaelen adel” 80 à 90 in peper of andere waren betaald, ,welcke scheeringe haer dickwils doet achter blijven". En wat voor zin had ons kantoor in Sangora, als er geen Chineezen kwamen! ${ }^{2}$ ).

Ook over den handel in Siam moest Hendrik Janssen telkens zijn gedachten laten gaan. Van bijzonder belang was in dit verband de vraag, hoe men den jongen en veelbelovenden handel op Japan, waarvoor Siam immers juist de meest geschikte invoerartikelen leverde ${ }^{3}$ ), op de meest practische wijze zou regelen. Een belangrijk besluit in

1) Van Ligor?

2) Vg1. over de betrekkingen tot Sangora: Hendrik Janssen aan beww. te Amst., Patani, 20 Oct. 1614; Balans van 't generale boek, Bantam, 3 Nov. 1614; J. P. Coen aan beww. te Delft, Bantam, 27 Dec. 1614 (Col. Coen I, p. 97 v.) ; Copic-factuur der goederen, door Hendrik Janssen gescheept in 't schip Enkhuizen, Patani, 12 Juli 1615; Balans van 't generale boek, Bantam, 30 Juli 1615; idem, Bantam, 18 Dec. 1615; idem, Bantam, 29 Febr. 1616; Hendrik Janssen aan beww. te Amst., Patani, 25 Oct. 1616; Copiebrief van Hendrik Janssen aan J. P. Coen, Patani, 25 Oct. 1616; Cornelis van Nieuwenroode aan kamer Amst., Ajudhja, 20 Sept. 1617; Copiebrief van Gerrit Frederiksz. Druyff aan beww., Patani, 4 Oct. 1618.

3) $\mathrm{Zie}$ p. 20 en 50 . 
dit opzicht werd in 1614 genomen, toen de Jacatra en de OudZeelandia voor Patani ter reede lagen. Coen, toen Directeur-Generaal van den handel in Bantam, die zelf den bovengenoemden handel van veel belang vond, had opdracht gegeven, speciaal over de regeling hiervan een besluit te nemen. Ampel overleg had nu plaats tusschen de raadspersonen van 't kantoor Patani en die van de Oud-Zeelandia, alsmede den schipper van 't jacht Jacatra, samen acht personen, waaronder ook Jacques Specx, dien we reeds in Japan bezig gezien hebben. Niet minder dan vier plannen werden met elkaar vergeleken; het resultaat was de resolutie van $1 \mathrm{Juli}$, die de volgende strekking had. Twee maal per jaar zouden de goederen uit Siam, voor Japan bestemd, met een jonk naar Sangora of Patani worden gebracht. Jaarlijks zou daar dan een groot schip uit Bantam de Siamsche waren inladen, om ze naar Japan te vervoeren. Dit schip zou dan in April uit Bantam moeten vertrekken, en, zooals Hendrik Janssen in October 1614 schrijft, in Mei of 't eerst van Juni in de bocht van Patani aankomen, omdat anders de hertevellen daar te lang zouden moeten liggen en ,van de wormen door de langduyrighe tijt gegeten ende bedorven souden worden" 1 ). Coen vond de in Patani getrokken resolutie zeer goed, en had nu de taak, mede voor de uitvoering ervan te zorgen. In de practijk echter bleek deze groote moeilijkheden mee te brengen. Reeds de eerste poging om de resolutie van 1614 te effectueeren liep op een mislukking uit. Coen had hiervoor in 1615 het schip Enkhuizen bestemd, dat, zooals we weten, op 3 Juli in Patani aankwam ${ }^{2}$ ). De jonk van Siam, welke de voor Japan gewenschte waren moest aanbrengen, kwam echter te laat, zoodat de Enkhuizen, na tot 13 Juli gewacht te heblen, naar Japan vertrok, vreezende, bij langer toeven den gunstigen moesson te zullen verzuimen. Elf dagen daarna kwam de jonk aan, met een lading van \pm 10000 hertevellen en 900 picol sappan ,ofte roodthout”. Nadat deze goederen in Sangora waren gelost, werd de jonk dadelijk naar Siam teruggezonden; 14 November verscheen ze met een nieuwe lading voor Japan, bestaande uit 1400 picol sappanhout. En volgens schrijven van Houtman uit Siam kon in Mei 1616 bovendien een lading van \pm 1300 picol sappanhout en 5000 hertevellen worden verwacht. Dit alles zou samen, met wat er ondertusschen nog bij gekomen zou zijn,

1) Heeres: Hendrik Janssen, p. 117, geeft ten onrechte den indruk, alsof Hendrik Janssen niet de hand in dit besluit zou gehad hebben en van 't begin af sceptisch tegenover deze methode zou hebben gestaan.

2) Zie p. 82 . 
een behoorlijke scheepslading voor Japan kunnen vormen voor het jaar 1616. Maar ondertusschen was het plan voor 1615 mislukt: en wat meer zegt: Hendrik Janssen was door deze poging van meening veranderd omtrent de resolutie van 1614: de methode had toch volgens hem bij nader inzien te veel nadeelen : aan schenkages moest te veel worden betaald; ook de andere onkosten vielen te hoog: voor de twee reizen van de jonk alleen al meer dan f 4300 ! Verder liepen de maandgelden der Hollandsche opvarenden te veel op, 't vele lossen en laden bracht nadeelige „lackagien" ${ }^{1}$ ), en vooral: de hertevellen stonden te veel bloot aan bederf. Bij aankomst van de jonk in Juli was bijna een derde part ervan bedorven en door wormen aangetast gebleken (de reis van Siam naar Patani had bijna 21/2 maand geduurd!). Het oordeel van Hendrik Janssen wordt bevestigd door Cornelis van Nieuwenroode, die, naar we boven zagen ${ }^{2}$ ), in 1616 opperkoopman in Sangora is geweest, en deze functie ook waarschijnlijk reeds in 1615 bekleed heeft. Hij werd in dat jaar door Hendrik Janssen met de meermalen genoemde jonk naar Siam gezonden om daar poolshoogte te nemen omtrent den handel op Japan. Zijn conclusie is, evenals die van Hendrik Janssen, ongunstig ten opzichte van de resolutie van 1614 .

Een der methoden, waaraan ook reeds in dat jaar was gedacht, bestond in 't zenden van een schip uit Bantam, dat én Patani én Siam zou kunnen aandoen, om dan vandaar de aanwezige goederen rechtstreeks naar Japan te brengen. Dit procédé was toen bij de beraadslagingen in Patani als de onzekerste methode beschouwd, daar het onmogelijk zou zijn, dat het schip tijdig (begin Mei) Patani zou kunnen verlaten om naar Siam door te gaan. Na de teleurstelling, in 1615 met de Enkhuizen opgedaan, komt Hendrik Janssen er echter op terug: hij had weliswaar de resolutie van 1614 mee onderteekend, maar kan natuurlijk toen reeds een afwijkende persoonlijke meening hebben gehad. 15 Mei 1615 schrijft hij naar Bantam, dat hem een doorgaande scheepstocht heel goed mogelijk lijkt, wanneer het schip half Mei in Patani zou kunnen aankomen. Coen toonde zich ontvankelijk voor Janssen's raad, maar er werden bezwaren tegen diens plan ingebracht door Houtman in Siam, die o.a. daarbij moeilijkheden voorzag bij den inkoop van sappanhout.

En inderdaad is ook deze tweede methode voor den handel van Siam op Japan ten slotte niet als de juiste beschouwd. Er ontstond

1) D.i.: wat daardoor van de goederen verloren gaat.

2) Vgl. p. 75 noot 2 . 
tusschen onze factorijen in deze twee landen een directe handelsverbinding, die onafhankelijk was van de vaart op Patani. Hiervoor moest een jonk dienen, welke in 1615 door het jacht Jacatra onder Japan op de Portugeezen werd veoverd, en voortaan ,de Hoop”. heette. Jacques Specx, die dit vaartuig onder zijn berusting had, gebruikte het voor den handel op Siam. Reeds in Juni 1616 is het, naar we weten, van Siam naar Japan vertrokken met een lading van \pm 3000 picol sappanhout, \pm 14000 hertevellen en andere dienstige waren, samen ter waarde van f 14567.9 .10 . In dezelfde maand viel in Patani een resolutie, volgens welke de Hoop ook verder, voorzien van Japansch scheepsvolk, den handel tusschen Japan en Siam moest waarnemen. In 1617 werd er door Houtman reeds een lading van f 32270.17 .8 mee naar Japan verzonden. Coen, hoewel deze oplossing blijkbaar niet ideaal vindende, berichtte toch in April 1617 aan Specx, dat hij tot nader order met de directe tochten van de Hoop op Siam moest doorgaan.

We hebben den Japanschen handel tot dusver gezien in 't licht van de importmogelijkheden aldaar. Hij had echter ook een anderen kant, die speciaal voor Patani van groote beteekenis werd geacht: den uitvoer van Japansch zilver. Kon deze in ruime mate geschieden, dan zou het minder noodig, op den duur zelfs misschien geheel onnoodig zijn, realen uit Bantam naar ,de bocht” te zenden. Met 't Japansche zilver zou men én van de Maleiers de peper, én van de Chineezen de zijde kunnen koopen. In 1614 en 1615 werd, op last van Coen, de proef genomen door middel van het jacht Jacatra, dat uit Japan een lading zilver in Patani moest brengen, waarmee dan onze factorijhouders het voor hun inkoopen in 1615 moesten stellen. Tengevolge van deze opdracht ontving Hendrik Janssen 10 April 1615 met het jacht Jacatra een waarde van f 52008.8 .12 aan Japansch zilver. Het bleek echter, dat het handelen hiermee groote moeilijkheden voor hem meebracht. Hij beklaagt zich in een brief van November 1615 aan Coen, dat 't Japansche zilver wel 6 à $7 \%$ verlies oplevert, ,door de onsuijverheijt, die 't noch bij hem heeft', hoewel 't ook al in Japan gefineerd was, waarop reeds $13 \%$ verlies was geleden. Ongeveer een jaar later herhaalt hij zijn klachten. In October 1616 schrijft hij, dat het handelen met Japansch zilver in Patani ,groote cnoijerie" is. Nadat het door smelten tot een zoo hoog gehalte was opgevoerd, dat het wel 3 à $3 \frac{1}{2} \%$. beter was dan realen van achten, weigerden de Maleiers, het tegen het zelfde gewicht aan te nemen: zij eischten de van ouds bekende realen 
van achten of Patanisch goud. En ook de Chineezen wilden al evenmin aan het Japansche zilver ${ }^{1}$ ).

Ook op de Nederlandsche belangen in Cambodja had Hendrik Janssen natuurlijk te letten, en tevens op die in Cochinchina, waar, zooals we zagen, het in de bedoeling lag, een Compagnieskantoor te stichten. Ik hoop op dit laatste punt nog terug te komen; alleen zij er hier reeds op gewezen, dat alweer het bemachtigen van de kostbare Chineesche artikelen hier de drijfveer was. Het scheen toch, dat men deze beter in Cochinchina zou kunnen verkrijgen dan in Patani.

We mogen ons in dit verband af vragen : zou, indien deze nieuwe toeleg gelukte, het kantoor van Patani nog reden van bestaan hebben?

Inderdaad, de factorij liep reeds toen gevaar. De bewindhebbers, die tegen 't sluiten van 't Bestand hadden aangedrongen op ' $t$ stichten van zoo veel mogelijk kantoren, werden later ongerust, dat de Compagnie te veel uit haar kracht zou groeien ${ }^{2}$ ). Duidelijke taak spraken

1) Vgl. over de rol van Patani t.o.v. Japan: Heeres: Hendrik Janssen, p. 117 v. ; Copie-ress. van raden v. schip Oud Zeeland met den schipper v. jacht Jacatra en die van 't kantoor in Patani, Patani, 1 Juli 1614; Hendrik Janssen aan beww. te Amst., Patani, 20 Oct. 1614; J. P. Coen aan beww., Bantam, 10 Nov. 1614 (Col. Coen I, p. 52 v.); J. P. Coen aan beww. te Delft, Bantam, 27 Dec. 1614 (Col. Coen I, p. 97 v.); Copiebrief van J. P. Coen aan Jacques Specx, Bantam, 10 April 1615 (Col. Coen II, p. 1 v.); Copie-res. van pres. van Bantam en Jacatra en raden, Bantam, 1 Juni 1615 (Col. Coen III, p. 341 v.) ; Copiebrief van J. P. Coen aan Jacques Specx, Bantam, 10 Juni 1615 (Col. Coen II, p. 5 v.); J. P. Coen aan beww., Bantam, 22 Oct. 1615 (Col. Coen I, p. 114 v.); Copiebrief van Hendrik Janssen aan 't kantoor te Bantam, Patani, 15 Nov. 1615; J. P. Coen aan beww., Bantam, 31 Mt. 1616 (Col. Coen J, p. 175 v.); Copiebrief van J. P. Coen aan Hendrik Janssen te Patani, Bantam, 14 Mei 1616 (Col. Coen II, p. 98 v.); Copie-memorie van J. P. Coen over wat Jacques Specx van Japan zenden moet, Bantam, 14 Mei 1616 (Col. Coen II, p. 114 v.); Copie-factuur van wat door Marten Houtman in de jonk de Hoop gescheept is, Siam, 8 Juni 1616; Copie-res. van raad van kantoor Patani, schip Zwarte Leeuw en jacht Jacatra, Patani, 21 Juni 1616; Hendrik Janssen aan beww. te Amst., Patani, 25 Oct. 1616; Copiebrief van Hendrik Janssen aan J. P. Coen, Patani, 25 Oct. 1616; Copiebrief der XVII aan J. P. Coen, Amsterdam, 26 Nov. 1616 (Col. Coen IV, p. 351 v.); Copiebrief van J. P. Coen aan Hendrik Janssen te Patani, Jacatra, 17 April 1617 (Col. Coen II, p. 226 v.) ; Copiebrief van J. P. Coen aan Jacques Specx in Japan, Jacatra, 23 April 1617 (Col. Coen II, p. 232 v.) ; Cornelis van Nieuwenroode aan kamer Amst., Ajudhja, 20 Sept. 1617; Copiebrief van Hendrik Janssen aan J. P. Coen te Bantam, Patani, 25 Oct. 1617; J. P. Coen aan beww., Bantam, 18 Dec. 1617 (Col. Coen I, p. 290 v.); Vervolg van de partijen van de generale boeken in Indië, Jacatra 11 Mt.-15 Juni 1618; Copiebrief van Cornelis van Nieuwenroode aan Jacques Specx in Firando, Ajudhja, 31 Mei 1619; Extract uit een brief van Houtman in Siam.

2) Vgl. mijn artikel: Bezuinigingsmaatregelen van Jan Pietersz. Coen, in Tijdschrift voor Gesch., 1934, p. 15 v. 
Heeren VII in een brief aan Coen d.d. 21 November 1614: „Wy bevinden groote swaricheyt voor de Compagnie in de menichfuldicheyt van alle de cantoiren in de Indien, soo overmits de groote costen in 't onderhoudt derselver alsoock in de perijckulen, die op onse in sooveel plaetsen verstroyde goederen dagelijcx vallen, behalven dat oock door verstroyinge van onse middelen in sooveele plaetsen geene van al de plaetsen van soodanich capitael en kan geprovideert werden, als tot den nodichsten handel soude van nooden wesen, want terwyle alle dese nieuwe coopluyden een yder practiseert, om in syn quartieren eenigen grooten handel voorts te stellen, soo treckt elcx sooveel middelen naer hem, als hy kan, sonder eens te letten, als 't al gecocht is, off het oock ter plaetsen daer 't gesonden werdt, in sulcker abondantie sal kunnen vertiert ende geconsumeert werden, nochte oock off de middelen van de Compagnie bastandt sijn, om in alle de quartieren soo grooten handel te dryven".

Coen is, wat Patani betreft, voorloopig nog gunstig gestemd. Dat dit kantoor, zoo schrijft hij omstreeks denzelfden tijcl aan bewindhebbers, niet meer winsten heeft afgeworpen, is eraan te wijten, dat het niet behoorlijk van contanten en koopmanschappen voorzien is. Maar „Patane van capitalen versien wesende soo connen aldaer, ende noch beter in Sangora, daer mede een comptoir gestabileert is, een goet cargasoen Chinese waren becomen, tot beteren pryse dan alhier tot Bantam; connen wy van U.E. contanten becomen, soo hopen wy dat de comp ${ }^{n}$ van $d^{0}$ quartieren seer goeden dienst sal geschieden". Consequent is Coen op dit punt niet gebleven: in 1616 lijkt hem voor den Chineeschen handel Bantam beter dan Patani, in 1617 wint Patani het weer, maar slechts vergelijkenderwijs : groot zal ook daar deze handel noqit worden; om 't ware succes te hebben, zal men in China zelf of althans ,naeder by de wercken" moeten wezen. En zijn waarschuwing in 1616 aan Janssen om vooral niet veel geld aan vertimmering te besteden, heeft een onheilspellend karakter! Zeer ongunstig is zijn oordeel over 't nut van Patani in 1618. Wij weten dit uit een schrijven van hem aan Andries Soury te Jambi. „Bij desen verclare”, aldus Coen, „hoe groot ende machtich Siam ende Patana sijn, soo en connen nochtans in d' Indischen staet van de Vereenichde Nederlanden qualijck een enckelde steen verstrecken, daer d' armoede van Jambi een goede pilare begint te sijn".

Geen wonder, dat Hendrik Janssen langzamerhand den bodem onder zich voelde wankelen. En, minder in staat om de proporties te zien dan Coen, trachtte hij het voortbestaan van de factorij, die 
voor een goed deel zijn schepping was, te verzekeren. In 1616 schreef hij aan Coen, dat het mogelijk zou zijn, Patani en Sangora met geringe kosten aan te houden: voor Patani zou men kunnen volstaan met een opper- en een onderkoopman met nog drie andere Hollanders. Dezen zouden dan rijkelijk hulp kunnen krijgen van getrouwe Maleiers en Chineezen, die slechts in naam onder Hollandsch gezag zouden behoeven te staan; Sangora zou 't kunnen stellen met een onderkoopman of een kloek assistent, geholpen door twee inlanders. Het contant zou in Patani kunnen berusten, zoo, dat ook Sangora er, als 't noodig was, mee kon worden geholpen. Een soortgelijk schrijven richtte Janssen aan bewindhebbers te Amsterdam. Een zwaar wegend argument voor 't aanhouden der twee factorijen was ook nog, dat, als de onzen zich er uit zouden terugtrekken, dit maar al te graag gezien zou worden door de Engelsche concurrenten, die er onmiddellijk hun voordeel mee zouden doen ${ }^{1}$ ).

Maar hoe Hendrik Janssen ook mocht pleiten om het kantoor van Patani te redden, hij moet wel allengs het gevoel hebben gekregen van iemand, die voor een verloren zaak strijdt. En het was, als moest de ongunst van de natuur den toch al bedenkelijken toestand van de factorij nog verergeren. Zoo had de peperhandel vreeselijk te lijden door overstroomingen, die jaar op jaar de peperplanten ${ }^{2}$ ) ontwortelden en wegrukten. De slapte in dezen handel, die reeds heerschte, toen Janssen zijn tweede bewindsperiode in 1614 begon, duurde nog voort in 't najaar van 1617, toen er nog heel weinig Patanische peper te krijgen was; wel trachtte men door aanplant op groote schaal van nieuwe boomen de productie weer op 't oude peil te brengen, maar dit kon eerst later zijn volle uitwerking hebben.

En verder werd de handel in Chineesche artikelen op noodlottige wijze belemmerd door zware stormen, waardoor tot tweemaal toe de

1) Vgl. over 't bovenstaande: Tiele Eur. 5 II, p. 241; Heeres: Hendrik Janssen, p. 117 v.; Res. XVII in hun vergadering van 19 Mt. 1614 ; J. P. Coen aan bew., Bantam, 10 Nov. 1614 (Col. Coen I, p. 52 v.); Copiebrief van de XVII aan J. P. Coen, Amsterdam, 21 Nov. 1614 (Col. Coen IV, p. 287 v.); Copiebrief van J. P. Coen aan Hendrik Janssen te Patani, Bantam, 14 Mei 1616 (Col. Coen II, p. 98 v.) ; J. P. Coen aan beww., Bantam, 10 Oct. 1616 (Col. Coen I, p. 191 v.) ; Hendrik Janssen aan beww. te Amst., Patani, 25 Oct. 1616; Copiebrief van Hendrik Janssen aan J. P. Coen, Patani, 25 Oct. 1616; Copiebrief van J. P. Coen aan Hendrik Janssen te Patani, Jacatra, 17 April 1617 (Col. Coen II, p. 226 v.); Copiebrief van J. P. Coen aan Jacques Specx in Japan, Jacatra, 23 April 1617 (Col. Coen II, p. 232 v.); J .P. Coen aan beww., Bantam, 18 Dec. 1617 (Col. Coen I, p. 290 v.); Copiebrief van J. P. Coen aan Andries Souri te Jambi, Jacatra, 21 Mei 1618 (Col. Coen II, p. 385 v.).

2) De peper is een plant, die tegen latten, bamboes of boomstammetjes opklimt. 
jonken, die tusschen China en de streek van Patani voeren, geteisterd werden. En wanneer er toevallig uit een aangekomen jonk iets goeds voor de Nederlanders te koopen was, dan had men vaak gebrek aan realen of goud om de gewenschte goederen te betalen. En evenals vroeger wendde men zich dan tot de koningin om een nieuw crediet op te nemen. We zagen reeds, hoezeer een man als Coen deze methode afkeurde ${ }^{1}$ ), die tot nadeel van onze reputatie strekte, en bovendien geen geringe kosten meebracht ${ }^{2}$ ). Toch bleef men van dit noodmiddel gebruik maken, ook onder de nieuwe koningin, die in 1616 aan de regeering kwam. Den $28^{\text {en }}$ Augustus van dat jaar stierf namelijk koningin Pratiau, na een regeering van 32 jaren; ze werd door haar zuster opgevolgd ${ }^{3}$ ).

Bij alle bezwaren, die Hendrik Janssen ondervond, kwam nog, dat zijn gezondheidstoestand onbevredigend was. Op de reis, die hij in 1616 ondernam naar Ligor, om onze handelsbelangen in Sangora te bevorderen ${ }^{4}$ ), had hij een ziekte opgedaan, die hem verder voortdurend in zijn werk belemmerde, gelijk zoo velen in dien tijd bij de rudimentaire toestanden op 't punt van tropen-hygiëne door den dienst in Indië ernstige schade aan hun gezondheid leden. „Het schijnt”, aldus Coen, ,dat de wagen in dese quartieren al craeckende voort moet”. Janssen wilde daarom ,,verlost” worden en eindelijk, na 19-jarigen dienst, zijn vaderland terug zien. 25 October 1616 zond hij zijn verzoek om ontslag aan Coen; het liefst zou hij de reis doen als koopman op een schip, ,alsoo niet geerne voor doot eeter naer patria soude keeren". Hij zou echter desnoods, al was 't ook

1) Zie p. 64 .

2) We treffen in een factuur van 1617 een geval aan, waar voor een leening van 4000 realen van achten f 234.15 .3 aan onkosten betaald wordt! Zie ook p. 73 noot 5 .

3) Zie over het bovenstaande: Moreland, p. 62 v.; Tiele Eure 5 II, p. 241; Heeres : Hendrik Janssen, p. 119; Hendrik Janssen aan beww. te Amst., Patani, 20 Oct. 1614; Copiebrief van J. P. Coen aan Jacques Specx, Bantam, 10 April 1615 (Col. Coen II, p. 1 v.); J. P. Coen aan beww., Bantam, 22 Oct. 1615 (Col. Coen I, p. 114 v.); Copiebrief van Hendrik Janssen aan 't kantoor Bantam, Patani, 15 Nov. 1615; J. P. Coen aan beww., Bantam, 31 Mt. 1616 (Col. Coen I, p. 175 v.); Hendrik Janssen aan beww. te Amst., Patani, 25 Oct. 1616; Copiebrief van Hendrik Janssen aan J. P. Coen, Patani, 25 Oct. 1616; Cornelis van Nieuwenroode aan de kamer van Amst., Ajudhja, 20 Sept. 1617; Prijscourant van koopmanschappen, Patani, Sept. 1617; Copiebrief van Hendrik Janssen aan J. P. Coen te Bantam, Patani, 25 Oct. 1617; Factuur der koopmanschappen, door Hendrik Janssen gescheept in de Zwarte Leeuw, Patani, Nov. 1617.

4) Zie p. 85 . 
niet zijn wensch, nog korten tijd in Patani willen blijven. Dit nu strookte zeer met de plannen van Coen. Janssen, zoo dacht deze, was niet gemakkelijk te vervangen. Toch zou zijn verzoek om ontslag moeten worden toegestemd; veel zou er echter gewonnen zijn, als de opvolger eenigen tijd onder Janssen's toezicht stond, om dan eerst na diens vertrek de geheele leiding van 't kantoor in handen te nemen. 17 April 1617 verzoekt Coen aldus in een schrijven aan Janssen, nog een jaar te willen blijven, „opdat interim den nieuwen coopman practica become". Daarna hoopte hij samen met Janssen naar patria terug te keeren. En volgens dezen brief, waaruit de vriendschappelijke gevoelens van Coen voor den factorijhouder duidelijk aan 't licht treden, is ook inderdaad in Patani gehandeld.

Nog over twee andere mutaties werd gesproken in den brief, waarin Hendrik Janssen aan Coen zijn ontslag vroeg. Ten eerste had hij provisioneel zekeren Jan van Hasel als onderkoopman in Patani aangesteld, ter vervanging van Matthijs de Mere, die hem vijf jaar als zoodanig had gediend, ,een cloeck ende getrouw jongman" volgens Jansen. En verder had ook Houtman, de factorijhouder te Ajudhja in Siam, zijn ontslag gevraagd. Als opvolger kwam in aanmerking Cornelis van Nieuwenroode, toentertijd hoofd van 't kantoor in Sangora ${ }^{1}$ ), en die, zooals we al gezien hebben, ook reeds in Siam was geweest, en dus over de noodige ervaring voor zijn nieuwen post beschikte ${ }^{2}$ ). Coen kon zich met beide benoemingen vereenigen.

Belangrijker is voor ons echter de vraag, wie tot opvolger van Hendrik Janssen zelf bestemd werd. Dit was Gerrit Frederiksz. Druyff, die in Mei 1617 met de Zwarte Leeuw te Patani aankwam ${ }^{3}$ ). Bijna had het geschenen, dat men het kantoor een tweeden Abraham van den Broecke op den hals had geschoven. Bewindhebbers althans hadden berouw, hem te hebben uitgezonden: een missive uit patria van 5 Maart 1616 meldde, dat volgens ontvangen inlichtingen Druyff ,gansch onbequaem ende in den coophandel onervaren, daerenboven tot den dronck genegen soude wesen". Spoedige terugzending zou raadzaan kunnen zijn. $\mathrm{Nu}$ is 't wel meer voorgekomen, dat bewindhebbers een te alarmistischen kijk hadden op de bruikbaarheid van naar Indië uitgezonden personen. Over een der grootsten, Antonio van Diemen, zou later dezelfde bange twijfel heerschen, zoodat uit

1) Vgl. p. 75 noot 2.

2) Vgl. p. 60.

3) Zie p. 83 . 
patria naar Indië waarschuwend werd gemeld, dat hij behoorde tot de ,gedebaucheerde quanten.... die ofte alhier gefailleert sijn ofte hun andersints groflick hebben verloopen"; streng toezicht op hem zou daarom raadzaam zijn ${ }^{1}$ ). Wat Druyff betreft, deze bleek, evenals later Van Diemen, beter dan zijn reputatie. Reeds in 1616 werd hij op last van Reael als gezant van de Compagnie naar den Mataram gezonden. Ook Coen was het niet met 't oordeel van bewindhebbers eens: „Alsoo”, dus schrijft hij, ,niet onbehoorlijck van Gerrit Fredericxsen Druyff vernomen hebben, is denselven naer Patana gesonden tot verlossingh van den oppercoopman Hendricq Janssen". En zoo begon na de aankomst van de Zwarte Leeuw in 1617 te Patani een soort condominium, waarbij Hendrik Janssen als mentor van zijn opvolger optrad en voorloopig het oppergezag nog in handen hield.

Nog bijna anderhalf jaar lang is hij met zijn opvolger in Patani samen geweest; in het najaar van 1618 vertrok hij op ongeveer 45-jarigen leeftijd ${ }^{2}$ ) als opperhoofd van de $Z$ warte Leeuw en het jacht Hollandia, na het bestuur over de kantoren Patani, „Ligoor ofte Sangora" en Ajudhja aan Druyff te hebben overgegeven. Het was een triomfantelijk slot van een lange lijdensgeschiedenis: juist in 't laatst van zijn bewindsperiode was de handel ongewoon goed geslaagd, zoodat een rijke lading ter waarde van f 152119.17 .2 , o.a. bestaande uit zijde, peper en rijst aan boord van de $Z$ warte Leeuw naar 't Zuiden verscheept kon worden. Druyff kon ternauwernood zijn jaloezie verbergen over 't feit, dat Hendrik Janssen deze gunstige conjunctuur nog had meegemaakt en aldus met de eer van 't succes zou gaan strijken! Eerst nadat deze op de $Z$ warte Leeuw was vertrokken, zou hij de gelegenheid krijgen, zijn bekwaamheden te toonen.

Wat Janssen betreft, het laatste deel van zijn Indische carrière was het meest bewogene. In den tijd van zijn vertrek uit Patani gingen de golven van de Compagniesgeschiedenis buitengewoon hoog: de felle concurrentie met de Engelschen, die tot gewapend conflict werd, de strijd om het fort Jacatra (de wordingsgeschiedenis van ons algemeen rendez-vous Batavia) brachten én in Indië én in patria een beklemmende spanning teweeg. En in deze kwesties was

1) Dr. H. T. Colenbrander: Koloniale Geschiedenis (Den Haag, 1925-1926), d1. II, p. $141 \mathrm{v}$.

2) In een copie-attestatie door de opperhoofden van de $Z$ warte Leeuw over 't nemen van dit schip door de Engelschen wordt van Hendrik Janssen gezegd, dat hij op 12 Juli 1619 omtrent 46 jaar oud is. 
Hendrik Janssen een der meest in 't oog vallende dramatis personae, al was soms zijn rol geen heldenrol. Al dadelijk begint zijn reeks van avonturen met het verlies van zijn kostelijk beladen schip de Zwarte Leeuw, dat hem door de Engelschen op listige wijze afhandig werd gemaakt ${ }^{1}$ ).

Later werd Hendrik Janssen de afgezant van den rijksbestuurder van Bantam, toen deze trachtte, door onderhandeling het benarde fort Jacatra in handen te krijgen, Jacatra, dat reeds in principe was overgegeven aan Engelschen en Jacatranen. Dat de plaats voor de onzen behouden bleef tot de triomfantelijke terugkomst van Coen met zijn schepen van Ambon, is werkelijk niet aan Janssen te danken, die eerst de overgave aan Bantam dringend had aanbevolen, en later, toen men 't over de definitieve voorwaarden niet eens kon worden, de weigering van de Nederlanders niet aan den rijksbestuurder durfde over te brengen en in Jacatra bleef.

Beide gevallen, waarin Janssen gefaald had, zijn stellig groote teleurstellingen voor Jan Pietersz. Coen geweest, die dan ook zijn ongenoegen daarover niet onder stoelen en banken stak.

Maar men heeft aan Hendrik Janssen gelegenheid gegeven tot eerherstel. Veelzeggend in dit opzicht is de volgende resolutie van gouverneur-generaal en raden van 2 Juli 1619: „Alzoo wel hoognodig een bequaam persoon met de schepen den Engel, de Bergerboot, de Morgensterre ende de Jager naar Jamby ende Patana diend te gaan, om op de Engelse te passen ende de handel aldaar te helpen vervorderen, waar toe $S^{r}$ Hendrik Janssen zijnen dienst is presenterende, om zijn eere te repareeren ende revenge van de Engelsche te bekomen, ende gemerkt zijne goede diensten voor deesen gedaan en de goede hope die nog van deselve zijn hebbende, vermits in die quartieren seer ervaren is, niet tegenstaande de groote faulte met de Zwarten Leeuw gecommitteerd, is goedgevonden, om hem niet ten enemaal met deese faulte van zijne vorige dienst te discourageeren, dat den voorschreven Hendrik Janssen als Commandeur met de voorschreven scheepen sal mede gaen". De onderneming liep uit op een glorieus slot van Janssen's Indische carrière: bij de reede van Patani wist hij twee Engelsche schepen, de Sampson en de Hound genaamd, te vermeesteren. Hij werd beloond met een gouden ketting van 600 gulden en vertrok op eervolle wijze naar het vaderland, namelijk als

1) Op de kwesties tusschen Nederlanders en Engelschen zal ik, voor zoover die in onmiddellijk of verwijderd verband met Patani staan, nader terug moeten komen in hoofdstuk VII. 
commandeur en opperkoopman op het schip Dordrecht, dat in 't laatst van Januari of 't begin van Februari van Bantam naar patria vertrok.

Hiermee nemen we afscheid van Hendrik Janssen, die, welke schaduwzijden zijn Indische loopbaan ook mag toonen, een markante figuur uit onze periode van opkomst zal blijven: een man van groote bekwaamheden, een getrouw werker, die meer dan iemand anders zijn naam aan de door hem geleide factorij van Patani verbonden heeft. Niet aan hem is het te wijten, dat in een tijd van algemeene opkomst Patani meer en meer ten ondergang gedoemd was. Gelukkig voor hem, dat hij dezen ondergang niet meer bijwoonde: de geschiedenis van onze factorij gaat ook na hem door. Maar deze geschiedenis maakt op ons den indruk van een epiloog ${ }^{1}$ ).

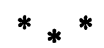

\section{e. Het bewind van Gerrit Frederiksz. Druyff (1618-1621).}

Toen Hendrik Janssen in 't najaar van 1618 op de tot ongeluk voorbestemde $Z$ warte Leeuw zee had gekozen, kreeg Druyff gelegenheid, zijn eigen bekwaamheden te toonen en in volle zelfstandigheid de factorij van Patani te besturen. Hij heeft dat, zoover we kunnen

1) Vg1. over den afloop van Hendrik Janssen's bewind: De Jonge IV, p. XXXIV; Heeres: Hendrik Janssen, p. 119 v.; Copiebrief der kamer Amsterdam aan Reynst, Raden van Indië en Coen, 5 Mt. 1616 (Col. Coen IV, p. 340 v.); Hendrik Janssen aan bewindhebbers te Amst., Patani, 25 Oct. 1616; Copiebrief van Hendrik Janssen aan J. P. Coen, Patani, 25 Oct. 1616; Copiebrief van de XVII aan Coen, Amsterdam, 9 Dec. 1616 (Col. Coen IV, p. 366 v.); Copie-res. van J. P. Coen c.s., Jacatra, 16 April 1617 (Col. Coen III, p. 393 v.); Copiebrief van J. P. Coen aan Hendrik Janssen, Jacatra, 17 April 1617 (Col. Coen II, p. 226 v.) ; Copiebrief van J. P. Coen aan Hendrik Janssen te Patani, Jacatra, 23 April 1617 (Col. Coen II, p. 236 v.); J. P. Coen aan beww., Jacatra, 22 Aug. 1617 (Col. Coen I, p. 249 v.); Copiebrief van Hendrik Janssen aan J. P. Coen te Bantam, Patani, 25 Oct. 1617; Copiebrief van J. P. Coen aan G. F. Druyff te Patani, in de Zierikzee aan de eilanden van Jacatra, 30 Mt. 1618 (Col. Coen II, p. 365 v.) ; Copiebrief van Gerrit Frederiksz. Druyff aan beww., Patani, 4 Oct. 1618; Copiebrief van Gerrit Frederiksz. Druyff aan beww., Patani, 1 Nov. 1618; Copiebrief van J. P. Coen aan Reael te Amboyna, Jacatra, 30 Dec. 1618; J. P. Coen c.s. aan beww., in Oude Zon, liggende voor Mandalique omtrent 3 mijlen bij Oosten Japara, 14 Jan. 1619 (Col. Coen I, p. 416 v.) ; J. P. Coen aan beww., Jacatra, 5 Aug. 1619 (Col. Coen I, p. 445 v.); Cognossement van Hendrik Janssen, in 't schip Bantam onder Poele Panjangh omtrent Bantam, 30 Jan. 1620; Beschrijving, hoe de Engelschen in 1618 tegen ons een generalen oorlog aangevangen hebben enz.; Copie-attestatie door de opperhoofden van de $Z$ warte Leeuw, hoe deze door de Engelschen genomen is. 
nagaan, met ijver en energie gedaan, niet als iemand, die een bijna verloren post verdedigt, maar met levendigheid, nog spiedende naar nieuwe mogelijkheden van handelswinst. Hij toont zich in zijn brieven onderhoudend en dikwijls, vooral als hij geëmotioneerd wordt, zeldzaam slagvaardig en geestig.

Ook wat dit laatste tijdvak betreft, wil ik beginnen met na te gaan, door welke schepen Patani werd bezocht. Het best gebeurt dat ook hier weer door jaar na jaar in beschouwing te nemen.

In 1619 vertrok, zooals we boven ${ }^{1}$ ) zagen, niemand minder dan Hendrik Janssen naar 't Noorden met een kleine vloot, bestaande uit de schepen de Bergerboot, de Engel en de jachten de Morgenster en de Jager, waarbij immers getracht moest worden, wraak op de Engelschen te nemen voor het gebeurde ten aanzien van de $Z$ warte Leeuw. Op 4 Juli uit Jacatra vertrokken, kwamen de schepen 13 Juli voor Jambi aan, wat de eigenlijke bestemming van de Jager was. De drie overige vaartuigen zetten nu koers naar Patani, dat ze op 26 Juli bereikten. De Engel voer van hier volgens instructie door naar Japan, na deelgenomen te hebben aan 't reeds genoemde roemrijke gevecht tegen de Engelsche schepen Sampson en Hound. De Bergerboot en de Morgenster bleven nog tot 6 November, en vertrokken toen weer naar Jacatra, waar ze 10 November arriveerden.

Maar nog voor de genoemde vloot was een ander schip uit Jacatra naar Patani gezonden, en wel 't jacht Klein Hollandia, dat we reeds uit 't jaar 1618 kennen $^{2}$ ). Dit jacht moest geld in Patani brengen, en tevens zoo noodig militaire hulp bieden: het Portugeezengevaar was namelijk acuter geworden, doordat de Pataneezen met het ons zoo vijandige volk vrede hadden gesloten, iets, waarop we nader terug komen. Het jacht zou in dit verband een tijdlang in Patani en omliggende kwartieren gebruikt kunnen worden. Op 2 Juni werd het uit Jacatra afgezonden; het heeft onderweg Jambi aangedaan, en is vandaar nog in de eerste helft van Juni weer vertrokken; de datum, waarop het voor Patani verscheen, is ons niet bekend; we weten echter, dat 't daar zeer welkom was, dat het zijn geld drie mijlen ten Oosten van de stad loste, en daarna de rivier van Sangora binnenliep. Toen Hendrik Janssen op 6 November uit Patani vertrok met de Bergerboot en de Morgenster en zijn twee Engelsche prijzen, bleef de Klein Hollandia daar (of in Sangora) nog liggen ${ }^{3}$ ).

1) Pag. 96.

2) Zie p. 84 .

3) Vgl. omtrent de schepen in 1619 o.a.: Copiebrief van J. P. Coen aan 
Het jaar 1620 bracht nog eens voor Patani een ongekend levendige scheepvaart: men moet teruggaan tot 1602 , den tijd, waarin de concurrentie van verschillende maatschappijen nog haar invloed deed gelden, om een dergelijk scheepsbezoek aan te treffen. Ten onrechte zou men dit echter als een bewijs van hernieuwden bloei der factorij opvatten: de schepen, welke in 1620 kwamen, hebben voor 't grootste gedeelte niet alleen Patani bezocht, maar ook verder gelegen handelsplaatsen. Ondanks het groote aantal gegevens omtrent de scheepvaart in 1620 doet zich de moeilijkheid voor, dat we lang niet volledig den tijd van 't verblijf der verschillende vaartuigen in Patani kunnen vaststellen. Op 15 of 17 Februari 1620 verscheen onverwachts uit Siam het jacht de Vos, dat door Druyff voorloopig in Patani gehouden werd. Daarna zond hij het jacht weer naar Siam, met verdere bestemming naar Cambodja, waar het een zeer belangrijke rol zou spelen. Van dezen tocht kwam de Vos op 3 November weer in Patani terug.

13 of 17 Mei kwam de Sampson in Patani het belangrijke bericht brengen, dat er vrede tusschen de Engelsche en de Nederlandsche compagnieën was gesloten. 21 April was het schip van Jacatra vertrokken. Druyff zond het verder naar Siam, vanwaar het op 29 October opnieuw in Patani kwam. Van daar is het naar Jacatra vertrokken, welke plaats het op 12 of 13 December bereikte.

Het was toen in gezelschap van het schip de Zeewolf, dat na de Sampson uit Jacatra naar Patani was vertrokken, namelijk $15 \mathrm{Mei}$, waarbij het last had, onderweg Jambi aan te doen. 13 Juni kwam het in Patani en werd daarop naar Sangora gezonden. Waarschijnlijk is het schip op 4 November of kort daarna van Patani naar Jacatra

Gerrit Frederiksz. Druyff, Jacatra, 2 Juni 1619 (Col. Coen II, p. 555 v.) ; Copieinstructie van $J$. P. Coen voor koopman en schipper varende met 't jacht Klein Hollandia naar Patani, Jacatra, 2 Juni 1619 (Col. Coen II, p. 563); Copie-res. van G.-G. en Raden, in 't schip de Trouw voor Bantam, 10 Juni 1619 (Col. Coen III, p. 514 v.); Copiebrief van J. P. Coen aan Jacques Specx te Firando, jacatra, 2 Juli 1619 (Col. Coen II, p. 570 v.); Copie-instructie van J. P. Coen voor Hendrik Janssen en raad van de Engel, Bergerboot, Morgenster en Jager, Jacatra, 2 Juli 1619 (Col. Coen II, p. 575 v.) ; Copie-commissie van J. P. Coen, Jacatra, 3 Juli 1619 (Col. Coen II, p. 578 v.); Copiebrief van Adriaen Jacobs van der Dussen aan Coen, 25 Juli 1619; J. P. Coen aan beww., Jacatra, 5 Aug. 1619 (Col. Coen I, p. 445 v.); J. P. Coen c.s. aan beww., Jacatra, 22 Jan. 1620 (Col. Coen I, p. 508 v.); Copiebrief van Pieter de Carpentier ,ter ordonnantie van d'heer generael" aan Gerrit Frederiksz. Druyff te Patani, Jacatra, 21 April 1620 (Col. Coen II, p. 688 v.); Jan van Hasel aan J. P. Coen te Jacatra, Sangora 4 Oct. 1620; Gerrit Frederiksz. Druyff aan J. P. Coen, Patani, 4 Nov. 1620. 
gezeild; het kwam daar, zooals reeds gezegd, samen met de Sampson aan.

Op 1 Augustus verscheen voor Patani de Galjas, medebrengende brieven van 3 Juli uit Jacatra. 't Schip had last gekregen, onderweg Jambi aan te doen. $\mathrm{Na}$ aankomst in Patani werd het door Druyff naar Cambodja gezonden ${ }^{1}$ ), een tocht, welke, evenals die van de Vos, van groote beteekenis werd, zooals verderop zal blijken. Op 7 Mei 1621 kwam de Galjas weer in Jacatra. Om in Cambodja het werk voor te bereiden, was reeds op 20 Juli uit Sangora daarheen gezonden 't jacht Klein Hollandia, dat blijkbaar gedurende den winter van 1619 op 1620 in de streken van Patani gebleven was.

Ten slotte moet ik nog melding maken van het schip ${ }^{2}$ ) de Morgenster. In 't laatst van Juli ${ }^{3}$ ) uit Jacatra gezonden met 't jacht Nassau, liet het dit jacht in Jambi achter, en kwam 27 Augustus in Patani aan. Op 4 October bevond het zich voor Sangora. 8 Juli 1621 kwam het uit Patani te Jacatra aan ${ }^{4}$ ).

Ook over de scheepvaart van 't jaar 1621 heerscht veel onzekerheid. In Mei werden, waarschijnlijk uit Jacatra, de schepen ${ }^{5}$ ) Galjas en Tholen naar Patani en Siam gezonden. Het eerste van beide is 13 December van hetzelfde jaar in Batavia teruggekomen. Van de

1) Misschien 16 Aug., vgl. Van Dam II I, p. 348, waar echter 't jaar 1621, dat voor dezen tocht opgegeven wordt, wel op vergissing zal berusten.

2) Hoewel dit in een Copie-res. van G.-G. en Raden van 27 Juli 1620 uitdrukkelijk als schip vermeld wordt, zal er toch wel 't zelfde vaartuig mee bedoeld zijn als 't jacht de Morgenster, dat onder 1619 genoemd is.

3) Op zijn vroegst $27 \mathrm{Juli}$, op zijn laatst 31 .

4) Zie over de schepen in 1620 o.a.: Van Dam II I, p. 348 v.; MacLeod I, p. 500; Gerrit Frederiksz. Druyff aan J. P. Coen te Jacatra, Patani, 8 Mt. 1620; Copiebrief van J. P. Coen aan J. Specx te Firando, in 't schip Nieuw Bantam tusschen Bantam en Jacatra, 3 Mei 1620 (Col. Coen II, p. 703 v.); Copiebrief van J. P. Coen aan Van der Dussen te Jambi, Jacatra, 15 Mei 1620 (Col. Coen II, p. 705 v.); Copiebrief van J. P. Coen aan G. F. Druyff te Patani, Jacatra, 15 Mei 1620 (Col. Coen II, p. 707 v.); Copiebrief van J. P. Coen aan Cornelis Comans te Jambi, Jacatra, 3 Juli 1620 (Col. Coen II, p. 754 v.); idem aan G. F. Druyff te Patani, Jacatra, 3 Juli 1620; Copie-instructie van J. P. Coen voor opperkoopman en schipper van de Galjas, Jacatra, 3 Juli 1620 (Col. Coen II, p. 761); Copie-res. van G.-G. en Raden, fort Jacatra, 27 Juli 1620 (Col. Coen III, p. 625); J. P. Coen c.s. aan beww., Jacatra, 31 Juli 1620 (Col. Coen I, p. 560 v.); Jan van Hasel aan J. P. Coen te Jacatra, Sangora, 4 Oct. 1620; Gerrit Frederiksz. Druyff aan J. P. Coen, Patani, 4 Nov. 1620; Copie-res. van G.-G. en Raden, fort Jacatra, 14 Dec. 1620 (Col. Coen III, p. 672); J. P. Coen c.s. aan beww., Jacatra, 8 Jan. 1621 (Col. Coen I, p. 606 v.); Pieter de Carpentier c.s. aan beww. kamer Amst., Jacatra, 9 Juli 1621.

5) Dat Coen in een brief aan beww. van 20 Dec. 1621 de Galjas een jacht noemt, zal op vergissing berusten. 
Tholen weten we, dat dit schip omstreeks midden Augustus van Siam naar Japan vertrok, maar, deze bestemming blijkbaar niet kunnende bereiken, op 19 September weer koers zette naar Siam, een veroverd schip meevoerende. Van daar is de Tholen naar Sangora en Patani gevaren. Op 4 Maart 1622 is het schip daarna in Batavia aangekomen. In dezen zelfden tijd valt ook de aankomst aldaar van de Eenhoorn. Dit schip had Patani bezocht, waarschijnlijk van Jambi uit, na aldaar een visitateur met brieven voor Patani en Siam te hebben overgenomen uit de naar Jambi gezonden Dolphijn, die 6 Augustus 1621 of kort daarna van Jacatra afgezonden moet zijn. De Eenhoorn is voor de factorij van Patani van groote en onheilspellende beteekenis, daar zij opdracht had, de lichting niet alleen van Patani maar ook van de Noordelijker gelegen Compagnie's kantoren in Achter-Indië voor te bereiden. De geschiedenis van deze opheffing der kantoren zal ons in het laatste hoofdstuk bezig houden. Over den terugkeer van de Eenhoorn in Batavia sprak ik reeds.

Ten slotte moeten ook, volgens verschillende opgaven omtrent in Indië aanwezige schepen, de jachten de Vos en Klein Hollandia in 1621 in de streken van Patani geweest zijn. Ik neem aan, dat beide daar van 1620 af gebleven waren ${ }^{1}$ ).

Wat den handel in Druyff's tijd aangaat, een belangrijk element hierbij, we kunnen zeggen: het belangrijkste element, was ook nu weer de aanvoer der Chineesche artikelen. Druyff blijft zijn volle aandacht aan dit punt besteden; telkens heeft hij weer hoop, op grond van door Chineezen gedane toezeggingen, prachtige ladingen te zullen ontvangen. Maar zijn enthousiasme is niet blind: hij weet maar al te goed, hoe de hebzuchtige autoriteiten van Patani door al te hooge heffingen de Chineesche handelaars kunnen afschrikken. Ook hun

1) Vgl. over de schepen in 1621 o.a.: MacLeod I, p. 500; Pieter de Carpentier c.s. aan beww. kamer Amsterdam, Jacatra, 9 Juli 1621; Rol der Nederl. schepen in Indië, Jacatra, 9 Juli 1621; Copie-instr. van J. P. Coen voor den visitateur Jacques Colijn, Jacatra, 6 Aug. 1621 (Col. Coen III, p. 70 v.); Copiebrieven van J. P. Coen aan Gerrit Frederiksz. Druyff en Cornelis van Nieuwenroode, beide Jacatra, 6 Aug. 1621 (Col. Coen III, p. 72 v.); Lijst der Nederl. schepen in Indië, 15 Nov. 1621; J. P. Coen c.s. aan beww., Batavia, 16 Nov. 1621 (Col. Coen I, p. 641 v.); Lijst der Nederl. schepen in Indië, 19 Dec. 1621 ; J. P. Coen c.s. aan beww., Batavia, 20 Dec. 1621 (Col. Coen I, p. 680 v.); Lijst der Nederl. schepen in Indië, 21 Jan. 1622; J. P. Coen c.s. aan beww., Batavia, 26 Mt. 1622 (Col. Coen I, p. 703 v.); Copiebrief naar Siam aan Jan Mibaise, Batavia, 9 April 1622; Copiebrief naar Patani aan Philips Lucass., Batavia, 1 Mei 1622; Copiebrief naar Sangora aan Jan van Hasel, Batavia, 1 Mei 1622; Copiebrief naar Cambodja aan Jacob Gaermans, Batavia, 1 Mei 1622. 
beloften vertrouwt hij niet. De inlanders hebben, zoo schrijft hij in October 1618, nadrukkelijk beloofd, de Chineesche handelaars als vrienden te zullen behandelen, ,dan vreese den wolff het lecker aes siende sijn oude manier sall aen houden". En ook met het geld op de hand geven was men voorzichtiger geworden. In November van 't zelfde jaar spreekt Druyff in een brief van voorkoop, die met eenige voorname Chineesche kooplieden gemaakt was, zonder dat hun evenwel een voorschot was verleend. Wat er in de jaren 1619, 1620 en 1621 aan Chineesche waren werd aangebracht in Patani en Sangora, was weinig, en bovendien had men dadelijk de Engelschen als felle mededingers, wanneer er iets van belang was in te koopen.

Toch heeft de handel in 't algemeen in Patani in dezen tijd blijkbaar nog het zenden van vrij groote cargasoenen gerechtvaardigd. In 1619 werden 24000 realen in Japansch zilver ${ }^{1}$ ) met de Klein Hollandia naar Patani verzonden, met de Bergerboot en de Morgenster 80000 in Japansch zilver en 40000 in specie, 150 picol sandelhout en nog eenig ander cargasoen, waaronder kruidnagelen. In 1620 bracht de Sampson 97580 realen in contanten en Japansch zilver, alsmede eenige goederen, met de realen samen bedragende f 268 247.5.2, de Zeewolf 16000 realen in specie (waarmee echter zoo noodig ook Jambi moest voorzien worden), de Galjas een zelfde som, en, naar we vernemen, ook nog eenige kleedjes, wat laken, vergulde roers ${ }^{2}$ ) en breede klingen ${ }^{3}$ ). Wederom mocht de Nederlandsche factorijhouder te Jambi, Van der Dussen, zoo noodig een bedrag uit dit schip lichten: inderdaad zijn 12000 realen in Jambi gebleven. De Morgenster ten slotte bracht naar Patani nog 32000 realen in specie. In 1621 brachten de Tholen en de Galjas een kapitaal ter waarde van $\pm \mathrm{f} 115000$. Bij het beoordeelen van de bedrijvigheid in Patani moeten we er rekening mede houden, dat niet alles, wat uit Jacatra daarheen gezonden werd, de factorij ook werkelijk ten goede kwam. Niet alleen dat, zooals we zagen, in Jambi een gedeelte ,afgetapt" kon worden, ook de kantoren, die meer direct onder Patani ressorteerden, Sangora en Siam, moesten er natuurlijk soms hun deel van hebben. En zoo is in Patani toch weer dikwijls geldgebrek. Als er omstreeks medio November 1619 een partij benzoë wordt aangevoerd, grijpt Druyff, om hiervan te kunnen koopen, tot het van ouds

1) Vgl. p. 89 v. Ondanks de daar genoemde bezwaren werd het Japansch zilver $\log$ zoo nu en dan gebruikt.

2) Geweren.

3) Zwaarden. 
beproefde maar niet onbedenkelijke middel : van de koningin worden 10000 realen geleend. Telkens merkt men, dat een zeer belangrijk import-artikel te weinig aangebracht werd, namelijk kleedingstukken, waarvoor in de eerste plaats Koromandel de groote productieplaats van de Compagnie was. Indien men hiervan steeds voldoende voorraad had gehad, om er de begeerde artikelen mee te betalen, in plaats van dit met realen te doen, zou de handel voor Druyff vrij wat voordeeliger geweest zijn. In een brief aan Coen van 8 Maart 1620 noemt hij verschillende soorten kleedjes op, die in Patani met voordeel zouden kunnen aangevoerd worden, waaronder sarassen ${ }^{1}$ ), Bengaalsche cassen ${ }^{2}$ ) en cassa mera's. Later, in een schrijven van 4 November, komt hij nog eens terug op de cassa „mera off roode” cassen, en verlangt hij verder ,"chindeijs" ${ }^{3}$ ) van verschillende kleuren, voornamelijk gele, ,daer zij hier om rasen”.

Ging de handel in den tijd van Druyff's bewind niet altijd even vlot, ook personeelsmoeilijkheden bleven hem niet bespaard. Het jacht Klein Hollandia, dat in 1619 naar Patani was gezonden om een tijdlang in die streken dienst te blijven doen ${ }^{4}$ ), had gebrek aan opvarenden, en zoo moest Druyff bijspringen door vier Hollanders uit de loge van Patani en drie uit die van Sangora af te staan. In beide loges bleven nu slechts vier Hollanders over. Tot overmaat van ramp moest Druyff ook nog zijn onderkoopman missen, die blijkbaar plotseling lijdende werd aan verstandsverbijstering: eerst een ambtenaar, die zijn plicht goed waarnam, zoo schrijft Druyff op 8 Maart 1620 aan Coen, is hij nu ,als een mensch sonder achterdocht en verstant", dien hij, op zijn eigen verzoek, naar Sangora heeft gezonden met de luttele hoop, dat de luchtverandering hem goed zal doen. We zullen hier wel te doen hebben met zekeren Bertram Lubbeeck, die in brieven van Coen en De Carpentier vermeld wordt als onderkoopman

1) Een bekende soort van de Koromandelkust. Het waren gebatikte kleedjes, gebloemde sitsen. Merkwaardig is, dat er onderscheid gemaakt wordt tusschen ,sarasses chera Siam,.... op d' eene zijde geschildert,.... ende.... chera Maleyos, op beyde sijden geschildert" (De laatste soort werd voor Patani gevraagd). Zie mijn proefschrift: De vestiging der Nederlanders aan de kust van Koromandel, Groningen 1911, p. 168.

2) Cassa: neteldoek, zie Itinerario Voyage ofte Schipvaert van Jan Huyghen van Linschoten naar Oost ofte Portugaels Indiën, uitg. Dr. H. Kern (Linschoten-Ver. II), Den Haag 1910, dl. I, p. 66 noot 1.

3) Tjinde of patola is een zijden stof van Voor-Indische herkomst (G. P. Rouffaer en H. H. Juynboll: De Batik-kunst in Nederlandsch-Indië en haar geschiedenis, Utrecht 1914, p. 26.

4) Zie p. 98 . 
tijdens Druyff in Patani, en aldaar overleden is, en waarvan gezegd wordt, dat hij ,hem met vrouwen seer verloopen ende aen de selve veel gelts te cost heeft gehangen", al wordt in beide brieven erkend, dat Druyff het best bevoegd is, over zijn gedrag te oordeelen. Hoe dit zij, Patani had dringend versterking van personeel noodig. In verband hiermee zond Coen in 1620 met de Zeewolf twee onderkooplieden en vier assistenten. Hiervan profiteerde 't kantoor Patani echter maar weinig: van de twee onderkooplieden werd een, Jean Mibaise genaamd, naar Siam gezonden, de andere naar Cambodja; van de assistenten was reeds een in Jambi gelicht, van de andere kregen Sangora, Siam en Patani er ieder een. Geen wonder, dat Druyff in November 1620 Coen verzocht, nog twee assistenten te zenden ${ }^{1}$ ).

Een lastig punt op handelsgebied was voor Druyff de concurrentie, die men in Patani ondervond van de handelaars uit Dabhol, een han-

1) Vgl. over het voorgaande: Copiebrief van Gerrit Frederiksz. Druyff aan beww., Patani, 1 Nov. 1618; Gerrit Frederiksz. Druyff aan beww. kamer Amst., Patani, 26 Mt. 1619; Copiebrief van Cornelis van Nieuwenroode aan Jacques Specx in Firando, Ajudhja, 31 Mei 1619; Copiebrief van J. P. Coen aan Gerrit Frederiksz. Druyff, Jacatra, 2 Juni 1619 (Col. Coen II, p. 555 v.) ; Copieres. van G.-G. en Raden, fort Jacatra, 26 Juni 1619 (Col. Coen III, p. 519 v.); Copiebrief van J. P. Coen aan Jacques Specx te Firando, Jacatra, 2 Juli 1619 (Col. Coen II, p. 570 v.); Copiebrief van J. P. Coen aan G. F. Druyff te Patani, Jacatra, 2 Juli 1619 (Col. Coen II, p. 571 v.); idem aan Cornelis van Nieuwenroode te Ajudhja, Jacatra, 2 Juli 1619 (Col. Coen II, p. 573); Copieinstructie van J. P. Coen voor Hendrik Janssen en raad van de schepen Engel, Bergerboot, Morgenster en Jager, Jacatra, 2 Juli 1619 (Col. Coen II, p. 575 v.); Copie-memorie van J. P. Coen over behoefte aan kleeden en anderzins van de Koromandelkust, Jacatra, 16 Juli 1619 (Col. Coen II, p. 580 v.); J. P. Coen aan beww., Jacatra, 5 Aug. 1619 (Col. Coen I, p. 445 v.); J. P. Coen c.s. aan beww., Jacatra, 22 Jan. 1620 (Col. Coen I, p. 508 v.); Copiebrief van J. P. Coen aan Jacques Specx te Firando, in 't schip Nieuw Bantam, liggende onder Poulo Panjangh, 28 Febr. 1620 (Col. Coen II, p. 652 v.); Gerrit Frederiksz. Druyff aan J. P. Coen te Jacatra, Patani, 8 Mt. 1620; Copie-res. van G.-G. en Raden, in 't schip Nieuw Bantam, liggende in de eilanden van Jacatra nevens den hoek van Ontong Java, 20 April 1620 (Col. Coen III, p. 598); Copiebrief van Pieter de Carpentier ,ter ordonnantie van d' heer generael" aan Gerrit Frederiksz. Druyff te Patani, Jacatra, 21 April 1620 (Col. Coen II, 1. 688 v.); Copie-instructie van Pieter de Carpentier ,ter ordonnantie van d'heer generael" voor de hoofden van 't schip Sampson, Jacatra, 21 April 1620 ; Coen c.s. aan beww., Jacatra, 11 Mei 1620 (Col. Coen I, p. 537 v.); Copiebrief van J. P. Coen aan Van der Dussen te Jambi, Jacatra, 15 Mei 1620 (Col. Coen II, p. 705 v.); idem aan G. F. Druyff te Patani, Jacatra, 15 Mei 1620 (Col. Coen II, p. 707 v.); idem aan Nieuwenroode te Ajudhja, Jacatra, 15 Mei 1620 (Col. Coen II, p. 711 v.); idem aan Van Hasel te Sangora, Jacatra, 15 Mei 1620 (Col. Coen II, p. 713); idem aan Van der Dussen te Jambi, Jacatra, 3 Juli 1620 (Col. Coen II, p. 755 v.); idem aan G. F. Druyff 
delsstad, iets ten Noorden van Goa gelegen, en die onder invloed van de Portugeezen stond. Deze lieden brachten hun goederen naar Tenasserim en Queda ${ }^{1}$ ), vanwaar ze dan verder naar Patani, Siam en omliggende streken werden vervoerd. In Juli 1620 werd te Jacatra dan ook besloten, dat men de vaart der Dabholders zooveel mogelijk zou verhinderen ${ }^{2}$ ).

Ernstiger nog was het gevoel van onveiligheid, dat in de jaren 1619,1620 en 1621 heerschte wegens het voortdurende gevaar van een aanval der veroveringszuchtige Atjehers. Vooral toen dezen Queda hadden veroverd, aan de Westkust van 't schiereiland van Malakka tegenover Patani liggende, was bij de inwoners der laatste plaats de vrees groot. Ze hadden reeds partij gekozen door het zenden van 200 man als helpers voor die van Queda, en gingen ook hun eigen stad versterken met veel oorlogspreparatiën, als het gieten van geschut en het maken van twee groote schansen buiten de stad. Druyff heeft geen vertrouwen in deze ostentatieve krijgshaftigheid. „Godt geve haer”, zoo meesmuilt hij, ,,soodanige crychsmansherten als well groote buijcken en dicke halsen hebben". Volgens zijn meening zullen ze bij werkelijk naderend gevaar - dat hij trouwens niet waarschijnlijk acht - wel 't hazenpad kiezen naar de bosschen. Aldus uit hij zich in Maart 1619. Een aanval heeft toen blijkbaar niet plaats gevonden. Maar de Pataniërs bleven op hun hoede. In 1620 trouwt de zustersdochter van de koningin van Patani, erfgename van de kroon, met den koning van Bordelon, oudsten zoon van den koning van Ligor, wel in de eerste plaats opdat men aldus gezamenlijk beter tegen het Atjehsche gevaar bestand zal zijn. En Coen schrijft in Mei 1620 aan Druyff, dat men in Patani voorzichtig moet zijn: hij heeft ge-

te Patani, Jacatra, 3 Juli 1620 ; J. P. Coen c.s. aan beww., Jacatra, 31 Juli 1620 (Col. Coen I, p. 560 v.); Pieter de Carpentier aan beww., fort Jacatra, 31 Juli 1620; Jan van Hasel aan J. P. Coen te Jacatra, Sangora, 4 Oct. 1620; J. P. Coen c.s. aan beww., Jacatra, 26 Oct. 1620 (Col. Coen I, p. 585 v.); Gerrit Frederiksz. Druyff aan J. P. Coen, Patani, 4 Nov. 1620; J. P. Coen c.s. aan beww., Jacatra, 8 Jan. 1621 (Col. Coen I, p. 606 v.); Pieter de Carpentier c.s. aan beww. kamer Amst., Jacatra, 9 Juli 1621; Verklaring van Gerrit Frederiksz. Druyff voor leden uit den dagelijkschen raad van 't fort Batavia, fort Batavia, 8 Febr. 1622; Copiebrief van Coen aan beww. te Amst. en Middelburg, fort Batavia, 29 Mt. 1622 (Col. Coen IV, p. 722 v.); Pieter de Carpentier aan beww., Batavia 29 Mt. 1622; Copiebrief naar Siam aan Jan Mibaise, Batavia, 9 April 1622; idem aan idem, Batavia, 1 Mei 1622.

1) Beide op het schiereiland van Malakka.

2) Vgl. over de Dabholders : Copie-res. van G.-G. en Raden, fort Jacatra, 18 Juli 1620 (Col. Coen III, p. 619 v.); J. P. Coen c.s. aan beww., Batavia, 21 Jan. 1622 (Col. Coen I, p. 688 v.). 
hoord, dat de vloot van Atjeh weer gereed gemaakt is, weliswaar naar het zeggen tegen Malakka, maar 't kon wel eens tegen Patani bedoeld zijn. Druyff moet, indien de loges in Patani en Sangora, zooals Coen vreest, geen genoegzame veiligheid bieden, niet te veel geld in deze beide kantoren laten!

Dat een dergelijke langdurige angststemming niet bevorderlijk was voor den handel, spreekt vanzelf ${ }^{1}$ ).

Sangora bleef voor den handel in zekeren zin betere mogelijkheden bieden dan Patani, en wel door de grootere vrijheid, waarmee de inlanders dezen handel toelieten. Mochten in 1618 nog klachten gerezen zijn over afpersing van de met hun jonken aankomende Chineezen ${ }^{2}$ ), in een brief, gedateerd 8 Maart 1620, bericht Druyff, dat de peper en verder alle Chineesche waren, die in Sangora ontscheept worden, vrij zijn van tol- en waaggeld; de onkosten in Patani vallen onvergelijkelijk veel hooger. Volkomen zeker tegenover vorstelijke willekeur voelt men zich echter nog niet, want op 4 October 1620 schrijft Jan van Hasel $^{3}$ ), in dien tijd hoofd van ons kantoor in Sangora, aan Coen, dat de koning van Ligor oud en ziekelijk is, zoodat de mandarijnen met de vreemdelingen ,haere personagie spelen", zooals in 1620 zeer te merken is geweest. Nu heeft de Compagnie, zoover ik weet, nooit een bepaald kantoor in Ligor gehad, maar handel werd daar door de onzen toch wel gedreven. En evenals Hendrik Janssen, zoo raadt nu ook Druyff, er toch voor te zorgen, eenige kleinigheden te zenden als schenkage voor de koningen van Ligor en „Bordelong oft Sangora”, waardoor men licht van hun vriendschap verzekerd kan blijven.

In de versterking van onze loge te Sangora, waarover ik reeds boven gesproken heb ${ }^{4}$ ) was inmiddels voortgang gekomen. Er was een steenen ,godong" ${ }^{5}$ ) gebouwd, die daarna nog aan weerszijden

1) Vgl. over de Atjehers: Tiele Eur. 5 II, p. 306 ; J. P. Coen c.s. aan beww., in 't schip de Oude Zon, liggende voor Mandalique omtrent 3 mijlen bij Oosten Japara, 14 Jan. 1619 (Col. Coen I, p. 416 v.); Gerrit Frederiksz. Druyff aan beww. kamer Amst., Patani, 26 Mt. 1619; Copiebrief van Cornelis van Nieuwenroode aan Jacques Specx in Firando, Ajudhja, 31 Mei 1619; Copiehrief van J. P. Coen aan G. F. Druyff te Patani, Jacatra, 15 Mei 1620 (Col. Coen II, p. 707 v.); Jan van Hasel aan J. P. Coen te Jacatra, Sangora, 4 Oct. 1620; Gerrit Frederiksz. Druyff aan J. P. Coen, Patani, 4 Nov. 1620; J. P. Coen c.s. aan beww., Jacatra, 8 Jan. 1621 (Col. Coen I, p. 606 v.).

2) Zie p. 86.

3) Vgl. p. 94 .

4) Pag. 85.

5) Een pakhuis. Zie over dit woord: Yule and Burnell: Hobson-Jobson, New Edition, I.ondon 1903, s.v. godown. 
met een rondeeltje was versterkt, alles volgens de plannen van Hendrik Janssen en den raad van Patani. Wanneer men nu maar niet te weinig Nederlandsche verdedigers had, bood deze versterking een welkome verdediging tegen de Portugeezen, des te noodiger, daar Sangora, ,een vlecxken van weijnich inwoonders”, niet veel binnenlandsche hulp zou kunnen bieden. Verder wist men nooit, hoe de nieuwe versterking nog eens tegen de Engelschen te pas kon komen! En evenals deze laatsten bij onze eerste vestiging in Sangora dadelijk getracht hadden, onze monopolistische positie aldaar te ondermijnen ${ }^{1}$ ), waren ze, toen we de loge aldaar op de bovenvermelde wijze versterkt hadden, niet gezind, dit rustig aan te zien. Als hun woordvoerder trad Adam Denton op, wiens naam op zich zelf wegens zijn rol bij het drama van de $Z$ warte Leeuw in 1618 op de Nederlanders reeds werkte als een roode lap. $\mathrm{Hij}$ maakte in Ligor ${ }^{2}$ ) den koning en eenige mandarijnen opmerkzaam op het groote gevaar, dat de Nederlandsche versterking meebracht: Sangora zou, als het zoo doorging, een tweede Jacatra worden, en het inlandsche gezag over deze plaats totaal vernietigd worden. Druyff zag echter tijdig het gevaar. Met den koopman van Sangora bracht ook hij een bezoek aan den vorst, en het gelukte hem, de intrigues van Adam Denton te verijdelen: de rondeelen mochten blijven bestaan en 't geschut in de godong mocht gehandhaafd blijven. Wel had deze stap ongeveer honderd realen aan schenkages en andere uitgaven gekost, maar deze prijs was niet te hoog $\left.{ }^{3}\right)$.

In Siam werd, terwijl Druyff Patani bestuurde, onze factorij door den opperkoopman Cornelis van Nieuwenroode geregeerd ${ }^{4}$ ). Druyff had met dit kantoor minder direct te maken dan met Sangora, dat met Patani een soort twee-eenheid vormde. En hij scheen het verband nog losser te willen maken. Naar aanleiding van klachten over schaarschheid van kapitaal, geuit door Van Nieuwenroode, maakt hij in een brief aan bewindhebbers van Amsterdam de opmerking, dat eigenlijk 't kantoor in Hirado de zorg van de kapitaalsvoorziening van Siam op zich behoorde te nemen, daar omgekeerd de goederen

1) Zie p. 69 .

2) Ik kan niet nagaan, of hier sprake is van den eigenlijken koning van Ligor, die dan den vorst van Bordelon en Sangora zou moeten beïnvloeden, of dat deze laatste zich toen toevallig in Ligor bevond.

3) Vg1. omtrent Sangora: Gerrit Frederiksz. Druyff aan J. P. Coen te Jacatra, Patani, 8 Mt. 1620 ; Jan van Hasel aan J. P. Coen te Jacatra, Sangora, 4 Oct. 1620 ; Gerrit Frederiksz. Druyff aan J. P. Coen, Patani, 4 Nov. 1620.

4) Vgl. p. 94 . 
uit Siam toch ook voor Japan bestemd waren, een redeneering, waar stellig iets voor te zeggen valt. In 't laatst van 1620 schreef Druyff aan Coen, mondeling te hebben vernomen, dat Van Nieuwenroode zijn ontslag als factor in Ajudhja verzocht. Hij beval als opvolger aan zekeren Willem Cunningen ${ }^{1}$ ), onderkoopman in Siam, dien hij zeer hoog schatte, al kon hij dan, zoo had Druyff vernomen, slecht met zijn chef overweg. Druyff veronderstelde echter, toen hij Cunningen aanbeval, de mogelijkheid, dat deze zich zou verbinden, in Cambodja Compagnie's belangen waar te nemen. Inderdaad heeft Cunningen daarheen een reis gedaan; hij kwam vandaar op 3 November 1620, nog vóór Druyff zijn brief aan Coen had voltooid, met 't jacht de Vos in Patani aan ${ }^{2}$ ). Spoedig zou het blijken, dat er voor Van Nieuwenroode in Siam geen opvolger noodig zou zijn ${ }^{3}$ ).

Merkwaardiger dan het vermelde omtrent Sangora en Siam is het feit, dat tijdens het bestuur van Gerrit Frederiksz. Druyff van Patani nog ter elfder ure, in 1620, de stichting van een nieuw kantoor uitging, namelijk van dat in Cambodja. Deze stichting berustte, zooals we weten, allerminst op een plotselingen inval: reeds in 1609, onder 't bewind van Victor Sprinckel, bestond het plan, een kantoor in Cambodja te stichten, waar dan hertevellen en roggevellen zouden ingekocht kunnen worden voor den handel op Japan, die met den tocht van de Roode Leeuw met Pijlen en de Griffioen zoo hoopvol begonnen was. Kapitaalgebrek had toen, gelijk wij zagen, de stichting van een factorij in Cambodja verhinderd ${ }^{4}$ ). En verder had men getracht, zich met den lossen handel op dit land zoo goed mogelijk te behelpen ${ }^{5}$ ).

Wanneer nu in 1620 weer opnieuw sprake was van het stichten

1) We treffen dezen reeds in 1615 als Compagnie's dienaar in de buurt van Patani aan - vgl. Copiebrief van J. P. Coen an Hendrik Janssen, Bantam, 10 Juni 1615 (Col. Coen II, p. 10 v.) - Colenbrander (Coen II, p. 789) wijst op de mogelijkheid, dat de naam (welke inderdaad Engelsch aandoet) een verbastering is van Cunningham.

2) Vgl. over Siam: Gerrit Ferederiksz. Druyff aan beww. kamer Amst., Patani, 26 Mt. 1619; idem aan J. P. Coen, Patani, 4 Nov. 1620.

3) Zie hoofdstuk VIII.

4) Zie p. 49 v.

5) Belangrijk en ook noodlottig was het jaar 1616 geweest. Er werden toen uit Patani twee Nederlanders ,ende eenen swart” naar Cambodja gezonden. $\mathrm{Ze}$ dreven daar een voordeeligen handel, maar werden bij 't afvaren van de rivier (de Me-kong) door Portugeezen overvallen, die de Hollanders gevangen namen, en wegvoerden. De koning van Cambodja deed een vruchtelooze poging, met opoffering van meer dan 30 menschen, de gevangenen te ontzetten. De Compagnie leed hierbij volgens opgave van Hendrik Janssen 
van een kantoor, was niet meer uitsluitend het belang van den Japanschen handel de beweegreden hiertoe; er kwam meer bij. Ten eerste was er in die dagen om bijzondere redenen, waarop ik nader terugkom, schaarschte aan rijst voor de Compagnie, en hoopte men dit artikel in groote quantiteiten uit Cambodja,te betrekken. Maar verder werd ook vooral nadruk gelegd op de benzoë, waar het kantoor van Jacatra zeer naar vroeg; in Cambodja, zoo had men begrepen, zou de benzoë veel goedkooper te verkrijgen zijn dan in Patani of Siam. En daarmee is nog niet alles gezegd: arak, boter, varkensvleesch, gezouten in potten, hoopte men er eveneens vandaan te krijgen.

De koning van Cambodja, die, zooals Druyff schrijft, ,grootelijcx onse kennisse is soeckende", zou van zijn kant natuurlijk de handelsvoorwaarden voor de Compagnie zoo voordeelig mogelijk maken.

Drie schepen zijn in 1620 uit Patani of Sangora erheen vertrokken; en wel als eerste het jacht de Vos, dat in Februari uit Siam voor Patani verschenen was ${ }^{1}$ ). Het moest onderweg naar Cambodja den zooeven genoemden Willem Cunningen lichten in Siam, die dan als opperhoofd mee naar Cambodja zou gaan, aangezien hij verstand had van de handelsgelegenheid aldaar.

20 Juli vertrok daarop, gelijk reeds is opgemerkt ${ }^{2}$ ), het jacht Klein Hollandia uit Sangora naar Cambodja. Het nam 4000 realen mee, om daarmee het voorbereidend werk te ondernemen voor een grooter schip, dat later komen zou. Dit is de Galjas geweest, die 1 Augustus in Patani was aangekomen ${ }^{3}$ ). Over wat er met de Klein Hollandia op haar tocht naar Cambodja is gebeurd, is mij verder niets bekend. Coen meldt in een schrijven van 8 Januari 1621 aan bewindhebbers, dat er gevreesd wordt, dat het jacht is verongelukt. De Vos en de Galjas hebben echter beide haar bestemming bereikt en zijn nog gelijk-

een schade aan kapitaal van \pm 4000 gulden. In Juni 1617 werd de onderkoopman Jan Janssen Hoochlandt uit Patani naar Cambodja gezonden met een lading kleedjes. We weten, dat hij een goed retour verkreeg, en dat de koning zich weer even welwillend betoonde als 't vorige jaar, en alle medewerking tegen de Portugeezen toezegde. Vgl. Lett. Rec. V, $\mathrm{n}^{\circ} 478$; Copieress. genomen te Patani door de raadspersonen van 't kantoor en de schepen Zwarte Leeuw en Galjas, Patani, 26 Mei 1617; Copiebrief van Hendrik Janssen aan J. P. Coen te Bantam, Patani, 25 Oct. 1617; J. P. Coen aan beww., Bantam, 18 Dec. 1617 (Col. Coen I, p. 290 v.); Gerrit Frederiksz. Druyff aan beww. kamer Amst., Patani, 26 Mt. 1619. Zie verder ook p. 84.

1) Zie p. 99.

2) Zie p. 100 .

3) Zie p. 100 . 
tijdig in Cambodja geweest. De Galjas had als opperkoopman aan boord Jacob Gaermans en verder een der onderkooplieden, die met de Zeewolf in Patani waren gekomen ${ }^{1}$ ). Druyff had er zorg voor gedragen, dat de Galjas een goede som aan contanten had meegekregen. Het vaartuig had groote moeite, de rivier de Me-kong op te komen naar Pnom-Penh, de koninklijke residentie. Veel van de bijzonderheden omtrent de verrichtingen en het succes der beide schepen in Cambodja ontgaat ons bij gebrek aan gegevens. We weten, dat de Vos bij terugkomst in Patani op 3 November $1620^{2}$ ) 548 picol benzoë meebracht, volgens Coen wel $100 \%$ goedkooper (!) ingekocht dan in Patani en Siam, verder nog was en andere waren. De Galjas, waarvan de handel geschaad was door de late aankomst en den moeilijken tocht rivieropwaarts, bracht op 7 Mei $1621^{3}$ ) te Jacatra uit Cambodja 158 picol benzoë aan, verder 90 lasten rijst, boonen, arak en andere zaken. Coen, volkomen overtuigd van de gunstige toekomst van den benzoëhandel in Cambodja, gaf kort daarop last aan de Raden van Indië, uitsluitend uit die streek dit product te koopen, en niet langer in Patani of Siam.

Het belangrijkste van dit dubbele bezoek aan Cambodja was echter nog het stichten van een Nederlandsche factorij. Van den koning ondervond men de meest mogelijke medewerking; het kantoor is, naar het mij schijnt, gesticht in Lauweck (in de buurt van PnomPenh), waar later wederom een factorij is opgericht ${ }^{4}$ ). Men kon $n u$ van nabij handel drijven met de "Lauwen” en de „Lanhangers” ${ }^{5}$ ) uit het binnenland, welke voordien hun producten wel naar Siam plachten te brengen, maar dit nu niet meer behoefden te doen. Men vertrouwde, den handel in benzoë, cardamon, goud en andere waren te zullen monopoliseeren.

Niet eenvoudig te beantwoorden is de vraag omtrent de bezetting van onze eerste loge in Cambodja. Er is sprake van geweest, dat

1) Zie p. 104. Hebben we hier misschien te doen met den straks te noemen Pieter Seijs?

2) Zie p. 99.

3) Zie p. 100 .

4) Zie Dr. H. P. N. Muller: De O. I. C. in Cambodja en Laos, werken Linschoten-Vereeniging $\mathrm{n}^{\circ}$ XIII, Den Haag 1917, p. XLIII. De onderstelling, op p. XLI geuit, dat de eerste loge aan zee gelegen moet hebben, deel ik niet. Het door Muller aangehaalde citaat ,de plaetse in de bocht" slaat op de handelskantoren in de buurt van Patani in den ruimsten zin. Ook Ajudhja, dat toch stellig niet aan zee lag, hoorde hieronder.

5) De inwoners van Laos en van Langsjiang. 
Cunningen ${ }^{1}$ ) er zou blijven; de koning verzette zich echter hiertegen, zoo hooren we, daar hij uit Siam kwam, zonder eenige machtiging van den gouverneur-generaal. Het bezwaar tegen zijn herkomst uit Siam doet zonderling aan. Wellicht staat het in verband met de politieke spanning, die tusschen de beide staten bestond, daar de vorst van Siam rechten op Cambodja beweerde te hebben. Cunningen is dus met de Vos weer naar Patani gevaren ${ }^{2}$ ). De meeste kans, als onze eerste factor in Cambodja te moeten gelden, heeft zeker Pieter Seijs ${ }^{3}$ ). Deze, waarvan ik niet kan nagaan, of hij met de Vos of met de Galjas was gekomen, schijnt slechts een voorloopige aanstelling gekregen te hebben. Hij was er gelaten bij gebrek aan beter, zoo schrijft 4 November 1620 Druyff, die hen totaal onbekwaam noemt. Of ook Gaermans tenslotte in Cambodja gebleven is? De bedoeling was dit niet: uit genoemden brief van Druyff, welke aan Coen was gericht, blijkt, dat Gaermans bestemd was, naar dezen laatsten terug te keeren. Mogelijk echter is hij in Cambodja gebleven ${ }^{4}$ ). Hoe dit zij, zeker is het, dat op het nieuwe kantoor aanvankelijk groote verwachtingen gebouwd werden ${ }^{5}$ ).

1) MacLeod I, p. 500, noemt hem Willem Everingen.

2) Zie p. 108.

3) Zie p. 110 , noot 1 .

4) Op 1 Mei 1622 wordt uit Batavia een brief aan hem in Cambodja geschreven, waaruit duidelijk wordt, dat 2 April 1622 het jacht de Vos vandaar cver Patani te Batavia is aangekomen, een brief van Gaermans medebrengende, waaruit blijkt, dat de koning hem geen licentie heeft willen geven, te vertrekken. De vraag blijft natuurlijk, of Gaermans tusschentijds uit Cambodja weg geweest is.

5) Vgl. over onze vestiging in Cambodja: Van Dam II I, p. 348 v.; Muller : O. I. C. in Cambodja en Laos, p. XXXVI, XLI v.; MacLeod I, p. 500; Copiebrief van J. P. Coen aan Gerrit Frederiksz. Druyff, Jacatra, 2 Juni 1619 (Col. Coen II, p. 555 v.); Gerrit Frederiksz. Druyff aan J. P. Coen te Jacatra, Patani, 2 Mt. 1620; Copiebrief van Pieter de Carpentier „ter ordonnantie van d' heer generael" aan Gerrit Frederiksz. Druyff te Patani, Jacatra, 21 April 1620 (Col. Coen II, p. 688 v.) ; Copiebrief van J. P. Coen aan G. F. Druyff te Patani, Jacatra, 23 Juni 1620 (Col. Coen II, p. 745 v.); idem van denzelfde, Jacatra, 3 Juli 1620; Copie-instructie van J. P. Coen voor opperkoopman en schipper, varende met de Galjas naar Jambi enz. (Col. Coen II, p. 761); Jan van Hasel aan J. P. Coen te Jacatra, Sangora, 4 Oct. 1620; J. P. Coen c.s. aan beww., Jacatra, 8 Jan. 1621 (Col. Coen I, p. 606 v.); Copie-memorie van J. P. Coen voor Pieter de Carpentier en Jacob Dedel te Jacatra, Jacatra, 12 Jan. 1621 (Col. Coen III, p. 5 v.); Copiebrief van J. P. Coen aan Raden van Indië te Jacatra, Amboyna, 29 Mei 1621 (Col. Coen III, p. 40 v.); Pieter de Carpentier c.s. aan beww. kamer Amst., Jacatra, 9 Juli 1621; Translaat van de missive, door den koning van Siam aan G.-G. geschreven, Ajudhja, 5 Jan. 1622; Copie-brief naar Cambodja aan Jacob Gaermans, Bataviá, 1 Mei 1622. 
Een deel van het behaalde succes was stellig te danken aan Gerrit Frederiksz. Druyff, die nu tevens het gebied van zijn werkzaamheden weer vergroot zag, en, wat zijn positie ten aanzien van den Compagnie's handel betreft, als een van de belangrijke figuren mocht gelden. Dat hij in alle opzichten werkte tot tevredenheid der heeren in Jacatra, kan evenwel niet gezegd worden. Coen heeft grieven tegen zijn beleid gehad, welke hij ook met de hem eigene, dikwijls pijnlijk aandoende duidelijkheid tegen hem geuit heeft. We hebben Druyff gekenschetst als een ijverig en energiek man, blakend van ongeduld, om, na het vertrek van Hendrik Janssen, even schitterende cargasoenen naar het Zuiden te kunnen zenden, als er in 1618 een met de $Z$ warte Leeuw afgezonden was. De fouten, door Druyff begaan, zijn min of meer „les défauts de ses qualités” geweest. Al zijn streven was blijkbaar gericht op veel inkoopen, om door groote ladingen het belang van Patani en zijn eigen competentie te kunnen toonen. Maar dit heeft hem, volgens Coen's verwijten, verleid tot te duur inkoopen. $\mathrm{Nu}$ moest natuurlijk door 't centrale bestuur menig overijld factorijbeheerder ook in andere deelen van Indië in dit opzicht wel eens worden terechtgewezen, maar Coen's verwijten zijn zoo menigvuldig en zoo kras gesteld, dat we bij Druyff een zekere lichtzinnigheid bij 't inkoopen toch wel als eigenschap mogen beschouwen. De Chineesche waren, in 1619 gezonden, waren, schrijft Coen, van minderwaardige kwaliteit geweest en te duur ingekocht. Ook de benzoë, die Druyff in 1619 kocht met van de koningin geleend geld ${ }^{1}$ ), 350 picol in totaal, vindt Coen te hoog in prijs. Bijzonder onaangenaam voor Druyff was een brief van Coen, den eersten Augustus 1620 door het schip de Galjas in Patani aangebracht. Sommige goederen, lezen we hierin, waren door Druyff wel 50, ja $100 \%$ te duur ingekocht. En bij de beschuldiging over onbezonnen inkoopen blijft het niet: ten voordeele van het eigen kantoor, zoo schrijft Coen, had Druyff dat van Siam verwaarloosd door het niet van voldoende kapitaal te voorzien, terwijl dat toch in zijn macht geweest was. Aan het einde van tal van verwijten beveelt Coen hem, in 't vervolg beter zorg te dragen voor het goed besteden van 't kapitaal der Compagnie, ,opdat selffs niet genootsaeckt worden, daerinne te versien".

Druyff bleef op de verwijten van Coen het antwoord niet schuldig: mocht in 1619 een hoeveelheid zijde wat duur ingekocht zijn, dan kwam dit door de moeilijkheden, die onzen handel door de concur-

1) Zie p. 102 v. 
reerende Engelschen bereid werden. Dat in 1619 er in Patani 50000 realen in zilver over zouden geweest zijn om naar Siam te zenden voor den handel aldaar, zooals Coen had geschreven, was volgens Druyff onjuist: Coen moest bedenken, dat niet alleen in Patani maar ook in Sangora, Bordelon en Ligor geld moest zijn voor den handel met de Chineezen en voor het opkoopen van peper, voordat de Chineezen hiermee konden gaan strijken; ook moest men er voor zorgen, den Engelschen bij 't inkoopen te vlug af te zijn. En verder: Druyff kon niet weten, wat er in Siam noodig zou zijn: Nieuwenroode, zoo schrijft hij, scheen zich er op toe te leggen, hem te negeeren; nooit had hij hem er van in kennis gesteld, wat hij voor den handel in Siam noodig had. Maar Coen liet zich niet overtuigen. Hij bleef bij zijn meening: „Het schijnt”, zoo schreef hij in Januari 1621 aan bewindhebbers, ,dat in Patany niet seer gelet wort, hoe het gaet (met) coopen, even alsoff het wel waer, als het gelt maer besteet zy". En nog na zijn ambtstijd in Patani heeft Druyff zich te dezer zake te Batavia te verantwoorden: voor eenige leden uit den dagelijkschen raad van 't fort aldaar legt hij in Februari 1622 ten verzoeke van Coen ,by ware woorden in plaetse van solemnelen eede" 1 ) een verklaring af, waarbij hij zich rechtvaardigt over het tot hoogen prijs inkoopen van benzoë en peper in 't jaar 1621; handelsnijd en dwarsdrijverij van de Engelschen, zoo verklaart hij, waren ook hier wederom de oorzaak.

De bitse aanmerkingen van Coen, de trotsche houding van Van Nieuwenroode, Druyff heeft er stellig onder geleden. Maar het waren niet de eenige oorzaken, die hem den lust in zijn werk benamen: evenals indertijd Hendrik Janssen, zoo ondervond ook hij den nadeeligen invloed van het leven in de tropen: in November 1620 schrijft hij, een langen tijd ziek geweest te zijn; wel is hij dan genezende, ,,dan noch al weeckelijck, aen een gestadelijcken loop gaende, worde gantsch onder de voet gehouden”. En ,sieckelijck gaende, heeft ${ }^{2}$ ) een mensch lust noch smaeckelijcheijt in al wat hij ter hand neempt ${ }^{3}$ ).

1) Druyff was dus blijkbaar doopsgezind.

2) Er staat: geeft.

3) Vgl. over 't voorgaande: Copiebrief van J. P. Coen aan G. F. Druyff te Patani, Jacatra, 15 Mei 1620 (Col. Coen II, p. 707 v.); Copiebrief van J. P. Coen aan Nieuwenroode te Ajudhja, Jacatra, 15 Mei 1620 (Col. Coen II, p. 711 v.); idem aan G. P. Druyff te Patani, Jacatra, 23 Juni 1620 (Col. Coen II, p. 745 v.); idem aan denzelfde, Jacatra, 3 Juli 1620; J. P. Coen c.s. aan beww., Jacatra, 31 Juli 1620 (Col. Coen I, p. 560 v.); Gerrit Fredericksz.

Verh. dl. I. 
Toch zou Druyff allicht nog meer „smaeckelijcheijt” in zijn werk gehouden hebben, en de eerzucht hebben gehad, zijn reputatie als koopman bij Coen te verbeteren, als de uiterlijke omstandigheden niet zoo buitengewoon ongunstig voor hem waren geweest. Alles liep tegen en scheen tegen hem samen te spannen. Het handeldrijven ging in Patani hoe langer hoe stugger door de steeds grootere moeilijkheden, die men van het Portugeesche gevaar ondervond, en de concurrentie der Engelschen.

Wat de Portugeezen betreft, men moet niet denken, dat omstreeks 1620 deze onze voorgangers in den Archipel, de „kale vinken”, de „specken”, een overwonnen gevaar vormden, en onzen voorouders nog slechts tot medelijdenden spot strekten. Dit mocht in zekeren zin waar zijn voor Java, in Patani had men een geheel ander inzicht: Malakka, nog steeds een respectabel Portugeesch machtspunt, lag hier veel te dicht bij. En zoo lang nu maar de inlanders op onze hand waren, en bereid om, al was 't dan ook nog zoo slap, onze zaak tegen de Portugeezen te ondersteunen, ging het nog.

Maar deze toestand bleef niet bestaan: de regeering van Patani sloeg om, ook al in verband met de politiek van den koning van Siam. Deze had in November 1616 twee gezanten naar Goa gezonden en vandaar naar Portugal, ten einde een verbond tot stand te brengen. Hierna werd ook Patani den Portugeezen gunstig gezind en konden ze zich daar in grooten getale vestigen. In het laatst van 1618 merkten de Hollanders in Patani de voor hen zoo nadeelige verandering: de Portugeezen traden niet alleen als onbestrijdbare concurrenten op in den kleedjesaanvoer, maar maakten ook dagelijks met hun kleine, snelvarende scheepjes de kust bij Patani, Sangora en Ligor voor de onzen onveilig. We spraken reeds over de zending van het jacht Klein Hollandia als afweermiddel in dit verband ${ }^{1}$ ). Hierdoor werd onze positie aan de bocht ontegenzeggelijk versterkt: Van Hasel betuigt op 4 October 1620 in een brief uit Sangora aan Coen zijn

Druyff aan J. P. Coen, Patani, 4 Nov. 1620; J. P. Coen aan beww., Jacatra, 8 Jan. 1621 (Col. Coen I, p. 606 v.); Copie-memorie van J. P. Coen voor Pieter de Carpentier en Jacob Dedel, Jacatra, 12 Jan. 1621 (Col. Coen III, p. 5 v.); Copie-instructie van J. P. Coen voor Jacques Colijn Jansz., gedestineerd naar de kantoren Patani etc., Jacatra, 6 Aug. 1621 (Col. Coen III, p. 70 v.); Copiebrief van J. P. Coen aan Soury te Masulipatam, Jacatra, 12 Aug. 1621 (Col. Coen III, p. 73 v.) ; J. P. Coen c.s. aan beww., Batavia 20 Dec. 1621 (Col. Coen I, p. 680 v.); Verklaring van Gerrit Frederiksz. Druyff voor eenige leden uit den dagelijkschen raad van 't fort Batavia, fort Batavia, 8 Febr. 1622.

1) Zie p. 98. 
tevredenheid over de ingetreden gunstige verandering. Maar de positie van de koningin van Patani werd door deze vijandelijkheden vlak bij haar kust wel zeer moeilijk. Ze zag geen kans, met beide strijdende partijen een goede verstandhouding te bewaren, en zond daarom in 1620 een gezant met een zilveren beteldoos als vereering aan Coen, om hem er op te wijzen, hoe de Pataniërs indertijd terwille van de Hollanders met de Portugeezen in vijandschap waren geraakt; voor de veiligheid van haar eigen volk had ze nu met die van Malakka vrede moeten sluiten. $Z$ e verzocht met aandrang, geen Portugeesche schepen bij haar kust lastig te vallen, en ook aan Patanische jonken, die op Malakka en de Molukken handel met de Portugeezen wilden drijven, geen zwarigheden in den weg te leggen. Deze gezant, die met eenige vertraging te Jacatra was aangekomen, werd in 1621 met den toen naar Patani vertrekkenden visitateur ${ }^{1}$ ) teruggezonden met een besliste weigering. Coen verklaarde, dat het belang van de Compagnie meebracht, den strijd met de Portugeezen onverzwakt door te zetten, waar men hen ook aantrof. Verder werd een waarschuwing tot de koningin gericht, geen handel door Pataniërs meer met Portugeezen in Malakka of de Molukken te laten doen, daar hun schepen niet met rust zouden worden gelaten. Dat de jonken van haar onderdanen daarentegen in Jacatra welkom zouden zijn, kon voor de koningin slechts tot schrale troost strekken. Het meezenden van schenkages voor de koningin en eenige van haar voornaamste mandarijnen moest aantoonen, dat men voorloopig de goede betrekkingen nog niet wenschte te verbreken.

Van de Engelschen ondervond Druyff ook steeds meer last, en wel in verband met het belangrijke verdrag, dat tusschen de Compagnieën van beide landen in 1619 was tot stand gekomen. 27 Maart 1620 was de tijding hiervan door het Engelsche schip de Bull in Jacatra gebracht, vanwaar de overeenkomst, gelijk we reeds zagen, door het schip de Sampson in Mei daaraanvolgende in Patani was gebracht ${ }^{2}$ ). Vrede heeft zij echter, zooals men zal weten, in Indië allerminst gebracht; de „Ambonsche moord”, in 1623, zou hiervan getuigenis geven. Men kent de verontwaardigde uitingen van Coen tegenover zijn meesters: een pretentieuse concurrent, zoo was zijn beschouwing, dien men wegens zijn geringere kapitaalskracht door eigen kracht toch wel uit Indië gewerkt zou hebben, werd nu als gelijkwaardig naast ons geplaatst op terreinen, die, om zoo te zeggen,

1) Zie p. 101.

2) Zie p. 99. 
door de onzen met moeite waren ontgonnen. Wat dit in Patani voor gevolgen heeft gehad, daarover zullen we beneden nog moeten spreken. Genoeg zij het, dat ook Gerrit Frederiksz. Druyff zich bitter beklaagde over de aanmatiging, ook in deze plaats door de Engelschen tengevolge van het tractaat aan den dag gelegd.

Maar de ergste bedreiging van ons kantoor in Patani kwam van andere zijde. Tijdens Druyff's bewind speelden zich in Indië critieke gebeurtenissen af. De Compagnie trad, na veel aarzeling en onzekerheid, in een nieuw stadium van haar ontwikkeling. Was de wilde vaart der concurreerende ondernemingen in 1602 tot consolidatie gekomen door de stichting van de Vereenigde Compagnie, had in 1610 het beleid daarvan in Indië zijn stabiliseering gekregen door het aanstellen van een gouverneur-generaal, in 1619 werd een nadere versteviging van den handel bereikt: op 30 Mei van dit jaar viel Jacatra definitief in handen van Coen, en werd de inlandsche kota in de asch gelegd. Hiermee was de laatste mijlpaal bereikt: de twijfel omtrent de plaats van het algemeen rendez-vous was opgeheven. En al spoedig zou het blijken, hoezeer machtsconcentratie op West-Java hoofdzaak werd. Aan deze politiek nu is vooral het kantoor van Patani ten offer gevallen ${ }^{1}$ ).

In October 1621 zou de verbonden tijd van 5-jarigen dienst van Druyff eindigen. Op 4 Nov. 1620 wees hij Coen hierop, verklarende, dat hij, als hij niet over zijn gezondheid had te klagen gehad, nog wel een jaartje in Patani had willen blijven, maar dat nu zijn ziekte hem noopte, tot het verzoek, van zijn post te worden ontheven. We mogen, ondanks Druyff's motiveering, gerust aannemen, dat ook de andere bezwaren, die zich als het ware tegen hem opeengestapeld hadden, aan

1) Vgl. over het bovenstaande: Tiele Eur. 5 II, p. 242, 306 v.; Copiebrief van Gerrit Frederiksz. Druyff aan beww., Patani, 4 Oct. 1618; J. P. Coen c.s. aan beww., in de Oude Zon, voor Mandalique, omtrent 3 mijlen bij Oosten Japara, 14 Jan. 1619 ((Col. Coen I, p. 416 v.); Gerrit Frederiksz. Druyff aan beww. kamer Amst., Patani, 26 Mt. 1619; Copiebrief van J. P. Coen aan Gerrit Frederiksz. Druyff, Jacatra, 2 Juni 1619 (Col. Coen II, p. 555 v.); idem aan de koningin van Patani, Jacatra, 2 Juli 1619 (Col. Coen II, p. 573 v.); Copiebrief van Pieter de Carpentier „ter ordonnantie van d' heer generael" aan Gerrit Frederiksz. Druyff te Patani (Col. Coen II, p. 688 v.); Copiebrief van J. P. Coen aan G. F. Druyff te Patani, Jacatra, 3 Juli 1620; Jan van Hasel aan J. P. Coen, Sangora, 4 Oct. 1620; Gerrit Frederiksz. Druyff aan J. P. Coen, Patani, 4 Nov. 1620; J. P. Coen c.s. aan beww., Jacatra, 8 Jan. 1621 (Col. Coen I, p. 606 v.); Copie-res. van G.-G. en Raden, fort Jacatra, 4 Aug. 1621 (Col. Coen III, p. 749 v.) ; Copie-instructie van J. P. Coen voor Jacques Colijn Jansz., gedestineerd tot de visite van de kantoren in Patani enz., Jacatra, 6 Aug. 1621 (Col. Coen III, p. 70 v.). 
zijn besluit niet vreemd geweest zijn. In denzelfden brief schrijft Druyff nog, mondeling vernomen te hebben - de verhouding tot zijn collega in Siam was, zooals we gezien hebben, niet bijzonder hartelijk -, dat Cornelis van Nieuwenroode eveneens ,verlost” wenschte te worden ${ }^{1}$ ). In Jacatra werd overeenkomstig het voorgaande beschikt. Met den visitateur ${ }^{2}$ ) werd in 1621 de instructie meegegeven, dat beide personen per eerste gelegenheid hun posten te verlaten en zich naar het hoofdkantoor te vervoegen hadden.

Zoo kwam voor Druyff het einde van zijn bestuursperiode. Toen hij in 1620 zijn ontslagaanvrage schreef, zal hij wel niet vermoed hebben, dat met het einde van zijn bewind tevens het eind van de factorij van Patani zou komen. Ik zal hierover nog nader schrijven. Genoeg zij het voorloopig, dat Druyff niet in Jacatra kwam als iemand, die zijn reputatie verspeeld had. Ondanks de vinnige opmerkingen van Coen over zijn onbezonnen wijze van inkoopen komt hij toch nog in eervolle posities in Compagnie's dienst voor, ook voordat hij in Februari 1622 verantwoording had afgelegd over de beschuldigingen, die tegen hem waren ingebracht ${ }^{3}$ ). Zoo wordt hij in December 1621 bij resolutie van gouverneur-generaal en raden aangesteld om tot nader order 't presidentschap van schepenen in Batavia waar te nemen. En in Januari 1622 staat hij bij een kwestie met de Engelsche Compagnie de door Coen benoemde gecommitteerden bij. We zullen hem daarna ${ }^{4}$ ) weer aantreffen in verband met de opheffing van Patani en andere kantoren. Onder 2 Januari 1623 eindelijk tref ik een resolutie aan, getrokken in 't fort Batavia, waarin aan Druyff wordt toegestaan, met de eerst afvarende schepen naar 't vaderland te vertrekken. $Z$ ijn verbonden tijd was toen reeds met omstreeks 15 maanden overschreden. Op 2 Februari 1623 werd hij door Coen benoemd tot opperhoofd op 't schip Alkmaar, dat zeilree naar 't vaderland lag ${ }^{5}$ ).

1) Zie p. 108 .

2) Zie p. 101 .

3) Zie p. 113.

4) In hoofdstuk VIII.

5) Vg1. over het bovenstaande: Gerrit Frederiksz. Druyff aan J. P. Coen, Patani, 4 Nov. 1620; Copie-instructie van J. P. Coen voor Jacques Colijn Jansz., gedestineerd tot de visitatie van de kantoren in Patani enz. (Col. Coen III, p. 70 v.) ; Copie-res. van G.-G. en Raden, fort Batavia, 29 Dec. 1621; Copieprotest, door Coen door zijn gecommitteerden aan de Eng. Compagnie geinsinueerd, Batavia, 3 Jan. 1622 (Col. Coen III, p. 122 v.); Copie-res. van G.-G. en Raden, fort Batavia, 2 Jan. 1623 (Col. Coen III, p. 933 v.) ; Copiecommissie van J. P. Coen voor GerritFrederiksz. Druyff, in 't schip Mauritius, 2 Febr. 1623. 


\section{DERDE HOOFDSTUK.}

\section{De Chineesche handel in Patani.}

We onderbreken, alvorens het einde van de factorij in Patani te beschrijven, ons historisch relaas, om op meer systematische wijze het belang van deze plaats voor de Compagnie in 't oog te vatten. Allereerst dan datgene, waarvoor deze vestiging in hoofdzaak bestond: de handel met de Chineezen. We zagen reeds, dat, waar China, ondanks onze pogingen, voor ons volk gesloten moest blijven, Patani bedoeld was als algemeen entrepot voor Chineesche waren. De twee voornaamste artikelen, welke hier, en gedeeltelijk ook in de bijkantoren van Siam en Sangora, door de jonken werden aangevoerd, waren zijde en porselein ${ }^{1}$ ). En van deze twee was de zijde weer het hoofdartikel. $\mathrm{Nu}$ dient dadelijk opgemerkt, dat men hiervoor niet uitsluitend van China afhankelijk was. Ook uit Italië kwam zijde. En verder zag men reeds duidelijk het belang in, dat Perzië voor dit artikel kon krijgen ${ }^{2}$ ). Maar zoo lang het kantoor van Patani bestond, kwam er nog geen Nederlandsche vestiging in dit land.

In Patani was het dus elk jaar weer een levenskwestie, of er jonken, en hoeveel er uit China met het vurig begeerde artikel zouden verschijnen. Wij kunnen vrij nauwkeurig nagaan, waar de zijde, die aan de onzen werd afgeleverd, vandaan moet zijn gekomen. Naar vier verschillende kwaliteiten wordt de in Patani aangebrachte zijde onderscheidenlijk Lanquinsche zijde genoemd, de fijnste kwaliteit, Oxhiou of Oxihou, de goede gemiddelde soort, Canton, de mindere gemiddelde soort, en Chincheau, de grofste. Wat deze namen betreft: Canton behoeft geen toelichting. Lanquinsche zijde moet, naar mij met stelligheid aan te nemen schijnt, voor Nankingsche zijde staan.

1) Van thee werd in de eerste helft der $17^{\circ}$ eeuw nog geen werk gemaakt; eerst in 1667 werd hiervan een belangrijke lading naar Holland gezonden (zie: Muller: Onze Vaderen in China, Gids 1917 I, p. 508).

2) Reeds in 1608 werd door Heeren XVII in een Memorie (12 April 1608) voor de admiralen, vice-admiralen, opper- en onderkommiezen in Indië er op aangedrongen, zoo mogelijk een verband met den koning van het vasteland van Hormus tegen de Portugeezen te sluiten, om o.a. „rouwe” (zie ben.) zijde uit Perzië te kunnen krijgen. 
Oxhiou zal wel hetzelfde zijn als Hockseu, dat ook als voor de Hollanders belangrijke handelsplaats in China voorkomt, en door Dr. H. P. N. Muller verklaard wordt als Foochow in de provincie Fokien ${ }^{1}$ ). Chincheau wordt door hem, in overeenstemming met Heeres, geïdentificeerd met Tsuentschou, gelegen tusschen Amoy en Foochow, eveneens in Fokien ${ }^{2}$ ).

Van zeer groot belang was voor de Compagnie de zijde in haar eenvoudigsten vorm, „rouwe” of ruwe zijde genaamd, d.i. de vezel, die gevormd wordt door een aantal samenklevende draden van den cocon van de zijderups ${ }^{3}$ ). Voor deze ruwe zijde was Amsterdam een der voornaamste markten van Europa. Merkwaardig plotseling was dit begonnen. We zagen boven ${ }^{4}$ ), hoe admiraal Heemskerck op 25 Februari 1603 voor Johor de Portugeesche kraak S. Catharina wist te vermeesteren. Tot de rijke lading hiervan behoorden 1200 balen ruwe Chineesche zijde, die een waarde van meer dan $21 / 4$ miljoen gulden vertegenwoordigden ${ }^{5}$ ). Deze zijde nu werd, naar het schijnt, nog vermeerderd met die uit een andere prijs ${ }^{6}$ ), in Augustus 1604 door de admiraliteit ${ }^{7}$ ) te Amsterdam in veiling gebracht. En waar juist toen, mede door mislukking van de zijdeteelt in Italië, de markt schaars voorzien was, kwam er een geweldige toeloop van handelaars uit heel Europa naar Amsterdam ${ }^{8}$ ).

Wat de kwaliteiten van de zijde aangaat, vinden we verschillende termen, die niet alle duidelijk zijn, en verschillende normen van indeeling, die elkaar misschien gedeeltelijk dekken. Het eenvoudigst is de indeeling naar de kleur: witte zijde was de fijnste, en ook de in

1) Onze Vaderen in China, Gids 1917 I, p. 325.

2) 1.1. Volgens mondelinge inlichting van Prof. Duyvendak is deze identificatie met Tsuentschou (= Chwan-chau $=$ Tsiien-chau $)$ inderdaad het waarschijnlijkst, hoewel niet geheel zeker.

3) Zie Dr. Leonie van Nierop: De zijdenijverheid van Amsterdam historisch geschetst, Tijdschrift voor Geschiedenis, 1930, p. 34.

4) Pag. 12.

5) Dr. Leonie van Nierop, p. 151.

6) Dr. L. van Nierop spreekt, 1.1., van een Portugeesch schip, dat eenige maanden na het genoemde door Van Warwijck voor Macao werd buitgemaakt. Dit strookt echter niet met het itinerarium van Van Warwijck, zie De Jonge, Opkomst III, p. 20 v.

7) Het was namelijk nog niet zeker, of de S. Catharina aan de Compagnie, die haar buitgemaakt had, zou worden toegewezen (vgl. ook Fruin: Een onuitgegeven werk van Hugo de Groot, Verspreide Geschriften III, p. 367 v.), en inen wilde met den verkoop niet op de beslissing wachten, uit vrees, dat de zijde door 't lange liggen zou kunnen bederven.

8) Dr. L. v. Nierop, p. 151 v. 
de stukken van de Compagnie verreweg het meest voorkomende. Daarbeneden in kwaliteit stond de gele zijde.

Verder zagen we, dat ook reeds de namen der bovengenoemde plaatsen van herkomst een bepaling van de kwaliteit impliceerden.

Ten slotte moet ik nog melding maken van een prijsopgave van koopmanschappen, geldig in September $1617^{1}$ ), waarin onderscheid wordt gemaakt tusschen ,thausham" ${ }^{2}$ ) of "thanscam” als allerfijnste zijdesoort, en een tweede soort ,gietsham" of ,stetscam" ${ }^{3}$ ), die evenwel door haar voortreffelijkheid de ,thausham" dicht nabij kwam.

Voor de beste zijdesoorten - en hiervan moesten onze factors in Patani het meeste werk maken - betaalde men daar ter plaatse ongeveer 180 realen per picol. Wel oordeelden de bewindhebbers in 1612, dat dit te veel was: men moest volgens hen niet boven de 140 realen gaan voor de beste zijde, daar anders de winst te gering werd ${ }^{4}$ ), maar deze prijs was kennelijk te laag: in 1614 schreef Coen aan bewindhebbers ${ }^{5}$ ), dat men zoowel te Bantam als te Patani voor de beste kwaliteit een som moest betalen van 170 tot 190 realen per picol, en ook Hendrik Janssen betuigt in $1616^{6}$ ) de onmogelijkheid om lager dan 170 realen te gaan. Trouwens dergelijke wenken uit patria schijnen meer de bedoeling gehad te hebben, onze factorijhouders tot zoo scherp mogelijk inkoopen aan te sporen, dan dat men beslist niet boven den genoemden prijs mocht gaan; Coen althans geeft in 1617 order aan Hendrik Janssen om, ondanks den dan vanwege de bewindhebbers geldenden maximumprijs van 170 realen, desnoods rustig daarboven te gaan ${ }^{7}$ ).

Bijzonder werden de zijdekoopers er voor gewaarschuwd, zich bij

1) Prijscourant van koopmanschappen, zooals die in Patani golden in Sept. 1617 , met verklaring van den handel aldaar.

2) Deze term in de spelling ,tausam” ook in een brief van Victor Sprinckel aan Jacques l'Hermite te Bantam, Patani, 16 Juni 1610.

3) Deze term als "gitsam” in een copiebrief van Victor Sprinckel aan beww. kamer Delft, Patani, 31 Oct. 1610, en een brief van Victor Sprinckel aan Jacques l'Hermite te Bantam, Patani, 2 Nov. 1610, terwijl in een factuur van 't cargasoen, geladen door Hendrik Janssen in de Zwarte Leeuw, Patani, 15 Oct. 1618, „gitsham t' hau" (misschien een mengvorm van beide termen?) voorkomt voor de allerbeste soort fijne ruwe witte zijde.

4) Brief uit naam der beww. aan Peter Segers te Patani, of opvolger, Amsterdam, 28 April 1612.

5) Deze brief uit Bantan, 10 Nov. (Col. Coen I, p. 52 v.).

6) Brief van Hendrik Janssen aan beww. te Amst., Patani, 25 Oct. 1616.

7) Copiebrief van J. P. Coen aan Hendrik Janssen te Patani, Jacatra, 23 April 1617 (Col. Coen II, p. 236 v.). 
hun handel geen „,crengen” in handen te laten stoppen ${ }^{1}$ ); dit was beslist minderwaardige zijde, die weliswaar officieel tot de witte zijde werd gerekend, maar het wit was niet zuiver. Verder waren de „,draeijen door den andren gecruijst, daer door dat se seer qualijcken can ghescheijden worden"; ook wilde deze soort geen verf aannemen, in tegenstelling met de goede soorten ${ }^{2}$ ). De waarde was dan ook heel gering.

Ook van weinig waarde was de vlos- of floretzijde, die gemaakt werd van het afval der cocons. Tenslotte verdient nog vermelding de poolzijde, blijkbaar een soort zijde met pluisvormende draden, die bij het bereiden van fluweel werd gebruikt, en reeds een primitieve bewerking, het ineendraaien, had ondergaan ${ }^{3}$ ). Hiervoor werd veel geld betaald; in Sangora werd althans in 1615 een hoeveelheid à 237 realen per picol gekocht ${ }^{4}$ ).

De ruwe zijde, door de Compagnie naar 't vaderland gezonden, werd in Amsterdam niet alleen verhandeld, maar ook verwerkt. De zijdenijverheid aldaar was, gelijk zooveel ambachten, een vrucht van de immigratie uit het Zuiden. Uit België en Noord-Frankrijk waren zijdewerkers in allerlei specialiseering in de steeds in bloei toenemende stad komen wonen, vooral na den val van Antwerpen. En zooals de plotselinge en-gros-aanvoer van op de Portugeezen buitgemaakte zijde $^{5}$ ) den roem van Amsterdam als zijdehandelsmarkt ineens gevestigd had, zoo had de verdere bereiding of het ,reeden” der zijde door de genoemde immigratie zijn belang als duurzaam bedrijf aldaar gekregen ${ }^{6}$ ). In de reederijen werd de ruwe zijde eerst ,toegemaeckt” tot een zuivere, ronde draad; soms werd ze daarvoor ook ineengedraaid. Daarop volgde eerst het twijnen of tweernen ${ }^{7}$ ). Moest de zijde worden geverfd, dan werd ze daarvoor meestal eerst ,,afgezoden" ${ }^{8}$ ), opdat zij de kleefstof zou verliezen, die haar hard maakte. Door deze bewerking, die de kwaliteit verhoogde, verloor het mate-

1) Ook „linckan” genoemd (Factuur van Hendrik Janssen van de goederen, geladen in 't jacht de Hazewind, Patani, 12 Juli 1612).

2) Memorie dienende tot den inkoop van de „rouwe” Chineesche zijde en alle andere "geverfde ofte affgesoden" zijden.

3) Van Dam I II, glossarium s.v. poolzijde; L. v. Nierop, p. 36 v.

4) Prijscourant van koopmanschappen, zooals die in Patani golden in Sept. 1617, met verklaring van den handel aldaar.

5) Zie p. 119.

6) Vgl. L. van Nierop, p. 32 v.

7) Het kwam ook wel voor, dat men de getweernde zijde direct van de Chineezen kocht.

8) Onjuist lijkt mij de verklaring van het afkoken in noot 1, p. 364 van de Van Dam-uitgave II I, waar de uitgever het losmaken van de oorspronke- 
riaal daarentegen $25 \%$ aan gewicht. Goedkoope zijdesoorten werden ook wel aan 't stuk geverfd ${ }^{1}$ ).

Maar uit Patani ging niet alleen ruwe zijde naar 't vaderland, die daar verhandeld of verwerkt moest worden; onze factorijhouders kochten er ook van de Chineezen de zijden stoffen kant en klaar, met een algemeenen verzamelnaam zijdewaren of ook wel zijdelakenen genoemd. Van deze zijdewaren bestond er een groote verscheidenheid, zoowel naar soort, kleur als bewerking. Onder de gezochte soorten moet ik in de eerste plaats de armosijnen noemen, een weefsel, waarvan de naam begrijpelijkerwijs met de Perzische stad Hormus in verband wordt gebracht, al is deze etymologie blijkbaar niet geheel zeker $\left.{ }^{2}\right)$. De armosijnen waren van lichte zijden stof gemaakt; er kwamen zwarte voor, maar ook gekleurde, zoo blauwe, gele, roode en oranje. Soms waren ze "gewrocht”, bewerkt dus, wat wel in tegenstelling zal staan tot effen, terwijl er ook ,gebelde" armosijnen gemeld worden ${ }^{3}$ ), dat is dus gebeelde : van figuren voorzien. De armosijnen waren gewild als voering: zoo voor dekens en voor ,beddecleden", d.i. spreien. Naast de armosijnen dienen de damasten te worden genoemd, een welbekende term, afgeleid van Damascus, en, gelijk men weet, niet uitsluitend voor zijden stoffen gebruikt. Ook hiervan kwamen er in allerlei kleuren voor, als zwarte, witte, violette, blauwe, groene en bruin-blauwe. Ook van de damasten kwamen er „gebeelde" voor. Verder treden onder de gewone zijden stoffen nog de satijnen op den voorgrond, een genre, waarvan de naam hoogstwaarschijnlijk moet worden afgeleid van Zaitun $=$ Chwan-chau in Fokien ${ }^{4}$ ). Ik trof hiervan aan: zwarte, witte, roode en blauwe, gefigureerde, gebeelde ${ }^{5}$ ) en ongebeelde. Evenals de armosijnen deden ook de satijnen wel dienst als voering voor dekens.

Min of meer als apart genre, maar toch ook wel onder de zijdelakenen gerekend, treffen we aan de fluweelen. Ook hierbij vinden we wederom allerlei kleuren: zwart, wit, rood, groen, blauw en violet. Dat we ook gebloemd fluweel aantreffen, wekt geen verbazing. Ook met fluweel worden soms dekens gevoerd.

lijke draden van den cocon afzieden noemt. Dit losmaken geschiedde echter in lauw, niet in kokend water.

1) Vgl. L. v. Nierop, p. 34 v., 40.

2) Zie Hobson-Jobson i.v. Ormesine.

3) Factuur van Hendrik Janssen van de goederen, door hem geladen in 't jacht de Hazewind, Patani, 12 Juli 1612.

4) Zie Hobson-Jobson i.v. Satin. Vgl. over Chwan-chau p. 119, noot 2.

5) Deze twee aanduidingen zullen dus wel 't zelfde beteekenen. 
Het spreekt vanzelf, dat de prijzen van de genoemde zijdelakenen zeer varieerden, al naar grootte, bewerking en kwaliteit der exemplaren.

Wat werd nu van de zijden stoffen, waarover we gesproken hebben, vervaardigd? We zagen reeds, hoe zijde en fluweel te pas kwamen bij de vervaardiging van dekens. Deze werden in rijke verscheidenheid van de Chineezen betrokken, gestikte, geborduurde en opgenaaide. We mogen dan ook aannemen, dat de ,over-zeesche dekens”, zooals Huygens ze noemt in 't huis van een rijke ,malade imaginaire" ${ }^{1}$ ), voor een goed deel in Patani ingekocht geweest zullen zijn. Ook voor spreien, ook sargien en beddekleeden genoemd, werd, gelijk we reeds gezien hebben, zijde gebruikt. Verder treffen we gestikte, geborduurde en opgenaaide ,cussenbladeren” aan, waarvoor fluweel of zijde gebruikt was. Men moet hierbij niet denken aan kussensloopen voor 't gebruik op bedden, maar aan overtrekken van zitkussens, die in den toenmaligen tijd, bij de hardheid der meubels, een zooveel grootere, althans zooveel noodzakelijker rol speelden dan nu. Dat vooral de kussens, waarop de regenten ,zaten”, van bijzonder kostbare bewerking moesten zijn, spreekt vanzelf. Verder worde gewezen op de behangsels, zoowel voor kamers als voor ledikanten bestemd ${ }^{2}$ ). Ten slotte noem ik nog geborduurde tafelkleeden, en de rabatten, dat zijn afhangende stukken stof, voor verschillende doeleinden gebruikt. Zoo lezen $\mathrm{we}^{3}$ ) van „rabatten van ledicanten ofte schoustenen", in Patani vervaardigd.

Voordat de zijde uit Patani werd verzonden, moest natuurlijk zorg gedragen worden voor het doeltreffend emballeeren, zoowel van de pakken ${ }^{4}$ ) of ",ferdeelen” ruwe zijde als van de zijdewaren. Men gebruikte hiervoor vaak ,cassen”, d.i. kisten, of ook „,canasters ofte corven", terwijl ook wel de balen zijde met huiden of leer werden omsloten. Blijkbaar is de hoofdzorg geweest, de zijde goed van alle vocht af te sluiten. Zoo wordt in 1612 namens bewindhebbers naar Patani geschreven, dat de zijdelakenen, die van daar naar 't vaderland zouden worden gezonden, goed moesten worden verpakt in dichte

1) „Daer light een' siecke pop Gewentelt in 't fluweel van over-zeesche dekens”, in „Een onwetend medicyn”.

2) Zoo bericht Mateo Coteels in een brief aan Hendrik Janssen te Patani, 20 Mei 1613, dat in 't vaderland wel ,getrokken” waren „behangsels geboorduurt op goet fluweel, ende dat op 't costelyckste".

3) Copiebrief van Victor Sprinckel aan beww. kamer Delft, Patani, 31 Oct. 1610.

4) Vgs. Dr. L. van Nierop, p. 35, bestond een pak zijde uit 7 bussels, een bussel uit 6 massen en een hoofdmas, een mas wederom uit 15 strengen. 
kisten, die goed moesten ,toe geperefynt" ${ }^{1}$ ) zijn en bovendien bekleed met leer of ",canefas" ${ }^{2}$ ), opdat ze onderweg niet aan elkaar zouden plakken of bederven, want daardoor zou meer dan de helft van de waarde verloren kunnen gaan ${ }^{3}$ ).

$\mathrm{Bij}$ het inkoopen zoowel van ruwe zijde als van de zijdelakenen werd groote kennis van zaken vereischt: al mocht men voor het koopmansbedrijf bij de Compagnie in 't algemeen een goeden aanleg bezitten, toch kon men, speciale ervaring in de zijdebranche missende, de meest nadeelige vergissingen maken. Dit werd ook door bewindhebbers duidelijk ingezien. Groote voorzichtigheid tegenover de Chineezen was geboden, ,want”, zoo schreven ze in 't laatst van 1612 naar Patani ${ }^{4}$ ), ,het een volck vol archlisticheyt en bedroch is, soe in haer coopmanschap subtylycken te vervalschen, als in andere saecken". Ze zagen er niet tegen op, in de fijne zijde crengen te "voeyeren" ${ }^{5}$ ), reden, waarom het noodig geacht werd, bij inkoop ter contrôle eenige bussels of zelfs strengen te openen. $E_{n}$ in de reeds aangehaalde memorie over den zijdeïnkoop ${ }^{6}$ ) wordt eveneens aanbevolen, in geval van twijfel een of twee strengen te openen ,en de selve proeven te scheijden, ende soo se haer qualijcken wilt laeten scheijden, dat is een seecker teecken, dat het een crenge is”. De zijde moest „effendradich” of, zooals men ook zei, ,effensnarich” zijn. En wat de zijdelakenen betreft, moest er goed op gelet worden, of wel alle daarvoor gebruikte zijde afgezoden was : dikwijls kwam het namelijk voor, dat de schering van ruwe zijde en alleen de inslag van afgezodene was. In dit geval mocht men natuurlijk lang zoo'n hoogen prijs niet betalen als wanneer men met stukken van louter afgezoden zijde te doen had. Verder was ook steeds contrôle noodig om te zorgen, dat men de juiste kleuren kreeg, die in 't vaderland gewenscht waren.

Het is dan ook begrijpelijk, dat soms door de Compagnie speciale „zijdekenners” werden uitgezonden, temeer waar men, blijkens : het hierboven behandelde, in ons land in dien tijd reeds een groote mate van vakkennis kon opdoen. Reeds op den eersten Compagniestocht, dien van Van Warwijck, wordt 30 Mei 1603 op 't admiraalsschip

1) Dus met paraffine dicht gemaakt.

2) Canvas.

3) Brief uit naam der beww. aan Peter Segers, koopman te Patani, of opvolger, Amsterdam, 28 April 1612.

4) Copiebrief uit naam der beww. aan Peter Segers te Patani, 15 Dec. 1612.

5) Misschien gelijk voederen $=$ voeren ?

6) Pag. 121, noot 2. 
Mauritius besloten, dat Paulus van Soldt ${ }^{1}$ ) te Bantam zal worden gelaten, daar hij geacht wordt een zeer goed kenner van Chineesche zijcle te zijn $^{2}$ ). En onder de instructies voor de reis van Verhoeff ${ }^{3}$ ) vinden we vermeld, dat, mocht het gelukken, den handel in China te verkrijgen, daar onder andere Peter Segers zal worden gelaten als "sydelakencooper ende boeckhouder" ${ }^{4}$ ), terwijl voor Patani als zijdekoopman en assistent zekere Willem Clayss. bestemd is ${ }^{5}$ ). Ten slotte: op 5 September 1609 resolveeren de Heeren XVII, dat met de vloot van Pieter Both drie zijdekenners naar Indië zullen vertrekken, twee te benoemen door de kamer van Amsterdam, één door die van Zeeland.

Omstreeks 1608 vooral was de belangstelling van bewindhebbers voor de Chineesche zijde buitengewoon groot. Met het jacht de Goede Hoop werd op 4 Mei 1609 een memorie aangebracht ,voor de manhaften, vroomen, onsen seer lieven ende bysonderen, de Admiraelen, Vice-admiraelen, Opper- ende Onder-commiesen in Oost-Indien" ${ }^{6}$ ), waarin onder andere wordt gezegd: „Den handel van China wort ul. oock op 't hoochste ende wel ernstelick gerecommandeert, voornamentlick van de rouwe syde, daerop goede proffyten syn te doen ende oock seer groote quantiteyt can worden verhandelt, maecken oock seer groote neeringhe ende welvaert onder het arbeytsvolck, ende so denselven handel op China in gheender manieren en ware te becomen, soo moet men nochtans sien, dat men de rouwe syde over andere plaetsen als Patana ende andere plaetsen become”. En Sprinckel zegt

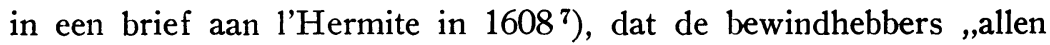
dach schrivende syn niet dan om syde". Hij gaat zelfs zoo ver, te beweren, ,dat de syde is de proffytelycxste coopmanschap, die hier in Indiën ghedaen wort". Het is waar, dat de aandrang, om zich van den Chineeschen handel te verzekeren, omstreeks 1611 wat geluwd is,

1) Deze is van beteekenis geworden voor de vestiging der Nederlanders aan de Koromandelkust. Zie mijn proefschrift „De vestiging” enz. Vgl. verder p. 26, noot 1 .

2) Registerboek der ordonnantiën van den breeden raad op 't schip Mauritius, 26 Juni $1602-22$ Oct. 1603.

3) Vertrokken Dec. 1607.

4) Vg1. p. 54 v.

5) Ordonnantie en instructie voor de kooplieden e.a., die in Indië aan land zullen blijven (Kol. aanww. 1910. XV. $N^{\circ} 1$ : Exemplaar van de diverse instructies voor de reis van Verhoeff).

6) Geschreven 11 of 12 April 1608 .

7) Copiebrief van Victor Sprinckel aan Jacques 1'Hermite de Jonge te Bantam, Patani, 25 Sept. 1608 (Copieboek V. S.). 
daar toen in patria het overwegende punt gevonden werd, eerst de positie van de Compagnie in de Molukken te verzekeren ${ }^{1}$ ).

Maar niet alleen naar Nederland werd de Chineesche zijde verzonden, ook voor Japan was dit artikel van groot belang: reeds Van Neck zegt in zijn reisverhaal, opgesteld voor de bewindhebbers ${ }^{2}$ ), dat de Japansche handelaars in Patani de zijde komen koopen, die de Chineezen daar brengen. Geen wonder, dat de Hollanders, zoo spoedig ze vaste voet in Japan hadden gekregen, er op uit waren, het voordeel van dezen handel voor zich te verzekeren. De zijde werd dan ook een belangrijk artikel onder de ladingen, die uit Patani naar Japan werden gezonden. Maar ook de Indische archipel „trok” Chineesche zijde. Reeds in een informatie over den Indischen handel, meegegeven aan Van der Hagen ${ }^{3}$ ), vinden we de volgende passage: „De Chinesen brengen hier ${ }^{4}$ ) oock wel ongetwernde syde,.... ende is oock wel getrocken op Moluccus \& Banda, maer dan moet het van allerhande slach wesen, soo root, blau, geel, groen, wit \& andere diergelycke couleuren". En uit een gegeven van $1620^{5}$ ) vernemen we, dat in Patani armosijntjes en andere Chineesche waren besteld zijn voor Timor en Solor.

Het tweede belangrijke artikel, dat van de Chineezen werd gekocht, was het porselein. In tal van soorten werd dit aangebracht. Onder de porseleinen voorwerpen, die in Patani aangevoerd of verlangd werden, behooren in de eerste plaats de schotels, ook wel plateelen of ",beteelen" genoemd ${ }^{6}$ ). Men treft nog als bijzondere soorten "telyooren”, waarmee dus etensborden bedoeld zullen zijn, boterschotels, fruitschotels en proefschaaltjes. Verder vallen de koppen te noemen, waaronder merkwaardig zijn de ,cameelscoppen”, een woord, dat, volgens een door mij ontvangen inlichting ${ }^{7}$ ), misschien

1) Groeneveldt, p. 48.

2) 28 Juni $1600-5$ Juli 1603 .

3) In Rouffaer en Juynboll, d1. I, bijlage III.

4) D.i. in Patani.

5) Gerrit Frederiksz. Druyff an J. P. Coen te Jacatra, Patani, 8 Mt. 1620.

6) Misschien is het laatste woord een verbastering van plateelen. In ieder geval worden er schotels mee bedoeld. Vgl. den copiebrief van Lambert Jacobsz. Heyn aan Victor Sprinckel, Ajudhja, 7 Mei 1608, met de factuur door Victor Sprinckel van goederen, naar 't vaderland gezonden met de Gouda, Patani, 25 Sept. 1608.

7) Van den heer N. Ottema, conservator der ceramische afdeeling van het Friesch museum te Leeuwarden. Bevestigd wordt dit door een inlichting van Dr. F. W. Stapel. 
een verbastering is van kandeelskoppen ${ }^{1}$ ). Eigenaardig is de term „,caractarcoppen” ${ }^{2}$ ). Naar alle waarschijnlijkheid zijn dit koppen met karakters $=$ (Chineesche) letterteekens er op. Ook vind ik gesproken van ,coppen, die overdect zyn, ooc die nyet overdect zyn”3). Verder de kommen, waaronder opvallend zijn de ,clapmutsen” ${ }^{4}$ ) en de „,mostaerd sausieren”. Dan de potten, waaronder er b.v. zijn, die dienen voor het vervoer van gember, en ook mosterdpotten ${ }^{5}$ ). En dan komen er nog andere genres voor, als kannen ${ }^{6}$ ), flesschen, kelken, wijnpinten en zoutvaatjes.

Bij het verpakken van porselein moest, zoo mogelijk, nog meer voorzichtigheid betracht worden dan met de zijde: maar al te licht kon het kostbare aardewerk breken ! Ten deele werd het in vaatjes vervoerd, waarbij dan allicht papier of een andere zachte stof tusschen de verschillende stukken in gedaan zal zijn; wanneer de vorm der porseleinen voorwerpen het meebracht, kon men ze ook samenbinden. Schotels b.v. pasten dikwijls goed in elkaar, en zoo vinden we deze zoowel verpakt in vaatjes als in ,,biesen bonden” ${ }^{7}$ ), d.w.z. in biezen bundels. Waar we bij het binden en pakken van porselein naast biezen ook nog gesproken vinden van rottang, daar zullen we wel niet aan de gewone rotansoorten moeten denken, doch meer aan coir, die uit den cocosbolster wordt bereid. In het verhaal van Roelof

1) Kandeel : warme wijn met melk, suiker, eierdooiers en kaneel, een drank, die bij geboorten enz. geschonken werd.

2) Factuur der goederen, gescheept door Coen in 't schip Mauritius, fort Batavia, 1 Febr. 1623.

3) Rouffaer en Juynboll, dl. I, bijlage III.

4) "Groote fyne commen ofte clap mutsen" (Memorie van zijde e.a. goederen, door Victor Sprinckel uit China ontboden, 28 Juni 1608). De benaming is in Friesland nog in gebruik voor holle bakjes of diepe schoteltjes. Misschien zoo genoemd wegens vormgelijkenis met een gladde ondermuts, die ook klapmuts genoemd wordt?

5) Dit zullen dus wel potten zijn, waarin de mosterd bewaard, in tegenstelling met de ,sausieren" (saucières), waarin hij opgediend werd.

6) In de memorie, genoemd in noot 4, worden gevraagd: „,500 cannekens met hengsels ende pipen".

7) (Factuur van 't cargasoen, door Hendrik Janssen in de Zwarte Leeuw geladen, Patani, 15 Oct. 1618). Ook de vorm ,bont” meervoud komt voor: In 't journaal van de reis van Warwijck (In Begin ende Voortg. I, p. 82) wordt bij de lading van de S. Antoni (zie p. 24) gesproken van „6000 bont porceleynen". Dr. J. de Hullu spreekt - in: De porceleinhandel der OostIndische Compagnie en Cornelis Pronk als haar teekenaar, Oud-Holland, 33 jaarg. (1915), p. 54 - van met papier omwikkelde ,bondels" porselein. Dit laatste is kennelijk ons woord bundel. Wat bond en bont betreft, dit zal wel oorspronkelijk slaan op de verpakking, en later als een soort inhoudsmaat gebruikt zijn. 
Roelofsz over den tocht van Van Neck toch ${ }^{1}$ ) is sprake van rottang „oft touwwerk van cocosbasten gemaakt”.

Een paar voorbeelden van belangrijke ladingen porselein uit Patani mogen hier volgen. In October 1618 zendt Hendrik Janssen met het schip de Zwarte Leeuw ${ }^{2}$ ) naar Bantam : aan pas ingekocht porselein : 48 groote schotels, 920 schotels van de tweede soort, 475 van de derde soort, 120 van de vierde soort en 55 groote porseleinen kommen, samen 1618 stuks, die met inbegrip der onkosten, erop gedaan, $561 \frac{1}{4}$ reaal $=\mathrm{f} 1347 .-\ldots$ - kostten. Verder aan porselein, dat Hendrik Janssen reeds vroeger had ontvangen, : 9 heele schotels, kostende f 16.4.-, 1078 halve schotels: f 983.2.-, 696 z.g. derde parten ${ }^{3}$ ), kostende f 417.12 . - 338 kwartschotels $^{4}$ ): f 135.4.-, 26 groote porseleinen kommen: f 57.12.-, en 900 fijne boterschotels : f 108.-.-, in totaal 3047 stuks, met inbegrip van onkosten komende op f 1723.6.- ${ }^{5}$ ). En een enorme lading porselein, uit de bocht van Patani afkomstig, wordt in Februari 1623, als onze vestigingen aldaar reeds gelicht zijn ${ }^{6}$ ), uit Batavia met 't schip Mauritius naar 't vaderland gezonden ${ }^{7}$ ): uit Patani niet minder dan 51455 stuks, als halve schotels, derdepart schotels, kwarten dito, halve en fijne $1 / 3$ ",cameelscoppen”, „mostaerdsausieren”, ,clapmutsen” en halve "clapmutsen”, boterschotels, "caractarcoppen”, groote kommen in verschillende kwaliteit, kannen van verschillende grootte, kleine potten, groote potten met gember gevuld, en fijne kelken van verschillende grootte. Uit Sangora behoorden bij deze lading nog 6586 stuks : halve schotels, derdepart schotels, kwarten, boterschotels, halve „cameelscoppen”, groote en kleine flesschen, kommen en "mostaerdsausieren”. Deze geheele lading porselein uit beide plaatsen kwam, met alle onkosten, waaronder begrepen ,aenpart in de jaerlijckse schenckaige”, te staan op $35423 / 4$ realen.

De eerste gelegenheid, waarbij mij is gebleken, dat van 't vaderland uit het koopen van 't Chineesche porselein aangemoedigd werd, is de tocht van Matelief naar Indië in 1605. In een memorie van de bewindhebbers voor dezen admiraal toch lezen we: „Alle Chinesche

1) In Begin ende Voortgangh I, p. 17.

2) Zie p. 84 .

3) Waarvan 6 stuks gebroken.

4) Waarvan 8 stuks gebroken.

5) Zie de factuur, genoemd in noot 7 van p. 127.

6) Zie hoofdstuk VIII.

7) Zie: Factuur der goederen, gescheept door order van J. P. Coen in de Mauritius, Fort Batavia, 1 Febr. 1623. 
waren, als syde, suycker, porseleyn ende andere meer, sal men door die Chinezen in grote abundantie tot Patana ende Bantam doen brengen"1). Deze aanbeveling werd ook aan Verhoeff meegegeven, die in 1607 naar Indië vertrok ${ }^{2}$ ). Het is echter niet bewezen, dat dit porselein speciaal voor 't vaderland bestemd was. Immers we treffen onder de instructies voor dezen admiraal een gegeven aan, dat nog niet van groote belangstelling in 't vaderland getuigt. Wat porselein betreft, zoo lezen we daar ${ }^{3}$ ), mag men wel een partij plat, grofachtig goed brengen, zooals Jacob van Neck in Patani gekocht heeft, en wel van zoodanige grootte, dat men er een Hollandsche kaas in kan opdienen, maar als men dit porselein niet onder de ,gharniringhe" ${ }^{4}$ ) brengen kan, dan dient er niet veel van gekocht te worden, daar de vracht te duur is om het in 't ruim te laden. In 1612 echter bestaat er groote behoefte aan porselein. Namens de bewindhebbers wordt dan naar Patani geschreven ${ }^{5}$ ), dat er geen porselein in Nederland is, en dat men daarom zoo veel moet zenden als er te krijgen is, van alle soorten, behalve van de allergrootste soort schotels, die weinig ,getrokken" zijn. Hiermee klopt, wat Coteels in 1613 aan Hendrik Janssen schrijft ${ }^{6}$ ): fijn porselein kan in Patani niet te veel worden ingekocht, maar de groote schotels moet men niet koopen. Daarna schijnt in de behoefte van 't vaderland allengs voorzien te zijn, ja meer dan dat: in 1617 is er zelfs overvloed, en begeeren de bewindhebbers tot nader order geen nieuwe zendingen ${ }^{7}$ ).

Maar behalve 't vaderland als verreweg het voornaamste afzetgebied had de Compagnie ook andere débouchés voor haar porselein-

1) Zie: copiebrief van het verzeilen van de vloot van Matelief, genoemd p. 28 , noot 3 .

2) Memorie voor Pieter Willemsz. Verhoeff c.s., Koloniale aanwinsten 1910, $\mathrm{XV}, \mathrm{N}^{\circ} 1$.

3) Memorie op de koopmanschap, Koloniale aanwinsten 1910, XV, $\mathrm{N}^{\circ} 1$.

4) Glossarium Van Dam I I, ed. Stapel, s.v. garnier(ing); „bekleeding van het ruim met planken, rotan of bamboe, ter bescherming van het schip en lading en om de laatste beter te kunnen opstuwen. Ook de laag rijsbundels, onder in 't ruim en waarop de lading rust". Onder zal in ons geval wel „tusschen" beteekenen.

5) Brief uit naam der beww. aan Peter Segers te Patani of opvolger, Amst., 28 April 1612.

6) Mateo Coteels aan Hendrik Janssen te Patani, 20 Mt. 1613.

7) Copiebrief van J. P. Coen aan Hendrik Janssen te Patani, Jacatra, 17 April 1617 (Col. Coen II, p. 226 v.); idem aan C. van Nieuwenroode te Sangora, Jacatra, 17 April 1617 (Col. Coen II, p. 230); idem aan Hendrik Janssen te Patani, Jacatra, 23 April 1617 (Col. Coen II, p. 236 v.).

Verh. dl. I. 
handel. In de reeds genoemde informatie voor Van der Hagen ${ }^{1}$ ) wordt gezegd, dat het door de Chineezen in Patani gebrachte aardewerk „ooc zeer getrocken is in de Moluccos en Banda, maer meest groff en middelbaer, te weten groote platteelen, middelbare en cleene coppen, die overdect syn, oock die nyet overdect syn" ${ }^{2}$ ). De geschiktheid van de Molukken als afzetgebied wordt in 1613 bevestigd door Coteels ${ }^{3}$ ), die ook de Koromandelkust als zoodanig vermeldt.

Mochten zonder eenigen twijfel zijde en porselein de belangrijkste goederen zijn, welke door de Chineezen in Patani aangevoerd werden, ze waren bij lange na de eenige niet. Herhaaldelijk treft ons bijvoorbeeld het belang van den suikerhandel. Tweeërlei soort brachten de Chineezen aan: „poeyer suycker” en ,stock ofte candijs suycker”. Van de poedersuiker verlangde men de goede, witte soort, waarvoor van 3 tot 4 realen per picol werd betaald; de kandijsuiker was iets duurder: men betaalde er 4 à realen voor. Oorspronkelijk werd door de bewindhebbers weinig prijs gesteld op overzending van dit artikel naar 't vaderland, althans Verhoeff wordt geinstrueerd, dat men prima kwaliteit suiker weliswaar in de schepen zal laden, doch alleen als ballast, daar zij de vracht niet zou kunnen opbrengen ${ }^{4}$ ). Later schijnt hier verandering in gekomen te zijn: Coen schrijft in 1619 aan Druyff, dat de bewindhebbers gaarne goede witte kandijsuiker, mits tegen redelijken prijs ingekocht, zouden ontvangen ${ }^{5}$ ). Patani was in dien tijd voor den suikerinkoop nog van des te meer belang, daar dit artikel op Java nog niet als stapelproduct geteeld werd; later werd de suikercultuur in 't groot er voornamelijk met hulp van Chineezen ingevoerd ${ }^{6}$ ).

Verder dient de Chineesche gember genoemd, waarbij een paar maal Canton als plaats van herkomst wordt vermeld. Deze werd dikwijls als geconfijte gember ingekocht, en gold dan van $51 / 2^{7}$ ) tot 11 realen per picol. Soms ook confijtte men de gember zelf, en ver-

1) Zie p. 126 en 127 noot 3.

2) Vgl. p. 127.

3) In 't schrijven, genoemd op p. 129 noot 6.

4) Memorie voor Pieter Willemsz. Verhoeff c.s. (Kol. Aanwinsten 1910, $\mathrm{XV}, \mathrm{N}^{\circ} 1$ ).

5) Copiebrief van J. P. Coen aan Gerrit Ferederiksz. Druyff, Jacatra, 2 Juni 1619 (Col. Coen II, p. 555 v.).

6) Groeneveldt, p. 275, noot 2.

7) In Februari 1623 vinden we zelfs melding gemaakt van in Sangora ingekochte gember à 3 realen per picol, doch het is niet zeker, of dit geconfijte was. (Factuur der goederen, door order van J. P. Coen gescheept in de Mauritius, fort Batavia, 1 Febr. 1623). 
smolt dan een hoeveelheid suiker tot stroop ervoor. De verzending geschiedde in potten, van porselein of ander aardewerk, of in vaten. Daar er, mogen we Hendrik Janssen gelooven ${ }^{1}$ ), bij den gemberverkoop veel bedrog gepleegd werd, zal ook hier, evenals bij de zijde, groote voorzichtigheid geboden geweest zijn.

Van beteekenis onder de Chineesche artikelen is ook de rhabarber geweest, d.w.z. de medicinale wortel van de Chineesche rhabarber, die vooral als laxans gebruikt werd ${ }^{2}$ ), en verder de eveneens medicinale radix China, een gedroogde wortel, die tegen huidziekten aangewend werd ${ }^{3}$ ). Maar hiermee is de lijst nog lang niet uitgeput; ik noem van de andere begeerde artikelen nog agelhout ${ }^{4}$ ), aluin, calmus odoratus ${ }^{5}$ ), vermiljoen, arak, kamfer, papier en kwikzilver.

De jonken, die de begeerde Chineesche artikelen naar Patani voerden, plachten in het voorjaar, van Februari tot Mei, te komen. Ze profiteerden dan van den wintermoesson, en konden met gunstigen Noord-Oostenwind van China naar Patani varen. Het was dus wenschelijk, dat het noodige kapitaal tegen dien tijd door de Nederlandsche schepen uit Bantam of Batavia werd aangebracht. Om te maken, dat zooveel mogelijk van de begeerde artikelen werd aangebracht, schreef men blijkbaar uit Patani wel eens brieven, in 't Chineesch vertaald, aan kooplieden in China, om dezen tot zoo groot mogelijke zendingen aan te moedigen ${ }^{6}$ ). De gewone methode, die ik boven al eens heb aangeroerd ${ }^{7}$ ), was het maken van voorkoop met de Chineezen, die in Patani waren gekomen: men bestelde een bepaalde hoeveelheid goederen, tegen een vastgestelden prijs, die in 't volgende jaar, bij nieuw bezoek dier Chineezen, geleverd moesten worden. Dit is blijkbaar voor 't eerst in 't groot in Patani gedaan

1) Hendrik Janssen aan beww. te Amst., Patani, 20 Oct. 1614.

2) Zie p. 55 noot 3 .

3) Glossarium Van Dam I I, ed. Stapel, i.v.

4) Het welriekende hout van den aloë-boom, als reukhout en medicijn gebruikt. Volgens door Roelof Roelofsz (Begin ende Voortg. I) gebruikte bronnen ook aangewend bij balseming van lijken en ook bij lijkverbranding. Hoe ouder de boom is, des te sterker is de reukkracht van het hout, hetwelk dan tevens donkerker is van kleur, zwaarder van gewicht en duurder in prijs. Zie 't verhaal van Roelof Roelofsz, p. 21 v.; Linschoten Itinerario I, p. 83, noot 2; De eerste Schipvaart, ed. G. P. Rouffaer en J. W. IJzerman I, Linsch. Ver. VII, p. 157 , noot 54 en 55 ; glossarium Van Dam, ed. Stapel, I II, i.v. aloëhout en II I, i.v. aguila.

5) Kalmuswortelstok, als geneesmiddel gebruikt.

6) Zoo in een copiebrief van Victor Sprinckel aan Jacques l'Hermite de Jonge te Bantam, Patani, 25 Sept. 1608 (Copieboek V. S.).

7) Zie p. 102 . 
in $1608^{1}$ ), en daarna treffen we het herhaaldelijk weer aan ${ }^{2}$ ). Bij dezen voorkoop moest natuurlijk zooveel mogelijk worden voorkomen, dat mindere kwaliteit dan de afgesprokene werd geleverd. Als Victor Sprinckel in 1608 voorkoop van drie verschillende soorten zijde maakt, behoudt hij als garantie drie monsters onder het "casset" 3 ) der verkoopers, en geeft hij drie dergelijke onder zijn eigen "casset” mee ${ }^{4}$ ). Dat de bemoeienis der onzen in Patani nog verder ging dan alleen zich goede kwaliteiten van de Chineesche artikelen te verzekeren, blijkt uit een prijscourant van koopmanschappen van $1617^{5}$ ), waarin geklaagd wordt, dat men weinig succes gehad heeft met zijn pogingen, de Chineezen er toe te brengen, de rouwe zijde eerst af te koken, voor ze die laten bewerken, en zoodanig te kleuren, als voor 't vaderland gewenscht schijnt. Ook kan men hen er moeilijk toe krijgen, porselein te brengen volgens uit Patani meegegeven „patroonnen ofte fatsoenen”. Soms is men niet zeker, of een gewenscht artikel als zoodanig leverbaar is: Victor Sprinckel verlangt in 1608 van de Chineezen ,,500 wyn pinten, (so) sy se conden maken”, en „1000 sout vaetkens, so se die conden maken" $\left.{ }^{6}\right)$. Men ziet, dat we hier reeds eenigszins den kant op gaan van het "Chine de commande" uit lateren tijd, waarbij in alle bijzonderheden voorstellingen worden aangegeven, die men op het porselein wil doen aanbrengen.

Dikwijls waren de Chineezen, welke tusschen Patani en China voeren, weinig bemiddeld, ,een deel lichte povre cappellaenen”, zooals Hendrik Janssen zich ergens uitdrukt ${ }^{7}$ ). Meestal moesten ze, om hun handel te beginnen, geld op bodemerij opnemen, en dat wel, aangezien de reizen vrij ver waren, tegen hooge rente. Om hun daarom die tochten ondanks deze nadeelen toch aantrekkelijk te maken, gaf men hun in Patani òf algeheele vooruitbetaling in geld of goederen, of

1) Victor Sprinckel aan beww. te Amst., Patani, 25 Sept. 1608.

2) In een copie-cedule van schipper Sanguan, Patani, 13 Mei 1608, vinden we in een dergelijke voorkoop-overeenkomst vermeld, dat zijde, die nog boven de overeengekomen leverantie aan de Hollanders zal worden geleverd, tot iets hoogeren prijs gekocht zal worden.

3) Zeker verbastering van cachet: zegel.

4) Zie de copie-cedule, genoemd in noot 2; Copie-cedule van Empo, Patani, 22 Mei 1608; Victor Sprinckel aan beww. te Amst., Patani, 25 Sept. 1608.

5) Prijscourant van koopmanschappen, zooals die in Patani golden in Sept. 1617 , met verklaring van den handel aldaar.

6) Memorie van zijde e.a. goederen, door Victor Sprinckel ontboden uit China, 28 Juni 1608.

7) Copiebrief van Hendrik Janssen aan 't kantoor te Bantam, Patani, 15 Nov. 1615. 
althans een gedeelte van de gecontracteerde som op de hand. Daar dit voor de onzen weer groot risico meebracht, completeerde men deze methode door borgstelling : als borgen, dat de vereischte goederen werkelijk geleverd zouden worden, werden dan ,suffisante mannen” genomen, bijvoorbeeld hooge inlandsche dignitarissen of in Patani gevestigde Chineezen. Ook diende bij iedere transactie nog overeengekomen te worden, wie het risico ter zee op zich zou nemen. Hierover bestond blijkbaar geen algemeene regel. Zoo zien we bij een overeenkomst in Mei 1608 ${ }^{1}$ ), dat de Hollanders het risico zullen dragen van een door hen naar China meegegeven hoeveelheid ivoor, terwijl omgekeerd de koopers daarvan het risico op zich nemen voor de goederen, welke zij er voor zullen terugbrengen. Maar bij een andere transactie, in de zelfde maand tot stand gekomen ${ }^{2}$ ), nemen Sprinckel en de zijnen het risico ter zee op zich van de goederen op heen- en terugreis.

De bewindhebbers bewonderden het voorkoopsysteem met vooruitbetaling niet. In April 1612 lieten ze naar Patani schrijven, dat die methode verder zooveel mogelijk vermeden moest worden, daar men anders te groote kans zou loopen, dat Chineezen „,eenen hoop leuren ende slechte zijde" zouden brengen ${ }^{3}$ ). Coen is het met bewindhebbers eens, en beveelt aan, geen geld op voorkoop te geven, maar den Chineezen te laten zien, dat er wel geld bij kas is, opdat ze niet ontmoedigd zullen worden, maar zich zeker voelen, voor de bestelde artikelen ook inderdaad geld te zullen krijgen ${ }^{4}$ ). Inderdaad schijnt men in Patani sedert deze aanmaningen in hoofdzaak zich van vooruitbetaling te hebben onthouden ${ }^{5}$ ). Dat de handel hierdoor voor de Chineezen minder aantrekkelijk werd, spreekt vanzelf. Want wanneer ze al gezien hadden, dat er genoeg geld bij kas was, wie stond hun er voor in, dat dit het volgende jaar, bij hun terugkomst, nog zoo zou zijn ? En als bij het sluiten van den koop gerekend was op toekomstige geldzendingen met Nederlandsche schepen, wat moesten dan de Chineezen beginnen, indien deze schepen te laat arriveerden ?

1) De copie-cedule, genoemd in noot 2 van p. 132 .

2) Copie-cedule van Teko, Patani, 14 Mei 1608.

3) Brief uit naam der beww. aan Peter Segers te Patani, of opvolger, Amsterdam, 28 April 1612.

4) J. P. Coen aan beww. te Amst., Bantam, 1 Jan. 1614 (Col. Coen I, p. 1 v.).

5) In een copiebrief van Gerrit Frederiksz. Druyff aan beww., Patani, 1 Nov. 1618, verklaart schrijver, dat men met eenige Chineezen voorkoop heeft gemakkt, in "scriptus" (d.i. dus op contract), zonder hun geld op de hand te geven. Vgl. p. 102. 
Buitendien brachten hun reizen naar Patani toch al groote nadeelen mee. Hendrik Janssen doet hiervan een boekje open in $\left.1616^{1}\right)$ : de Chineezen moeten gedoogen, zoo schrijft hij, dat de mandarijnen met geweld uit de jonken doen halen, wat ze noodig hebben; ze betalen daarvoor de Chineezen met olifantstanden, peper en andere waren, die in China dienstig zijn, maar brengen die den Chineezen $1 / 3$ hooger in rekening dan aan andere koopers, terwijl ze, wat ze van hen koopen, met $1 / 4$ minder betalen dan wat het hun in China gekost heeft. Verder moeten ze per baar peper een uitvoerrecht van $61 / 2$ reaal van achten betalen, terwijl den Hollanders maar $13 / 4$ in rekening wordt gebracht. Een betere toestand werd weliswaar, gelijk we zagen, aanvankelijk teweeggebracht door de stichting van ons kantoor in Sangora, totdat ook daar het bederf kwam, en willekeur er de plaats van goede handelsgewoonten innam ${ }^{2}$ ).

De artikelen, die wij in Patani van de Chineezen kochten, konden we op verschillende wijzen betalen: met geld of met goederen. Op het eerste waren de Chineezen zelf het meest gesteld. Contant geld, zoo schrijft Hendrik Janssen in $1614^{3}$ ), ,is den rechten treckplaester van de Chynneesen". Maar niet altijd was dit in voldoende mate beschikbaar, en bovendien: door goederen aan hen kwijt te raken deed men dubbele zaken, al moge het dan waar zijn, dat men met prijs en kwaliteit dier goederen niet het onderste uit de kan moest trachten te krijgen, als het om een goede zijde- of porseleininkoop te doen was. Onder de artikelen, die de Chineezen in Patani van de onzen begeerden, behoorden in de eerste plaats sandelhout ${ }^{4}$ ) en olifantstanden, ivoor dus. Wat het eerste betreft, reeds Van Neck deelt in zijn reisbeschrijving ${ }^{5}$ ) mee, dat de Chineezen geel en wit sandelhout uit Patani plegen te halen. En later krijgt Matelief, als hij naar Indië vertrekt, de instructie mee, dat hij moet trachten te bewerken, dat het sandelhout, dat op 't eiland Timor groeit, zooveel mogelijk naar Patani en Bantam wordt gebracht, opdat de daar komende Chineezen het kunnen koopen ${ }^{6}$ ). Behalve van Timor kwam het hegeerde artikel ook van Solor, en het is in verband met den Patanischen handel, dat op laatstgenoemd eiland een Nederlandsch

1) Copiebrief van Hendrik Janssen aan J. P. Coen, Patani, 25 Oct. 1616.

2) Zie p. 68 en p. 86 .

3) Hendrik Janssen aan beww. te Amst., Patani, 20 Oct. 1614.

4) Zie p. 4 noot 5 .

5) Reisverhaal van Jacob van Neck voor beww., 28 Juni 1600-15 Juli 1603.

6) De kopie van 't verzeilen van Matelief's vloot, bedoeld op p. 28 noot 3 . 
kantoor werd opgericht, nadat het in 1613 op de Portugeezen was veroverd $^{1}$ ).

Ook de olifantstanden werden bij Van Neck's komst door de Chineezen reeds in Patani gezocht ${ }^{2}$ ). In 't algemeen was dit artikel echter niet zoo begeerd als het sandelhout, al schijnt er ook tot in 't laatst van het bestaan van onze factorij geregeld in gehandeld te zijn.

Van minder beteekenis waren tal van andere artikelen, als kruidnagelen, spiegels en glazen, enz.

Eén artikel was er verder nog, waarvan we den Chineezen zoo weinig mogelijk gunden, namelijk de peper. Ten opzichte hiervan heerschte felle concurrentie: beide partijen trachtten het van de inlanders los te krijgen. Onze macht reikte in geenen deele zoo ver, dat we de inlanders konden verhinderen, peper aan de Chineezen te leveren; daarom was de aangewezen weg, te zorgen, dat men met inkoopen vóór was, en er voor den concurrent niets overbleef. Maar niet altijd waren daarvoor de noodige middelen in kas. Vandaar, dat sedert 1617 een nieuwe politiek door Coen geïnaugureerd werd, namelijk die van geweld, en wel niet tegenover de inlanders maar tegen de Chineezen, die peper hadden gekocht en daarmee naar ' $t$ Noorden wilden vertrekken. Aan Hendrik Janssen in Patani draagt hij op, uit de jonken, wanneer ze gekomen zijn ,,buyten limite van de coningen, onse vrienden", al de peper te lichten, die hij kan, en daarvoor alleen den inkoopsprijs met de erop gemaakte onkosten te vergoeden, indien die inkoopsprijs namelijk niet te hoog geoordeeld werd. Voor deze taak zou het schip de Galjas ${ }^{3}$ ) gebruikt moeten worden ${ }^{4}$ ).

Heeren XVII keurden deze politiek echter niet zonder meer goed: zij eischten van Coen nadere opgaaf van de redenen, die tot zijn kras besluit geleid hadden; verder moest hij voorloopig eenige verzachting of wijziging in de gegeven opdrachten brengen, opdat men eventueele zwarigheden in Indië zou vermijden ${ }^{5}$ ). Deze opdracht schijnt inderdaad eenige verbetering voor de Chineezen te hebben uitgewerkt. In een brief, gedateerd 8 Maart 1620, schrijft Druyff aan

1) Elias II, p. 16 v.

2) 't Reisverhaal, genoemd in noot 5 pag. 134.

3) Zie p. 83.

4) Copiebrief van J. P. Coen aan Hendrik Janssen te Patani, 17 April 1617 (Col. Coen II, p. 226 v.).

5) Res. der XVII in hun vergadering van 8 Mei 1618. 
Coen ${ }^{1}$ ), dat hij door middel van het jacht, waarover hij beschikt ${ }^{2}$ ), tot de komst der Nederlandsche schepen op de Chineezen zoodanige pressie hoopt uit te oefenen, dat ze geen peper boven den door de Hollanders besteden prijs zullen durven koopen. In ieder geval dus een eenigszins minder krasse maatregel. Coen tracht verder, de Chineezen naar Jacatra te lokken, waar hij meer en meer den handel wil concentreeren. Druyff moet hun daarom zeggen, dat ze in Jacatra peper in overvloed zullen kunnen koopen ${ }^{3}$ ). Dat de Hollanders daar de markt beheerschen, behoeft er natuurlijk niet bij te worden gezegd! Later echter, toen het kantoor van Patani werd opgeheven ${ }^{4}$ ), vond Coen blijkbaar de meest drastische maatregelen weer gewenscht en gelastte hij weer, desnoods met geweld de peper uit de jonken te lichten ${ }^{5}$ ).

Niet alleen met de komende en gaande Chineezen uit China hadden onze voorouders te maken: ook de stad Patani zelf bevatte, zooals we in het begin zagen, onder haar bevolking een belangrijk Chineesch element ${ }^{6}$ ), dat met inbegrip van de halfbloeds of "Mestisos”, zooals Roelof Roelofsz zich uitdrukt, ongeveer even talrijk, zoo niet talrijker was dan het oorspronkelijke Maleisch-Mohammedaansche. Zij dreven zeehandel op allerlei streken, niet slechts op 't nabij gelegen Bordelon en Ligor, maar ook op Pahang, Johor, Siam, Cambodja en Soekadana, ja zelfs op Banjermasin, Bantam en Grissee ${ }^{7}$ ). Van Neck spreekt van Chineesche kooplieden, in Patani gevestigd, welke niet alleen daar een gezin hebben, maar ook ,in Chinceo ${ }^{8}$ ), van waer sy meest syn, ende over en weder varen, soo dat waer dat sy comen huys,, wyf, ende kinderen vinden" ${ }^{9}$ ). Maar ook als handwerkslieden waren, zooals we boven zagen, de Chineezen van belang. Het interessantst is op dit gebied de zijdenijverheid, d.w.z. het maken

1) Gerrit Frederiksz. Druyff aan J. P. Coen te Jacatra, Patani, 8 Mt. 1620.

2) Dit is dus blijkbaar 't jacht Klein Hollandia, zie p. 100.

3) Copiebrief van J. P. Coen aan G. F. Druyff te Patani, Jacatra, 15 Mei 1620 (Col. Coen II, p. 707 v.).

4) Zie hoofdstuk VIII.

5) Vgl. b.v. Copie-instructie van J. P. Coen voor Jacques Colijn Jansz., visitateur van de kantoren Patani enz., Jacatra, 6 Aug. 1621 (Col. Coen III, p. 70 v.); Copie-instructie van J. P. Coen voor Gerrit Frederiksz. Druyff, gecommitteerd naar Palembang enz., Batavia, 1 Mei 1622 (Col. Coen III, p. 167 v.).

6) Zie p. 3. Ook de in hoofdstuk I genoemde rentmeester Dato Sirinara (p. 6) was een Chinees.

7) Roelof Roelofsz (in Begin ende Voortgangh I), p. 17.

8) Zie over Chincheau p. 118 v.

9) Reisverhaal van Van Neck voor beww., 28 Juni 1600-15 Juli 1603. 
van, naar 't schijnt vooral geborduurde, zijden stoffen uit de in Patani aangebrachte zijde. „Men maect hier ooc veel costelycke cleetgens, die in Banda en Moluccos wel getrocken syn", aldus vinden we reeds in de meermalen genoemde informatie voor Van der Hagen vermeld ${ }^{1}$ ). Wat kon voor de Hollanders welkomer zijn? De komst der Chineesche jonken was onzeker; als nu in Patani zelf de gewenschte weefsels konden worden verkregen, stond men daar veel onafhankelijker, en had men geregeld emplooi voor het kapitaal. Ook kon men er beter invloed op de productie uitoefenen. In October. 1610 bericht Victor Sprinckel ${ }^{2}$ ), dat hij gedurende reeds meer dan twee jaren 16 tot 18 Chineezen aan ' $t$ werk gehouden heeft om aan onze factorij te leveren ${ }^{3}$ ); „cussebladeren, rabatten van ledicanten ofte schoustenen", verder ,"gestiche ${ }^{4}$ ) als opgenayde deeckens op diversche couleuren van armosynen" waren door deze Chineezen gemaakt. De bewindhebbers echter waren met deze producten van de Patanische nijverheid niet bijzonder ingenomen. Zij verklaarden nadrukkelijk, geen Patanische borduurwerken meer te begeeren, daar deze geen winst opleverden; verder waren de ook gezonden ,,sargien ofte bedecleeden" ") zeer slecht geborduurd en meest maar met vloszijde bestikt, niet te vergelijken met het borduurwerk, dat in China werd vervaardigd $\left.{ }^{6}\right)$.

In de zooeven aangehaalde informatie voor Van der Hagen werd, zooals we zagen, ook over Banda en de Molukken gesproken als afzetgebied voor Patanische weefsels. Inderdaad hebben de Nederlanders zich ook aan deze beide mogelijkheden gelegen laten liggen ${ }^{7}$ ). En verder is er in 1607 en 1608 overleg gevoerd tusschen Victor

1) Zie Rouffaer en Juynboll I, bijlage III.

2) Copiebrief van Victor Sprinckel aan beww. kamer Delft, Patani, 31 Oct. 1610.

3) Een soortgelijke toestand dus als in het textielgebied van Koromandel (vgl. mijn proefschrift: De vestiging etc.), waar de Nederlanders ook wel als werkgevers optraden.

4) Lees : gestikte.

5) Lees : beddecleeden.

B) Copiebrief uit naam der beww. aan Peter Segers in Patani, Amsterdam, 17 Dec. 1611; brief uit naam der beww. aan Peter Segers te Patani of opvolger, Amsterdam, 28 April 1612.

7) 30 Augustus 1607 schrijft Hendrik Janssen blijkens zijn copieboek uit Patani aan Hendrik van Bergel op Banda, dat hij geen Patanische kleedjes voor hem heeft kunnen koopen, en stelt hij de vraag, of die voor 't volgende jaar noodig zijn. En in een copie-factuur d.d. 30 Oct. 1616 van de goederen, door Hendrik Janssen gescheept in 't schip de Galjas (vgl. p. 82 v.) treffen we aan 60 stuks Patanische kleeden, voor de Molukken bestemd, als barat meras ('t eerste 
Sprinckel en Abraham van den Broecke ${ }^{1}$ ) over het ten verkoop zenden van kleedjes, in Patani en Bordelon gemaakt, naar Johor; de conclusie van dit overleg was echter, dat er in Johor geen loonende prijzen voor gemaakt zouden kunnen worden ${ }^{2}$ ). In 't algemeen gesproken schijnen dus de Patanische weefsels veel minder ,getrokken” geweest te zijn dan de uit China aangevoerde. Een laatste vermelding, tevens klacht, erover tref ik aan in twee brieven uit 1620 van Coen aan Druyff, waarin hij schrijft over in 't vorige jaar ingekochte Patanische kleedjes, waarvoor veel te veel was betaald ${ }^{3}$ ).

Maar ook voor andere doeleinden dan de kleedjesindustrie konden de Nederlanders de Chineezen gebruiken. We zagen reeds boven ${ }^{4}$ ), hoe Hendrik Janssen, als hij het bestuur der kantoren Patani en Sangora bedreigd voelt, denkt aan 't gebruik o.a. van Chineezen, teneinde het beheer der beide factorijen zoo weinig mogelijk kostbaar te doen zijn. En wanneer er op een of ander schip te weinig menschen aanwezig waren om het te regeeren, was ook Chineesche hulp voor dit doel zeer welkom. Toen b.v. 31 October 1613 het schip de Hoop na een langen zwerftocht in desolaten toestand te Patani arriveerde ${ }^{5}$ ), werden er aldaar meer dan twintig Chineezen tot assistentie op gesteld $\left.^{6}\right)$. En ook als scheepstimmerlieden waren ze bruikbaar : het jacht Klein Hollandia, dat 2 Juni 1619 uit Jacatra naar de bocht van Patani werd gezonden ${ }^{7}$ ), werd daarna in Sangora door Chineesche timmer-

waarsch. = bourat: weefsel van een losgespannen zijden ketting en een inslag van grove wol - vgl. L. v. Nierop, p. 25 noot 1 -, 't tweede : Mal. merah: rood), dittos ytam ('t laatste woord Mal. itam = zwart), kinder barat, cleene petaes ungou (peta's = pata's of patta's: geweven doeken van rooden of blauwen effen grond, doch in het middengedeelte versierd door overdwarse strepen - Rouff. en Juynb. I, p. 155 v. en bijl. III, noot 31 - Ungou: verbastering van wungu $=$ oudjavaansche kleurbenaming voor paars? $-\mathrm{R}$. en J., p. $296-$ ), pontjapans (blijkbaar = pautgypau in de inform. voor Van der Hagen: een halfzijden, changeante stof - R. en J. I, bijl. III, noot $68-$ ), en smallekens (eigenlijk een soort linten. Zie verder R. en J. I, bijl. III, noot 66).

1) Zie p. 37.

2) Zie: Copiebrief van Victor Sprinckel naar Johor aan Abraham van den Broecke, Patani, 28 Dec. 1607 (Copieb. V. S.); idem aan Abraham (van den Broecke?), Patani, 1 Mei 1608 (Copieb. V. S.); idem aan Van den Broecke, Patani, 25 Sept. 1608 (Copieb. V. S.).

3) Copiebrief van J. P. Coen aan G. F. Druyff te Patani, Jacatra, 15 Mei 1620 (Col. Coen II, p. 707 v.); idem aan denzelfde, Jacatra, 3 Juli 1620.

4) Zie p. 92 .

5) Zie p. 74.

6) Coen aan beww. te Ainst., Bantam, 1 Jan. 1614 (Col. Coen I, p. 1 v.); Pieter Both aan beww. der O. I. C., Bantam, 1 Jan. 1614.

7) Zie p. 98. 
lieden ,verdubbeld" $\left.{ }^{1}\right)^{2}$ ). En ten slotte nog een andere zeer belangrijke functie: in $1620^{3}$ ) schrijft Gerrit Frederiksz. Druyff over een Chineeschen tolk, die in de loge van Patani in dienst was.

Eén Chinees, waarmee we in Patani in betrekking stonden, verdient nog bijzonder vermeld te worden wegens de vele diensten, welke hij den onzen bewees, namelijk de reeds vroeger genoemde Empo ${ }^{4}$ ). Deze had reeds in dienst gestaan van Jacob Roussel als factor van de Zeeuwsche Compagnie ${ }^{5}$ ), waarna admiraal Van Warwijck hem an zich had verbonden. In diens dienst had hij, gelijk wij zagen, een tocht naar China meegemaakt, waarna hij met den admiraal in Holland geweest moet zijn. Hij heeft verder, zoo schrijft hij, den Nederlanders diensten bewezen met 't leveren van vivres en andere behoeften bij ' $t$,,belegghen" van Malakka ${ }^{6}$ ), alsmede bij het aanhalen van Portugeesche schepen. Met de Nederlanders in Patani dreef hij handel: ook trad hij wel als borg op. Hij heeft zelfs den godsdienst van zijn Hollandsche vrienden overgenomen, hetgeen blijkt uit een brief van hem uit $1612^{7}$ ). Hij richt zich daarin tot bewindhebbers van Holland en Zeeland om eindelijk betaling te ontvangen van 2000 realen van achten, die hem nog verschuldigd zijn wegens een peperinkoop, door hem op last van Van Warwijck gedaan. Zijn Christendom geeft hem goed vertrouwen, ,want ick niet en dencke, Uwe $E$. begeren imanden van herwaerts over, ende princepalick een Cristi, als ick nu door Godes genade ende uwe E. ende $\mathrm{E}$. dienaers vermaning gewoorden ben, bij de selve uwe dienaers soude vercort oft verongelijckt wordden". Hij schrijft dan verder, dat het, wegens de kwellingen, door de mandarijnen in Patani den Chineezen aangedaan, in zijn voornemen ligt, met zijn jonk in gezelschap van het Nederlandsche jacht ${ }^{8}$ ) uit Patani te vertrekken; zijn

1) Verdubbelen: een huid van planken van onderen af tot op een bepaalde hoogte over de schepen trekken.

2) Gerrit Frederiksz. Druyff aan J. P. Coen te Jacatra, Patani, 8 Mt. 1620 ; Jan van Hasel aan J. P. Coen te Jacatra, Sangora, 4 Oct. 1620.

3) Gerrit Frederiksz. Druyff aan J. P. Coen, Patani, 4 Nov. 1620.

4) Ook als Empau, Emphcu, Imphou, Imphouw, Impon en Emphoijim voorkomende. Vgl. over hem p. 22, 23.

5) Vgl. p. 9 noot 4.

6) Indien dit sloeg op het beleg door Matelief (zie De Jonge III, p. 48 v.) had Empo, met Warwijck naar patria gegaan, hier niet bij kunnen zijn; misschien slaat zijn zinspeling op een dergelijk plan van Verhoeff (op. cit. III, p. 79).

7) Emphou aan beww. van Holland en Zeeland, Patani, 15 Oct. 1612.

8) Dit is dus het jacht Enkhuizen geweest (zie p. 66). De jonk is inderdaad in gezelschap van de Enkhuizen vertrokken (Moreland, p. 82). 
doel is, Amboina, de Molukken en Banda te bezoeken, om daar provisie voor de forten te brengen, zoo mogelijk eenig profijt te doen, en te trachten, in die streken in zijn levensonderhoud te voorzien. Lang heeft Empo het na het schrijven van dien brief niet meer gemaakt: in October 1614 wordt hij als overleden vermeld ${ }^{1}$ ). En in het volgende jaar vernemen $w^{2}$ ), dat in Makassar aan de weduwe van Empo 6000 realen zijn uitbetaald, verminderd met datgene, wat deze nog aan 't kantoor Patani schuldig was ${ }^{3}$ ).

Ik mag deze beschouwing over het Chineesche element in Patani niet eindigen zonder er op gewezen te hebben, dat, behalve de Chineesche goederen, ook de Chineezen zelf uit die plaats in den Archipel zeer welkom waren. Tijdens het bewind van Druyff heeft Coen zich herhaaldelijk in dien geest geuit. Zijn schrijven d.d. 2 Juni $1619^{4}$ ) aan genoemden factorijhouder bevat het verzoek, Chineezen te zenden voor Amboina en Batjan, waar volk ontbreekt om hout te hakken en zagen. Ook op Banda is gebrek aan menschen, waardoor de muskaatnoten en de foelie verloren gaan: Druyff moet dus trachten, Patanische Chineezen ervoor te interesseeren, derwaarts te gaan varen om de noten tot hun eigen profijt te plukken: de Compagnie garandeert, ze van hen te koopen voor denzelfden prijs, die ook aan de Bandaneezen en anderen betaald wordt. Mochten de Chineezen niet gezind zijn, zelf het risico te dragen, dan moet Druyff er een goed getal op maandgeld in dienst der Compagnie aannemen, zoo mogelijk tot 200 toe. Ook met vrouw en kinderen zullen de Chineezen welkom zijn. Voorts heeft Coen Chineezen noodig voor het steenen- en pannen-

1) Hendrik Janssen aan beww. te Amst., Patani, 20 Oct. 1614.

2) Copiebrief van J. P. Coen aan Hendrik Janssen, Bantam, 10 Juni 1615 (Col. Coen II, p. 10 v.).

3) Vgl. over Empo behalve het reeds genoemde: Verhaal reis Warwijck, in Begin ende Voortg. I, p. 74; Opgaaf van verkoop van van Hendrik Janssen overgenomen goederen door Victor Sprinckel, Patani, 6 Oct. 1607-25 Sept. 1608; Copie-cedule van schipper Sanguan e.a., Patani, 13 Mei 1608; Copiecedule van Empo, Patani, 22 Mei 1608; Victor Sprinckel aan Lambert (Jacobsz. Heyn?), Patani, 20 Juli 1608; Copiebrief van Victor Sprinckel aan Jacques l'Hermite de Jonge, Patani, 25 Sept. 1608 (Copieboek V. S.); Copiebrief van Victor Sprinckel aan „Cornelis”, Patani, Sept. 1608 (Copieboek V. S.); Copiebrief van Lambert Jacobsz. Heyn aan Victor Sprinckel, Siam, 17 Mt. 1610; idem aan denzelfde, Siam, 20 Sept. 1610; Victor Sprinckel aan Hendrik Janssen te Patani, Bantam (er staat foutief Patany boven), $20 \mathrm{Mt}$. 161人́; Hendrik Janssen aan beww. te Amst., Patani, 25 Oct. 1616; Copiebrief van Victor Sprinckel aan Lambert Jacopssen (Heyn?) (Copieboek V. S.).

4) Copiebrief van J. P. Coen aan Gerrit Frederiksz. Druyff, Jacatra, 2 Juni 1619 (Col. Coen II, p. 555 v.). 
bakken. In een schrijven van de volgende maand ${ }^{1}$ ) verzoekt hij Druyff al weer, per eerste gelegenheid een zoo groot mogelijk antal Chineezen te zenden, mede voor het bevolken van Amboina en Jacatra. En ook daarna nog herhaalt Coen zijn verzoek verschillende malen ${ }^{2}$ ). En dat Druyff zich niet geheel onbetuigd laat, blijkt uit diens schrijven aan Coen d.d. 4 Nov. $1620^{3}$ ). Tot populatie van Jacatra, aldus de schrijver, zend ik $\mathrm{U}^{4}$ ) tusschen cle 40 en 50 Chineezen, alle arbeidslieden, als zagers, timmerlieden, smeden, metselaars en andere. Hij voegt er bij, dat hij hoopt, met de Sampson ${ }^{5}$ ) en de Morgenster ${ }^{6}$ ) nog meer te zenden.

Was en bleef Patani de aangewezen plaats voor den Chineeschen handel? Ziehier een vraag, die in hoofdstuk II reeds meermalen werd aangeroerd. We zagen, dat reeds Matelief een somber oordeel over de kansen van de factorij had ${ }^{7}$ ), en dat verder ook Coen, tijdgenoot van Hendrik Janssen, diens streven om het Patanische kantoor tot een krachtig steunpunt van Compagnie's handel te maken, eenigszins sceptisch beschouwde, ja in 1618 een beslist ongunstig oordeel uitte ${ }^{8}$ ). We weten ook reeds, dat de behandeling, welke de Chineezen in Patani en op den duur ook in Sangora ondervonden, dikwijls verre van aanmoedigend was. Verder was het varen naar Patani voor de Chineezen dikwijls, gelijk. Druyff vóór het aanvaarden van zijn post aldaar erkennen moet, een vrij hachelijke onderneming, ,alsoo niet geerne verde vaeren om den grooten resico ende de swaere bodemerye, die de coopluyden moeten geven, op verre plaetsen te zeylen" ${ }^{9}$ ). Steeds was daarom China zelf het begeerde vestigingsdoel geweest, en telkens maakte men zich weer illusies, in dit rijk, dat voor onzen handel hermetisch gesloten bleef, vasten voet te kunnen krijgen. Bijzonder listig was een plan, door Empo en andere vooraanstaande

1) Copiebrief van J. P. Coen aan G. F. Druyff te Patani, Jacatra, 2 Juli 1619 (Col. Coen II, p. 571 v.).

2) Copiebrief van J. P. Coen aan Gerrit Frederiksz. Druyff te Patani, in 't schip Nieuw Bantam, 3 Mei 1620 (Col. Coen II, p. 702 v.); idem aan G. F. Druyff te Patani, Jacatra, 15 Mei 1620 (Col. Coen II, p. 707 v.); idem aan denzelfde, Jacatra, 3 Juli 1620.

3) Gerrit Frederiksz. Druyff aan J. P. Coen, Patani, 4 Nov. 1620.

4) Hoogstwaarschijnlijk per Zeewolf, zie p. 99 v.

5) Zie p. 99.

6) Zie p. 100 .

7) Zie p. 39.

8) Zie p. 80 v. en 91 .

9) Copiebrief van Gerrit Frederiksz. Druyff aan beww., Patani, 4 Oct. 1618. 
Chineezen aan Hendrik Janssen gesuggereerd: ${ }^{1}$ ) de Hollanders moesten met hun schepen varen naar "Lamquin" ${ }^{2}$ ). Daar bevond zich in den mond van de rivier $^{3}$ ) een stadje, „Tittjuhou" ${ }^{4}$ ) genaamd, 60 à 70 mijlen boven „Chincheeuw” ${ }^{5}$ ). Bij Tittjuhou aangekomen, moesten de Hollanders verklaren, dat ze namens prins Maurits waren gekomen tot het doen van een hofreis naar den ,koning” van China, die resideerde in Paquin ${ }^{6}$ ). Aan dezen moesten ze dan verzoeken, zoodanige ambassade (verbonden met geschenken aan den vorst!) jaarlijks te mogen herhalen. Daar deze hof reizen van 5 tot 6 maanden in beslag zouden nemen, konden dan ondertusschen de voor anker liggende schepen handel drijven, en wel zonder het minste of geringste voor tol of rechten te betalen! Een plan, dat stellig listig was bedacht, maar waarvan ik nooit gelezen heb, dat het tot uitvoering is gekomen.

Wanneer nu de handel op China zelf met geen moeite en list was te verkrijgen, moest men althans trachten, er zoo dicht mogelijk bij te komen, om voor de jonken de reizen zoo weinig mogelijk bezwaarlijk te maken. „Geconsidereert hebbende”, aldus Coen in December $1617^{7}$ ), ,hoe nodich ende dienstich den Chineesen handel de Compagnie sy, als oock dat haer deselvige niet dan door onse faulte gebreeckt, soo is 't, dat, terwyle sulcx in Java noch Patana off daer ontrent nimmermeer wel gelucken can, alsmede datter noch weynich apparentie schijnt te wesen om in China selffs acces te becomen, my goet gedocht heeft, wat naerder by de wercken te loopen ende te onderstaen, wat men in Quinam sal connen doen".

Met dit Quinam wordt Cochinchina bedoeld, d.w.z. wat men in de $17^{\circ}$ eeuw onder Cochinchina verstond: een landstreek, die ongeveer met het tegenwoordige Annam overeenkomt ${ }^{8}$ ). Reeds lang voor Coen's aansporing was daar een zekere activiteit door de Nederlanders getoond. Van Groesbergen, vice-admiraal van Van Neck, was reeds in deze buurt geweest met de schepen Haarlem en

1) Hendrik Janssen aan beww. te Amst., Patani, 25 Oct. 1616; Copiebrief van Hendrik Janssen aan J. P. Coen, Patani, 25 Oct. 1616.

2) Variant „Lainquin”, zal Nanking zijn, vgl. p. 118.

3) Dus de Jang tse kiang.

4) Variant: „Tijtsjuhou”.

5) Vgl. het op p. 119 opgemerkte omtrent Chincheau.

6) Natuurlijk voor Peking.

7) J. P. Coen aan beww., Bantam, 18 Dec. 1617 (Col. Coen I, p. 290 v.).

8) Er heerscht over de begrippen Cochinchina en Quinam overigens ook in de $\mathrm{XVII}^{\circ}$ eeuw wel eenige verwarring: Quinam wordt namelijk ook wel als een plaats in Cochinchina genoemd. 
Leiden ${ }^{1}$ ), en had er, zooals we zagen, 23 man door moord verloren. Dit geschiedde ergens in Cochinchina of in het, ten Zuiden daarvan liggende Champa of Tsi-Ampa. Verder naar 't Noorden zeilende, trachtte Van Groesbergen betrekkingen aan te knoopen met den koning van Tachem $^{2}$ ) door middel van den koopman Jeronimus Wonderaer en den onderkoopman Albert Cornelisz. Ruyll. Hun hofreis leverde niet het geringste practische resultaat op, en Van Groesbergen, tenslotte gewaarschuwd, dat hij opnieuw met een aanslag bedreigd werd, verliet met ongenoegen deze streken, waar hij, gelijk wij zagen, het gunstige getij op China gemist had, en kwam 28 December 1602 in Patani aan ${ }^{3}$ ).

Een nieuwe ramp in Chochinchina geschiedde naar aanleiding van een Engelsche en een Nederlandsche handelspoging van Japan uit in 1614. De gegevens hierover zijn, hoewel van Engelsche zijde menigvuldig, toch onduidelijk en tegenstrijdig. Het zenden van een Engelsche en een Nederlandsche jonk schijnt in verband te hebben gestaan met een voorspoedigen handel, eenige jaren vroeger door zekeren Nederlander "John Joosen" ${ }^{4}$ ) in Cochinchina gedreven. De Engelschen en Nederlanders nu hebben blijkbaar om een of andere reden de verbolgenheid van 't hof opgewekt. We vernemen althans, dat o.a. én de Engelsche koopman Tempest Peacock én de Nederlander Cornelis Claesz. van Toornenburch werden vermoord $\left.{ }^{5}\right)^{6}$ ).

Hierna rustte het plan-Cochinchina een tijd lang. Maar in 1617 werd er weer zeer levendig werk van gemaakt. En geen wonder:

1) Vgl. p. 12 v.

2) Deze plaats is moeilijk te localiseeren. De Jonge plaatst haar op zijn schetskaart van Opkomst II veronderstellenderwijs bij de kust in 't midden van Cochinchina op $\pm 18^{\circ}$ N.B.

3) Vgl. over de poging van Van Groesbergen: De Jonge, Opkomst III, p. 245 v.; Tiele, 4 VI, p. 180; „Discours ende advertentie”, genoemd in noot 3 van p. 10 ; Dr. W. J. M. Buch: De Oost-Indische Compagnie en Quinam, Amsterdam 1929, p. 9 v.

4) Aldus de Engelsche schrijfwijze. We hebben hierin te zien Jan Joosten van Lodenstein. Zie over hem en zijn tocht naar Cochinchina: Wieder, dl. III, p. 28.

5) Een lezing, dat er niet van een moord maar van een ongeval sprake zou zijn (Letters Received V, no 342 en 424) schijnt weinig geloofwaardig.

6) $\mathrm{Zie}$ over deze episode: Buch, p. 12 v.; Moreland, p. 146; Calendar of State Papers, Colonial Series, East Indies, China and Japan, 1513-1616, London 1862, p. LXI, $\mathrm{n}^{\circ}$ 823, idem 1617-1621 $\mathrm{n}^{\circ}$ 273, 275, 277; Lett. Rec. II, $\mathrm{n}^{\circ} 131$, $155,156,157,189^{1}$, idem III, appendix $n^{\circ} \mathrm{V}$, idem IV $\mathrm{n}^{\circ} 339$; idem $\mathrm{V} \mathrm{n}^{\circ} 342$ en 424; Wieder 1.1. Wat Tiele (Eur. 5, II, p. 242 noot 2 zegt, n.1. dat sinds 1614 de Hollanders ook in Cochinchina handelden, zal niet betrekking kunnen hebben op een geregelde vestiging aldaar. 
de koning had, door 't zenden van brieven naar Bordelon en Patani, de onzen zoodanig geanimeerd, zich in zijn land te komen vestigen, hij had zoo aanlokkelijke voorspiegelingen gedaan omtrent de vrijheid, welke de Nederlanders in zijn land zouden genieten, dat de animo voor een nieuwe poging algemeen was. Van Nieuwenroode, die, in Ligor zijnde ${ }^{1}$ ), een brief van den koning van Cochinchina ontvangen had, verklaarde, zich geen betere plaats voor den Chineeschen handel te kunnen voorstellen; de tollen en rechten waren er lager dan elders in Indië, terwijl er allerlei lijftocht in overvloed was te krijgen. En ook Hendrik Janssen koesterde goede verwachtingen. Hij schijnt zich persoonlijk goed op de hoogte gesteld te hebben van de plaatselijke situatie ${ }^{2}$ ), althans zijn opvolger Druyff, eveneens een warm voorstander van vestiging in Cochinchina, noemt Janssen als autoriteit, wanneer hij de voordeelen van het nieuwe beloofde land opsomt. De vestiging, aldus Druyff, zou moeten geschieden bij een prachtig gelegen baai, „Bodba” geheeten ${ }^{3}$ ), besloten tusschen twee toeloopende klippen, met nauwen toegang, maar van binnen ruimte biedende voor honderden schepen. Er was goed water te krijgen, er waren bosschen van ebbenhout, dat beter zou zijn dan dat van Mauritius, de materialen voor het bouwen van een loge zouden er goedkoop zijn. Chineezen zouden zich, gezien ook de vruchtbaarheid van 't land, er bij massa's vestigen, voor een karig loon van zes stuivers per dag zouden ze welken arbeid dan ook met graagte voor de Hollanders willen verrichten; in de toekomst zouden de zelfde Chineezen als belastingobject kunnen worden gebruikt voor de instandhouding van het (te stichten) Nederlandsche fort. Engelschen, Franschen en anderen concurrenten zou men 't verblijf in deze plaats kunnen ontzeggen, terwijl de inwoners, ,seer slechte goede luyden”, geen macht tegen de Nederlanders zouden kunnen doen gelden ${ }^{4}$ ).

Toen Druyff dezen brief aan bewindhebbers van Amsterdam

1) Niet op bezoek van Siam uit, zooals Buch (p. 15) meent; Van Nieuwenroode is factorijhouder in Sangora geweest (zie p. 75, noot 2).

2) Wanneer, is mij onbekend.

3) Dezen naam heb ik niet kunnen identificeeren.

4) Vgl. Buch, p. 15 v.; Van Dijk: Borneo etc., p. 230 noot 3, p. 231 noot 2, p, 347; Copieres. door de raadspersonen van 't kantoor Patani en de schepen Zwarte Leeuw en Galjas, Patani, 26 Mei 1617; Cornelis van Nieuwenroode aan kamer Amst., Ajudhja, 20 Sept. 1617; Copiebrief van Hendrik Janssen aan J. P. Coen te Bantan, Patani, 25 Oct. 1617; J. P. Coen aan beww., Bantam, 18 Dec. 1617 (Col. Coen I, p. 290 v.); Copiebrief van Gerrit Frederiksz. Druyff aan beww., Patani, 4 Oct. 1618; Gerrit Frederiksz. Druyff aan J. P. Coen, Patani, 4 Nov. 1620. 
schreef, was reeds lang door 't centrale bestuur in Indië een begin gemaakt met een hernieuwde poging op Cochinchina, en wel in 1617. We vermeldden reeds boven ${ }^{1}$ ), dat in dat jaar Patani werd bezocht door de schepen Galjas en Zwarte Leeuw, en dat daarbij toen het aanknoopen van betrekkingen met Quinam mede op het program stond. Coen stelde zich voor, dat speciaal de Zwarte Leeuw, na Japan te hebben bezocht, deze betrekkingen ter hand zou nemen, maar ' $t$ mocht ook, al naar omstandigheden, een ander schip zijn. Het noodige kapitaal zou gefourneerd moeten worden door Hendrik Janssen in Patani, aangevuld met wat er nog voor kon worden afgestaan in Japan door Jacques Specx, die zelf mee mocht gaan naar Cochinchina. In Patani of Japan moest een brief aan den koning worden opgesteld, met het verzoek, in diens land te mogen negotieeren; nauwkeurige informatie zou moeten worden genomen naar de wijze, waarop vroeger volk en goed van de Compagnie verongelukt waren; van eventueel achtergebleven goederen moest men zooveel mogelijk in handen zien te krijgen. Groote voorzichtigheid diende betracht te worden bij het water halen, daar de Cochinchinders geenszins te vertrouwen waren! De goederen, die men in Cochinchina zou kunnen verkrijgen, dienden naar 't kantoor van Patani te worden gezonden ${ }^{2}$ ).

Ook van het plan-1617 is echter niets terecht gekomen. Wel werden in Patani 4000 realen van achten in de $Z$ warte Leeuw geladen voor Cochinchina ,tot een inleydinge haerder handelinge aldaer"; op de Chineezen, met welke men er zou handelen, zou het een goeden indruk maken, dat de Nederlanders met de begeerde contanten handel wilden drijven! Den $30^{\text {en }}$ Mei, we zagen het boven $\operatorname{reeds}^{3}$ ), vertrokken de Galjas en de Zwarte Leeuw uit Patani naar Japan. De 4000 realen werden echter door Specx voor den handel op de Molıkken gebruikt. Hij zou echter trachten, de kapitale som van 50000 realen voor Quinam bijeen te krijgen; met de schepen Galjas en Oude Zon zou dan de handel er worden begonnen. Deze schepen zijn echter niet in dit land geweest; naar het schijnt, rezen er moeilijkheden met de bemanning. Coen echter, die goede hoop koesterde, dat ze er een groote lading van de Chineezen zouden weten te verkrijgen

1) Pag. 83.

2) Vgl. Van Dijk: Borneo etc., p. 347 ; Buch, p. 14 v.; Copie-res. van J. P. Coen c.s., Jacatra, 16 April 1617 (Col. Coen III, p. 393 v.); Copiebrief van J. P. Coen aan Jacques Specx in Japan, Jacatra, 23 April 1617 (Col. Coen II, p. 232 v.); Copie-instructie voor de raden van de schepen Zwarte Leeuw en Galjas, Jacatra, 23 April 1617 (Col. Coen II, p. 238 v.).

3) Pag. 83.

Verh. dl. I. 
- hij had hooren verluiden, dat er in Cochinchina veel zijde was aangebracht - , nam maatregelen om ervoor te zorgen, dat niet alles naar Japan zou worden gebracht: toen op 5 April 1618 de Zwarte Leeuw en 't jacht Jacatra van de plaats Jacatra vertrokken ${ }^{1}$ ), ging hiermee de order, dat de Jacatra dadelijk naar Cochinchina door moest varen, om $2 / 3$ van de zijde en zijdewaren naar Jacatra te brengen. Eventueel mocht ook de Zwarte Leeuw dit ${ }^{2 / 3}$ gedeelte gaan halen; als er weinig zijde zou zijn gekocht, moest de Jacatra deze naar Patani brengen, ter overscheping aldaar in de Zwarte Leeuw; beide schepen zouden dan naar Japan kunnen gaan. Ook hier dus weer een zeer soepele instructie.

We weten, dat het jacht Jacatra en de Zwarte Leeuw 11 Mei in Patani aankwamen, en dat het eerstgenoemde nog in dezelfde maand naar Cochinchina vertrok ${ }^{2}$ ). Het werd echter bedrogen in zijn hoop, daar de Galjas en de Oude Zon te vinden, en vertrok naar Japan. Op dezen tocht werd het in den strijd met de Portugeezen vernietigd $\left.{ }^{3}\right)^{4}$ ).

Van nader contact met Cochinchina is dus niet gekomen. Dat de commandeur Jan Dircksz. 't Lam in 1617 in Quinam landde, was volmaakt toevallig: hij was er terecht gekomen op weg van de Molukken naar Japan. Wel verkreeg hij in een haven, op $12^{\circ}$ N.B. gelegen, levensmiddelen, maar hij zetten zijn reis voort zonder dat

1) Pag. 84.

2) Pag. 84 .

3) Pag. 84.

4) Zie over 't voorgaande: Van Dijk: Borneo, p. 230 noot 3, p. 231, 347; Buch, p. 16 v.; Copieresolutiën van de raadspersonen van 't kantoor te Patani en de schepen Zwarte Leeuw en Galjas, Patani, 26 Mei 1617; Cornelis van Nieuwenroode aan de kamer Amsterdam, Ajudhja, 20 Sept. 1617; Copiebrief van Hendrik Janssen aan J. P. Coen te Bantam, Patani, 25 Oct. 1617; Extractbrief aan Gerrit Frederiksz. Druyff, Ajudhja, 28 Dec. 1617; Copiebrief van J. P. Coen aan commandeur 't Lam in de Molukken, Bantam, 30 Dec. 1617 (Col. Coen II, p. 321 v.); Copie-instructie van Jan Dircxen Lam voor Jan Berchoudt, president over de schepen Oude Zon en Galjas, Firando, 30 Dec. 1617; Copie-res. van president en raden, in 't schip Zierikzee voor Bantam, 20 Mt. 1618 (Col. Coen III, p. 429); Copiebrief van J. P. Coen aan Hendrik Janssen te Patani, in 't schip Zierikzee, liggend aan de eilanden van Jacatra, 30 Mt. 1618 (Col. Coen II, p. 360 v.) ; idem aan Specx te Firando, geschreven in 't schip als voren, 30 Mt. 1618 (Col. Coen II, p. 368 v.); J. P. Coen aan beww., Jacatra, 24 Juni 1618 (Col. Coen I, p. 335 v.); Copiebrief van Gerrit Frederiksz. Druyff aan beww., Patani, 4 Oct. 1618; J. P. Coen c.s. aan beww., in 't schip de Oude Zon, liggende voor Mandalique omtrent drie mijlen bij Oosten Japara, 14 Jan. 1619 (Col. Coen I, p. 416 v.); Gerrit Frederiksz. Druyff aan beww. kamer Amst., Patani, 26 Mt. 1619; Copiebrief van J. P. Coen aan Jacques Specx in Japan, Amboina, 4 April 1619 (Col. Coen II, p. 534 v.). 
zijn bezoek blijvende gevolgen had ${ }^{1}$ ). Toch bleef de aandacht der Hooge Regeering op Cochinchina gevestigd. Nog in 1618 ontwikkelde Coen een grootsch plan: het was noodig, zoo schreef hij aan bewindhebbers, een goede vloot van 4 of 5 schepen met een groote som gelds naar Cochinchina te zenden, om daaromtrent op een der eilanden een fort te maken, iets, wat door de Chineezen zeer gaarne gezien zou worden. En ook in 1619 treedt in een schrijven van hem aan Druyff zijn belangstelling in dit handelsgebied weer aan 't licht. Ook in Japan was men toen diligent: een factuur van 31 Januari 1619 omtrent de goederen, door Jacques Specx geladen in 't jacht de Vliegende Bode, tot inkoop van Chineesche goederen in Cochinchina, beloopt in totaal de som van $f$ 175245.4.12 !

In 1620 echter komt bij Coen de ommekeer : voor noodbehulp dient de handel in Cochinchina nog wel behartigd te worden, maar alleen zoo lang Jacatra nog niet genoeg Chineezen trekt; hij hoopt echter welhaast dezen handel "tot Jacatra in soo goeden sleur" te zullen krijgen, ,als oyt in Manilla geweest is". Cochinchina en Patani moesten ook hierom noodzakelijkerwijs bij Jacatra achterstaan, ,alsoo het voor ons tot Jacatra beter gelegen compt ende de zijdewaeren veel eer vandaer naer ' $t$ patrya gesonden connen werden". Coen's houding is echter nog niet volkomen consequent: in Januari 1622 is zijn aandacht op Macao gericht: deze plaats of een andere aan de kust van China zal door ons moeten veroverd en versterkt worden.

Over den Chineeschen handel, van zoo uitnemend belang voor de Compagnie, was het laatste woord nog niet gesproken: nog langen tijd nadat het kantoor in Patani was opgeheven, zou dit vraagstuk de aandacht der Hooge Regeering bezighouden ${ }^{2}$ ).

1) Zie Buch, p. 18.

2) $\mathrm{Zie}$ in 't algemeen: Groeneveldt, en in 't bijzonder over 't voorgaande: Van Dijk: Borneo, p. 348; Buch, p. 18 v.; J. P. Coen aan beww., Jacatra, 26 Juli 1618 (Col. Coen I, p. 356 v.); Copie-factuur der goederen, door Jacques Specx geladen in 't jacht de Vliegende Bode, Firando, 31 Jan. 1619; Copiebrief van J. P. Coen aan Gerrit Frederiksz. Druyff, Jacatra, 2 Juni 1619 (Col. Coen II, p. 555 v.); idem aan Jacques Specx te Firando, in 't schip Nieuw Bantam, onder Poulo Panjangh, 28 Febr. 1620 (Col. Coen II, p. 652 v.); J. P. Coen c.s. aan beww., Jacatra, 26 Oct. 1620 (Col. Coen I, p. 585 v.); Copie-memorie van J. P. Coen voor Pieter de Carpentier en Jacob Dedel te Jacatra, Jacatra, 12 Jan. 1621 (Col. Coen III, p. 5 v.); Pieter de Carpentier c.s. aan beww. Amst., Jacatra, 9 Juli 1621 ; J. P. Coen c.s. aan beww., Batavia, 21 Jan. 1622 (Col. Coen I, p. 688 v.); Monsterrol van alle schepen en jachten, op 26 Oct. 1620 in Indië. 


\section{VIERDE HOOFDSTUK.}

\section{De peperhandel.}

Was de Chineesche handel de eigenlijke raison d'être van de factorij te Patani, daarop volgde als tweede belang de peperinkoop. Hierbij heeft deze plaats nooit een ook maar eenigermate unieke rol gespeeld: voor den peperhandel dienden ook tal van andere plaatsen. Het verdient echter wederom vermelding, dat, in tegenstelling met de zijde, de peper een eigen product van het land was, en dat dit gewas, zooals we gezien hebben, bij de komst der eerste schepen onder Van Neck hoofdzaak was geweest ${ }^{1}$ ). Ook bij den peperinkoop werd weder veel van het beleid der leggers geëischt, niet zoozeer op 't punt van warenkennis - „peperspecialisten” zijn mij niet bekend - als wel bij het onderhandelen met de inlanders. De handel in peper was namelijk allesbehalve een vrij bedrijf, en de leveranciers waren niet vrij in ' $t$ bepalen van hun prijzen. Van overheidswege werd getracht, deze zoo hoog mogelijk te houden. Dit mag ten deele in 't belang der inlandsche kooplui gedaan zijn, het gebeurde stellig nog meer wegens het voordeel, dat de regeering bij een hoogen prijs had, b.v. ten opzichte van de tolheffing. Bij de komst van onze eerste schepen moest men dan ook reeds dadelijk merken, dat met een of meer aanzienlijken een moeizaam spel van loven en bieden noodig was, voordat eindelijk de prijs voor den ,vrijen” handel vastgesteld werd ${ }^{2}$ ). Het koopen werd dan aan de Nederlanders vrijgegeven, waarbij het gewoonte geweest schijnt te zijn, dat men bij gongslag de verkoopers naar de loge deed komen ${ }^{3}$ ). Het kon natuurlijk ook gebeuren, dat de factorijhouders bij het peperkoopen van in Patani gevestigde tusschenpersonen gebruik maakten. Zoo heeft de Chinees Empo ${ }^{4}$ ) daarvoor

1) Zie hoofdstuk $I$.

2) $\mathrm{Bij}$ den tocht van Van Neck kwamen de sabandar en de rentmeester Dato Sirinara er bij te pas (zie p. 5 v.); de laatste speelde wederom een groote rol bij de komst van Cornelis Pietersz (zie p. 18 v.).

3) Copiebrief van Victor Sprinckel aan Abraham (van den Broecke?), Patani, 1 Mei 1608 (Copieb. V. S.).

4) Zie p. 139 v. 
wel zijn hulp verleend ${ }^{1}$ ). Lastig werd het echter, wanneer de hebzuchtige mandarijnen trachtten, zelf alles op te koopen ${ }^{2}$ ).

Met de betaling van de peper was men er nog niet. Afgezien van de schenkages, waarmee men de inlandsche autoriteiten eerst gunstig te stemmen had, en die naar gelang van omstandigheden natuurlijk zeer variabel konden zijn, had men tol en waaggeld te betalen. Wat den tol betreft, dezen vinden we steeds opgegeven ter waarde van $5 \%$ op de ingekochte peper ${ }^{3}$ ). In 1607 werd men gedwongen, boven den gewonen tol nog twee maes goud (gelijkgesteld met $1 \frac{1}{2}$ reaal van achten) meer te betalen, maar in Mei 1608 vernemen we, dat deze extra-heffing weer afgeschaft is $\left.{ }^{4}\right) . \mathrm{Er}$ is in 1608 zelfs hoop geweest, dat men den tol met $1 \frac{1}{2}$, ja misschien zelfs $2 \%$ zou kunnen verminderen ${ }^{5}$ ), maar dat dit inderdaad geschied is, bleek mij nergens; in 1612 wordt weer van den $5 \%$-tol gesproken. Het waaggeld bedroeg 1 maes $^{6}$ ) voor iedere baar ${ }^{7}$ ), althans volgens de weinige gegevens, die ik hierover vond ${ }^{8}$ ).

In Sangora was de toestand gunstiger dan in Patani, zooals immers ook onze handel met de Chineezen aldaar op gunstiger basis gevestigd werd. Druyff schreef in een brief d.d. 8 Maart 1620 aan Jan Pietersz. Coen, dat de koning van Sangora de peper tol- en waagvrij liet verschepen. En waar in den regel de inlandsche potentaten neiging vertoonden, gaandeweg hun eischen te verzwaren, mogen we aannemen, dat deze gunstige omstandigheid reeds van 't begin af bestaan heeft.

Voor het inkoopen van peper kon men natuurlijk goud of de alom gezochte realen van achten gebruiken. Een groot gemak was echter,

1) Zie den extract-brief van Van den Broecke, bedoeld op p. 23 noot 2.

2) Copie-missive van Jacques l'Hermite de Jonge aan beww., Bantam, 28 Jan. 1608.

3) Zie ook p. 6 en 19. Heeres: Corp. Dipl. I, p. 16, geeft $8 \%$, maar dit zal wel op vergissing berusten, daar Van Dam II I, p. 324, zinspelende op de zelfde overeenkomst (die met Van Neck), ook $5 \%$ opgeeft.

4) Copiebrief van Hendrik Janssen aan Jan Willemss. Verschoor te Bantam, Patani, 29 Oct. 1607 (Copieb. H. J.); Copiebrief van Victor Sprinckel aan Abraham (van den Broecke?), Patani, 1 Mei 1608 (Copieb. V. S.).

5) Copiebrief van Victor Sprinckel aan Van den Broecke, Patani, 25 Sept. 1608 (Copieboek V. S.); idem aan Jacques l'Hermite de Jonge te Bantam, Patani, 25 Sept. 1608 (Copieboek V. S.).

6) $\mathrm{Zie}$ boven op deze p. In 1603 wordt 1 maes op $2 / 3$ reaal berekend. Zie p. 19.

7) Vgl. de gegevens van noot 6.

8) Reis Van Warwijck (in Begin ende Voortg. I), p. 45; Copiebrief van Victor Sprinckel aan Abraham (van den Broecke?), Patani, 1 Mei 1608 (Copieb. V. S.) ; Victor Sprinckel aan beww. te Amst., Patani, 25 Sept. 1608. 
dat men bovendien met zilver kon betalen. Reeds boven is meegedeeld, dat Japan dit metaal leverde, maar dat men tijdens de tweede bestuursperiode van Hendrik Janssen er in Patani moeilijk de Chineezen mee tevreden kon stellen bij inkoop van zijde of porselein, ja, dat ook door de Maleiers het Japansche zilver slechts tegen een te lage waarde werd aangenomen ${ }^{1}$ ). Voor den peperinkoop echter werd het in lateren tijd gebruikt: een paar gegevens uit $1619^{2}$ ) leeren ons, hoe men toen altijd het Japansche zilver wel kwijt kon raken bij de munt in Bordelon of Ligor. Men kreeg het dan ingewisseld tegen plaatselijke munt, die weliswaar een zeer slechte zilverkwaliteit had, maar toch voor het door ons angegeven doel geschikt was.

Voor de verpakking van peper werden veelal zakken gebruikt, die $1 / 6$ deel van een baar konden bevatten ${ }^{3}$ ), dus ruim 63 pond $^{4}$ ).

$\mathrm{Bij}$ de peperleveranties werd door de Nederlandsche kooplieden zeer gelet op de zuiverheid: maar al te vaak namelijk bevond zich in het product een vrij groot quantum stof en ,ampa”, met welke laatste uitdrukking, die afval beteekent ${ }^{5}$ ), de overbodige plantaardige bestanddeelen van de peperplant moeten bedoeld zijn, het ,stroo", zooals ook wel gezegd werd. We zagen, dat reeds Van Neck met dit bezwaar te maken $\mathrm{kreeg}^{6}$ ), en eischte, dat de inlanders het ,onsuijver goet" zouden zuiveren, d.i. wannen (ziften, garbuleeren), ook, dat, toen hij dit later op eigen kosten ging doen, hij wel $6 \%$ aan gewicht verloor $\left.{ }^{7}\right)^{8}$ ). Des te noodzakelijker was het dus in 't vervolg om, teneinde ballast in de schepen te voorkomen, de ontvangen peper, die door de inlanders niet of slecht gewand was, zelf te zuiveren of te herwannen. In verband met dit onderwerp ontleenen we een zeer interessant gegeven over de in Patani gevolgde methoden aan een

1) Zie p. 89 v.

2) Gerrit Frederiksz. Druyff aan beww. kamer Amst., Patani, 26 Mt. 1619; Copiebrief van Cornelis van Nieuwenroode aan Jacques Specx in Firando, Ajudhja, 31 Mei 1619.

3) Hendrik Janssen aan beww. te Amst., Patani, 25 Oct. 1616; Copiebrief van J. P. Coen aan Carpentier, in de Mauritius tusschen Craketouw en Dwars in de Wech, 9 Febr. 1623 (Col. Coen III, p. 308 v.).

4) Zie p. 6.

5) Encycl. van Ned.-Indië i.v. ampas.

6) Pag. $6 \mathrm{v}$.

7) Pag. 8.

8) De Patanische peper heeft wegens deze onzuiverheid blijkbaar een slechte reputatie gehad: in December 1615 schrijft de Engelschman Ralph Coppindall in Firando: „Bantam pepper is more in request than Patania pepper, for that those which have made trial say Patania pepper, though it be fair to the eye, is most part husk" (Lett. Rec. III, $\mathrm{n}^{\circ}$ 317). 
copie-brief aan Coen, geschreven op 10 April 1618 door bewindhebbers der kamer van Amsterdam $\left.{ }^{1}\right)$. $\mathrm{Zij}$ hebben het daarin over peper, waaronder zeer veel licht en bol goed ${ }^{2}$ ) loopt, en die dan door 't lossen, laden en verder hanteeren voor een groot deel tot stof en poeder wordt. $\mathrm{Zij}$ vervolgen daarop, gehoord te hebben van een soort garbuleermolen, die in Patani in gebruik was, met breede bladen van ,gehele ${ }^{3}$ ) dunne plancken”, boven welke vleugels zich een vierkante bak bevond, waar de peper ingegoten werd; onder de vleugels daarentegen was een soort goot, waardoor de peper naar beneden viel, zóó, dat eerst door den wind van de ronddraaiende vleugels de lichte peper, die ongewenscht was, was weggewaaid van de zware, welke dan alleen behouden bleef. Bewindhebbers vinden dan, dat deze Patanische garbuleermolen of andere instrumenten voor het zelfde doel ook elders zouden dienen toegepast te worden.

Bij de peper, welke in de bocht van Patani werd ingekocht, dient onderscheid te worden gemaakt tusschen de daar gekweekte en de van elders daarheen geimporteerde. Wat de eerste betreft, kunnen we uit enkele gegevens afleiden, wanneer zij ,viel”, d.w.z. leverbaar werd. Brieven van Victor Sprinkel uit 1608 aan bewindhebbers te Amsterdam en aan Jacques l'Hermite te Bantam ${ }^{4}$ ) wijzen erop, dat eind October de pepermoesson ${ }^{5}$ ) aanstaande is. In strijd hiermee schijnt het, wanneer in een instructie aan den opperkoopman Philips Lucasz uit $1623^{6}$ ) verklaard wordt, dat men heeft vernomen, dat in de streken van Patani in Mei de meeste peper te krijgen was. Tegenspraak behoeft hier echter niet te zijn : ook in den Oostindischen archipel zijn, afgezien dan van zeer dicht bij den evenaar gelegen streken, gewoonlijk twee peperoogsten, de eene tusschen October en Maart, de andere tusschen April en September ${ }^{7}$ ).

Het spreekt wel vanzelf, dat de komst der Nederlanders in Patani op den aanplant stimuleerend werkte. Reeds Van Neck geeft hier hoog van op: „Dewyl wylieden daer beginnen te varen, hebben sy die menichvuldich voort geplant, soo dat ongetwryffelt binnen drie ofte

1) Vandaar; bij Col. Coen IV, p. 391 v.

2) Waarsch. peperhuid zonder korrel er in.

3) Is dus $=$ heel.

4) Victor Sprinckel aan beww. te Amst., Patani, 25 Sept. 1608, Victor Sprinckel aan Jacques l'Hermite de Jonge te Bantam, Patani, 27 Oct. 1608.

5) Hier dus : peperseizoen.

6) Copie-instructie voor Philips Lucasz. en den raad van de Zwarte Beer, de Hazewind en de Vos, fort Batavia, 3 April 1623.

7) Encycl. van Ned. Indië i.v. peper. 
vier jaren het gewas daer seer vermeerderen sal"1). Ook uit latere tijden komen berichten over nieuwen aanplant tot ons ${ }^{2}$ ). Natuurlijk deden de Hollanders wat ze konden, om dezen aanplant met alle krachten te bevorderen. Op 4 November 1620 schrijft Druyff aan Coen, uit Sangora bericht te hebben ontvangen, dat Van $\mathrm{Hasel}^{3}$ ) het binnenland in zou trekken om te zien, wat er in dien moesson was te doen in de peper, die zeer aanrijpte ${ }^{4}$ ). Nog een stap verder zou al tot eigen pepercultures geleid hebben! Daarvan heb ik echter nergens sporen aangetroffen. Maar zelfs in 1621, als Coen reeds de voorbereidingen treft tot het opheffen der kantoren in de bocht van Patani, geeft hij toch meteen order, de inlanders met nadruk op te wekken om met den aanplant van peper door te gaan ${ }^{5}$ ).

De hoeveelheid peper uit de streken van Patani, die vooral uit de buurt van Ligor afkomstig schijnt te zijn geweest, was echter gering in vergelijking met wat van elders werd aangevoerd ${ }^{6}$ ). Patani was namelijk meer een peperhandelscentrum dan peperproductieplaats : we hebben hier al eens op gezinspeeld ${ }^{7}$ ). Met hun jonken voeren de inwoners naar allerlei andere plaatsen om de begeerde handelswaar te halen: in de eerste plaats naar Jambi, maar verder ook naar Indragiri, naar Kampar ${ }^{8}$ ) en naar Pahang ${ }^{9}$ ). Ook blijkt ons uit gegevens van 1608, dat uit Queda, aan de Westkust van 't schiereiland van Malakka, wel peper te Patani aangevoerd is ${ }^{10}$ ). Ja, ook uit Johor werd door de inwoners peper in Patani aangebracht ${ }^{11}$ ), en we be-

1) Reisverhaal van Jacob van Neck voor Bewindhebbers, 28 Juni 1600 15 Juli 1603.

2) Copiebrief van J. P. Coen aan Hendrik Janssen te Patani, in 't schip Zierikzee, liggende aan de eilanden van Jacatra, $30 \mathrm{Mt}$. 1618 (Col. Coen II, p. 360 v.); idem aan G. F. Druyff te Patani, Jacatra, 15 Mei 1620 (Col. Coen II, p. 707 v.) ; Gerrit Frederiksz. Druyff aan J. P. Coen, Patani, 4 Nov. 1620.

3) Zie p. 106.

4) $\mathrm{Zie}$ het laatste in noot 2 genoemde stuk.

5) Copie-instructie van J. P. Coen voor Jacques Colijn Jansz., gedestineerd tot de visite van de kantoren in Patani etc.., Jacatra, 6 Aug. 1621 (Col. Coen III, p. 70 v.).

6) Zie p. 4.

7) Vgl. p. 6 v.

8) Hiermee zal wel bedoeld zijn het gebied aan de aldus genaamde rivier aan Sumatra's Oostkust.

9) Zie: Cornelis van Nieuwenroode aan de kamer Amst., Ajudhja, 20 Sept. 1617.

10) Copiebrief van Victor Sprinckel (aan?), Patani, 25 Mt. 1608 (Copieb. V. S.); idem aan Van den Broecke, Patani, 25 Sept. 1608 (Copieb. V. S.); idem aan Jacques l'Hermite de Jonge te Bantam, Patani, 25 Sept. 1608 (Copieb. V. S.).

11) Resolutie van 't college van de Griffioen en de Roode Leeuw met Pijlen, bij 't eiland Polo Tijmon, 1 Dec. 1609. 
grijpen de ontevredenheid van Matelief, die immers al zeer weinig voor het aanhouden der factorij in laatstgenoemde plaats gevoelde ${ }^{1}$ ), dat deze peper daar duurder moest worden ingekocht dan in Johor zelf : de Nederlanders joegen aldus ten onrechte den Pataniërs de negotie toe, welke den onzen zooveel tol afnamen als ze wilden ${ }^{2}$ )!

Wat is dan, zoo vragen we ons af, de reden van Patani's reputatie als peperhandelsplaats? Deze zal wel zijn, dat de Chineezen nu eenmaal de vaart op deze plaats hadden, waar ze hun zijde en andere waren aanbrachten, om dan vooral peper als lading op de terugreis mee te nemen; dat de Compagnie het laatste zooveel mogelijk trachtte te verhinderen, is reeds vermeld ${ }^{3}$ ).

Het is waar, dat de Patanische peper beter van kwaliteit was dan de soorten, die daar werden aangevoerd uit Jambi en Indragiri, tengevolge waarvan de prijs ook evenredig hooger was. - De Ligorsche en Bordelonsche stonden daarentegen weinig bij de Patanische achter, wat wegens de nabijheid dezer beide plaatsen ook begrijpelijk is ${ }^{4}$ ) Ook als we een vergelijking maken met het oudste peperkantoor, dat reeds op den eersten tocht naar Indië als zoodanig de aandacht trok, Bantam, valt de superioriteit van het Patanische gewas op. Reeds Roelof Roelofsz, de beschrijver van den tocht van Van Neck, weet te vertellen, dat de peper ,in 't Coninghrijck van Patane ende sommighe andere landen daer omtrent seer goed ende schoon valt, doch wat dierder te staen komt als te Bantam" ${ }^{5}$ ). Het nadeel voor Patani was echter, dat in patria beide soorten meest over een kam werden geschoren, althans de Patanische peper lang niet in verhouding tot de betere kwaliteit duurder werd betaald. Peter Segers, in 't laatst van 1612 uit Bantam aan bewindhebbers schrijvende, vindt 't dan ook goed, dat er voorloopig geen peper meer in Patani gekocht wordt, „,vermits in onse landen neffens den Bantamschen wech gaet; is nochtans schoonder gemaeckt ende gewandt", en ook veel grover en zwaarder $\left.{ }^{6}\right)$. Coen huldigt in een schrijven van Januari 1614 een

1) Pag. 39.

2) Copie-betoog van Matelief de Jonge, dat het niet geraden is, Johor tot zetel van den G.-G. te kiezen, 31 Aug. 1610 (Kol. Aanw. No 53: Hugo Grotius; zie Rotterdamsche Historiebladen III, deel I, p. 328 v.).

3) Pag. 135 v.

4) Copiebrief van Victor Sprinckel aan Van den Broecke, Patani, 25 Sept. 1608 (Copieboek V. S.) ; Hendrik Janssen aan beww. te Amst., Patani, 25 Oct. 1616; Prijscourant van koopmanschappen, zooals die in Patani golden in Sept. 1617, Patani, Sept. 1617.

5) In Begin ende Voortgangh, d1. I, p. 17.

6) Peter Segers aan beww. kamer Amst., Bantam, 5 Dec. 1612. 
minder absoluut standpunt: de Patanische grove peper zal weliswaar moeten gekocht worden, maar niet al te duur in verhouding tot de kleine peper uit Bantam; de factorijhouders zullen verder rekening moeten houden met de vermoedelijke opbrengst in patria ${ }^{1}$ ).

Niet steeds was de pepermarkt in Patani even levendig: door allerlei omstandigheden konden quantum en prijsverloop van het artikel worden beïnvloed. De komst der Nederlanders, eerst in 1601 alleen met de Amsterdam en de Gouda, dan in 't volgende jaar nog met de Middelburg en de Zon, de Alkmaar en de Witte Leeuw ${ }^{2}$ ), bracht economisch een grooten schok in de bocht van Patani te weeg: we zagen, hoe de peperprijs, die volgens Van Neck vóór dien tijd op 15 realen per baar stond, tot het dubbele steeg, en dat nog wel eerst na een moeizaam en langdurig loven en bieden ${ }^{3}$ ). Natuurlijk is de toen nog bestaande concurrentie van verschillende Nederlandsche combinaties een verklaring voor het feit, dat men ondanks den sterk opgedreven prijs toch voor dien tijd groote quanta peper inkocht: Van Neck \pm 3000 baren, de Zeeuwen 1300, Heemskerck ruim 1000, zoodat dus in het eene jaar 1602 ongeveer 5300 baren door de Nederlanders werden afgescheept ${ }^{4}$ ).

Toen in November 1603 Cornelis Pietersz. met de Zierikzee en de Hollandsche Tuin Patani bezocht, werd een peperprijs van 35 realen geëischt ${ }^{5}$ ). De inlanders hadden blijkbaar de overtuiging, dat aan de Hollanders steeds meer te verdienen was, en de pepermarkt in Holland elke beschikbare hoeveelheid gretig zou blijven opnemen.

Maar dit was toch onjuist. In de bestuursperiode van Ferdinand Michiels toonden de Nederlanders een groote verslapping van energie; geruimen tijd werd onze vestiging door geen enkel schip meer bezocht ${ }^{6}$ ), en verder was ook de leider te aarzelend, te scrupuleus, om met goed succes den peperhandel te kunnen voortzetten ${ }^{7}$ ). De mindere gretigheid, van Hollandschen kant getoond, moest de peperprijzen we! doen dalen. In 1608, tijdens 't bestuur van Victor Sprinckel, is de prijs ongeveer 19 realen per baar ${ }^{8}$ ). Maar juist in dien tijd werd het product in patria bijna niet meer begeerd: een ware pepermalaise is

1) J. P. Coen aan beww. te Amst., Bantam, 1 Jan. 1614 (Col. Coen I, p. 1 v.).

2) Zie hoofdstuk I.

3) Zie p. $5 \mathrm{v}$.

4) Pag. 8 en p. 11 .

5) Zie p. 19

6) Zie p. 28 v.

7) Zie p. 29.

8) Copiebrief van Victor Sprinckel aan Abraham (van den Broecke?), Patani, 
op de Europeesche markt ingetreden. In April 1608 werd met het jacht de Goede Hoop een memorie naar Indië gezonden, bestemd voor admiraals, vice-admiraals, opper- en ondercommiezen, waarin tegen het onbeteugelde opkoopen van peper gewaarschuwd werd: ook al door de groote voorraden, welke door de Portugeezen werden aangebracht, zat men in Nederland met zoo groote hoeveelheden, die bijna onverkoopbaar waren, dat men in Indië liever veel geld aan zijde dan aan peper moest besteden ${ }^{1}$ ).

Omstreeks 1612 is de toestand in Europa blijkbaar weer veranderd. Bewindhebbers zijn dan niet meer van peperzendingen uit Patani afkeerig, mits men zich daar niet te eenzijdig op toelegt, en ook, tegen matigen prijs, den zijdeïnkoop behartigt ${ }^{2}$ ). Het was echter in de komende jaren voor Hendrik Janssen niet altijd gemakkelijk, de benoodigde hoeveelheden bij elkaar te krijgen: jaar op jaar werden de peperaanplantingen, zooals we reeds zagen, door overstroomingen geteisterd ${ }^{3}$ ). En een te hoogen prijs mocht men niet betalen, anders zou men te zeer in tegenstelling komen met de markt van Bantam ${ }^{4}$ ) : in een prijscourant van 1617 vinden we de Ligorsche en Bordelonsche peper genoteerd à 16 tot 18 realen per baar, al is het ook moeilijk, er dan een groote partij van te bekomen ${ }^{5}$ ).

Omstreeks dien tijd vangt echter een nieuwe hoogteperiode aan: Coen geeft, als de Galjas op 17 April 1617 naar de bocht van Patani gezonden wordt ${ }^{6}$ ), de opdracht mee, dat zoowel in Patani als Sangora alle peper moet worden opgekocht, die men bekomen kan : de bewindhebbers, zoo schrijft hij nader aan Hendrik Janssen, beschouwen dan de peper weer als een der meest begeerde artikelen.

En spoedig spelen ook de gebeurtenissen in Bantam een stimuleerende rol, waardoor Patani van nog grooter belang wordt. De

1 Mei 1608 (Copieb. V. S.); idem aan Van den Broecke, 25 Sept. 1608 (Copieb. V. S.); idem aan Jacques l'Hermite te Bantam, Patani, 25 Sept. 1608 (Copieb. V. S.).

1) Copie-memorie voor de admiralen, vice-admiralen, opper- en ondercommiezen in Indië, 12 April 1608; vgl. ook De Jonge III, p. 120.

2) Uit naam der beww. aan Peter Segers te Patani, of diens opvolger, Amsterdam, 28 April 1612.

3) $\mathrm{Zie}$ p. 92 .

4) Zie p. 153 v.

5) Prijscourant van koopmanschappen, zooals die in Patani golden in Sept. 1617, Patani, Sept. 1617.

6) Zie p. 83; verder: Copiebrief van J. P. Coen aan Hendrik Janssen te Patani, Jacatra, 17 April 1617 (Col. Coen II, p. 226 v.); idem aan C. van Nieuwenroode te Sangora, Jacatra, 17 April 1617 (Col. Coen II, p. 230); idem aan Hendrik Janssen te Patani, Jacatra, 23 April 1617 (Col. Coen II, p. 236 v.) 
peperinkoop werd namelijk in Bantam omstreeks het einde van 1617 zeer bezwaarlijk, en wel door een soort monopoliseering, waartoe zich de rijksbestierder Ranamanggala met een Chinees verbonden had: alleen bij deze combinatie kon de Compagnie nu koopen, en de prijzen rezen hierdoor al spoedig tot in het onredelijke ${ }^{1}$ ). Nog erger werden de omstandigheden, toen de gespannen commercieele verhoudingen met Bantam overgingen in openlijke vijandschap. Dit geschiedde in verband met het bekende beleg van Jacatra, waarbij Bantam deels uit de verte, deels door actief ingrijpen, den toestand trachtte te beheerschen. Nadat op den gedenkwaardigen $30^{\text {en }}$ Mei 1619 het benarde Jacatra door Coen was ontzet, kondigde deze dreigend zijn komst voor Bantam aan, waarop Ranamanggala deze stad in staat van tegenweer bracht. En al behaalde Coen hier ook het succes, dat de Nederlandsche gevangenen werden uitgeleverd, toch liet de rijksbestuurder den peperinkoop niet weder op den ouden voet toe. Coen, geen man van halve maatregelen, beantwoordde dit door de haven van Bantam te blokkeeren, een toestand, die bijna onafgebroken tot 1659 voortduurde ${ }^{2}$ ).

Deze gebeurtenissen nu doen, evenals ook in andere peperkwartieren, geducht hun weerslag gevoelen in Patani. Wij merken dit, als in 1618 de Zwarte Leeuw en het jacht Jacatra door Coen naar Patani worden gezonden ${ }^{3}$ ). Toegeven aan de boosheid van den pangoran van Bantam, door diens boozen wil te worden gedwongen, aldus Coen, is ontoelaatbaar: beter dan nog, desnoods op andere pepermarkten den hoogsten prijs te betalen ! Alle peper, schrijft hij aan Hendrik Janssen, die uit Siam, Cambodja, Patani, Sangora, Bordelon, Ligor en omliggende kwartieren te krijgen is, moet in de Zwarte Leeuw overgezonden worden ${ }^{4}$ ). Aan dezen last is inderdaad zoo goed mogelijk gevolg gegeven: aan peper uit Bordelon en Ligor werd ingeladen de belangrijke hoeveelheid van ruim 1334 baar, samen kostende $f$ 89229.10.-, dat is dus gemiddeld de nog al hooge prijs van bijna $f 67$ per baar ${ }^{5}$ ). Dat de $Z$ warte Leeuw tot onze groote

1) Colenbrander: Koloniale Geschiedenis II, p. 104.

2) Col.: Kol. Gesch. II, p. 105 v.

3) $\mathrm{Zie}$ p. 84 .

4) Copiebrief van J. P. Coen aan Hendrik Janssen te Patani, in 't schip Zierikzee, liggend aan de eilanden van Jacatra, 30 Mt. 1618 (Col. Coen II, p. 360 v.).

5) Factuur van 't cargasoen, geladen door Hendrik Janssen in de Zwarte Leeuw, Patani, 15 Oct. 1618; Copiebrief van Gerrit Frederiksz. Druyff aan beww., Patani, 1 Nov. 1618; J. P. Coen c.s. aan beww., in 't schip de Oude Zon, 
schade op den terugtocht aan de Engelschen verloren ging ${ }^{1}$ ), was dan ook uit een oogpunt van peperaanvoer zeer te betreuren.

Maar de pogingen, veel peper uit de Bocht te betrekken, hielden aan. Coen schrijft, als hij in Mei 1620 de Zeewolf naar Patani zendt ${ }^{2}$ ), aan Druyff, dat hij goede resultaten verwacht van den nieuwen peperhandel in die streken, waarvan hij vernomen heeft: 1500 a 2000 baren hoopt hij in 1621 daarvandaan te betrekken; nieuwe aanplant moet met kracht bevorderd worden, „opdat Bantam t' eenenmael moghen derven" ${ }^{3}$ ). En in October van 1620 meldt Van Hasel uit Sangora reeds, tot 35 realen per baar te hebben betaald ${ }^{4}$ ).

Een nieuwe pepermalaise in Europa trad omstreeks 1621 in. Hiertoe werkten in de eerste plaats mede de troebelen in Polen tijdens de woelige regeering van Sigismund III, en verder waarschijnlijk ook wel de economische ellende, die door den 30-jarigen oorlog in Duitschland werd veroorzaakt ${ }^{5}$ ). Eigenaardig is echter, dat de bewindhebbers eenerzijds, naar Indië schrijvende, klaagden over 't prijsverloop, dat hiervan 't gevolg was, maar anderzijds toch bevalen, tot nader order zooveel peper te zenden, als men zou kunnen bekomen ${ }^{6}$ ). Hierop nu kwam weliswaar een terugslag: in April 1622 wordt uit patria in een schrijven aan Coen geklaagd over het ,hert jagen om groote menichte van peper op te soecken" ${ }^{7}$ ), waarbij de plaatsen aan de bocht van Patani met name genoemd worden, maar veel invloed van dezen brief merken we niet: nog na het opheffen van 't kantoor in Patani wordt van den peperinkoop aldaar, al is 't tot hoogen prijs, veel werk gemaakt ${ }^{8}$ ).

In de tijden, dat men order had, zooveel mogelijk van de Patanische peper in handen te krijgen, werd natuurlijk fel gekeken op de concurrenten, die ons daar bij den inkoop konden benadeelen. Dat de

liggende voor Mandalique, omtrent 3 mijlen bij Oosten Japara, 14 Jan. 1619 (Col. Coen I, p. 416 v.); Beschrijving, hoe de Engelschen in Dec. 1618 tegen ons een generalen oorlog aangevangen hebben en hoe de oorlog te Jacatra begonnen is.

1) Zie hoofdstuk VII.

2) Zie p. 99.

3) Copiebrief van J. P. Coen aan G. F. Druyff te Patani, Jacatra, 15 Mei 1620 (Col. Coen II, p. 707 v.).

4) Jan van Hasel aan J. P. Coen te Jacatra, Sangora, 4 Oct. 1620.

5) Zie ook mijn artikel: Bezuinigingsmaatregelen van Jan Pietersz. Coen, Tijdschr. voor Gesch. 1934, p. 20.

6) Copiebrief naar Patani aan Gerrit Frederiksz. Druyff, Batavia, 2 Juni 1622.

7) Copiebrief van kamer Amsterdam aan J. P. Coen, Den Haag, 14 April 1622 (Col. Coen IV, p. 536 v.).

8) Zie de gegevens hierover in hoofdstuk VIII. 
Engelschen hierbij als geduchte mededingers werden beschouwd, is begrijpelijk; ik kom hierop trouwens nader terug. Ook de Chineezen bemoeilijkten, zooals we reeds zagen, de Patanische factorijhouders zeer bij hun taak, wat immers tot drastische maatregelen onzerzijds leidde ${ }^{1}$ ). Een derde „lek" werd gevormd door den peperafvoer naar Siam. Talrijk zijn de klachten hierover. In 1616 en 1617 was het pepervervoer uit de Bocht naar dit land b.v. groot, in 1617 wel over de 1000 baren $^{2}$ ). En zelfs in 1625 nog wordt er door Pieter de Carpentier c.s. in een generale missive ${ }^{3}$ ) over geklaagd, dat de oorzaak van de blijvende duurte in de Bocht gelegen is in den aftrek van Siam, vanwaar dan de peper verder vervoerd wordt naar Tenasserim en Pegu en voorts met 's konings jonk naar China. Waar de onzen niet bij machte waren, dit vervoer te voorkomen, was natuurlijk het eenige correctief, dat ze ook in Siam ter markt gingen om daar de peper op te koopen; de streek leverde trouwens ook zelf dit product op, zooals we lezen in het reisverhaal van Roelof Roelofsz over den tocht van Van $\mathrm{Neck}^{4}$ ).

$\mathrm{Na}$ aldus den peperhandel van Patani van verschillende kanten bekeken te hebben, kom ik nog eens terug op het oordeel van Cornelis Matelief de Jonge, die zoo breedvoerig zijn meening over deze factorij uiteengezet heeft ${ }^{5}$ ). Evenmin als voor den Chineeschen handel, we zagen het reeds, vindt hij voor den peperhandel het kantoor noodig, daar immers eigen productie gering is tegenover den export. En Coen, in lateren tijd, begeerig naar vereenvoudiging van den kostbaren „ommeslag" der Compagnie, uit zich op soortgelijke manier: noch zijde- en porselein, $\left.-^{6}\right)$, noch peperhandel rechtvaardigde de kantoren aan de Bocht. Maar er is groot verschil. Al zou Coen voor beiderlei handelsbelang graag zijn geliefd Jacatra-Batavia tot stapelplaats gemaakt zien, dit ideaal zou, hij ziet dat in, niet op korten termijn te verwezenlijken zijn. Daarom, wat zijde en porselein betreft, voorloopig een andere vestiging, dichter bij het land van oorsprong: de vestiging in Cochinchina! Wat echter de peper betreft, daarvoor was geen

1) Zie p. 135 v.

2) Prijscourant van koopmanschappen, zooals die in Patani golden in Sept. 1617, Patani, Sept. 1617; Copiebrief van Hendrik Janssen aan J. P. Coen te Bantam, Patani, 25 Oct. 1617.

3) Generale missive van Pieter de Carpentier c.s. aan beww., Batavia, 27 Jan. 1625.

4) (In Begin ende Voortg. I), p. 21.

5) Vgl. p. 39 en 152 v.

6) Pag. 141 . 
nieuw kantoor noodig als tusschenstadium: men ging, zooals we zagen, ook na opheffing van het kantoor er mee voort, de Bocht met schepen te bevaren, en zelfs, waar de peper zeer begeerd was, op intensieve manier. Maar men zou den Pataniërs van ' $t$ begin af den weg moeten wijzen naar Batavia. De peper, zoo lezen we in een brief van $1622^{1}$ ), uit Batavia aan Druyff in Patani geschreven, zal jaarlijks met schepen en jachten heel goed verkregen kunnen worden, ,terwyle ende tyde ${ }^{2}$ ) d' inwoonders oft andere gebuerighe natien soo verre gebracht sullen wesen door 't verleyden ${ }^{3}$ ) van de negotie, dat om haer eygen proffyt ende gerieff ons selver den peper toe brenghen". Liever duur in Batavia inkoopen dan de peper zelf in vreemde landen te gaan zoeken, zoo lezen we in een anderen brief van 't zelfde jaar ${ }^{4}$ ). Maar het doel, dat Coen zich had gesteld, zou nog in geen jaren worden bereikt ${ }^{5}$ ).

1) Copiebrief naar Patani aan Gerrit Frederiksz. Druyff, Batavia, 15 Juni 1622.

2) = totdat.

3) $=$ verleggen.

4) Copie-brief naar Jambi aan Adriaen van der Dusse, Batavia, 6 Juli 1622. Vgl. ook: Copiebrief van J. P. Coen aan Carpentier, in 't schip Mauritius tusschen Craketouw en Dwars in de Wech, 9 Febr. 1623 (Col. Coen III, p. 308 v.).

5) In een generale missive van 3 Nov. 1628 uit Batavia wordt meegedeeld, dat in dat jaar geen schepen naar de bocht van Patani zijn gezonden, omdat de peper in 1627 duur was, en men voorts moeilijk een schip ervoor beschikbaar kon stellen. Hieruit blijkt dus, dat deze vaart nog niet voorgoed geëindigd was. 


\section{VIJFDE HOOFDSTUK.}

\section{Verder nut van Patani.}

Had men met het stichten van de factorij van Patani zich veel voorgesteld van den handel in Chineesche waren en peper, de mogelijkheden waren daarmede geenszins uitgeput. In den loop der jaren heeft men ook overwogen, deze plaats tot een station voor voedselvoorziening te maken voor Oostelijker gelegen streken. Reeds voor Van Neck gold het gebied rondom Patani als een land, overvloeiende van melk en honig ${ }^{1}$ ). Ook de ziekentrooster Roelof Roelofsz, die Van Neck's tocht beschreven heeft, is zeer enthousiast: rijst, groene erwten, cocosolie, vruchten, runderen, wild, dat alles is in Patani te krijgen, ook varkens, maar alleen wilde; de teelt ervan zou voor de Mohammedaansche bevolking natuurlijk een reden tot groote ergernis geweest zijn; ja, de Hollanders konden er zelfs alleen in 't geheim varkens slachten ${ }^{2}$ ).

Het is dan ook te begrijpen, dat in 't algemeen de schepen, die Patani aandeden, hier gemakkelijk ,verversching” konden opdoen en ook levensmiddelen als handelswaar inladen. We zagen bijvoorbeeld reeds, hoe Heemskerck in 1602 een lading rijst an boord kreeg ${ }^{3}$ ), terwijl in 't volgende jaar de Erasmus en de Nassau voor Patani lagen om verversching en rijst in te laden $\left.{ }^{4}\right)$. Bijzonder belang kreeg de plaats plotseling voor de levensmiddelenvoorziening, toen in 1609 admiraal Verhoeff op de Banda-eilanden vermoord was en daarna zijn vice-admiraal Wittert in de Philippijnen was gesneuveld ${ }^{5}$ ). We hebben reeds besproken, hoe toen Victor Sprinckel zijn maatregelen nam om eventueel de opvarenden van de schepen der ongelukkige vloot, zoo ze de haven van Patani opzochten, van vleesch te voorzien $^{6}$ ), tevens, hoe inderdaad in 1610 eerst de sloep van de Delft, en

1) Vgl. p. 3 v.

2) Roelof Roelofsz (in Begin ende Voortgangh I), p. 17 v.

3) Zie p. 11 .

4) Zie p. 14 .

5) Zie p. 52 v.

6) $\mathrm{Zie}$ p. 53. 
vervolgens het jacht de Pauw waren verschenen, tenslotte ook nog het schip Delft zelf, dat door Van Caerden naar Patani was gezonden met order, dat de Pauw met provisie naar de berooide Molukken moest worden gezonden, wat dan ook op 10 October gebeurde ${ }^{1}$ ).

Sprinckel opende ten opzichte van de levensmiddelenvoorziening ruimere perspectieven dan het ververschen van komende schepen en het zoo nu en dan verschepen van eenige levensmiddelen als handelswaar: in een breed vertoog aan bewindhebbers ${ }^{2}$ ) zette hij als zijn meening uiteen, dat geregelde belangrijke zendingen van levensmiddelen en andere behoeften naar de Molukken zouden kunnen plaats hebben. Het spreekt vanzelf, dat dit niet voor doovemansooren gezegd werd: het medegeven van provisie met de Compagniesschepen voor de lange reizen naar Indië was reeds bezwaarlijk genoeg; dat men bovendien nog voor de factorijen en forten in 't Oosten van den Archipel te zorgen had, ondervond men in patria als een grooten extra-last. En nu had Sprinckel in dit opzicht het verlossende woord gesproken! Geen wonder, dat door Heeren XVII in Maart 1614 een resolutie getrokken werd, dat men den Gouverneur-Generaal, de Raden en de commiezen in Indië zou waarschuwen, dat ze voortaan niet meer zooveel provisie uit 't vaderland zouden te verwachten hebben, maar dat ze zich daar te lande uit Siam, Patani, Amboina e.a. kwartieren moesten provideeren, alles volgens de inlichtingen, die Sprinckel omtrent dit vraagstuk had verstrekt ${ }^{3}$ ). Op 4 April werd een desbetreffend schrijven naar Indië gezonden ${ }^{4}$ ).

Dit besluit van Heeren XVII verwekte in Indië groote ontsteltenis, en het regende beschuldigingen aan 't adres van Victor Sprinckel, die door zijn misplaatst optimisme de voedselvoorziening in 't verre Oosten in gevaar gebracht had! We wezen hier vroeger, bij de beoordeeling van Sprinckel's karakter, reeds in 't voorbijgaan op ${ }^{5}$ ), maar willen nu nog even meer uitdrukkelijk bij deze kwestie stilstaan. Men zou namelijk de vraag kunnen opwerpen, of niet de belanghebbenden in een onberedeneerde angst, dat in de Molukken hongersnood zou ontstaan, al te spoedig tot onbekookte kritiek tegen Sprinckel bereid waren. Maar hiervoor zijn de autoriteiten, die Sprinckel be-

1) Zie p. 51 v.

2) Copiebrief van J. P. Coen aan Hendrik Janssen, Bantam, 10 Juni 1615 (Col. Coen II, p. 10 v.); het vertoog zelf heb ik niet aangetroffen.

3) Resolutie der XVII in hun vergadering van Maart 1614.

4) J. P. Coen aan beww. kamer Amst., Bantam, 22 Oct. 1615 (Col. Coen I, p. 114 v.).

5) Zie p. 57.

Verh. dl. I. 
strijden, toch te talrijk en te hoog in aanzien, en hun argumenten in 't algemeen te zeer voor de hand liggend. Hooren we ten eerste Coen's oordeel $\left.^{1}\right)$. Het is waar, zoo schrijft hij aan bewindhebbers van Amsterdam, dat sommige kantoren in Indië tot de proviandeering der andere wel iets kunnen bijdragen - hij noemt hierbij Japan als loffelijk voorbeeld -, maar dit is slechts een druppel in den emmer; bovendien: zou de Compagnie haar levensmiddelenzendingen naar Indië verminderen, dan zou men de weinige gezonden contanten, die men maar al te zeer voor de begeerde handelsartikelen noodig heeft, aan opkoop van proviand moeten besteden, proviand, die in Nederland goedkooper dan hier te verkrijgen is. Reynst wijst er op ${ }^{2}$ ), dat, waar bij de komst van een schip in Patani de opvarenden "tot hare ververschinge" wel tusschen 10 en 20 ossen kunnen bekomen voor 4 à 6 realen per stuk, het heel iets anders zou worden, als men jaarlijks voor de proviandeering van 't Oosten er 100 tot 130 wilde inslaan: zooveel zouden nauwelijks te krijgen zijn, en de prijs zou tot 15 à 16 realen per stuk oploopen. Reael noemt, zooals we zagen, Victor Sprinckel eenvoudig een grootspreker: al slachtte men van 't geen in Patani te krijgen was een half jaar achter elkander, dan zou dit nog niet voldoende zijn om de Molukken voor twee jaren te voorzien, schrijft hij in $1616^{3}$ ), terwijl 't vleesch van Patani bovendien voor dit doel slecht te gebruiken was. Dit laatste punt nu wordt uitvoerig uitgewerkt door Hendrik Janssen, dien we in deze kwestie wel als de meest betrouwbare autoriteit mogen beschouwen. In twee brieven, een naar Bantam ${ }^{4}$ ) en een aan bewindhebbers te Amsterdam ${ }^{5}$ ), zet hij zijn meening uiteen. Het betoog, door Sprinckel aan heeren Meesters overgegeven, zoo zegt hij, ,is in veele synder discours geabuseert". Ossen, koeien en bokken zouden wel te verkrijgen zijn, ook wel het daarvoor benoodigde zout, ja, bij het zenden van gezouten vleesch naar de Molukken zou op zich zelf $50 \%$ of weinig minder winst te behalen zijn. Maar het bedenkelijke punt is, dat dit vleesch het zout niet lang verdraagt: het wordt „,seer sponsachtich, ende onbequaem voor spijse te gebruijcken", en blijft ten hoogste veertig dagen eetbaar, wat te kort is, als men bedenkt, dat het vervoer naar

1) J. P. Coen aan beww. kamer Amst., Bantam, 22 Oct. 1615 (Col. Coen I, p. 114 v.).

2) Gerard Reynst aan beww., Bantam, 26 Oct. 1615.

3) Copiebrief van Laurens Reael aan beww. te Amst., Ternate, 11 Juli 1616.

4) Copiebrief van Hendrik Janssen aan 't kantoor Bantam, Patani, 15 Nov. 1615.

5) Hendrik Janssen aan beww. te Amst., Patani, 25 Oct. 1616. 
de Molukken op zich zelf wel op 4 à 5 weken te stellen is. Cocosolie en spek zijn alleen bij tijden te verkrijgen, en dan geldt voor het spek hetzelfde bezwaar van bederf : het Siamsche spek, dat door Sprinckel met het jacht de Pauw naar de Molukken gezonden was, „,wert verclaert wel halff bedorven ende qualyck etelyck is geweest". Wat verder boonen en erwten betreft, is er ,somtijts een schoetel voor de taffel te becommen", niet voor export dus. Alleen was cocosnoten en arak betreft, staat het gunstiger : beide artikelen zijn voldoende te verkrijgen om er de Nederlanders in de Molukken mee te voorzien, echter alleen met voordeel, als daar toch schepen heen bestemd zijn; met expresse jonken deze waren erheen te zenden, zou geen zin hebben, daar ze dan de vracht niet half waard zouden zijn.

Aan bovenstaande pessimistische beoordeelingen valt nog het volgende ten nadeele van Patani toe te voegen: het ging er met de levensmiddelen als met de peper: lang niet alles, wat er door de Nederlanders ingekocht werd, kwam er vandaan. Ook hier weer zien we, dat Patani als handelscentrum belangrijker is dan als productieplaats. Zoo wist Sprinckel, toen hij, gelijk vermeld, schepen van de ongelukkige vloot van Verhoeff verwachtte, niet beter te doen dan een grooten voorraad varkensvleesch aan Lambert Jacobsz. Heyn in Siam te bestellen ${ }^{1}$ ). Ook alle arak, die uit Patani kwam, zal daar niet gebrand zijn : in 1613 schrijft Marten Houtman uit Siam over Chineesche arak, hem door Hendrik Janssen uit Patani gezonden ${ }^{2}$ ). En Victor Sprinckel geeft in een schrijven van 1608 te kennen, dat de boter, die hij in Patani meest koopt, van Queda afkomstig is ${ }^{3}$ ). Maar het belangrijkste voedingsartikel, waarvoor de gemaakte opmerking geldt, is de rijst. De inwoners van Patani, zoo schrijft Hendrik Janssen in $1616^{4}$ ), moeten jaarlijks het grootste deel van de rijst, die ze noodig hebben, uit Ligor en de streek van Sangora halen: van het eigen gewas kan de bevolking niet half gespijzigd worden. Hiermee klopt een mededeeling uit $1620^{5}$ ), dat uit Sangora jaarlijks van 500 tot 600 lasten rijst naar Patani en andere plaatsen plegen uitgevoerd te worden. Druyff schrijft in 1619 uit Patani over een

1) Zie p. 53.

2) Copiebrief van Marten Houtman aan Hendrik Janssen te Patani, Ajudhja, 18 Mt. 1613. Zie ook p. 132.

3) Copiebrief van Victor Sprinckel aan Van den Broecke, Patani, 25 Sept. 1608 (Copieb. V. S.).

4) Hendrik Janssen aan keww. te Amst., Patani, 25 Oct. 1616.

5) Jan van Hasel aan J. P. Coen te Jacatra, Sangora, 4 Oct. 1620. 
partij rijst, die in Sangora is ingekocht ${ }^{1}$ ); volgens een brief uit het volgende jaar heeft hij 60 lasten gekocht uit een jonk, die uit Siam was gekomen ${ }^{2}$ ).

Weinig zullen de autoriteiten, die in 1615 en 1616 zoo unaniem waren in hun veroordeeling van Sprinckel's optimisme, gedacht hebben, dat een paar jaren later de meest dringende smeekbeden van ' $t$ hoofdkantoor naar Patani gericht zouden worden juist terwille van de voedselvoorziening van het Oosten. In Augustus 1618 werd de Nederlandsche factorij te Japara op de meest onverwachte wijze overvallen en geplunderd door de onderdanen van Agoeng, den vorst van 't Javaansche rijk Mataram. Drie Nederlanders lieten hierbij het leven; anderen werden gekwetst, de rest naar 't hof van genoemden vorst gevoerd. Een jarenlange oorlogstoestand volgde hierop. Het kan niet onze bedoeling zijn, de bijzonderheden hiervan na te gaan; voor ons is alleen de terugslag op Patani van belang. De Mataram, zooals ook wel de vorst van dit rijk werd genoemd, beschikte over de groote rijsthavens van Java, en de onzen hadden zich, om dit product in handen te krijgen, eerst bediend van Grissee, gelegen bij Soerabaja, later van Japara, midden aan de Noordkust van Java ${ }^{3}$ ). $\mathrm{Nu}$ kwam hier nog iets bij : in dezen tijd stonden de onzen eveneens op slechten voet met Makassar, een andere uitvoerplaats van rijst. Houdt men nu rekening met den kritieken strijd om Jacatra, dat hoofdfeit in onze koloniale groeiperiode, een strijd, die spoedig volgde op het verlies van Japara, dan wordt het duidelijk, van hoeveel belang de proviandeeringsstations werden, waarover de Compagnie nog beschikte.

Op 29 Augustus, reeds drie weken nadat de noodlottige gebeurtenis te Japara had plaats gevonden, richt Coen zich door middel van een smak via Jambi tot Hendrik Janssen en Druyff in Patani $\left.{ }^{4}\right)$ : dezen moeten in Cambodja, Patani en alle omliggende kwartieren zooveel rijst doen opkoopen, als ze kunnen krijgen en verschepen. En reeds eenige dagen later wordt het jacht Hollandia terwille van het slagen der approviandeering naar Patani gezon$\left.\operatorname{den}^{5}\right): 8000$ realen krijgt het voor den rijstinkoop mee ${ }^{6}$ )! Ook naar

1) Gerrit Frederiksz. Druyff aan beww. kamer Amst., Patani, 26 Mt. 1619.

2) Gerrit Frederiksz. Druyff aan J. P. Coen te Jacatra, Patani, 8 Mt. 1620.

3) Zie over 't bovenstaande: Colenbr.: Kol. Gesch. II, p. 130 v.

4) Copiebrief van J. P. Coen aan Hendrik Janssen en Druyff, Jacatra, 29 Aug. 1618 (Col. Coen II, p. 418 v.).

5) Zie p. 84.

6) Copie-res. van pres. en raden, Jacatra, 3 Sept. 1618 (Col. Coen III, p. 
Bima $^{1}$ ) en de kust van Koromandel werd door Coen met het zelfde doel geschreven ${ }^{2}$ ).

Janssen en Druyff beijverden zich, zooveel ze konden : in de Zwarte Leeuw werden ruim 100 lasten rijst ingeladen, zoodanig, dat het schip daardoor zijn volle lading bekomen had ${ }^{3}$ ). Vergeefsche moeite! Met haar geheele kostbare lading viel de Zwarte Leeuw in handen der Engelschen ${ }^{4}$ )! In Maart 1619 heeft Druyff reeds weer 117 cojang $^{5}$ ) rijst gereed, in Sangora gekocht, welke hij van plan is, den $27^{\text {en }}$ van die maand naar Jacatra te zenden ${ }^{6}$ ), en wel met een jonk van nachoda ${ }^{\text {) }}$ Tinhongh. Deze jonk is inderdaad vertrokken, maar helaas ook al weer, zooals latere berichten ons leeren, genomen bij Bantam door de Engelschen ${ }^{8}$ ). Er scheen wel een noodlot te rusten op de rijstzendingen uit de Bocht! En zelfs als noch de Zwarte Leeuw, noch de jonk was prijs gemaakt, zou Coen nog bij lange na niet voldaan zijn: in denzelfden brief, met 't jacht Hollandia verzonden, wał̆rin hij Druyff het verloren gaan van de jonk bericht, verzoekt hij hem om een nieuwen voorraad van tenminste 500 last $^{9}$ ). En ook aan Jacques Specx in Japan heeft hij dan reeds om rijst geschreven ${ }^{10}$ ).

Maar het jaar 1619 brengt een wending ten goede. We zagen, dat toen Hendrik Janssen het belangrijke commando kreeg over de schepen de Bergerboot en de Engel, alsmede de jachten de Morgenster

453 v.); Copiebrief van J. P. Coen aan Hendrik Janssen en Druyff te Patani, Jacatra, 4 Sept. 1618 (Col. Coen II, p. 423 v.).

1) Op 't eiland Soembawa.

2) J .P. Coen c.s. aan beww., in 't Wapen van Amsterdam omtrent Jacatra, 29 Sept. 1618 (Col. Coen I, p. 381 v.).

3) Copiebrief van Gerrit Frederiksz. Druyff aan beww., Patani, 4 Oct. 1618.

4) Vgl. hoofdstuk VII.

5) Zie, evenals over last, p. 11 noot 1 .

6) Gerrit Frederiksz. Druyff aan beww. kamer Amst., Patani, 26 Mt. 1619. De prijs zou 3 gulden 4 stuivers de cojang hebben bedragen, behalve de onkosten. Dit is onzinnig laag. We moeten dan ook een vergissing in dit stuk aannemen, daar later, als de schade met de Engelschen verrekend wordt, de geheele rijstlading met inbegrip van onkosten wordt gesteld op $f$ 6718.12.(Notitie van de schaden en intresten, die de O.I.C. door de Engelschen en door hun toedoen geleden heeft, onderteekend door Pieter de Carpentier en Dedel).

7) Perz. nã-khudā: schipper (zie Hobson-Jobson s.v. Nacoda).

8) Copiebrief van J. P. Coen aan Gerrit Frederiksz. Druyff, Jacatra, 2 Juni 1619 (Col. Coen II, p. 555 v.); de notitie van de schaden etc., genoemd in noot 6.

9) De copiebrief, genoemd in noot 8 .

10) Copiebrief van J. P. Coen aan Jacques Specx in Japan, Amboina, 4 April 1619 (Col. Coen II, p. 534 v.). 
en de Jager, waarvan het laatste bestemming had naar Jambi, de eerste drie Patani ${ }^{1}$ ). Behalve offensieve bedoelingen tegen de Engelschen waren er ook nu, zooals begrijpelijk is, weer handelsbelangen te behartigen, en weer speelde de rijstbehoefte voor de forten en schepen een groote rol. Daar alle rijst, door Druyff gezonden, zoo schreef Coen aan dezen, in handen van de Engelschen gevallen was, moest hij een goede partij zien te verkrijgen en die dan met de best mogelijke scheepsgelegenheid verzenden. Ook olie, gedroogde visch en allerlei andere provisie zou welkom zijn ${ }^{2}$ ). In totaal was voor Patani een kapitaal van 120000 realen bestemd $\left.{ }^{3}\right)$. Maar ook Cornelis van Nieuwenroode in zijn factorij van Ajudhja werd aangeschreven om zooveel mogelijk rijst te zenden ${ }^{4}$ ). En daarbij bleef het niet: de commandeur van de vloot moest, zoo luidde zijn opdracht, bovendien nog trachten te bewerken, dat van Cambodja, Tsi-ampa, Japan en andere kwartieren groote hoeveelheden werden gezonden, alles schoone, witte rijst, al was het tot 1000 lasten $^{5}$ ).

En deze poging van Coen was niet vergeefsch. Toen Hendrik Janssen den $10^{\text {en }}$ November na zijn roemrijke expeditie met de Bergerboot, de Morgenster en de twee Engelsche prijzen Sampson en Hound weer het anker voor Jacatra liet vallen, waren alle vier schepen volgeladen, wel niet uitsluitend met levensmiddelen, maar rijst en andere proviandeering maakten toch deel uit van de lading ${ }^{6}$ ).

Eenige dagen na Hendrik Janssen gingen uit Patani twee jonken zeil, die eveneens een lading rijst bevatten. In de eene, toebehoorende aan Radgia Indra, had Janssen 20 cojang gescheept, in de andere,

1) Vg1. over dezen tocht p. 96.

2) Copiebrief van J. P. Coen aan G. F. Druyff te Patani, Jacatra, 2 Juli 1619 (Col. Coen II, p. 571 v.).

3) Copie-res. van G.-G. en Raden, in 't schip de Trouw voor Bantam, 10 Juni 1619 (Col. Coen III, p. 514 v.).

4) Copiebrief van J. P. Coen aan C. van Nieuwenroode te Ajudhja, Jacatra, 2 Juli 1619 (Col. Coen II, p. 573).

5) Copie-instructie van J. P. Coen voor Hendrik Janssen en raad der schepen Engel, Bergerboot, Morgenster en Jager, Jacatra, 2 Juli 1619 (Col. Coen II, j. 575 v.).

6) Copiebrief van J. P. Coen aan gouverneur Speult op Amboina, Jacatra, 13 Dec. 1619 (Col. Coen II, p. 618 v.); J. P. Coen c.s. aan beww., Jacatra, 22 Jan. 1620 (Col. Coen I, p. 508 v.). Een aardig gegeven is nog, dat later, als de twisten tusschen de beide Compagnieën bijgelegd zijn, heeren Meesters zich verplichten, te Londen 1386 realen te betalen voor arak en rijst, met de Sampson en de Hound prijsgemaakt (Specificatie van alle veroverde Engelsche goederen, zoo die hier in Indië getaxeerd en gebeneficeerd zijn, onderteekend door Jacques Specx en Antonio van Diemen). 
wederom van Tinhongh, 60. Door tegenwind kwamen ze echter niet verder dan Redang ${ }^{1}$ ); ze keerden terug en arriveerden omstreeks 30 November weer voor Patani. In het allerlaatst van 1619 waagden ze nog een nieuwe poging, maar nadat ze door de koningin te lang waren opgehouden, ontmoetten ze onderweg veel storm en onweer en kwamen 12 Januari 1620 weer terug. Druyff liet zich echter niet ontmoedigen : toen voor Patani een jonk uit Siam verscheen met rijst aan boord, die bestemming had naar Malakka, wist hij de opvarenden te bewegen, hem 60 lasten rijst te verkoopen en daarmee, evenals met de rest van de lading, naar Jacatra te varen. Hierna verscheen plotseling \pm 16 Februari het jacht de $\operatorname{Vos}^{2}$ ), dat van Siam kwam, en eveneens rijst, alsmede ongeveer 230 potten cocosolie bracht. Deze laatste werd nu overgescheept in de jonk van Tinhongh, met 211/2 last rijst; 14 cojang werd aan boord van de jonk uit Siam gebracht ${ }^{3}$ ). Toen nu de drie jonken definitief uit Patani vertrokken, een ambassadeur van de koningin van Patani meevoerende, kregen ze het al weer met tegenwind te kwaad. Ze raakten van elkaar gescheiden: de twee Patanische jonken kwamen voor Palembang voor anker, de Siameesche was achtergebleven, en zocht Jambi op. Op 4 Juni 1620 zond Coen den opperkoopman Cornelis Comans met het Engelsche schip de Beer uit om de drie jonken te zoeken en er zoo noodig de rijst en de cocosolie uit over te nemen. Dit laatste is evenwel niet geschied: de drie vaartuigen, na beteren wind te hebben afgewacht, bereikten na hun ongelukkige Odyssee eindelijk Jacatra, waar ze uiterlijk 8 Januari 1621 aangekomen zijn ${ }^{4}$ ).

1) Eigenlijk 2 eilandjes: Groot- en Klein-Redang, liggende bij de Oostkust van het schiereiland van Malakka, het Zuidelijkste op $\pm 512^{\circ}$ N.B.

2) Zie p. 99.

3) In een brief van Gerrit Frederiksz. Druyff aan J. P. Coen te Jacatra, Patani, 8 Mt. 1620, staat een gegeven omtrent het overwegen van de rijst, volgens hetwelk de door de Vos aangebrachte hoeveelheid rijst iets kleiner zou moeten zijn geweest, maar hier zal wel een vergissing in 't spel zijn: het overige deel van dezen brief, waarop ik afgegaan ben, klopt heel aardig met een copiebrief van J. P. Coen aan A. J. van der Dussen te Jambi, Jacatra, 4 Juni 1620 (Col. Coen II, p. 720 v.), waarin de gezamenlijke rijstmassa van de drie jonken als 175 lasten wordt aangegeven.

4) Vgl. over de drie jonken, behalve de twee in noot 3 genoemde brieven ook nog: Copiebrief van Pieter de Carpentier ,ter ordonnantie van d' heer generael" aan Gerrit Frederiksz. Druyff te Patani, Jacatra, 21 April 1620 (Col. Coen II, p. 688 v.); Copiebrief van J. P. Coen aan G. F. Druyff te Patani, Jacatra, 30 Mei 1620 (Col. Coen II, p. 716 v.) ; Copie-instructie van J. P. Coen voor Cornelis Comans en raad van 't schip de Engelsche Beer, Jacatra, 4 Juni 1620 (Col. Coen II, p. 722 v.); Copiebrief van J. P. Coen aan Van der Dussen te Jambi, Jacatra, 23 Juni 1620 (Col. Coen II, p. 743 v.); J. P. Coen c.s. aan 
Inmiddels waren ook in het jaar 1620 weer herhaaldelijk nieuwe aanvragen om provisie uit het hoofdkwartier naar Patani gegaan. Reeds met de Sampson, die in Mei aan Druyff het bericht bracht van de overeenkomst, tusschen de Nederlandsche en de Engelsche Compagnie gesloten ${ }^{1}$ ), zal dit het geval geweest zijn. Immers als Druyff dit schip doorzendt naar Siam, is dit wel degelijk om daar levensmiddelen op te doen ${ }^{2}$ ). De Zeewolf vertrekt 15 Mei uit Jacatra $^{3}$ ) naar Patani, o.a. om ,verscheyde provisie” ${ }^{4}$ ). De Galjas, op 3 Juli uit Jacatra gezonden ${ }^{5}$ ), moet zooveel mogelijk schoone, witte rijst halen, verder olie en een groote partij $\left.\operatorname{arak}^{6}\right)$. Het jacht de Morgenster moet (evenals 't jacht Nassau, dat Patani niet bereikt heeft ${ }^{7}$ ), eveneens rijst, arak en andere provisie zien in te slaan ${ }^{8}$ ).

Het was evenwel niet te verwachten, dat in 1620 in Patani op ruime wijze aan deze opdrachten zou kunnen worden voldaan: door droogte was de rijstoogst vrijwel mislukt, waardoor groote duurte ontstond $^{9}$ ). In Sangora en in Ligor was het al even slecht gesteld, zoodat in de Bocht zelfs voor de inwoners de rijst van elders moest worden aangvoerd ${ }^{10}$ ). Van het schip de Zeewolf is me niet bekend, dat het in zijn taak is geslaagd; de Sampson bracht in December 1620 te Jacatra weliswaar rijst aan, maar uit Siam ${ }^{11}$ ); de Galjas kwam 7 Mei 1621 met 90 lasten rijst uit Cambodja ${ }^{12}$ ); nog later kwam de

beww., Jacatra, 31 Juli 1620 (Col. Coen I, p. 560 v.); Gerrit Frederiksz. Druyff aan J. P. Coen, Patani, 4 Nov. 1620; J. P. Coen c.s. aan beww., Jacatra, 8 Jan. 1621 (Col. Coen I, p. 606 v.); J. P. Coen c.s. aan beww., Batavia, 16 Nov. 1621 (Col. Coen I, p. 641 v.).

1) Zie p. 99.

2) Jan van Hasel aan J. P. Coen te Jacatra, Sangora, 4 Oct. 1620.

3) Zie p. 99.

4) Copiebrief van J. P. Coen aan G. F. Druyff te Patani, Jacatra, $15 \mathrm{Mei}$ 1620 (Col. Coen II, p. 707 v.).

5) Zie p. 100.

6) Copiebrief van J. P. Coen aan G. F. Druyff te Patani, Jacatra, 3 Juli 1620.

7) Zie p. 100.

8) Copie-res. van G.-G. en Raden, fort Jacatra, 27 Juli 1620 (Col. Coen III, p. 625).

9) Gerrit Frederiksz. Druyff meldt in zijn brief aan J. P. Coen te Jacatra, Patani, $8 \mathrm{Mt}$. 1620 (dít gedeelte er uit is reeds vroeger geschreven) als prijs voor roode rijst 20 tot 30 realen per cojang, de witte 33 à 34 , en hij vreest, dat deze spoedig tot 40 zal oploopen.

10) Vgl. behalve 't in noot 9 genoemde stuk: Copiebrief van J. P. Coen naar Firando aan Willem Jansz., commandeur over 5 schepen, Jacatra, 26 Juni 1620 (Col. Coen II, p. 749 v.); Jan van Hasel aan J. P. Coen te Jacatra, Sangora, 4 Oct. 1620; Gerrit Frederiksz. Druyff aan J. P. Coen, Patani, 4 Nov. 1620.

11) J. P. Coen c.s. aan beww., Jacatra 8 Jan. 1621 (Col. Coen I, p. 606 v.).

12) Pieter de Carpentier c.s. aan beww. kamer Amst., Jacatra, 9 Juli 1621. 
Morgenster uit Patani voor Jacatra, en wel in gezelschap van het jacht de Dolphijn uit Jambi, op 8 Juli 1621; van de beide jachten samen wordt gezegd, dat ze o.a. een partij rijst, arak en cocosolie in hadden ${ }^{1}$ ). We zien dus, hoe gering de rol was, die Patani voor de proviandeering gespeeld had.

Ook van de schepen, in 1621 naar Patani gezonden, is mij niet bekend, dat ze provisie mee terugbrachten. De Tholen en de Eenhoorn, die, zooals we reeds zagen ${ }^{2}$ ), in 't begin van 1622 te Batavia terugkwamen, brachten onder andere rijst uit Siam mee ${ }^{3}$ ). Het spreekt vanzelf, dat de schaarschte van 1620 in Patani ook meer de aandacht had gevestigd op het overvloed leverende rijstgebied Cambodja; we weten, hoe dit zelfs een van de redenen is geweest, dat onze landgenooten zich daar gingen vestigen ${ }^{4}$ ).

Plotseling schijnt de behoefte aan rijst uit die streken echter geluwd te zijn: in Mei 1621 schrijft Coen uit Amboina aan de raden van Indië, dat de Molukken en Banda dantertijd zeer wel voorzien zijn van rijst: men zal nu daarvoor Soekadana, Patani, Siam en Cambodja voorloopig wel kunnen missen en in de rijstbehoeften voorzien door middel van Jacatra, Koromandel en Japan ${ }^{5}$ ).

In 1622 herleefde echter de belangstelling voor Patani als voedselstation: Cornelis Reyersz. ondernam toen namelijk zijn tocht naar de Chineesche kust om met behulp van zijn scheepsmacht den handel aldaar definitief in handen te krijgen $\left.{ }^{6}\right)$. Het spreekt vanzelf, dat voor hem de plaatsen aan de Bocht, evenals trouwens ook Siam en Cambodja, zeer voordeelig lagen voor de voedselvoorziening. Op 20 November 1622 schrijft hij hierover naar Batavia. ,Was wel van noode, als UEd. hier schepen ofte jachten zijt sendende, dat eenige van deselvige Petania aendede om een partij appelen, lamoenen, beestiael als andere verversingen hier te brengen" ${ }^{7}$ ). Reeds was men te Batavia op dit punt diligent: een instructie van 2 Juni voor de opperhoofden der jachten Sincapura en Klein Tholen spreekt de wenschelijkheid uit, voor de vloot op de kust van China in Patani zoo veel „appelen, lamoenen ende andere ververschinge” te laden,

1) De op p. 168 noot 12 genoemde brief.

2) Zie p. 101.

3) J. P. Coen c.s. aan beww., Batavia, 26 Mt. 1622 (Col. Coen I, p. 703 v.).

4) Zie p. 108 v.

5) Copiebrief van J. P. Coen aan de Raden van Indië te Jacatra, Amboina, 29 Mei 1621 (Col. Coen III, p. 40 v.).

6) Vgl. Groeneveldt, p. 72 v.

7) Op. cit. p. 123. 
als men bergen $\mathrm{kan}^{1}$ ). En in 1624 treffen we wederom Patani in dezelfde rol: in Maart van dit jaar wordt in Batavia besloten, dat men tegelijkertijd zal uitzenden 't schip Noord-Holland, met bestemming naar Siam, en de jachten Witte Beer, West-Cappel en Purmerend naar Patani. Het schip heeft o.a. tot taak, in Siam rijst en andere provisie ${ }^{2}$ ) te laden, om daarmee naar de Pescadores $^{3}$ ) te zeilen. Van de drie jachten is de Purmerend bestemd, uit Patani eveneens levensmiddelen naar deze eilanden te vervoeren : vee, appels en andere verversching, zooveel als 't kan krijgen en laden. Van de jachten Witte Beer en West-Cappel heeft alleen het laatste een dergelijke opdracht, maar voorwaardelijk, namelijk als 't voor den handel in Patani gemist kan worden $\left.{ }^{4}\right)^{5}$ ).

We hebben echter de tijdruimte van het bestaan onzer factorij te Patani hiermee reeds overschreden. Trouwens ook na de opheffing ervan bleef voor de Compagnie het belang der provinandeering aldaar ${ }^{6}$ ). We konden echter toen niet verhinderen, dat de oude con-

1) Copie-instructie voor de opperhoofden van de jachten Sincapura en Klein Tholen, Batavia, 2 Juni 1622.

2) In de instructie voor den opperkoopman d.d. 2 April worden nog genoemd gezouten spek en olie.

3) Een eilandengroep tusschen Formosa en China.

4) Volgens instructie voor den betreffenden opperkoopman moet het in Patani inladen, wat proviand betreft, : rijst, olie, appelen en levend vee, vooral bokken en geiten.

5) Vg1. over de taak der vier genoemde schepen: Resolutie van G.-G. De Carpentier en Raden, Batavia, 18 Mt. 1624; Copie-instructie voor opperkoopman Jan van Hasel en de raad van de Noord-Holland, Batavia, 2 April 1624; Copie-instructie voor opperkoopman Philips Lucasz en raad van de jachten Witte Beer en West-Cappel, Batavia, 7 April 1624. De Purmerend is blijkbaar niet naar Patani geweest (Vgl. Groeneveldt, p. 261; Res. G.-G. De Carpentier en raden, Batavia, 25 Mt. 1624; idem, Batavia, 4 Mei 1624; idem, Batavia, 14 Mei 1624; idem, Batavia, 7 Juni 1624).

6) Aan Philips Lucasz, opperkoopman over de genoemde Witte Beer en West-Cappel, werd opgedragen om, bij gebrek aan voldoende peperlading voor 't hoofdkwartier, ook witte rijst in te laden (Copie-instructie voor opperkoopman Philips Lucasz en raad der jachten Witte Beer en West-Cappel, Batavia, 7 April 1624); in Maart 1625 schrijft De Carpentier, dat van Patani in Batavia met de Witte Beer drie jonken zijn aangekomen, meebrengende tezamen o.a. ongeveer 100 lasten rijst, een partij gedroogde visch, en zout. Vgl. voorts P. A. Tiele: Bouwstoffen voor de geschiedenis der Nederlanders in den Maleischen Archipel II, bewerkt door Heeres, 's-Gravenhage 1890, p. XXXII v.; Muller: Het land van den Witten Olifant, p. 130. Ook in Siam bleef onze rijsthandel. In de instructie voor Jan van Hasel, opperkoopman over het genoemde schip Noord-Holland, wordt gezinspeeld op de wijze, waarop uit Siam rijst naar 't hoofdkwartier te krijgen is. (Copie-instructie voor opperkoopman Jan van Hasel en raad van 't schip Noord-Holland, Batavia, 2 April 1624). Vgl. voorts Muller: Het land van den Witten Olifant, p. 137 v. 
currenten, de Portugeezen, zich ook met kracht hierop toelegden, en hun provisie voor Malakka uit Patani wisten te verkrijgen ${ }^{1}$ ).

$\mathrm{Na}$ het punt van de levensmiddelenvoorziening dienen de scheepsreparaties in Sangora genoemd te worden. Wel is in dit opzicht ook in Patani gewerkt ${ }^{2}$ ), maar Sangora heeft er toch een zekere bekendheid door gekregen. Kleine schepen kon men er soms wel tot dit doel binnen de rivier krijgen; met eenigszins groote schepen was het lastiger; hetzij door lagen waterstand, hetzij door wind en branding moest men ze wel ergens buiten aan de kust laten, waar het werk natuurlijk minder goed kon worden gedaan: tot de kiel toe kon men er deze schepen niet verdubbelen ${ }^{3}{ }^{4}$ ).

In 't bijzonder in 't laatste deel van haar bestaan is de factorij van Sangora voor het scheepstimmeren van beteekenis geweest. We zagen reeds, dat het jacht Klein Hollandia, in 1619 uit Jacatra gezonden, te Sangora door Chineezen werd verdubbeld ${ }^{5}$ ). Ook in het jaar 1619 werd het jacht de Morgenster afgezonden ${ }^{6}$ ). Volgens resolutie van gouverneur-generaal en raden d.d. 18 Juni diende dit jacht zeer noodig vertimmerd te worden, en zulks kon, naar vernomen was, geschikt in Sangora worden gedaan ${ }^{7}$ ). Het is echter zeer twijfelachtig, of dit gebeurd is ${ }^{8}$ ). Het in 1620 in Patani aangekomen schip de Zeewolf werd na aankomst naar Sangora gezonden ${ }^{9}$ ) om daar aan een grondige reparatie te worden onderworpen. Daar het te veel diepgang had, moest het buiten de rivier blijven: bij „Poulo Tijos" ${ }^{10}$ ), waar het zoo ver werd verdubbeld als het, in verband met zijn rankheid, mogelijk was geweest, het te

1) Tiele-Heeres : Bouwstt. II, p. XXXIII.

2) Zie: Copie-res. van 't kantoor van Patani en die van 't jacht de Pauw met de sloep van 't schip Delft, Patani, 8 Juni 1610; Gerrit Frederiksz. Druyff aan beww. kamer Amst., Patani, 26 Mt. 1619.

3) Zie p. 139 noot 1.

4) Gerrit Frederiksz. Druyff aan J. P. Coen te Jacatra, Patani, 8 Mt. 1620; Jan van Hasel aan J. P. Coen te Jacatra, Sangora, 4 Oct. 1620.

5) Zie p. 138 v.

6) Zie p. 98.

7) Copie-res. van G.-G. en Raden, in 't schip de Trouw voor Bantam, 18 Juni 1619 (Col. Coen III, p. 516 v.).

8) Later namelijk - Copiebrief van J. P. Coen aan G. F. Druyff te Patani, Jacatra, 2 Juli 1619 (Col. Coen II, p. 571 v.) - schrijft Coen aan Druyff, dat de Morgenster in Amboina of elders dient vertimmerd te worden, en draagt hij hem op, daartoe timmerlieden en materialen te leveren.

9) Zie p. 99.

10) Een eilandje, voor Sangora gelegen (in Andrees Allgemeiner Handatlas als Pulo Tikus). 
krengen $\left.{ }^{1}\right)^{2}$ ). En ten slotte weer de Morgenster. Dit jacht werd, zooals we zagen, in 1620 wederom naar Patani gezonden ${ }^{3}$ ). Het moest in Sangora worden verdubbeld, daar, gelijk Coen aan bewindhebbers schrijft ${ }^{4}$ ), te Jacatra gebrek was aan timmerlieden en zagers. Het gelukte, het jacht in de rivier van Sangora te krijgen ${ }^{5}$ ), zoodat daar de vertimmering rustig kon plaats hebben ${ }^{6}$ ).

Een gunstige omstandigheid voor dit bedrijf was, dat er in Sangora goed timmerhout in overvloed was te verkrijgen ${ }^{7}$ ), dat ook als zoodanig bij 't hoofdkwartier begeerd was. Op 15 Mei 1620 schrijft Coen dan ook aan Van Hasel, factorijhouder in Sangora, dat er korten tijd daarna zooveel mogelijk schepen zullen worden gezonden om niet alleen rijst, maar ook hout te verkrijgen ${ }^{8}$ ). Van Hasel antwoordt hierop ${ }^{9}$ ), dat Coen zich van deze houtleverantie niet al te veel moet voorstellen: weliswaar is het hout in de buurt van Sangora ruimschoots en in goede kwaliteit te krijgen, maar het ontbreekt aan timmerlieden en zagers, om het uit 't bosch te halen. Wel is er voldoende voor de normale verdubbeling van schepen. Hij hoopt bovendien, dat er hout zal geladen worden in de Morgenster. Dit is waarschijnlijk ook gebeurd ${ }^{10}$ ).

Plotseling, in 1621, wordt in Batavia het scheepstimmerbedrijf in Sangora overbodig gevonden. De verdubbeling en reparatie van schepen, die in Japan, Sangora en elders plaats vindt, zoo lezen we in een brief aan bewindhebbers ${ }^{11}$ ), verslindt veel geld, terwijl het werk niet goed en duurzaam blijkt, in 't bijzonder het verdubbelen in Japan. Daarom is het plan, dit bedrijf overal buiten 't hoofdkantoor te doen staken en het alleen in Batavia te doen uitoefenen. Een typische uiting van Coen's centralisatiepolitiek !

Ook volk uit de bocht van Patani wilde Coen naar 't hoofdkwartier trekken. Weliswaar had de gouverneur-generaal het liefst Chineezen,

1) D.i. ver overzij halen en van onderen reinigen van dierlijke en plantaardige aangroeisels.

2) Jan van Hasel aan J. P. Coen te Jacatra, Sangora, 4 Oct. 1620; Gerrit Frederiksz. Druyff aan J. P. Coen, Patani, 4 Nov. 1620.

3) Zie p. 100 , ook noot 2 aldaar.

4) J. P. Coen c.s. aan beww., Jacatra, 31 Juli 1620 (Col. Coen I, p. 560 v.).

5) Jan van Hasel aan J. P. Coen te Jacatra, Sangora, 4 Oct. 1620.

6) J. P. Coen c.s. aan beww., Jacatra, 8 Jan. 1621 (Col. Coen I, p. 606 v.).

7) Gerrit Frederiksz. Druyff aan J. P. Coen te Jacatra, Patani, 8 Mt. 1620.

8) Copiebrief van J. P. Coen aan Van Hasel te Sangora, Jacatra, $15 \mathrm{Mei}$

1620 (Col. Coen II, p. 713).

9) Brief, genoemd in noot 5 .

10) Vgl.: Gerrit Frederiksz. Druyff aan J. P. Coen, Patani, 4 Nov. 1620.

11) J. P. Coen c.s. aan beww., Batavia, 16 Nov. 1621 (Col. Coen I, p. 641 v.). 
zooals we boven zagen ${ }^{1}$ ), maar ook anderen waren welkom, slaven zoowel als vrije lieden, gehuwden en ongehuwden, ten deele om het snel opkomende Jacatra te helpen bevolken, ten deele ook om naar Amboina, Banda en Batjan te worden gezonden als visschers en ambachtslieden, inzonderheid timmerlui en houtzagers ${ }^{2}$ ).

Tenslotte moet ik nog melding maken van een merkwaardig denkbeeld, waardoor Patani voor de Compagnie groote monetaire beteekenis had kunnen krijgen. We dragen hiervan kennis door een brief, dien Laurens Reael van Ternate in 1615 aan bewindhebbers schreef ${ }^{3}$ ). „Daer wert oock voorgeslagen”, aldus Reael, ,om van Ciams goudt te Patanij ofte Jhoor ${ }^{4}$ ) een seeckere munte van masen ${ }^{5}$ ) te formeren, daer van een ider maes aen de Compagnie nae haer calculatie soude comen te bedragen 29 stuijvers 12 penningen, die men alhier in de Moluques in treijn ${ }^{6}$ ) soude moeten brengen, om te besteden tot een reael van $8^{\mathrm{e}}$ het stuck, daer uijt dat se meenen, dat behalven de avance, die de Compangnie op het goudt souwde genieten", (een reaal gold ongeveer 48 stuivers!) ,oock dit soude volgen, dat de vremdelingen wt de Moluques souden blijven, moetende haer retour ${ }^{7}$ ) in masen wederomme nemen, daer aen sij grootelijcx op de custe van Java ende elders souden moeten verliesen". Een ongehoorde mogelijkheid tot 't maken van extra-winst ! Maar Reael verklaart, dit voorstel niet geheel te kunnen ,inproberen": hij betwijfelt, of het verlies, dat de vreemdelingen op de maesen zouden lijden, hun den lust tot den handel zou benemen; waar ze wel $200,300 \%$ winst plachten te maken, ja soms nog veel meer, zouden ze hierdoor rijkelijk compensatie krijgen. En verder voorziet Reael voor de Hollanders inconveniënten als gevolg van de voorgestelde verandering. Deze zal dan ook wel niet plaats hebben gevonden; wat althans Patani betreft, heb ik er verder geen enkel gegeven over aangetroffen.

1) Zie p. $140 \mathrm{v}$.

2) Copiebrief van J. P. Coen aan C. van Nieuwenroode te Ajudhja, Jacatra, 2 Juli 1619 (Col. Coen II, p. 573) ; Copie-instructie van J. P. Coen aan kommandeur Hendrik Janssen en raad der schepen Engel, Bergerboot, Morgenster en Jager, Jacatra, 2 Juli 1619 (Col. Coen II, p. 575) ; Copiebrief van J. P. Coen aan G. F. Druyff te Patani, Jacatra, 15 Mei 1620 (Col. Coen II, p. 707 v.); Copiebrief van J. P. Coen aan G. F. Druyff te Patani, Jacatra, 3 Juli 1620.

3) Laurens Reael aan beww., Maleye op Ternate, 25 Juli 1615.

4) $=$ Johor.

5) Vgl. p. 19 noot 2 .

6) Omloop.

7) Dit is dus blijkbaar de betaling voor wat ze daar verkoopen. 


\section{ZESDE HOOFDSTUK.}

\section{Patani als politieke en economische factor van de Compagnie.}

Ik ben begonnen met stichting en geschiedenis van de factorij te Patani in haar chronologisch verloop te schetsen. Daarop moest volgen een meer gedetailleerde uiteenzetting over de verschillende handelsdoeleinden, die de Hollanders er najaagden. Als aanvulling hierop lijkt het me nu noodzakelijk, het belang van Patani tot zijn ware verhoudingen terug te brengen, d.w.z. de relatieve waarde ervan in 't kader van het algemeene Compagniesbestel nader aan te duiden. Hierbij zal ik uit den aard der zaak meermalen punten moeten aanroeren, die reeds in het chronologische verband ter sprake kwamen. Daar ze echter in nieuwen samenhang worden gebracht, moge men mij deze herhalingen vergeven.

In het begin, in den tijd der voorcompagnieën, werden wat we zouden kunnen noemen de Noorderkwartieren van zeer groot belang geacht. Van Neck en Heemskerck prijzen als om strijd de geschiktheid van Patani als handelsplaats, al vindt de laatste ook, dat zij eenigszins afgelegen is ${ }^{1}$ ). Johor, zegt hij, zou zoowel boven Patani als Bantam te verkiezen zijn, maar Malakka - toen in handen der Portugeezen zou alle drie nog te boven gaan ${ }^{2}$ ).

Het allermeest kwamen de Noorderkwartieren op den voorgrond, toen Van der Hagen in 1603 zijn tocht naar Indië ondernam. Het was toen, gelijk we zagen, de bedoeling van bewindhebbers, twee gelijkwaardige steunpunten voor den handel te stichten: Bantam en Patani, ieder met een opperkoopman en twaalf assistenten $\left.{ }^{3}\right)$. We weten, dat het in de bedoeling heeft gelegen, dat het hoofd van het Bantamsche kantoor zou letten op de „Groote Oost”, terwijl van Patani uit de handel op de Noorderkwartieren moest worden behartigd ${ }^{4}$ ). Toen Matelief in 1605 naar Indië vertrok, bestond de

1) Zie p. 14 v.

2) Jacop Heemskerck aan beww., in 't schip de Witte Leeuw, 27 Aug. 1603 (Loketkast S.-G., afd. Processen $n^{\circ}$ 21).

3) Zie p. 27 v.

4) Resolutiën der XVII van 7-12 Aug. 1603. 
gunstige meening van Heeren XVII over Patani nog onverzwakt voort: hij kreeg immers opdracht on na te gaan, of de personen, waarvan men dacht, dat ze volgens opdracht in Bantam en Patani in functie zouden zijn, behoorlijk hun plicht deden ${ }^{1}$ ). Wel weten we, dat de lastgeving aan Van der Hagen, wat Patani betreft, niet in vervulling was gegaan ${ }^{2}$ ), en dat Matelief het belang van het kantoor zeer gering achtte ${ }^{3}$ ). Maar bewindhebbers dachten er anders over ${ }^{4}$ ). Omstreeks 1607 is, zoo lezen we bij Van Dam ${ }^{5}$ ), het kantoor „,van soodanige aghtinge geweest, dat gemeynt wiert, oock d'ordre daartoe lagh, dat men den handel van Bantam daar soude trecken". Het was het jaar, waarin de vloot van Verhoeff vertrok: in de instructie daarvoor wordt Patani ook wederom ruim met personeel bedacht: men zal er laten: ,Jacob de Bitter, opperkoopman. en Jacob van Scharlaken, ondercommies; Jacob van der Dussen ${ }^{6}$ ) van Delft, Cornelis van Vlieroot ${ }^{7}$ ), juwelier, en d' assistenten Jan van Scharlaken, assistent en kuyper; voorts soo veel assistenten van d'andere schepen, als nevens de volgende sullen van noden wesen; Willem Claasz. ${ }^{8}$ ), sydecramer en assistent" $\left.{ }^{9}\right)$. In een memorie, eveneens voor Verhoeff bestemd ${ }^{10}$ ), komt verder een passage voor over het an land laten van allerlei behoeften ,,in de plaetsen van Bantam, Patana ende elders", wel een bewijs, hoe ook toen de tweeëenheid Bantam-Patani nog voortbestond.

De vraag komt daardoor vanzelf op, of Patani nog kans heeft gehad, te worden verheven tot algemeen rendez-vous, en, sedert de benoeming van Pieter Both, tot residentie van den gouverneurgeneraal. Hierover nu is nooit ernstig gedacht ${ }^{11}$ ), wèl in ruimeren

1) Zie p. 36. Een aardige bijzonderheid, die in dezelfde richting wijst, is, dat hij te Bantam en Patani bakovens moest laten maken om het brood te ,voerluchten ende voerverschen" (= verluchten en ververschen) (Copie van het verzeilen van de vloot van Matelief, bedoeld op p. 28 noot 3 ).

2) Zie p. 28.

3) Zie p. 39 en 158

4) Zie p. 41 .

5) II I, p. 326.

6) Lees: Adriaen van der Dussen.

7) Lees: Cornelis van Steenroot.

8) Vg1. p. 125.

9) Zie Van Dam I I, p. 584 v., met de door den uitgever Dr. Stapel aangebrachte correcties.

10) Memorie voor Pieter Willemss. Verhouven, vice-adm. en brede raad (Kol. Aanwinsten 1910, XV, no 1).

11) Wieder (III, p. 37) heeft een tegengestelde overtuiging, waarmee ik echter, na zorgvuldige vergelijking der beschikbare gegevens, niet kan instemmen. 
zin over het vestigen van de algemeene hoofdplaats in de Noorderkwartieren. Zoo was Both opgedragen, o.a. de geschiktheid van Johor als zoodanig te toetsen ${ }^{1}$ ). En inderdaad: de ligging van Johor was voor de scheepvaart gunstiger dan die van Patani, dat meer excentrisch lag, het bezwaar van Heemskerck.

Onder Both is, gelijk men weet, de beslissing niet gevallen. Coen, voor wien dit punt van 't hoogste belang is, weifelt. Eerst was hij voor Banka; later overwoog hij de keuze tusschen een punt op WestJavà en Malakka. Eigenlijk prefereerde hij de laatstgenoemde stad, al zou die eerst nog moeten worden veroverd; ten slotte echter viel zijn keus op Jacatra. De doorslag was gegeven door de oneenigheid met de Engelschen te Bantam omtrent den peperhandel. Van Jacatra uit kon men met kracht tegen hen optreden: dáár verrees dan ook, na allerlei wederwaardigheden, Batavia ${ }^{2}$ ). De Noorderkwartieren waren hierdoor met beslistheid op het tweede plan geschoven: Patani zou daarvan de gevolgen ondervinden.

Maar al heeft het kantoor van Patani zijn hoogen rang ten aanzien van ,ommeslag” en bestuursorganisatie van de Compagnie niet kunnen behouden, voor de Noorderkwartieren was en bleef het tijdens zijn bestaan toch het belangrijke hoofdpunt. Dat het zeggingschap over de factorij te Sangora had, spreekt eigenlijk vanzelf : immers deze was van Patani uit als een soort hulpkantoor gesticht. Teekenend is in dit opzicht een schrijven van Coen uit 1617 aan Cornelis van Nieuwenroode, opperkoopman te Sangora ${ }^{3}$ ). Coen verklaart hierin, een lading, welke door Van Nieuwenroode was gekocht, te hebben ontvangen, en daarvoor het kantoor van Patani te hebben gecrediteerd.

Maar ook het kantoor te Ajudhja stond zeer beslist onder dat van Patani, dat immers ook de hoofdrol bij 't ontstaan van onze betrekkingen met Siam gespeeld had. Het stond bij de Compagnie in dit opzicht precies omgekeerd als bij de inlandsch-staatkundige verhoudingen : het staatje Patani was, zooals we in 't eerste hoofdstuk zagen, leenplichtig aan den koning van Siam; voor de Compagnie was het kantoor in Siam onderhoorig aan dat van Patani. We weten, dat, in ieder geval van de laatste bestuursperiode van Hendrik Janssen af, de factorijhouder van Patani den titel voerde van Directeur over

1) Netscher: Djohor en Siak, p. 28.

2) Vgl. Elias II, p. 31 v.; J. P. Coen aan beww., Bantam, 10 Oct. 1616 (Col. Coen I, p. 191 v.).

3) Copiebrief van J. P. Coen aan C. van Nieuwenroode te Sangora, Jacatra, 17 April 1617 (Col. Coen II, p. 230). 
't genoemde kantoor, Sangora en Siam ${ }^{1}$ ). Deze titel volgde in de ambtelijke hiërarchie op dien van gouverneur, en werd, evenals de titel president, gebruikt daar, waar de Compagnie geen eigen grondbezit had, maar slechts handelskantoren, waarvan dan een kleiner of grooter aantal onder zoodanigen Directeur stond ${ }^{2}$ ). Deze zeggingschap over 't kantoor in Siam blijkt op allerlei wijzen. Zoo had Patani 't recht, de factorijhouders in Ajudhja te benoemen, en hun salaris te bepalen, natuurlijk alles onder „,correctie” van de Hooge Regeering. Reeds is b.v. meegedeeld ${ }^{3}$ ), hoe Lambert Jacobsz. Heyn, het hoofd van 't kantoor in Siam, in 1610 in een schrijven aan Victor Sprinckel had te kennen gegeven, nog wel voor een nieuwe dienstperiode te vinden te zijn, als Sprinckel met zijn raad zou kunnen besluiten, zijn gage te verhoogen, hoe hij in September dit verzoek herhaalde, maar dat men in Patani hierop niet inging, doch Heyn verving door Cornelis van Nieuwenroode en Marten Houtman. Ook zien we, dat Siam rekenplichtig is aan Patani. Toen bijvoorbeeld Heyn in Februari 1608 naar Siam gezonden werd ${ }^{4}$ ), om dit kantoor te besturen, bevatte de instructie, hem door Sprinckel meegegeven, de verplichting, twee maal per jaar een extract van zijn journaal en verrichte handelstransacties naar Patani op te zenden ${ }^{5}$ ). En toen in 1612 Van Nieuwenroode uit Siam naar Patani ging ${ }^{6}$ ), bracht hij alle rekeningen mede, die door Houtman en hem waren gehouden tot op ultimo Augustus ${ }^{7}$ ). Verder oefende het kantoor van Patani contrôle uit over den handel, die in Siam werd gedreven, en greep het, zoo 't noodig scheen, in. Zoo gaf Sprinckel in 1610 aan Heyn het bevel ${ }^{8}$ ), tot nader order het koopen van hertevellen en andere voor

1) J. P. Coen aan beww., Jacatra, 24 Juni 1618 (Col. Coen I, p. 335 v.); Copiebrief van Gerrit Frederiksz. Druyff aan beww., Patani, 1 Nov. 1618; Copie-attestatie en verklaring door de opperhoofden van de $\mathrm{Z}$ warte Leeuw, hoe 't schip door de Engelschen genomen is.

2) G. C. Klerk de Reus: Geschichtlicher Ueberblick der administrativen, rechtlichen und finanziellen Entwicklung der Niederländisch-Ostindischen Compagnie (Verhandelingen Bataviaasch genootschap van kunsten en wetenschappen, deel XLVII, Batavia-Solo en 's-Hage, 1894, p. 125 v.

3) Zie p. 60.

4) Zie p. 45.

5) Instructie voor Lambert Jacobsz. Heyn en zijn assistenten, Patani, 1 Febr. 1608; vgl. ook: Copiebrief van Lambert Jacobsz. Heyn aan Victor Sprinckel, Ajudhja, 26 Aug. 1608.

B) Zie p. 75 .

7) Marten Houtman aan Hendrik Janssen te Patani, Ajudhja, 20 Sept. 1612.

8) Victor Sprinckel aan Lambert Jacobsz. Heyn in Ajudhja, Patani, $16 \mathrm{Mei}$ 1610.

Verh. dl. I. 
Japan bestemde waren te ,stateren”. Dergelijke contrôle eischte vaak veel van het geduld van het Patanische opperhoofd. Men denke b.v. aan het wanbestuur van Van de Perre en Tonneman in Siam, die behalve slecht handelsbeleid ook andere zonden op hun geweten hadden ${ }^{1}$ ). In 1608 is er eenige animositeit tusschen Sprinckel en Heyn, die overigens door Sprinckel geprezen wordt. Heyn had gevonden, dat zijn chef hem ,,spitich” had geschreven. Volkomen terecht, antwoordt hierop Sprinckel, ,'t ys om sijn patientie te gemissen, yet wt de logie te draghen sonder daervan kennisse te gegeven ${ }^{2}$ ), naedemael ick daer mede ${ }^{3}$ ) belast ben" ${ }^{4}$ ). En in 't zelfde schrijven: het staat $U$ voortaan niet vrij, ,eenighe goederen ter $^{5}$ ) senden buijten de stadt van Judea ${ }^{6}$ ) om te vercoopen"; dit laatste schreef Sprinckel volgens orders, die hij van hoogerhand had ontvangen. In 1617 wordt er over geklaagd, dat door Houtman goud, zijde en andere waren, voor ' $t$ vaderland dienstig, naar Japan zijn gezonden, in strijd met de order, die hij uit Patani ontvangen had ${ }^{7}$ ). Het toezicht op Siam bracht aldus vrij wat meer zorgen mee dan dat op Sangora; stellig was ook de grootere afstand hierop van invloed: men bedenke, dat Patani en Ajudhja verder van elkaar verwijderd lagen dan Batavia en Soerabaja.

Maar ook in streken, buiten de „Directie” in strikten zin gelegen, heeft Patani invloed uitgeoefend bij ' $t$ stichten van factorijen en ' $t$ aanknoopen van nieuwe handelsbetrekkingen. We zagen b.v., dat dit met Cambodja het geval was. Reeds in 1609, tijdens de tweede aanwezigheid van de Roode Leeuw met Pijlen en de Griffioen voor Patani, werd tot een poging tot vestiging besloten: de onderkoopman Henricq van Raeij en de assistent Hans Baillij zouden, zoodra het noodige kapitaal uit Bantam gekomen was, erheen vertrekken $\left.{ }^{8}\right)$. Doordat dit kapitaal echter niet kwam, ging de vestiging in Cambodja voorloopig niet $\left.\operatorname{door}^{9}\right)$. Maar de aandacht bleef er in 't vervolg op gevestigd. In een prijscourant van 1617, in Patani opge-

1) Vgl. p. 45 v.

2) Lees: geven.

3) Namelijk met de opperste contrôle over Siam.

4) Victor Sprinckel aan Lambert (Jacobsz. Heyn?), Patani, 20 Juli 1608.

5) Moet zijn: te.

6) Ajudhja.

7) Copie-resolutiën, genomen te Patani door de raadspersonen van 't kantoor en de schepen Zwarte Leeuw en Galjas, Patani, 26 Mei 1617.

8) Zie p. 50 v.

9) Zie p. 51 v. 
maakt ${ }^{1}$ ), wordt wederom de nadruk gelegd op den voordeeligen handel in benzoë, die er te doen zou zijn, terwijl als nevenartikelen cardamon, ,gittamudidu” ${ }^{2}$ ), hertevellen en andere koopwaren zouden kunnen verkregen worden. De handel op Cambodja werd, mede volgens deze prijscourant, reeds geregeld jaarlijks door inlandsche kooplieden uit Patani gedreven. Later, in 1620, tijdens het bewind van Druyff, is dan, zooals we weten ${ }^{3}$ ), inderdaad de stichting van een factorij in Cambodja van Patani uitgegaan.

Ook van het verderop gelegen Cochinchina was toen reeds werk gemaakt, het land, waar men gemakkelijker met de Chineezen dacht te kunnen handelen dan in Patani. Vooral Coen interesseerde zich zeer voor deze nieuwe handelsoriënteering. We weten, dat het hier niet tot vestiging is gekomen, maar dat Patani het grootste aandeel had in de pogingen, die ertoe gedaan werden ${ }^{4}$ ).

Het meest eervolle gedeelte van de uitbreiding der handelssfeer van de Compagnie werd echter gevormd door de rol, die Patani in onze betrekkingen tot Japan speelde, een kantoor, dat in den loop der tijden zoo enorme winsten zou afwerpen. Reeds vroeg had Patani, zijns ondanks, met Japan te maken gekregen, doordat tijdens het bewind van Ferdinand Michiels in 1605 Jacob Jansz. Quaeckernaeck en Melchior van Santvoort in een jonk voor deze stad verschenen, gekomen uit Japan, waar door den keizer aan de Nederlanders vrije handel was toegestaan ${ }^{5}$ ). Men kan dus niet zeggen, dat Patani toen meegewerkt had tot onze eerste betrekkingen met Japan, betrekkingen, die trouwens geen practische gevolgen hadden. In 1608 werd dit anders : in Februari van dat jaar trok Melchior van Santvoort uit Patani naar Japan met een brief van Victor Sprinckel voor den keizer, teneinde de goede betrekkingen met dien vorst te bewaren ${ }^{6}$ ). En van beslissend belang was, zooals we ook reeds zagen ${ }^{7}$ ), het volgende jaar, toen, volgens een beslissing van Verhoeff, de Roode Leeuw met Pijlen en de Griffioen, met het kantoor Patani als uitgangspunt en basis, het Nederlandsche kantoor in Hirado wisten te stichten. Nadat de Japansvaarders op hun terugreis den $21^{\text {en }}$ November

1) Prijscourant van koopmanschappen, zooals die in Patani golden in September, Patani, Sept. 1617.

2) Zeker $=$ gitta mondo.

3) Zie p. 108 v.

4) Zie p. 144 v.

5) Zie p. 30 v.

6) Zie p. 48 v.

7) Zie p. 49 v. 
1609 weer van Patani naar 't Zuiden waren vertrokken ${ }^{1}$ ), zond Sprinckel in 't laatst van 1610 nog met de Delft ${ }^{2}$ ) een copie van 't contract, met den keizer van Japan gesloten, aan de bewindhebbers van de kamer van Delft $^{3}$ ).

Beschouwden we tot dusver de belangrijke expansie naar ' $t$ NoordOosten, waarin Patani een groot aandeel had, ook in Zuid-Oostelijke richting was men actief. Ik bedoel hier onze vroegste betrekkingen tot het eiland Borneo. Dat in 1604, tijdens de aanwezigheid van Van Warwijck voor Patani, aldaar een aantal Nederlanders uit Broenei kwam met een aanbieding van den koning tot vrijen handel, heb ik reeds vroeger vermeld ${ }^{4}$ ). Het schijnt, dat inderdaad tot 1608 eenige handel op dit land gedreven werd, waarschijnlijk door onze kooplieden te Patani ${ }^{5}$ ). Later is nog eens van Broenei sprake: in 1614 schreef Hendrik Janssen aan bewindhebbers te Amsterdam ${ }^{6}$ ), dat hij een brief van den koning had ontvangen, met het verzoek, een kantoor in zijn land te stichten. Janssen's advies hierover was echter niet gunstig. De handel, dien men er zou kunnen doen, zoo schrijft hij, zou de onkosten niet goed kunnen maken. Aan den vorst liet hij dan ook onder dankzegging meedeelen, dat hij voorloopig van het aanbod geen gebruik kon maken, omdat hij er in Patani geen menschen voor kon missen, en ook geen desbetreffende order had ontvangen ${ }^{7}$ ).

Belangrijker dan Broenei werd voor de Compagnie Soekadana met den rijken diamanthandel, die daar te drijven was. Uitvoerig is reeds vroeger beschreven, hoe deze handel van Patani is uitgegaan tijdens het bewind van Ferdinand Michiels, welke, waarschijnlijk in 1606, Hans Roeff naar dit gebied zond ${ }^{8}$ ), tevens, hoe in 1607 op last van Hendrik Janssen Pieter Aertss. naar Soekadana vertrok, welke er een huis liet bouwen, een eigenmachtige daad trouwens, terwijl hij ook door zijn ergerlijk levensgedrag de verontwaardiging van Janssen en Sprinckel opwekte ${ }^{9}$ ).

Tenslotte valt nog Sambas te vermelden, waar, evenals in Soekadana,

1) Zie p. 51 .

2) Zie p. 56.

3) Copiebrief van Victor Sprinckel aan bewindhebbers kamer Delft, Patani, 31 Oct. 1610.

4) Zie p. 22.

5) Van Dijk: Borneo, p. 212.

6) Hendrik Janssen aan beww. te Amst., Patani, 20 Oct. 1614.

7) $\mathrm{Zie}$ over deze poging van den koning ook: Van Dijk: Borneo, p. 215 v.; Heeres: Hendrik Janssen, p. 118 .v.

8) Zie p. 30.

9) Zie p. 61 v. 
diamanten het gezochte artikel waren. In 1609 sloot Samuel Bloemaert, die toen de Compagnie te Soekadana vertegenwoordigde, een contract met den vorst van Sambas ${ }^{1}$ ), volgens hetwelk de diamanthandel naar diens land verlegd zou worden ${ }^{2}$ ). De Jonge ${ }^{3}$ ) ziet hierin een der vruchten van Sprinckel's activiteit. Ik kan deze meening niet deelen: ik heb Bloemaert nooit in Patani aangetroffen ${ }^{4}$ ), en verder blijkt genoemd verband ook niet in het uitvoerige relaas, dat Van Dijk, door De Jonge aangehaald ${ }^{5}$ ), van deze zaak geeft. Het eenige verband, dat ik heb aangetroffen tusschen Patani en het met Sambas gesloten contract, is, dat Victor Sprinckel in 1610 per zelfde gelegenheid als de copie van 't Japansche contract ${ }^{6}$ ) er ook een van het met Sambas geslotene aan de Delftsche bewindhebbers zond ${ }^{7}$ ).

In hoeverre had Patani nu zeggingschap over de kantoren, in wier stichting het de hand had gehad, en die niet behooren tot de Directie, waarover Hendrik Janssen het bewind voerde?

Over Borneo kunnen we kort zijn. Ik heb reeds vroeger geschreven ${ }^{8}$ ), hoe na aanvankelijk sterk medeleven en besliste invloedsuitoefening Patani zich van de Borneosche zaken teruggetrokken en de leiding aan Bantam overgelaten heeft.

Maar meer dan Borneo interesseeren ons de Noorderkwartieren. Hier zien we herhaaldelijk de bemoeiingen en het ingrijpen van Patani. En hoe kon het ook anders? Afgezien van het meerdere of mindere belang van den handel, die in deze plaats gedreven werd: zij was het uitgangspunt; voor de schepen was het geheele terrein tot en met Japan gemakkelijk samen te bevaren: het vormde van nature een economisch geheel. En nu kon men wel van Bantam of Jacatra uit gedetailleerde instructies meegeven voor alle plaatsen afzonderlijk; maar wie zou vooruit zeggen, hoe het met veiligheid, met beschikbaar personeel en met handelskansen zou staan? Veel liever maakte men dan ook, gelijk wij ook reeds gezien hebben, de instructies eenigszins soepel: in Patani konden dan, in verband met de toestanden, die men daar aantrof, meer definitieve besluiten ten opzichte van de Noorderlijker gelegen plaatsen worden genomen.

1) Zie p. 62.

2) Heeres: Corpus Dipl. I, p. 73 v.

3) Opkomst III, p. 88 v.

4) Vgl. p. 30.

5) De Jonge III, p. 302, noot 1. Zie Van Dijk: Borneo, p. 136 v.

B) Zie p. 180.

7) Copiebrief van Victor Sprinckel aan beww. kamer Delft, Patani, 31 Oct. 1610.

8) Zie p. 62. 
Dat 't Cambodjasche kantoor, hadde het langer bestaan, in hooge mate van Patani afhankelijk zou zijn geworden, is duidelijk. In die richting wijst ook nu reeds het feit, dat Druyff op 4 November 1620 aan Coen schrijft ${ }^{1}$ ), Pieter Seijs als factorijhouder in Cambodja totaal ongeschikt te vinden, terwijl hij een zekeren koopman De Milde voor dien post aanbeveelt ${ }^{2}$ ). En in den zelfden brief, iets vroeger, vraagt Druyff zoo spoedig mogelijk financieele hulp uit het hoofdkantoor, daar hij het noodig oordeelt, Cambodja tenminste met 10000 realen te voorzien.

Voor Japan geldt de beïnvloeding door Patani in mindere mate, en geen wonder: dit kantoor lag veel verder verwijderd, waardoor het aangewezen was op meerdere zelfstandigheid, die alleszins was gewettigd door de schitterende financieele resultaten, die het kantoor in den vervolge voor de Compagnie heeft opgeleverd. Toch heeft Patani ook op den Japanschen handel wel eenigen invloed geoefend. Zoo draagt Coteels van Bantam uit in 1612 aan Hendrik Janssen op, om Specx in Japan uitvoerig alle bijzonderheden omtrent den handel mee te deelen, en goede correspondentie met hem te houden ${ }^{3}$ ). In het zelfde jaar was het aan het kantoor van Patani gegeven, een werkelijk aanzienlijk cargasoen voor Japan in te schepen ${ }^{4}$ ). En ook hebben we boven reeds gezien, welk een aanzienlijke rol Patani gespeeld heeft ten opzichte van de wijze, waarop de Siameesche exportartikelen voor Japan op de meest practische wijze daarheen zouden worden vervoerd ${ }^{5}$ ). Tenslotte nog een uiting van Coen. Op 23 April 1617 schrijft deze aan Hendrik Janssen ${ }^{6}$ ), dat Specx verzocht heeft, naar Cochinchina te mogen varen, en dat hij, Coen, daar geen bezwaar tegen heeft, als Specx' boeken en rekeningen „claer” zijn. Hij gelooft evenwel niet, schrijft hij aan Janssen, dat Specx hierin zal slagen. Een lichte critiek dus, vertrouwelijk aan den factorijhouder van Patani als aan een meer gelijkstaande meegedeeld. Mogen we hieruit concludeeren tot een zekere superioriteit van dit kantoor boven Japan? Het lijkt me mogelijk, maar niet zeker: administratie en correspondentie van

1) Gerrit Frederiksz. Druyff aan J. P. Coen, Patani, 4 Nov. 1620.

2) Wellicht Willem de Milde, die in 1621 als hoofd van onze factorij te Mocha opgetreden is. (Zie mijn werk: De opkomst der Westerkwartieren van de Oost-Indische Compagnie, 's-Gravenhage 1918, p. 119).

3) Mateo Coteels aan Hendrik Janssen te Patani, Bantam, 20 Mt. 1612.

4) Zie p. 78.

5) Zie p. 86 v.

6) Copiebrief van J. P. Coen aan Hendrik Janssen te Patani, Jacatra, 23 April 1617 (Col. Coen II, p. 236 v.). 
Compagnie's dienaren toch waren allerminst gevat in het strenge keurslijf van hiërarchische vormen en conventies als die een tegenwoordig staatsbestel kenmerken. Men schreef kleurig, vaak hartstochtelijk, nam geen blad voor den mond, en hield zich niet steeds voor oogen, wie meerdere, wie mindere was.

Wat in ieder geval sterk in 't oog springt, is de bijzondere belangstelling, die men in Patani voor de andere kantoren der Noorderkwartieren heeft. We treffen deze aan bij de drie figuren, die als de hoofdpersonen onzer vestiging te beschouwen zijn, Victor Sprinckel, Hendrik Janssen en Gerrit Frederiksz. Druyff.

De eerste is bitter teleurgesteld, als 't niet naar wensch gaat met de stichting van een factorij in Cambodja voor de voorziening van Japan, waar pas de handel gevestigd is, en hij laat niet na, dit aan $1^{1}$ Hermite terdege onder 't oog te brengen ${ }^{1}$ ).

Hendrik Janssen verklaart aan Coen ${ }^{2}$ ), dat hij evenals deze van meening is, dat de Chineesche handel beter dan in Patani in een kantoor in Cochinchina zal kunnen geschieden, daar de Chineezen hier gemakkelijker kunnen komen. Wanneer men maar over contante realen beschikt, zoo schrijft hij, zullen daar stellig goede zaken gedaan kunnen worden ${ }^{3}$ ).

Druyff sluit zich bij dit oordeel van Janssen aan; we hebben reeds gezien, met welk een uitbundig enthousiasme hij de vestiging der onzen in Cochinchina aanbeveelt aan de Amsterdamsche bewindhebbers ${ }^{4}$ ). En ook de vestiging in Cambodja werd geestdriftig door Druyff voorgestaan; hij wees op den overvloed van goedkoope rijst, die er te krijgen was, evenals ook arak, boter en varkensvleesch, gezouten in potten, terwijl men er den stapel kon krijgen van benzoë, cardamonium ${ }^{5}$ ), goud en andere waren; aan Pataniërs en andere natiën zou dan deze handel belet kunnen worden ${ }^{6}$ ).

Het moge niet onvermeld blijven, dat we bij Heeres ${ }^{7}$ ) een anderen kijk zouden kunnen krijgen op deze belangstelling der Patanische factorijhouders voor nieuwe kantoren. Hendrik Janssen, aldus Heeres,

1) Zie p. 51 v.

2) Copiebrief van Hendrik Janssen aan J. P. Coen te Bantam, Patani, 25 Oct. 1617.

3) $\mathrm{Zie}$ verder over Hendrik Janssen in betrekking tot Cochinchina ook p. 144.

4) Zie p. 144.

5) Zie over cardamon p. 55 , noot 5 .

6) Gerrit Frederiksz. Druyff aan J. P. Coen te Jacatra, Patani, 8 Mt. 1620; Gerrit Frederiksz. Druyff aan J. P. Coen, Patani, 4 Nov. 1620.

7) Hendrik Janssen, p. 118 v. 
voelde, dat het kantoor van Patani, dat „om zoo te zeggen zijn schepping" was, gevaar liep te worden opgeheven. Om dezen slag nu te voorkomen, legde hij zich met ijver toe op nieuwe betrekkingen met Cochinchina en Cambodja. Volgens deze opvatting zou dus alles dienen tot veiligstelling van Patani. Ik geloof, dat we dit noch van Janssen, noch van de beide andere factorijhouders mogen aannemen: immers Janssen is een der onderteekenaars eener resolutie, die in Juni 1616 werd genomen ${ }^{1}$ ) door de raadspersonen van 't kantoor en die van 't schip de Zwarte Leeuw en 't jacht Jacatra, volgens welke de jonk de Hoop met Japansch scheepsvolk bij voortduring tusschen Japan en Siam moest varen; zoo werkte dus Janssen zelf mee, om zijn eigen kantoor in zekeren zin uit te schakelen ${ }^{2}$ ). En Druyff ging later zelfs zoo ver, dat hij, gelijk we zagen, er voor pleitte, dat het Japansche kantoor dat van Siam van kapitaal zou voorzien, daar de goederen uit Siam toch ook voor Japan bestemd waren ${ }^{3}$ ), ook al weer geen uiting, die er op wijst, dat men de positie van Patani wilde bevestigen!

Ik geloof dan ook veeleer, dat deze factorijhouders verder zagen, dat ze gevoelden, zich te bevinden in een groot handelsgebied, dat buiten Patani nog ongekende mogelijkheden van rijke winst bood, waarop ze zich verplicht gevoelden, nauwkeurig te letten.

1) Copie-res. der raadspersonen van 't kantoor en van de $Z$ warte Leeuw en de Jacatra, Patani, 21 Juni 1616.

2) Zie p. 89.

3) Zie p. $107 \mathrm{v}$. 


\section{ZEVENDE HOOFDSTUK.}

\section{Portugeezen en Engelschen.}

We zagen reeds bij verschillende gelegenheden, dat de Nederlanders in Patani in contact kwamen met de Portugeezen en de Engelschen, niet steeds tot hun genoegen. De aard dezer aanrakingen was ten opzichte van beide volken zeer verschillend.

De Portugeezen waren den onzen lang voor geweest. Hun handelsbetrekkingen met Patani dateerden reeds van 1517 of $1518^{1}$ ). Bijzonder levendig was, volgens de berichten, hun verkeer aldaar omstreeks 1540: er zouden toen niet minder dan 300 Portugeezen in de haven zijn aangetroffen ${ }^{2}$ ). En dezen werden door de inwoners gaarne gezien, daar zij er goederen uit Indië zoowel als uit Westelijker gelegen streken aanbrachten ${ }^{3}$ ). Ook heeft van Patani uit Portugeesche vaart op China bestaan ${ }^{4}$ ).

Bij de komst der Nederlanders diende Patani ook wel als proviandeeringsplaats voor Malakka, waarvoor hier hoornvee werd opgekocht ${ }^{5}$ ). - Tijdens 't bewind van Victor Sprinckel, zoo vernemen we, werden tot tweemaal toe kommiezen naar Patani gezonden om daar ossen en koeien op te koopen, welke dan vandaar over land naar Malakka gedreven werden ${ }^{6}$ ), stellig bezwaarlijke en lange tochten - Ook waren toen een aantal Portugeezen in Patani woonachtig ${ }^{7}$ ). Een bepaalde officieele vestiging bestond er echter niet, en evenmin een Portugeesche versterking; de handel was er meer incidenteel, in handen van particulieren. Wel kunnen dezen zich relatief veilig hebben gevoeld, daar aan den overkant van het schiereiland zich Malakka als dreigend machtspunt bevond ${ }^{8}$ ).

1) John Anderson, M. D.: English intercourse with Siam in the seventeenth century, London 1890, p. 44; Fr. Ch. Danvers: The Portuguese in India, London 1894, I, p. 341 v.

2) Anderson, p. 44; Tiele Eur. 4, III, p. 67.

3) Tiele 1.1 .

4) Tiele Eur. 4, IV, 305.

5) Tiele Eur. 4, VI, 179.

6) Roelof Roelofsz. (in Begin ende Voortgangh I), p. 18.

7) Tiele Eur. 4, VI, 179.

8) Zie p. 114 . 
Dat Van Neck bij zijn komst in 1601 bij de Portugeezen in Patani op een stemming van jalouzie en vijandschap stuitte, een vijandschap, die tot gevaarlijke uitbarstingen kon komen, ligt voor de hand. „Als d'Admirael Neck hier eerst quam", zoo schrijft Jan Pauwels, viceadmiraal onder Heemskerck, ,booden de Portugeesen hier aen d' overheyt voor yder Hollander een catty ghout, welcke principaele Poortugees verleên nacht in syn huys vermoort is, alle syn goet genomen. Alsoo kryghen die verraaders te mets haer loon"1). En we zagen reeds vroeger ${ }^{2}$ ), hoe 200 Japanners, die in dienst stonden van de Portugeezen, hulp zouden verleenen bij den door Siameezen beraamden aanslag tegen de Amsterdam en de Gouda in Januari 1602. Wanneer we dan ook in een informatie voor Van der Hagen over Patani de zinsnede aantreffen: „Altyts behoeft men hier geen sorge te hebben van de Portugesen" 3 ), dan is deze uiting maar tot op zekere hoogte juist.

Van groot belang was in dezen natuurlijk de houding der inlanders. De keuze was voor hen moeilijk. In hoeverre ze sympathie koesterden voor Portugeezen of Nederlanders, deze vraag zal wel vooral hebben samengehangen met de mate van handelsvoordeelen, die ieder volk beloofde, en de gewapende macht, waarmee het zijn handel zou kunnen stabiliseeren. Wat dit laatste betreft, kon het nemen van de kraak S. Catharina door Heemskerck in Februari 1603 niet zonder invloed blijven, daar deze gebeurtenis voor het dichtbijgelegen Johor geschiedde $^{4}$ ). Wanneer later in het zelfde jaar Cornelis Pietersz. met zijn schepen voor de zelfde plaats Johor een Portugeesche vloot verslaat, toonen de hoogwaardigheidsbekleeders van Patani openlijk hun belangstelling hiervoor aan den overwinnaar ${ }^{5}$ ). En dan volgt, in 1605, vlak voor Patani, het nemen van cle kraak S. Antoni door Van Warwijck $^{6}$ ). Dat hierbij de koningin een voor ons ,,welwillende neutraliteit" aan den dag gelegd had, dat zij van de onzen een schadeloosstelling had geëischt en ontvangen voor het wraakrisico, dat ze nu liep van den kant der Portugeezen ${ }^{7}$ ), dit zijn aanwijzingen van een beslist partij kiezen van de Patanische hofpolitiek ten onzen gunste. In dezelfde richting werkte natuurlijk de brandstichting in de voorstad, door Japanners

1) Postscriptum van bijlage XXIX bij De Jonge II.

2) Zie p. 7 .

3) Rouffaer en Juynboll I, bịjlage III.

4) Zie p. 12 .

5) Zie p. 18.

6) Zie p. 24

7) Zie p. 25. 
op aanstichting der Portugeezen bedreven ${ }^{1}$ ), ,,waer mede”, zoo lezen we, ,de Portugesen ende Iaponnesen hare commercie aldaer gantsch verloren hebben" ${ }^{2}$ ). Men kan gerust zeggen, dat hierna de Portugeesche invloed door den Nederlandschen verdrongen was ${ }^{3}$ ). Dat later Patani een uitgangspunt werd voor 't jacht maken op de kraken, die tusschen Macao en Nagasaki voeren, is ons bekend ${ }^{4}$ ).

In 1606, zoo hoopte men, zou Matelief de kroon op 't werk zetten, namelijk door het veroveren van Malakka. Was deze stad eenmaal in onze handen, dan zou men niet licht meer een wederopleving van het Portugeesche gevaar behoeven te vreezen. De poging van Matelief mislukte echter ${ }^{5}$ ). Het is waar, dat de uit Goa gezonden vloot, die de Portugeezen in Malakka moest steunen, door onzen admiraal werd verslagen, en dat althans dit wapenfeit een preventieve werking ten goede op de Pataniërs had. „Indien Godt de heere my de victorye tegen den vyserei niet hadde gegeven", zoo schrijft Matelief aan Van Caerden ${ }^{6}$ ), „tsoude met al onse comptoiren qualyc gestaen hebben, principael met die van Patani, want dat syn schelmen". Dat echter op deze wijze de handel der onzen in Patani niet afdoende werd beveiligd, ligt voor de hand. Het Portugeezengevaar was dan ook, gelijk wij reeds zagen, mede de oorzaak, dat het schip de Mauritius, hetwelk in 1607 de plaats bezocht, een groot deel van het kapitaal uit onze loge lichtte ${ }^{7}$ ).

Daar Malakka een voortdurend gevaar bleef opleveren, was het voor de Compagnie van uitnemend belang, dat de Portugeezen geen vastell voet konden krijgen in Johor, waardoor dit gevaar nog acuter zou worden. Talrijk zijn dan ook de pogingen geweest, om dit rijk in gunstige stemming voor ons te houden en het tot medewerking in den strijd tegen den aartsvijand op te wekken. Cornelis Pietersz. was, gelijk we zooeven zagen, in 1603 met een meer actieve politiek in dezen begonnen. Na zijn vertrek uit Johor kwamen er weer twee galeien van Malakka dreigend voor Batosauwer ${ }^{8}$ ) liggen. Maar gelukkig

1) Zie p. 25.

2) Voyage Paulus van Solt (onderdeel reis Van der Hagen in 't begin van Begin ende Voortg. II), p. 42.

3) Tiele Eur. 4, VI, p. 240.

4) Zie p. 49, verder ook hoofdstuk II d.

5) Zie p. 37 en 139.

6) Advies van den admiraal Matelief aan den admiraal Van Caerden, 4 Jan. 1608 (De Jonge III, bij1. XIV).

7) Zie p. 38.

8) Zie p. 51, noot 1 . 
weigerde de sultan, de Hollanders in deze plaats over te leveren aan den Kapitein-Majoor van Malakka, Andreas Furtado de Mendoça ${ }^{1}$ ). Van Warwijck, in 1604 op weg naar China Johor aandoende ${ }^{2}$ ), voorzag daar de Nederlanders met kruit en lood, ter verdediging tegen de Portugeezen ${ }^{3}$ ). In 1605 volgde een krachtig optreden onzerzijds, toen de Vlissingen, alvorens in Patani bij Van Warwijck te verschijnen ${ }^{4}$ ), voor Johor een Portugeesch galjoen versloeg ${ }^{5}$ ). Zelfs is Warwijck wederom in Johor geweest op zijn terugreis naar Bantam, en heeft toen met den vice-admiraal Cornelis Bastiaensz. voor de steeds bedreigde stad overleg gepleegd over de aan Johor te verleenen hulp ${ }^{6}$ ) : aan den sultan werden bij die gelegenheid vier metalen stukken en tien vaten buskruit verstrekt ${ }^{7}$ ).

In 1606 was de afloop van den strijd van Matelief voor Malakka natuurlijk ook voor Johor een levenskwestie. Alvorens dezen strijd aan te vangen, verscheen dan ook Matelief in 1606 voor Johor, en sloot er een verbond met Jang dipertoewan en Radja Saberang $\left.{ }^{8}\right)^{9}$ ), en in September, vóór den roemrijken slag, dien Matelief den Portugeezen zou leveren, volgde een tweede verbond ${ }^{10}$ ). Maar meer heeft Matelief voor Johor niet kunnen doen, terwijl daar het Portugeesche gevaar steeds bleef voortduren, en geruchten tot Bantam doordrongen, dat de vorst, den ongelijken strijd moede, en wanhopend aan voldoende Nederlandsche assistentie, over vrede met Malakka ging denken ${ }^{11}$ ). Geen wonder dan ook, dat het schip Gouda in 1608 naar 't Noorden werd gezonden, om, behalve in Patani, ook in Johor het overgroote deel van het kapitaal te lichten ${ }^{12}$ ); sloot deze laatste plaats inderdaad vrede met de Portugeezen, dan kon men in de Nederlandsche loge van niets meer zeker zijn!

1) De Jonge III, p. $18 \mathrm{v}$.

2) Zie p. 21.

3) De Jonge III, p. 23.

4) Zie p. 25 .

5) Journaal Van Warwijck (in Beg. ende Voortg. I), p. 82; De Jonge III, p. 25.

6) Zie p. 28 .

7) Journaal Van Solt (onderdeel reis V. d. Hagen in 't begin van Begin ende Voortg. II), p. 48 ; De Jonge III, p. 25 v.

8) De Jonge III, p. 48 v.; Netscher: Djohor en Siak, p. 9; Heeres: Corpus Dipl. I, p. 41 v.

9) Aan ' $t$ eind van ' $t$ contract komt de wonderlijke tweeëenheid voor: „Wij, jan de patuan en raija Sabrangh". Volgens Heeres was de eerste de vorst van Johor, de laatste een broeder, die 't bestuur met hem deelde.

10) De Jonge III, p. 49 v.; Netscher 1.1.; Heeres: Corpus Dipl. I, p. 47 v.

11) Zie p. 38.

12) Zie p. 39; De Jonge III, p. 79 v. 
De toestand in Johor werd nu uitermate nijpend. Van Victor Sprinckel, in Patani, ontving men berichten over de ,extreme miserie”, waarin de Johorieten door de nalatigheid der onzen geraakt waren: het volk in opstand, omdat het vrede met de Portugeezen wil bewerken, en geen assistentie van Nederlandsche schepen; Raga Sabran ${ }^{1}$ ) heeft in een brief aan Sprinckel bitter geklaagd: steeds heeft hij op de Nederlanders vertrouwd, ,ende nu hem laten tusschen twee stoelen in d'asschen zitten, zoo dat men dezelve niet lesen kan, sonder dat een mensche die tranen overloopen" ${ }^{2}$ ).

Een laatste kans op redding nog zou de vloot van Verhoeff brengen. Nadat deze van de straat van Malakka uit een vruchteloos beroep op den reeds niet meer voor ons betrouwbaren sultan van Johor had gedaan, ging hij in persoon derwaarts, en had er in 't begin van 1609 een samenkomst met den vorst, die echter evenmin het gewenschte resultaat had $^{3}$ ). Tijdsgebrek noopte Verhoeff, onverrichterzake te vertrekken; hij gaf echter eerst last, krijgsvoorraad en geld aan den sultan te verstrekken, en liet de Roode Leeuw met Pijlen en de Griffioen voor Johor achter onder het bevel van Abraham van den Broecke $^{4}$ ). Op 4 Mei 1609 echter ontvingen de beide schepen, zooals we zagen, een lastgeving van Verhoeff, dat ze Johor moesten verlaten, om de vestiging van onzen handel in Japan en het nemen van een Portugeesche kraak in 't oog te vatten ${ }^{5}$ ). $\mathrm{Na}$ het vertrek der schepen kwam opnieuw een Portugeesche armada pressie op den vorst van Johor uitoefenen ${ }^{6}$ ). En toen de Roode Leeuw met Pijlen en de Griffioen, na hun werk in Japan volbracht te hebben, in het laatst van 1609 opnieuw voor Johor kwamen, vonden ze de vredesonderhandelingen met de Portugeezen reeds in een al te ver gevorderd stadium om den loop der gebeurtenissen nog te kunnen stuiten, en zoo konden ze in Bantam in dit opzicht dan ook geen hoopvolle berichten brengen. Inderdaad kwam de gevreesde vrede op 16 October 1610 tot stand. En al schijnt het, dat ook daarna den Nederlanders in Johor geen overlast werd ge-

1) Radja Saberang.

2) De Jonge III, p. 80; Victor Sprinckel aan Jacques l'Hermite de Jonge te Bantam, Patani, 27 Oct. 1608 (welke brief door De Jonge, 1.1., blijkbaar ten onrechte, op 27 Dec. 1608 gedateerd wordt).

3) De Jonge III, p. 79 v.

4) De Jonge III, p. 81 v.; Van Dijk: Japan, p. 21; Tiele Eur. 4, VIII, p. $90 \mathrm{v}$.

5) Zie p. 49 .

6) De Jonge III, p. 90 . 
daan, het gevaar voor Patani was toch weer nader gerukt $\left.{ }^{1}\right)^{2}$ ).

Dat in 1609 in Europa het Twaalf jarig Bestand werd gesloten, bracht in Indië geen verlichting: men weet, dat dit verdrag ten opzichte van de vaart aldaar geen dwingende bepalingen bevatte. Zooveel mogelijk gingen de Portugeezen dan ook door, de veiligheid der onzen in de bocht van Patani te belagen, en wel door verschillende raids met roeivloten, bestaande uit kleine scheepjes, waarmee ze natuurlijk dichter tot de kust konden naderen en daar meer onheil aanrichten dan met hun groote schepen.

Nog in 1609 werd Jan Janssen van Breemen, bootsgezel uit de loge van Patani, welke door Victor Sprinckel op 15 September naar Johor en Bantam was afgezonden, het slachtoffer van een dergelijke „,armada de reme" $\left.{ }^{3}\right)^{4}$ ). Deze vloot, die moet bestaan hebben uit twee galeien, tien fusten ${ }^{5}$ ) en twintig bantins ${ }^{6}$ ), was uit Malakka vertrokken om roof te plegen aan de Oostkust van 't schiereiland, en wel met succes: bij 't eiland Redang ${ }^{7}$ ) werd een tiental jonken, ten deele, naar 't schijnt, uit Patani afkomstig, genomen en verbrand, de opvarenden of gevangengenomen of als slaven verkocht, een gebeurtenis, die in Patani begrijpelijkerwijze groote „,beroerte” wekte. In de buurt van Pahang nam de Portugeesche vloot de jonk van Jan Janssen, die gevangengenomen en naar Malakka gevoerd werd ${ }^{8}$ ).

Ook in 1613 deden de Portugeezen wederom van zich spreken; het initiatief was toen trouwens genomen door een aantal Nederlanders, die, uit Atjehsche gevangenschap ontslagen ${ }^{9}$ ), in een fust naar Malakka voeren, en daaromtrent een Portugeesch fregat namen, dat ze plun-

1) Zie p. 51 en noot 1 aldaar.

2) $\mathrm{Bij}$ De Jonge III, p. 90, lezen we, hoe Radja Saberang zich in het Hollandsche kantoor excuseerde over den vrede, zich op overmacht beriep, en verklaarde, zoo lang hij leefde, de Hollanders niet in den steek te zullen laten.

3) Roeivloot.

4) Vgl. p. 51 .

5) Kleine galeien.

6) bantin : een roeischip. Misschien $=$ binta $=$ baloer $=$ balouw, een groot roeivaartuig - dat genoemd wordt in Corpus Diplomaticum Neerlando-Indicum III (bewerkt door Dr. F. W. Stapel, Den Haag 1934), p. 203, noot 4 -?

7) Hiermee zal wel Groot-Redang bedoeld zijn, het hoofdeiland van de Redang-groep op $\pm 534^{\circ}$ N.B.

8) Zie: Res. van de raden van de Vereenigde Leeuw met Pijlen en de Griffioen, Patani, 16 Nov. 1609; Res. van 't college der Roode Leeuw met Pijlen en Griffioen, bij 't eiland Polo Tijmon, 1 Dec. 1609; idem, voor de rivier van Johor, 4 Dec. 1609; Victor Sprinckel aan Lambert Jacobsz. Heyn in Ajudhja, Patani, 30 Jan. 1610.

9) Zie p. 71 v. 
derden; de opvarenden liet men echter hun weg vervolgen. In Malakka gekomen, waarschuwden dezen den onderkoning, die drie of vier fregatten bemande, welke nu de Nederlanders opzochten, aanvielen en overwonnen. Drie lieten hierbij het leven, de overigen, waaronder ook de gewonden, werden in triomf naar Malakka gevoerd; onder deze Nederlanders waren, naar Pieter Both meent te weten, de opperkooplieden Theunemans, Boeckholt, Labestrate ${ }^{1}$ ) en Frederick Kistgens, met drie assistenten. Gruwelijke bijzonderheden ontleent Both aan de opvarenden van een Javaansche jonk, die de gevangenen in Malakka hadden gezien, en bijgewoond, ,dat daerbij een coopman uijt de gevanckenisse worde gehaelt ende van achteren doorsteecken, ende het dode lichaem als een beest langen tijdt op de straet lieten leggen omtrent het gevangenhuijs". Dit bericht werd Both bevestigd door Hendrik Janssen, die, gelijk wij reeds zagen ${ }^{2}$ ), op 13 December 1613 met de Hoop te Bantam aankwam ${ }^{3}$ ).

Ook in 1614 bleef in de buurt van Patani de druk van de Portugeesche bedreiging groot. En niet alleen door de Portugeezen, maar ook door de Atjehers werd de kust onveilig gemaakt, „,waerdoor”, gelijk Hendrik Janssen schrijft, ,elck een vreest, zyn hooft uijt te steken oft yts ter zee te rysequeeren". De zeevaart, die in Patani zoo belangrijk placht te wezen, kwam daardoor geheel stil te liggen ${ }^{4}$ ). Een middel om de Portugeezen in hun handel te benadeelen geeft Hendrik Janssen in het zelfde schrijven aan: door Siam werd, niet voor 't eerst trouwens, aan de Nederlanders het land van Mergui en Tenasserim aangeboden, liggende in 't Noorden van het schiereiland van Malakka. Als we van deze aanbieding gebruik maakten, zou dat „een deure voor der Portugeesen neuse” wezen, daar zij langs dezen overouden handelsweg van Tenasserim een levendigen handel op Siam plachten te drijven. Hendrik Janssen maakt zich echter geen illusies : de Compagnie's taak, beseft hij, is reeds te omvangrijk dan dat men voorloopig aan het bezetten van deze handelspunten zal kunnen denken ${ }^{5}$ ).

1) Deze was, naar 't schijnt, in 1613 uit Queda in Atjeh gekomen (Moreland, p. 67 v.).

2) Zie p. 74 .

3) Pieter Both aan beww., Bantam, 1 Jan. 1614.

4) Hendrik Janssen aan beww. te Amst., Patani, 20 Oct. 1614.

5) Zie brief van noot 4. Verder: Roelof Roelofsz (in Beg. ende Voortg. I), p. 22 v.; Linschoten I, p. 71; Cornelis van Nieuwenroode en Marten Houtman aan Hendrik Janssen te Patani, Ajudhja, 3 Mei 1612; Prijscourant van koopmanschappen, zooals die in Patani golden in Sept. 1617, Patani, Sept. 1617. 
Ondertusschen bleef het gevaar bestaan. In 1616 werd het zelfs bijzonder levendig, doordat men nu ook voor een Spaansche scheepsmacht uit 't Oosten te vreezen had. Don Juan de Silva, gouverneur van de Philippijnen, verscheen toen in 't begin van Maart in de straat van Singapore, om zich daar te vereenigen met een vloot van den vicerey van Goa; zoo zou een zeemacht bijeen zijn, die de kantoren van Patani en Sangora geheel zou kunnen vernietigen. Uit vrees brachten de Hollanders alle contanten der beide factorijen in veiligheid op 't jacht Jacatra ${ }^{1}$ ), dat zich toen voor Patani bevond, verder ook, voor zoover de ruimte het toeliet, de beste goederen. Van de Pataniërs verwachtte men namelijk bij een Portugeesche landing weinig steun: het ontbreekt hun, aldus Hendrik Janssen, niet aan macht van volk, maar aan ,hart ende eennen goeden voorganger ofte aenvoerder". Men kwam er echter ditmaal met den schrik af : na ongeveer drie maanden tevergeefs op den vicerey te hebben gewacht, stierf Don Juan de Silva, en zijn vloot keerde daarop naar de Philippijnen terug ${ }^{2}$ ). Minder goed verging het den Nederlanders, gelijk we reeds zagen ${ }^{3}$ ), in dit jaar tegenover de Portugeezen in Cambodja.

In 1617 verzoekt Hendrik Janssen in een brief aan Coen om een klein jacht of sloep, die bij voortduring tegen de Portugeezen in de vaarwateren bij Patani moest worden gehouden: aan den Nederlandschen handel zou daarmee eindelijk een groote dienst kunnen bewezen worden, ja tot in Cambodja zou men de Portugeezen lastig kunnen vallen; waar dezen hun handel dreven met zeer ,oolijcke ende onweerbaere" scheepjes, moest het voordeel van het door Hendrik Janssen gevraagde schip wel opwegen tegen de kosten, die er op zouden vallen ${ }^{4}$ ).

In hetzelfde schrijven toont Hendrik Janssen reeds een zekere bezorgdheid, omdat er vredesplannen in de lucht hangen tusschen Pataniërs en Portugeezen. Dit gevaar was ook inderdaad groot, want de koning van Siam, leenheer over Patani, had in 1616 reeds het voorbeeld gegeven door gezanten naar Goa en Portugal te zenden ${ }^{5}$ ). Geen wonder, dat men zich in Patani ook onzeker ging voelen. In

1) Zie p. 82 .

2) Hendrik Janssen aan beww. te Amst., Patani, 25 Oct. 1616; Copiebrief van Hendrik Janssen aan J. P. Coen, Patani, 25 Oct. 1616.

3) $\mathrm{Zie}$ p. 108 noot 5.

4) Copiebrief van Hendrik Janssen aan J. P. Coen te Bantam, Patani, 25 Oct. 1617.

5) Zie p. 114 . 
verband hiermee verdient vermelding, dat in October 1617 een Portugeesch vaartuig ${ }^{1}$ ), dat op roof uit geweest was, door prauwen van de koningin van Patani naar deze stad gebracht werd; de opvarenden, 8 blanken en 40 zwarten, werden eerst goed behandeld, maar naderhand gevangen gezet. Twee van de blanken werden daarna los gelaten en naar Malakka gezonden, mogelijk, zoo denkt Hendrik Janssen, om daar den vrede te bevorderen. De achterblijvenden konden dan natuurlijk, als gijzelaars, een krachtig argument vormen voor ' $t$ verkrijgen van gunstige voorwaarden ${ }^{2}$ ). Coen schrijft in December 1617 over deze vredesonderhandelingen als een zeker feit aan bewindhebbers ${ }^{3}$ ), toont echter in Maart van het volgende jaar in een schrijven aan Hendrik Janssen, dat hij nog niet alle hoop heeft opgegeven, dat de onderhandelingen zonder resultaat zullen eindigen ${ }^{4}$ ).

Deze hoop zou ijdel blijken : het sluiten van den vrede was niet tegen te houden ${ }^{5}$ ). Wanneer hij definitief tot stand kwam, is niet na te gaan; in ieder geval was hij een feit op 4 October 1618, wanneer Druyff er aan de bewindhebbers over schrijft ${ }^{6}$ ). Coen's houding ten aanzien van dezen neteligen toestand is eerst voorzichtig: in Juli 1619 schrijft hij aan de koningin van Patani, den tot stand gekomen vrede weliswaar te betreuren, maar toch order te hebben gegeven, Patanische jonken, welke in de buurt van die stad zouden worden aangetroffen, niet lastig te vallen, maar daarentegen alle vriendschap te bewijzen ${ }^{7}$ ). Door zachtheid, zoo hoopte hij waarschijnlijk, zou de handel ter zee met Malakka licht nog, zoo niet geheel verhinderd, dan toch getemperd kunnen worden. Doch dit bleek niet het geval te zijn : we zagen reeds, hoe de koningin in 1620 door een gezant aan Coen liet verzoeken om geen Portugeesche schepen, die op Patani handel dreven, lastig te vallen, en ook niet die Patanische jonken, die de uitgesproken bedoeling hadden, op de Molukken of op Malakka met de Portugeezen te handelen. Coen, we merkten het ook reeds op, was niet geneigd, de welwillendheid zoo ver uit te strekken; daar hij geen

1) Naar het mij schijnt, een tjulgia genoemd, een vorm, dien ik niet verklaren kan.

2) Copiebrief van Hendrik Janssen aan J. P. Coen te Bantam, Patani, 25 Oct. 1617.

3) J. P. Coen aan beww., Bantam, 18 Dec. 1617 (Col. Coen I, p. 290 v.).

4) Copiebrief van J. P. Coen aan Hendrik Janssen te Patani, in 't schip Zierikzee, liggend aan de eilanden van Jacatra, 30 Mt. 1618 (Col. Coen II, p. 360 v.).

5) Zie p. 114.

6) Copiebrief van Gerrit Frederiksz. Druyff aan beww., Patani, 4 Oct. 1618.

7) Copiebrief van J. P. Coen aan de koningin van Patani, Jacatra, 2 Juli 1619 (Col. Coen II, p. 573 v.).

Verh. di. I. 
onderbreking in het bestrijden van den landsvijand wenschte, sloeg hij het verzoek rondweg af ${ }^{1}$ ).

Ondertusschen was het aantal Portugeezen in Patani voortdurend toegenomen. Druyff bericht in Maart 1619, dat er dan, met inbegrip van hun slaven, reeds meer dan honderd gevestigd zijn. Hun hoofd, Joan Cardossa de Sosia, staat bij de koningin in hooge eere. $\mathrm{Z}_{\mathrm{ij}}$ heeft hem begiftigd met een gouden kris en met een Maleisch kostuum, waar hij dagelijks ,als een groten narre mede loopt”. Hij bewijst dan ook aan de inlanders belangrijke diensten: dagelijks geeft hij hun onderricht in het schieten met geschut en musketten. De andere Portugeezen mogen dan al, om met Druyff te spreken, grootendeels „,caele verckens” zijn, hun aanwezigheid is toch voor de Hollandsche factorijhouders alles behalve geruststellend ${ }^{2}$ ).

Dat de kusten bij Patani door de Portugeezen meer dan ooit onveilig gemaakt werden, spreekt vanzelf ${ }^{3}$ ). Nieuwe verweermiddelen van onzen kant werden dringend noodzakelijk. Als zoodanig zond Druyff op 10 Maart 1619 een galei of ,gorap" uit, bemand met tien Hollanders en vier Maleiers, en bewapend met vier steenstukken ${ }^{4}$ ), vier bassen ${ }^{5}$ ) en voorts musketten, om de aankomst van een in Ligor verwachte jonk te beveiligen ${ }^{6}$ ). Verder bracht het jacht Klein Hollandia, dat 2 Juni 1619 uit Jacatra naar Patani gezonden werd, opluchting ${ }^{7}$ ). Ook het Vosje, welk jacht op 15 of 17 Februari 1620 onverwacht voor Patani verscheen ${ }^{8}$ ), was zeer welkom, omdat het eveneens de aankomst van jonken in Ligor zou kunnen beveiligen ${ }^{9}$ ). Verder gaf de nieuwe steenen ,godong" met de beide rondeeltjes in Sangora, mits van een goed aantal verdedigers voorzien, een goede beveiliging tegen de Portugeezen, gelijk wij reeds zagen ${ }^{\mathbf{1 0}}$ ).

Behalve militaire problemen veroorzaakt de versterkte komst der Portugeezen vooral ook handelsmoeilijkheden. Druyff moet het aan-

1) Zie p. 114 v.

2) Gerrit Frederiksz. Druyff aan beww. kamer Amst., Patani, 26 Mt. 1619. Zie ook Tiele Eur. 5, II, p. 242.

3) Zie p. 114 .

4) Kleine ijzeren gegoten kanonnen, waarmee vroeger steenen kogels werden geschoten. Zie: De eerste schipvaart, uitg. G. P. Rouffaer en J. W. IJzerman I (Linsch. Ver VII), p. XXXIII, noot 9.

5) Bas: een licht kanonnetje.

6) Zie den in noot 2 genoemden brief.

7) Zie p. 98 en 114 v.

8) Zie p. 99.

9) Gerrit Frederiksz. Druyff aan J. P. Coen te Jacatra, Patani, 8 Mt. 1620.

10) Zie p. 106 v. 
zien, dat ze de geheele omgeving zoodanig met kleedjes overstroomen, en die zoo goedkoop leveren, dat de Nederlanders niet tegen hen kunnen „merckten" ${ }^{1}$ ). In 1620 schrijft hij aan Coen, dat ze op listige wijze de tol ontduiken, door bij iedere lading kleeden, die ze aanbrengen, een brief gereed te hebben aan de overheid, welke brief dan uit Malakka afkomstig heet te zijn; al is de inhoud ook volkomen uit den duim gezogen, zij doen zich daarmee voor als ,orang ontissang” ${ }^{2}$ ), en genieten als zoodanig volkomen tolvrijheid ${ }^{3}$ ).

$\mathrm{Na}$ de opheffing van ons kantoor in Patani ${ }^{4}$ ) kregen de Portugeezen daar natuurlijk nog meer vrij spel: hun belangen waren daar toen zeer groot, zoo voor den afzet van kleeden als ook voor de proviandeering van Malakka ${ }^{5}$ ).

Van geheel anderen aard was onze verhouding tot de Engelschen. Hier geen oorlogstoestand, geen openlijke strijd - althans niet in 't begin. De vriendschappelijke verhouding tusschen de beide landen bracht mee, dat men elkaar ook in de koloniën verdroeg, ja met voorkomendheid behandelde. Hatelijk in commercieel opzicht was het echter soms voor de onzen, dat op punten, waar zij met veel moeite toegang en handel hadden verworven, de Engelschen zich iets later met veel minder bezwaar vestigden, als ' $t$ ware in de schaduw van de Hollanders, om aldus op gelijke wijze van de winstmogelijkheden te profiteeren.

Ook in Patani waren de ",geveinsde vrienden” verschenen, en wel, gelijk wij zagen, op 2 Juli 1612, toen het schip de Globe ter reede kwam $^{6}$ ). De beide kooplieden, die de commercieele leiding van den tocht hadden. Peter Floris en Lucas Antheunis, waren, zooals ik reeds opmerkte, Nederlanders. Beiden hadden vroeger onze Compagnie aan de kust van Koromandel gediend, echter onder eenigszins andere namen, te weten Pieter Willemsz. en Lucas Janssen. De eerste was onderkoopman in Masulipatam geweest ${ }^{7}$ ), de laatste had aan 't

1) Copiebrief van Gerrit Frederiksz. Druyff aan beww., Patani, 4 Oct. 1618.

2) Mal. oetoesan: gezant.

3) Gerrit Frederiksz. Druyff aan J. P. Coen, Patani, 4 Nov. 1620.

4) Zie hoofdstuk VIII.

5) Tiele-Heeres: Bouwstoffen II, p. XXXIII; Generale missive van Pieter de Carpentier c.s. aan beww., Batavia, 27 Jan. 1625.

6) $\mathrm{Zie}$ p. $70 \mathrm{v}$.

7) Zie mijn proefschrift over Koromandel, p. 36. 
hoofd van 't kantoor van Petapoelie gestaan ${ }^{1}{ }^{2}$ ). Toen de Globe voor Patani was gearriveerd, kwam een drietal Nederlanders aan boord, „of whome”, zoo vertelt Peter Floris, ,wee learned the manners and custome of the countrie". Het kwam er nu op aan, zich zoo spoedig mogelijk met het hof in verbinding te stellen, en den meegebrachten brief van koning Jacobus van Engeland, vergezeld van de gebruikelijke schenkage, aan de koningin van Patani te doen toekomen. Toen deze brief aan 't strand was gebracht -6 Juli -, werden de Engelschen naar 's lands wijze op decoratieve manier ingehaald: „the letter, being layde in a bason of golde, was carryed uppon an elephant, with minstrells and a good many lances and little flaggs". Al kreeg men ook bij deze gelegenheid de koningin zelf niet te zien, de vrije handel werd den Engelschen gegarandeerd tegen betaling van de rechten van 't land, op denzelfden voet als de Hollanders deden. Daar de Engelschen nog geen onderdak hadden, maakten ze gebruik van de invitatie van Hendrik Janssen, den volgenden nacht in diens huis te logeeren.

$\mathrm{Na}$ veel moeite kregen de Engelschen verlof, vlak bij het Hollandsche huis een pakhuis te bouwen; bij nadere overweging van de lasten, die ze zouden hebben te betalen, hadden ze nog geaarzeld, daar de zwaarte hiervan het voordeel van den handel problematisch scheen te maken. Ze hadden echter, hoewel met weerzin, toegestemd. De Engelschen werden, in afwachting van de voltooiing der nieuwe loge, voorloopig in twee gehuurde huizen ondergebracht, waarvan het eene was bestemd voor de zieken, die er in maar al te grooten getale waren. 19 Juli viel als slachtoffer van dysenterie een der voornaamste personen van de expeditie, namelijk kapitein Hippon, „our good shepherd, that wise and worthy gentleman", zooals Adam Denton, een der meegekomen kooplieden, zich uitdrukt. Vier dagen later werd Thomas Essington tot opvolger van hem aangesteld, en John Johnson tot stuurman onder hem. Toen het huis der Engelschen klaar was, werd op 11 Augustus besloten, zoodanige kleedjes uit het schip hierin te brengen, als men dacht, in Patani het gemakkelijkst aan den man te zullen kunnen brengen, en daarna vertrok de Globe, de nieuwe factorij onder 't gezag van Peter Floris als hoofd van acht Engelschen achterlatende, op 14 Augustus naar Siam. Lucas 'Antheunis bevond zich onder de opvarenden ${ }^{3}$ ).

1) Op. cit. p. 53.

2) Een zeer grondige beschouwing omtrent de redenen dezer naamverwisselingen bij Moreland: Peter Floris, Introduction $\S 6$.

3) Vgl. over deze eerste anwezigheid van de Globe in Patani: Anderson, 
Toen het schip den $25^{\text {en }}$ Augustus voor Ajudhja kwam, trof het daar bijster slechte omstandigheden aan. Het land was vol oorlogsdreiging, en zoo viel er aan het rustig handeldrijven vooreerst niet te denken. Wel ondervond men veel welwillendheid aan 't hof van Siam; de Engelschen kregen de beschikking over een voor den handel geschikt steenen huis, vlak bij de loge der Nederlanders gelegen, en konden daar alvast wachten op betere omstandigheden. Het doel echter, een zoodanig cargasoen in Siam te verkrijgen, dat men daarmee wederom aan de Koromandelkust winstgevenden handel kon drijven, werd gemist. Tot overmaat van ramp bleek de nieuwe kapitein van de Globe, Essington, zijn personeel niet te beheerschen, zoodat het tot ernstige muiterij kwam, waarbij de stuurman John Johnson de leiding nam. Deze twist culmineerde in een handgemeen tusschen Essington en Johnson, nadat de laatste, volgens Floris' verhaal, ,so drunke that hee coulde not well stande", den kapitein op alle mogelijke invectieven had onthaald, ,calling him rogue, rascall, dogge, and other suchelyke vile woords". Het eind was de afzetting van Essington, die in zijn post bij provisie werd vervangen door John Skinner. Dergelijke weinig stichtelijke gebeurtenissen waren natuurlijk niet geschikt, het aanzien der nieuwgekomenen bij de inlanders te vergrooten. Toen, den $13^{\text {en }}$ November 1612, de Globe weer naar Patani terugvoer, Lucas Antheunis als factor in Ajudhja achtergelaten hebbende, kon men dan ook alleen het feit, dat er een nieuwe factorij voor de East Indian Company gesticht was, als winst van dit bezoek beschouwen. 21 November was het schip weer voor Patani; de opvarenden konden daar al even min veel goeds over den handel vernemen. Met den verkoop van de kleedjes was het slecht gegaan ${ }^{1}$ ).

Zoo had men geen voldoende cargasoen om er mee naar Koromandel te gaan, gelijk de bedoeling was geweest. Ook andere redenen pleitten trouwens tegen dit plan. Het was reeds eenigszins ver in ' $t$ seizoen om dezen tocht te ondernemen ${ }^{2}$ ), en verder vreesde Peter

p. 48, 50; Reisverhaal van Nathaniel Marten bij Purchas III, p. 316; Moreland, p. 32 v.; Letters Received II, $N^{\circ} 167$. (Niet onvermakelijk is het uittreksel hieruit in Cal. State Papers 1513-1616 No 771, waarin gezegd wordt, dat de Engelschen naar Siam gingen in een ,goudon", die ze gebouwd hadden. De "goudon” of "godown" is het pakhuis.); de extract-brief van Van den Broecke, bedoeld op p. 23, noot 2 .

1) Zie over den tijd van het verblijf der Globe in Siam in 1612: Anderson, p. 48, 50 v.; W. A. R. Wood: A history of Siam, London 1926, p. 162; Nathaniel Marten in Purchas III, p. 318; Moreland, p. XXV, XXIX, 41 v., 45, 49, 59, 61 ; Lett. Rec. II, No 167.

2) Vgl. p. 2. 
Floris voor de orde op het schip. Wanneer hij zelf aan de Koromandelkust veel aan land zou moeten vertoeven, zou onder 't scheepsvolk't hek van den dam zijn, ,drincking theymselves druncke, fighting, knocking, dycing and suche lyke good poyntes used among theym"; met de tucht op de Globe ging het namelijk nog lang niet naar wensch. Aldus werd op 22 November 1612, den dag na de aankomst dus, geresolveerd, dat het schip in Patani zou overwinteren. Tot in Maart 1613 wachtte men alzoo, hopende, de komst der Chineesche jonken nog mee te maken. Deze kwamen echter later, dan de Engelschen gehoopt hadden; tenslotte scheen het daarom wenschelijk, weer naar Siam te vertrekken, waar misschien meer winst viel te behalen. Inderdaad had Hendrik Janssen van Houtman bericht in dien geest ontvangen ${ }^{1}$ ): Lucas Antheunis, aldus luidde deze tijding, had meer dan de helft van zijn goederen verkocht. Zoo vertrok 28 Maart 1613 de Globe ten tweeden male naar Siam, ook al in de hoop, daar vrij wat Chineesche waren te kunnen koopen, en dan na terugkomst toch nog met een belangrijk cargasoen den tocht naar Koromandel te ondernemen ${ }^{2}$ ).

De Globe bereikte Siam op 3 April of kort daarvoor; de datum van 't anvaarden der terugreis naar Patani is ons niet bekend; het zal wel in September geweest zijn; wel weten we, dat 't schip daar op 3 October 1613 weer aankwam, na de loge te Ajudhja onder leiding van Lucas Antheunis te hebben achtergelaten. Wat den handel betreft, had de Globe inderdaad een beteren toestand aangetroffen dan in 1612. Wel hadden de bezwaren niet ontbroken; zoo had de koning van Siam een partij kleedjes, welke hij van de Engelschen in principe had gekocht en twee maanden in zijn huis had gehouden, tenslotte weer aan de Engelschen doen teruggeven, daar zijn factor een zoo lagen prijs ervoor had willen betalen, dat Lucas Antheunis er geen voordeel in zag, ze tegen dit bod te laten. Maar toch kon de Globe naar Patani vertrekken met een lading van 13000 realen van achten in goud, zilver en koopmanschappen. Hieronder zullen ook wel Chineesche artikelen geweest zijn: Houtman schrijft althans op 24 April 1613 aan Hendrik Janssen, dat volgens zijn meening de Engelschen in Siam wel een partij grove porseleinen tot goeden

1) Ontvangen 4 Febr. 1613.

2) Vgl. over het tweede verblijf van de Globe in Patani: Anderson, p. 51 v.; Moreland, p. 59 v.; Cal. St. P. 1513-1616, No 621; Lett. Rec. II, No 167; Copiebrief van Marten Houtman aan Hendrik Janssen te Patani, Ajudhja, 24 April 1613. 
prijs zullen bekomen. Graag had Lucas Antheunis met de Globe nog meer naar Patani verzonden, maar dit was hem onmogelijk geweest. Trouwens ook zooals het was, zal het cargasoen in Patani, waar men er met spanning naar had uitgezien, zeer welkom geweest zijn. Men had er zoodanig gebrek aan middelen gehad, dat Peter Floris ertoe had moeten overgaan, geld te leenen van de koningin, iets, wat we ook bij de Hollanders kennen. 3000 realen had hij van haar opgenomen ${ }^{1}$ ).

Nauwelijks was de Globe - 3 October - van haar tweeden tocht naar Siam in Patani aangekomen, of onder de opvarenden barstte weer hoogloopende twist uit. $\mathrm{Nu}$ was kapitein Essington de dwarsdrijver. Toen deze van Peter Floris had vernomen, dat de naaste bestemming van het schip de kust van Koromandel was, makte hij hiertegen bezwaar: lekkage en onwil bij het scheepsvolk deden het hem wenschelijk voorkomen, direct naar Engeland terug te gaan. Peter Floris wilde zich echter niet van zijn voornemen laten afbrengen; hij vertelt ons, hoe Essington toen de bemanning tegen hem trachtte op te zetten, en "playde many prankes, which all did tende to the hurte and hinderance of the voyage". Tevergeefs echter: tenslotte kreeg Peter Floris zijn zin. Er werd nu besloten, dat als hoofd van de factorij Robert Littlewood zou worden achtergelaten, en, waar diens gezondheid te wenschen overliet ${ }^{2}$ ), zou een neef van Floris, William Ebert, hem ter zijde staan. Zekere Ralph Cooper werd aan hen toegevoegd. Eindelijk vertrok dan de Globe, en nu voorgoed, uit Patani op 1 November, met een goede partij Chineesche waren en andere artikelen aan boord, naar Koromandel ${ }^{3}$ ).

Dat de expeditie van de Globe bij de Hollanders in Patani eenige beroering had gebracht, valt te begrijpen. Het is waar: naar 't uiterlijke liet de verhouding tot de nieuwgekomenen niets te wenschen over. Hendrik Janssen en Peter Floris waren, zegt de laatste, ,greate friendes" ${ }^{4}$ ), en ook Lucas Antheunis schijnt in Siam op zeer vriend-

1) Zie over den tweeden tocht van de Globe naar Siam: Anderson, p. 55; Moreland, p. 73 v., 91; Lett. Rec. II, $\mathrm{N}^{\circ}$ 167; Copiebrief van Marten Houtman aan Hendrik Janssen te Patani, Ajudhja, $18 \mathrm{Mt}$. 1613; idem aan denzelfde, Ajudhja, 24 April 1613.

2) „A man that hath shortened his lyfe very much with drincking”, schrijft Floris in 1615 na Littlewood's dood.

3) Vgl. over het laatste bezoek van de Globe aan Patani: Anderson, p. 55 v.; Moreland, p. XXIV, 91 v., 96 v., 142; Lett. Rec. II, N 167; Tiele Eur. 5, I, p. 268; Hendrik Janssen aan Jacop die Schot te Bantam, Patani, 12 Oct. 1613; Abraham van den Broecke aan beww., Patani, 12 Oct. 1613.

4) Moreland, p. 69. 
schappelijken voet te hebben omgegaan met den Hollandschen factorijhouder Marten Houtman ${ }^{1}$ ). Samen namen de Engelschen en de Nederlanders deel aan een buitenfeest, dat door de koningin van Patani werd gegeven tijdens het tweede verblijf van de Globe aldaar, waarbij, nadat al de edelen voor de vorstin gedanst hadden, ook Engelschen en Hollanders hiertoe genoopt werden, ,wherewith the olde Queene was muche rejoyced" ${ }^{2}$ ). Een paar malen verscheen verder, toen de Globe op haar tweeden tocht naar Siam was, Floris, eerst met Hendrik Janssen, later met dezen en Abraham van den Broecke samen bij den koning van Pahang, die zich toen in Patani bevond ${ }^{3}$ ). Teekenend is verder ook, dat de Engelschen des avonds vóór hun definitieve vertrek naar de Koromandelkust een afscheidsmaaltijd met de Hollanders hielden ${ }^{4}$ ).

Maar deze vriendschap had veel gedwongens. Het was, zooals Coteels op 13 Maart 1612 aan Hendrik Janssen schreef: wel hadden de Nederlanders in Patani de oudste rechten, doch de Engelschen, als onderdanen van een Christenkoning, waar ons land geen vijandschap tegen koesterde, moesten worden ontzien ${ }^{5}$ ). Maar dat ze den onzen hinderlijk waren, is zeker. Hendrik Janssen klaagt, dat de lijnwaden laag in prijs zijn vooral door de Engelschen, „die den clad daer inne brengen" ${ }^{6}$ ); ook Van den Broecke uit zich over de schade, die Peter Floris in Patani en Lucas Antheunis in Siam den onzen aanbrengen ${ }^{7}$ ). En Coen schrijft over de nieuwe concurrenten aan de bewindhebbers te Amsterdam, dat Hendrik Janssen grooteren voorkoop van zijde en andere waren gedaan zou hebben, als niet de Engelschen het goed voor een prijs naar hun eigen zin gekocht hadden; voor porselein hadden zij in Patani een spotprijs betaald ${ }^{8}$ ). Een geluk mag het bij dit alles nog genoemd worden, dat ze er niet in slaagden, zich naast ons in het toen veelbelovende Sangora te vestigen ${ }^{9}$ ).

We mogen dan ook aannemen, dat Adam Denton de stemming volkomen juist aanvoelde, toen hij, in tegenstelling met de eervolle

1) Moreland, p. LXI.

2) Moreland, p. 62 v.

3) Moreland, p. 82, 85 .

4) Moreland, p. 98 .

5) Mateo Coteels aan Hendrik Janssen te Patani, 20 Mt. 1613.

6) Hendrik Janssen aan Jacop die Schot te Bantam, Patani, 12 Oct. 1613.

7) De extract-brief van Van den Broecke, bedoeld op p. 23 noot 2.

8) J. P. Coen aan beww. te Amst., Bantam, 1 Jan. 1614 (Col. Coen I, p. 1 v.).

9) Zie p. 69 . 
ontvangst, aan zijn landgenooten bij hun komst van wege de koningin ten deel gevallen, eenigen afkeer bij de Hollanders opmerkte ${ }^{\mathbf{1}}$ ). En eenig leedvermaak is bij de laatsten niet te miskennen, als ze meenen op te merken, dat hun concurrenten niet zooveel winst weten te behalen, als ze zich voorgesteld hadden. 12 October 1613, tijdens 't laatste verblijf van de Globe in Patani dus, schrijft Hendrik Janssen (die n.b. in denzelfden brief over de Engelsche concurrentie klaagt!), dat het crediet der Engelschen in Patani uit is, ,ende roepen nu zoo luide van haer winninghe niet alse wel in 't eerste deden" 2 ). Overeenkomstig uit zich op den zelfden datum Van den Broecke: Peter Floris en Lucas Antheunis ,beginnen haer ooren te laten hangen”, daar hun winst veel kleiner wordt, dan ze zich hadden voorgesteld ${ }^{3}$ ). We kunnen bij deze uitingen niet ontkomen aan den indruk, dat de wensch de vader van de gedaichte is.

Hoe het ook zij, we mogen, wat Patani betreft, gerust meegaan met het oordeel van Moreland, wanneer deze over de reis van de Globe zegt: ,,it contributed materially to the growth of that ill feeling between Dutch and English which culminated in open warfare between the two Companies" ${ }^{4}$ ).

In 1614 zagen de Hollanders in Patani wederom Engelsche schepen verschijnen, namelijk de Darling en de James, welke gezamenlijk den $9^{\text {en }}$ Juli ter reede verschenen. Het eerste schip, waarop Robert Larkyn kapitein was, telde niet tot de meest zeewaardige van de East Indian Company. ,"The Darling complaineth sore”, zoo had Larkyn reeds uit Soekadana geschreven, ,but I hope to God she will carry us well to Puttani" 5). Op de James bevond zich als kapitein Edmond Marlowe, die zich door zijn dronkenschap en heerschzucht op dezen tocht gehaat maakte. Bij aankomst in Patani trof men, zooals Adam Denton ${ }^{6}$ ) schrijft, ,those three persons left by us in the Globe all in health" 7). De bedoeling der nieuwgekomen Engelschen was nu vooral, door verkoop van een lading van ongeveer 250 fardeelen ${ }^{8}$ )

1) Lett. Rec. II, $\mathrm{N}^{\circ} 167$.

2) Hendrik Janssen aan Jacop die Schot te Bantam, Patani, 12 Oct. 1613.

3) Abraham van den Broecke aan beww., Patani, 12 Oct. 1613.

4) Moreland, p. XXXV.

5) I.tt. Rec. II, $\mathrm{N}^{\circ} 142(3)$.

6) Denton kwam op de James in Patani.

7) Lett. Rec. II, $N^{0} 167$. Zie behalve de twee reeds genoemde brieven ook nog over de komst van Darling en James: Anderson, p. 56 v.; Lett. Rec. I, p. XXXVI, II, p. XXIV en $\mathrm{N}^{\circ} 142(4)$; Hendrik Janssen aan beww. te Amst., Patani, 20 Oct. 1614.

8) Pakken; Port. fardo. 
kleedjes, afkomstig van Suratte en de Koromandelkust, een goede lading Lankin-zijde ${ }^{1}$ ) op te koopen. Hun handel ging echter aanvankelijk niet voorspoedig: de „pinnace” van de Hollanders, zoo hooren $w^{2}$ ), was hun te gauw af geweest, en had, een maand vóór de Engelsche schepen gekomen zijnde, alle beschikbare zijde op kunnen koopen. Met deze pinas moet wel het jacht Jacatra bedoeld zijn, dat echter reeds vroeger voor Patani was verschenen, namelijk op $17 \mathrm{Mei}$ $1614^{3}$ ). En de door de Engelschen meegebrachte kleeden bleken in Patani vrijwel onverkoopbaar te zijn: vrees voor Atjehsche aanvallen had een stremmenden invloed op den handel, terwijl ook onderhandelingen met de orangkaja's een stug verloop hadden wegens oneenigheid over de aan dezen te verleenen geschenken.

Maar misschien zou, zoo dacht men, Siam betere kansen bieden. Daarom werden uit de James maar weinig goederen in Patani aan land gebracht, het grootste deel ervan echter ingescheept in de Darling, die voor de reis naar Siam bestemd was, zoodat daar \pm 200 fardeelen kleeden konden worden aangebracht. Kapitein Marlowe werkte mede om de Darling tot den voorgenomen tocht in staat te stellen, door er b.v. timmerlieden uit de James aan mee te geven, wat stellig voor het wrakke schip geen overbodige luxe was ${ }^{4}$ ).

Doch ook de James zelf eischte herstel; het moest op zij worden gelegd, om aan den onderkant de noodige reparaties te kunnen ondergaan; de Engelschen zonden daarom zekeren Davis op kondschap naar Sangora, waarover zij als scheepsherstelplaats van de Hollanders hadden kunnen hooren. Davis verklaarde Sangora zeer geschikt voor de voorgenomen reparatie, welke dan ook aldaar werd verricht. Konden de Hollanders dit met gelijkmoedigheid aanzien, anders stond het met Marlowe's pogingen om in Sangora een afzetgebied voor zijn particulieren kleedenvoorraad te vinden en er verder zijn 3000 realen van achten aan contanten te besteden. Ja zelfs poogde hij er een huis voor de Engelschen te krijgen en de zelfde rechten, die de Nederlanders genoten. Al deze dingen mislukten hem echter, daar men zich in Sangora hield aan de afspraken, met de Nederlanders gemaakt.

1) Vg1. p. 118.

2) Lett. Rec. II, No 226.

3) Zie p. 81 .

4) Zie over den handel van Darling en James: Anderson, p. 58; Moreland, p. 141; Lett. Rec. II, $\mathrm{N}^{\circ} 142$ (4), $\mathrm{N}^{\circ} 142(6), \mathrm{N}^{\circ} 154, \mathrm{~N}^{\circ} 158, \mathrm{~N}^{\circ} 162, \mathrm{~N}^{\circ} 167, \mathrm{~N}^{\circ} 226$, $\mathrm{N}^{\circ} 244, \mathrm{IV}, \mathrm{N}^{\circ} 339$; Hendrik Janssen aan beww. te Amst., Patani, 20 Oct. 1614. 
$\mathrm{Na}$ het herstel in Sangora vertrok de James in 't laatst van $1614^{1}$ ) naar Bantam, voor den verkoop van de goederen Adam Denton in Patani achterlatend. $\mathrm{Na}$ de aanvankelijke teleurstelling schijnt de handel aldaar beter te zijn gegaan; we lezen althans, dat het schip in Bantam aankwam ,bringing a reasonable cargason" ${ }^{2}$ ).

Denton's oordeel over Patani is niet gunstig: hij vindt de plaats niet de moeite waard om aan te houden, al zou er met den kleedjesverkoop ook eenig voordeel gedaan kunnen worden, gelijk ook met den inkoop van zijde voor Engeland en Japan, en van goederen voor de Molukken ${ }^{3}$ ).

Vóór de James was ook reeds het schip de Darling uit Patani vertrokken, en wel op zijn voorgenomen tocht naar Siam. Hoewel ook de Darling eenigszins gerepareerd was in Sangora, zal de stemming der opvarenden toch allesbehalve gerust geweest zijn; vooral werd er ernstig aan getwijfeld, of een meer grondige reparatie aan de kust van Koromandel, uit te voeren na dezen tocht, nog mogelijk zou zijn. Tegenover de Hollanders hield men zich echter groot: behalve Siam, zoo vernamen dezen, zou de Darling zelfs nog Cambodja aandoen, om daar, zoo men een geschikte plaats aantrof, mede een kantoor te stichten. „Zij hebben veel wints in 't hooft, doch sonder fondament", geeft Hendrik Janssen hun na, als 't wrakke schip op 9 Augustus naar 't Noorden vertrokken is. En ze jagen, zoo vervolgt hij, meer hun particuliere profijten na dan het voordeel van hun meesters.

Inderdaad vond de Darling een klaaglijk einde. Waarschijnlijk omstreeks 10Mei 1615 ging het schip uit Ajudhja naar Patani terug, waar het in zoo desolaten 'toestand aankwam, dat men er geen verdere reizen mee durfde te wagen; ook kon het in Sangora niet afdoende hersteld worden. Tot overmaat van ramp heerschte er nog tweedracht onder de bemanning. Zoo werd clan in Juni of Juli door Robert Larkyn en den raad van de factorij van Patani besloten, het schip, als onreparabel, op te leggen, waarna het gesloopt werd. Het kapitaal eruit bleef in Patani achter onder de hoede van Larkyn, terwijl de

1) Volgens Anderson (p. 58 v.) in Oct. 1614. Dit is oude stij1, zoodat het volgens onze tijdrekening ook in November kan geweest zijn.

2) Moreland, p. 140.

3) Zie over het vertrek van de James: Anderson, p. 58 v.; Moreland, p. 140, 142; Lett. Rec. II, XXIV, No 142 (4), $\mathrm{N}^{\circ} 159, \mathrm{~N}^{\circ} 159 \mathrm{~A}, \mathrm{~N}^{\circ} 162, \mathrm{~N}^{\circ} 167$, III, p. 179, noot 1, IV, $N^{\circ} 339$; Hendrik Janssen aan beww. te Amst., Patani, 20 Oct. 1614. 
rest van de bemanning en het geschut naar Bantam werden getransporteerd ${ }^{1}$ ).

In 't laatst van 1614 ziet Coen het gevaar van de Engelsche concurrentie in Patani zeer ernstig in. Hij is dan nog optimistisch gestemd over de handelsmogelijkheden in Patani en Sangora, mits deze kantoren goed met kapitaal voorzien worden ${ }^{2}$ ), ,derhalven”, schrijft hij aan bewindhebbers, ,soude verwondert syn, dat U.E. d' Engelsen dese plaetse cedeerde" ${ }^{3}$ ). Dat we ons naast dezen slechts met moeite zouden kunnen handhaven, scheen toen een feit: Patani werd door de Engelschen als een der voornaamste plaatsen van hun kolonisatie beschouwd. Het was de bedoeling van de Company, dat er vier hoofdpunten zouden zijn om beter toezicht op de andere factorijen te kunnen houden, ieder met een opperhoofd, dat agent, directeur, consul of ook anders zou kunnen genoemd worden, respectievelijk zetelend in Suratte, aan de Koromandelkust, in Bantam en in Patani ${ }^{4}$ ). De bedoeling is dan geweest, dat het hoofd in Patani het toezicht zou hebben ook over Siam, Cambodja, Cochinchina, Japan, Borneo ,and the places thereabouts" ${ }^{5}$ ).

En de Engelsche vaart op Patani stond niet stil; ook in 1615 werden de Hollanders wederom verontrust door 't bezoek van twee schepen, de Osiander ${ }^{6}$ ) en de Solomon. Het eerste schip had Japan als hoofdbestemming, maar moest voordien de factorijen van Soekadana en Patani bezoeken en van 't noodige voorzien ${ }^{7}$ ). De tijd van aankomst in Patani is niet bekend; wel weten we, dat het schip op 15 Juli 1615 daarvandaan voer naar Hirado $^{8}$ ).

Ook de tijd van aankomst van de Solomon is onbekend. In ieder

1) Volgens Lett. Rec. III, No 294, met een Engelsche jonk, welke 30 Sept. te Bantam aankwam. In verband hiermee lijkt me onjuist, wat in Lett. Rec. I, XXXVI, wordt gezegd, dat het volk op een Nederlandsch schip naar Bantam gevoerd werd. Zie over het einde van de Darling, behalve de hier genoemde plaatsen: Anderson, p. 58, 61; The second voyage of captain Walter Peyton into the East-Indies, in Purchas, dl. IV, p. 304; The journal of John Jourdain, 1608-1617, ed. William Foster, Hakluyt Society, 1905, p. 239, noot 2; Lett. Rec. II, $\mathrm{N}^{\circ} 159, \mathrm{~N}^{\circ} 162, \mathrm{~N}^{\circ} 167$, III, $\mathrm{N}^{\circ}$ 324; Hendrik Janssen aan beww. te Amst., Patani, 20 Oct. 1614; idem aan dezelfden, Patani, 25 Oct. 1616.

2) Zie p. 91.

3) J. P. Coen aan beww., Bantam, 10 Nov. 1614 (Col. Coen I, p. 52 v.).

4) Cal. St. Papers 1513-1616, No 740.

5) Lett. Rec. IV, p. XV, noot 1.

6) Ook Hosiander genoemd. Vgl. over den onzekeren oorsprong van dezen naam Moreland, p. 140, noot 1.

7) Lett. Rec. III, $\mathrm{N}^{\circ} 324$.

8) Lett. Rec. IV, $\mathrm{N}^{\circ} 339$. 
geval moet dit schip begin September al in Patani geweest zijn. De verdere bestemming was de Koromandelkust. Daarheen is het dan ook eind October of begin November vertrokken, toen het, naast de lading, uit Bantam afkomstig, in Patani nog eenig fijn en grof porselein, alsmede 15 à 18 picol benzoë had ingenomen. Met het schip voer ook Lucas Antheunis, dien we als factorijhouder in Siam hebben leeren kennen, uit Patani mee naar Koromandel $\left.{ }^{1}\right)^{2}$ ).

Hoe fel in dezen tijd reeds de Engelsche concurrentie tegen ons was, daarover weet Hendrik Janssen een merkwaardig voorbeeld mee te deelen. Toen de Engelschen hadden vernomen, dat er geen Chineesche jonk in Patani was te verwachten, één daarentegen in Sangora, rustten ze een bark "ofte balou" uit, bemand met een tiental musketiers ,ende bassen" ${ }^{3}$ ), den Nederlanders wijs makende, dat ze naar Siam wilden varen. Janssen kreeg echter achterdocht; een nader onderzoek bracht hem de bewijzen, dat de bark was uitgevaren om voor Sangora te wachten op de komst van de genoemde jonk, opdat zoo alle zijde, die daarin mocht zijn, tot een door de Engelschen zelf te bepalen lagen prijs zou opgekocht worden, en de Nederlanders niets zouden krijgen. Onmiddellijk bemande Janssen eveneens een scheepje ${ }^{4}$ ), dat aan de Hollanders behoorde, voer uit, en vond inderdaad dicht bij „Poelo Tijckos” ${ }^{5}$ ) „,dese visschers segge Syamsvaerders" voor anker liggen, ,die dadelijcken met beschaemtheyt haer schelmerije hebben geopenbaert, ende naer haer onbehoirlijcke proce-

1) Vgl. over het bezoek van de Solomon: Anderson, p. 62 v.; Lett. Rec. III, p. XXIV, $\mathrm{N}^{\circ} 292, \mathrm{IV}, \mathrm{N}^{\circ} 339, \mathrm{~N}^{\circ} 341, \mathrm{~N}^{\circ} 348, \mathrm{~N}^{\circ} 383, \mathrm{~N}^{\circ} 384$, appendix II ; Copiebrief van Hendrik Janssen aan 't kantoor te Bantam, Patani, 15 Nov. 1615.

2) Met de Solomon vertrok niet alleen Lucas Antheunis naar Koromandel, maar ook 't hoofd van het kantoor in Patani, Adam Denton (Lett. Rec. IV, $\mathrm{N}^{\circ} 348$ en $\mathrm{N}^{\circ} 384$ ). Robert Larkyn bleef volgens een besluit in Patani van 19 Oct. 1615 als factorijhouder aldaar achter, met John Browne als helper (Anderson, p. 62 v.; Lett. Rec. IV, appendix II). Larkyn is op 22 Mei 1616 in Patani overleden, en $24 \mathrm{Juni}$ daarna treffen we John Browne als hoofd der factorij an (The First Letter Book of the East India Company, ed. G. Birdwood and W. Foster, London 1893, p. 326, noot 3; Lett. Rec. IV, $\mathrm{N}^{\circ} 414$, $\mathrm{V}, \mathrm{N}^{\circ}$ 501). Omstreeks 't midden van 1618 wordt Browne als overleden gemeld (Anderson, p .70). Hij is dus waarschijnlijk de koopman van de loge, welke volgens Druyff (Copiebrief van Gerrit Frederiksz. Druyff aan beww., Patani, 4 Oct. 1618) in Juni 1618 door slaven der Portugeezen werd vermoord. De opvolger, die in Patani achterbleef, moet dan Edward Gilman geweest zijn, waarover Druyff zich ongunstig uitlaat (in genoemden brief; zie verder Anderson, p. 70).

3) Bas: zie p. 194, noot 5 .

4) Een bantin.

5) Zie p. 171. 
duijren syn aengewesen ${ }^{1}$ ), bennen wederomme naer Patanij soo wijs als se gecomen waeren gekeert". Geen wonder, dat onder deze omstandigheden de zijdeprijs opliep, tot nadeel van onzen handel. Ook het verkoopen van ivoor was in Patani moeilijker geworden door het contante geld, waarover de Engelschen bij het doen van hun inkoopen beschikten. Daar Janssen verder vermoedde, dat de Engelschen een sorteering kleedjes zouden doen maken, die in Siam in trek waren, zond hij naar Bantam een monster daarvan, opdat men er zoo spoedig mogelijk van zou zenden, „om haer daermede in den wech te wesen, ofte ten minsten haer de merckt te bederven" ${ }^{2}$ ). Coen schrijft daarop aan Hendrik Janssen, de gezonden monsters zoo spoedig mogelijk naar de kust van Koromandel te zullen zenden ${ }^{3}$ ). De krasse concurrentie der Engelschen, aldus Coen's gedachtengang in een brief aan bewindhebbers, beperkt zich niet tot een enkel kantoor, ook in Jacatra, in Jambi, in Siam en Japan berokkenen ze ons moeilijkheden, ,in somma daer en is geen plaets in Indien, off sy zyn ons aldaer vervolgende ende contraminerende" ${ }^{4}$ ).

Wat Patani betreft, had men zich echter al te bezorgd gemaakt voor de toekomst: in de jaren 1616, 1617 en 1618 is duidelijk een dalende lijn bij de Engelschen te onderkennen. Het aantal schepen, dat toen deze plaats bezocht, bedraagt maar twee, waarvan het eene nog in 't laatst van 1615 was gekomen. Dit was de Advice, die, op 13 December 1615, na een mislukte poging, Japan te bereiken, voor Patani ankerde, en vandaar op 6 Maart van het volgende jaar naar Bantam vertrok ${ }^{5}$ ). Verder treffen we in 1616 en ook in 't geheele jaar 1617 geen schip aan. Tot dan eindelijk in de eerste helft van 1618, gelijk Hollandsche bronnen ons leeren, de James Patani komt bezoeken ${ }^{8}$ ), om dit kantoor en dat van Siam weer den noodigen steun te verleenen. Toen echter de opperkoopman van het schip aan land was, kwam het tot een heftigen twist met de Portugeezen, over

1) Versta : nadat zij op het onbehoorlijke van hun handelwijze waren gewezen.

2) Copiebrief van Hendrik Janssen aan 't kantoor te Bantam, Patani, 15 Nov. 1615.

3) Copiebrief van J. P. Coen aan Hendrik Janssen te Patani, Bantam, $14 \mathrm{Mei}$ 1616 (Col. Coen II, p. 98 v.).

4) J. P. Coen aan beww. kamer Amst., Bantam, 22 Oct. 1615 (Col. Coen I, p. 114 v.).

5) Zie Lett. Rec. III, $\mathrm{N}^{\circ} 288, \mathrm{~N}^{\circ} 341$, appendix $\mathrm{N}^{\circ}$ II.

6) Door de Engelschen ook de "little James” genoemd. Waar in een schrijven van Aug. Spaldinge d.d. 19 Dec. 1619 sprake is van de „lesser James”, lijkt me twijfel gerechtvaardigd, of de "little James" hetzelfde schip is als de James, die in 1614 Patani bezocht. 
zeker nadeel, den Engelschen in „Androgery" ${ }^{1}$ ) aangedaan. Genoemde opperkoopman, die deze beleediging ,met een droncken hooft ende met een hastige Engelse furie wreecken" wilde, werd met den koopman van de $\operatorname{loge}{ }^{2}$ ) door een tienvoudige overmacht van slaven der Portugeezen in Juni op straat vermoord, zoodat de Engelsche loge in desolaten toestand achterbleef; het schip de James vertrok weder ${ }^{3}$ ), zonder dat deze misdaad was gewroken ${ }^{4}$ ).

De handel had in deze jaren alles te wenschen over gelaten; de groote lasten en andere voor de Engelschen onaangename gebruiken hadden het hunne daartoe bijgedragen. „I marvel”, zoo schrijft Cocks in 't eind van 1616 uit Japan aan John Browne in Patani, ,your factory is so bare as you advise me" ${ }^{5}$ ). En ongeveer een jaar later verklaart William Eaton in Firando, een brief van Browne te hebben ontvangen, die wel een zeer treurig beeld van den toestand gaf : men beschikte in Patani zelfs niet meer over zooveel geld of goederen, dat men er de noodige levensmiddelen voor kon koopen; waren er niet 1000 realen uit Siam gezonden, dan zou het er treurig voor de Engelschen hebben uitgezien ${ }^{6}$ ). Een brief van Hendrik Janssen van October 1617 bevestigt dit beeld ${ }^{7}$ ). En nog weer een jaar later, 4 October 1618, schrijft Gerrit Frederiksz. Druyff, hoe de Engelschen in hun berooidheid al jaren lang ,van 't hoopgen affgeteert hebben" ${ }^{8}$ ).

Geen wonder, dat deze omstandigheden de Engelschen tot moedeloosheid begonnen te stemmen. Reeds in Januari 1618 is het dan ook duidelijk, dat men te Bantam Patani al als een verloren post begon te beschouwen ${ }^{9}$ ). Wat kon voor de Nederlanders aangenamer zijn ?

1) Zal wel bet.: Indragiri.

2) Dit zal John Browne moeten zijn, vgl. p. 205, noot 2.

3) Naar we uit een extractbrief van John Jourdain aan Mr. Ufflett (Bantam, 11 Dec. 1618) mogen opmaken, in gezelschap van de $Z$ warte Leeuw en de Hollandia (vgl. p. 84).

4) Vgl. over de James: Cal. St. P. 1617-'21 No 775; Copiebrief van Gerrit Frederiksz. Druyff aan beww., Patani, 4 Oct. 1618; de extractbrief van Jourdain, genoemd in noot 3 ; J. P. Coen c.s. aan beww., in de Oude Zon, liggende voor Mandalique, omtrent 3 mijlen bij Oosten Japara, 14 Jan. 1619 (Col. Coen I, p. 416 v.); Gerrit Frederiksz. Druyff aan beww. kamer Amst., Patani, $26 \mathrm{Mt}$. 1619; Copiebrief van Cornelis van Nieuwenroode aan Jacques Specx in Firando, Ajudhja, 31 Mei 1619.

5) Lett. Rec. IV, $\mathrm{N}^{\circ} 414$.

6) Lett. Rec. VI, $\mathrm{N}^{\circ} 582$.

7) Copiebrief van Hendrik Janssen aan J. P. Coen te Bantam, Patani, 25 Oct. 1617.

8) Copiebrief van Gerrit Frederiksz. Druyff aan beww., Patani, 4 Oct. 1618.

9) Cal. St. P. 1617-'21, No 245. 
Hendrik Janssen ziet de kans, den gehaten tegenstander er geheel uit te werken! Maar.... ook voor de Nederlandsche Compagnie was Patani een twijfelpost geworden. We zagen, hoe hij ook, juist met 't oog op de Engelschen, Coen trachtte te bezweren, toch de kantoren in Patani en Sangora aan te houden, al was 't maar met geringe bezetting ${ }^{1}$ ). De inlanders gaven, aldus zijn overtuiging, aan de onzen de voorkeur ${ }^{2}$ ). In 1617 klaagt hij, dat gebrek aan goede sorteering kleedjes hem verhindert, van de slechte conjunctuur der Engelschen het juiste gebruik te maken ${ }^{3}$ ).

Wat Siam betreft, was de achteruitgaande lijn der Engelschen niet te constateeren: daar hebben dezen blijkbaar aan het hof zeer in de gunst gestaan. Coen schrijft dit toe aan "d' uutterlijcke pompe ende ilen roem, welcke d'Engelsen ommetom gewoon zijn te strooyen, daerdoor overal in 't eerste wonderlijck worden aengesien, maer ten lesten meer versmaet ende veracht blyven" ${ }^{4}$ ).

Voor 't uiterlijk was in Patani de verhouding tusschen beide concurreerende handelsvolken eerst nog goed. Toen b.v. Robert Larkyn 22 Mei 1616 aldaar was overleden ${ }^{5}$ ), werd de begrafenis, naar John Browne schrijft, geregeld ,in the best manner I could, with our poor household and with the Dutch" ${ }^{6}$ ). Maar een bedenkelijk teeken is het reeds, dat er een zekere stugheid optreedt bij het vervoeren van brieven met elkaars schepen. In 1615 reeds konden de Engelschen in Patani niet gedaan krijgen, dat met de Jacatra en de Enkhuizen ${ }^{7}$ ) een brief werd vervoerd naar Japan ,to advise us of the Osiander's coming. Only they said we had a small ship coming, but they knew not her name" ${ }^{8}$ ). En omgekeerd: Hendrik Janssen schrijft in hetzelfde jaar naar Bantam ${ }^{9}$ ), dat hij graag met de Solomon naar Koromandel geschreven zou hebben, ,dan wilden geen gesloten missiven, ofte die

1) Zie p. 92.

2) Hendrik Janssen aan beww. te Amst., Patani, 25 Oct. 1616.

3) Copiebrief van Hendrik Janssen aan J. P. Coen te Bantam, Patani, 25 Oct. 1617.

4) Copiebrief van J. P. Coen aan Hendrik Janssen te Patani, Bantam, 14 Mei 1616 (Col. Coein II, p. 98 v.). Zie verder over hun positie in Siam: Anderson, p. 70; Gerrit Frederiksz. Druyff aan beww. kamer Amst., Patani, 26 Mt. 1619.

5) Zie p. 205, noot 2 .

6) Lett. Rec. IV, No 405 .

7) Zie p. 81 v.

8) Aldus Richard Cocks te Firando aan president Jourdain te Bantam (Lett. Rec. III, No 322. Zie ook $\mathrm{N}^{\circ} 320$ ).

9) Copiebrief van Hendrik Janssen aan 't kantoor te Bantam, Patani, 15 Nov. 1615. 
mentie van eenighe coopmanschappen maecten, aenveerden". Men ziet: in beide gevallen weerzin tegen 't medewerken aan handelsvoordeel der ,geveinsde vrienden”!

De stijgende invloed van Coen werkte, het is bekend, de verscherping der verhoudingen in de hand. Als hij in December 1617 aan bewindhebbers schrijft over de groote insolentie, door de Engelschen alom tegen ons gepleegd ${ }^{1}$ ), dan noemt hij ook Patani. Hier zagen én Engelschen én Nederlanders hun voordeel tanen: wat wonder, dat we bij den bitteren strijd om 't bestaan bij Compagnie's dienaren steeds grimmiger toon aantreffen! De Engelschen zijn, aldus Hendrik Janssen, ,een deel groote opsnappers ende domminateurs" ${ }^{2}$ ). En volgens Druyff laten de Engelschen na de vermoording van hun koopman in $1618^{3}$ ) ,een hoveerdigen halwe narre" als koopman achter ${ }^{4}$ ), die het zoo aanlegt, dat al de mandarijnen en Maleiers „een walge daer van hebben”, terwijl zijn snorkend en pochend optreden den Hollanders de grootste moeilijkheden berokkent ${ }^{5}$ ). In Siam liet de verhouding al evenzeer te wenschen over. De Nederlanders, zoo schrijft vandaar op 7 Juni 1617 John Johnson naar Patani, trachten ,to hurt us by their lying, vigorous, scorpion tongues". "If we could hear but one true word proceed out of a Dutchman's mouth, I should think one among a thousand honest". „And for Holtman ${ }^{6}$ ), I never see a man more unhuman in my life" $\left.{ }^{7}\right)$. Men ziet: de stemming was tot een zoodanig kookpunt gestegen, dat een uitbarsting licht kon komen.

Niet alleen in Patani en Siam, overal, in Bantam, in de Molukken, bestond dezelfde spanning. In de wateren der Banda-eilanden werden vier Engelsche schepen door de Nederlanders in beslag genomen ${ }^{8}$ ). De Engelschen, niet gezind, zich door de ,beati possidentes" in een hoek te laten dringen, besloten tot een groote krachtsinspanning. De inschrijvingen op de nieuwe ,joint stock" voor een tijdvak van vier jaren hadden de East India Company daartoe den financieelen grondslag gegeven ${ }^{9}$ ). Openlijke strijd stond op uitbreken. En nu is het

1) J. P. Coen aan beww., Bantam, 18 Dec. 1617 (Col. Coen I, p. 290 v.).

2) Copiebrief van Hendrik Janssen aan J. P. Coen, Patani, 25 Oct. 1616.

3) Zie p. 206 v.

4) Hiermee zal Edward Gilman bedoeld zijn, zie p. 205 noot 2.

5) Copiebrief van Gerrit Frederiksz. Druyff aan beww., Patani, 4 Oct. 1618.

6) De meermalen genoemde Marten Houtman.

7) Lett. Rec. V, No 493.

8) Colenbrander: Kol. Gesch. II, p. 103 en 105.

9) Elias II, p. 33. 
merkwaardig, dat we bij den aanvang hiervan aantreffen : de factorij van Patani, en den pas afgetreden directeur aldaar: Hendrik Janssen.

We zagen reeds, hoe deze in 1618, na zijn laatste bestuursperiode, op het rijk geladen schip de Zwarte Leeuw naar het Zuiden vertrok $^{1}$ ). Opperkoopman op het schip was Cornelis Houbraecken, schipper Jacob Panckeras. Hoewel de lastgeving van Coen, per Klein Hollandia gezonden, luidde, dat het schip zich naar Jacatra moest begeven ${ }^{2}$ ), kwam de $Z$ warte Leeuw op 14 December in de buurt van Bantam aan, en niet in staat, de reede te bezeilen, verviel het aan de Westkust van 't dichtbij gelegen eiland Poeloe Pandjang. Daar zagen de opvarenden een Engelsche roeisloep op zich afkomen, waarin zich Adam Denton bleek te bevinden, die in Patani Hendrik Janssen had leeren kennen en daar op den meest vriendschappelijken voet met hem omgegaan had. Janssen had dan ook niet het geringste vermoeden, dat Denton met verraderlijke plannen kwam, in opdracht van Sir Thomas Dale, die zich als almiraal over vijftien Engelsche schepen in de buurt bevond. De Engelschman deed zich op de meest onschuldige wijze voor, ,wonder vertellende van de groote vriendschap, die tusschen haer ende ons was". Hij wist, hoewel eerst na eenig aandringen, ,,met een schoon praetgen” Janssen te overreden, het schip te verlaten, om met hem mee aan land, naar Bantam, te varen. Ook een der onderkooplieden van de $Z$ warte Leeuw, Jan Janssen Hoochlant, was hierbij van de partij. Maar in plaats van naar Bantam werden de Hollanders aan boord van het schip de Moone gebracht, waar ze „uijttermaten colorijck ende gepassioneert” werden toegesproken over wat den Engelschen in de Molukken was aangedaan. Daarna werden ze in denzelfden nacht te Bantam aan land gezet.

Erger was, wat met de Zwarte Leeuw gebeurde. In dezen nacht namelijk deed admiraal Dale vier van zijn schepen, de Moone, de Clove, de Sampson en de Globe, versterken met bemanning uit de andere, waarop zij vroeg in den morgen, 15 December, bij de Zwarte Leeuw kwamen liggen, ,dreygende alle d' onse op te hangen, soo haer niet overgaven". Het schip, van weinig kruit voorzien, en des te weerloozer door zijn groote lading, werd een gemakkelijke prooi van de Engelsche krijgslist. De koopman en de schipper, te laat ontwaakt zijnde om nog tijdig naar Jacatra te kunnen vertrekken, gaven dan ook geen gehoor aan het scheepsvolk, dat bereid zou geweest zijn,

1) Zie p. 95 .

2) Zie p. 84 . 
een ongelijken strijd te aanvaarden. Ze onderhandelden, en gaven het schip met zijn rijke lading aan den vijand over op accoord, dat al het volk met die zaken, welke als particulier eigendom waren te beschouwen, vrijelijk zou mogen gaan, waarheen het wilde. In strijd met de gedane belofte werd echter het scheepsvolk toch door de Engelschen gevangen gehouden, met uitzondering van elf man, die werden vrijgelaten, en tien, die wisten te ontkomen. Het aantal overblijvende gevangenen bedroeg 50 à 60 personen. Op 16 December werd de Zwarte Leeuw bij de rest van de Engelsche vloot gebracht $\left.{ }^{1}\right)^{2}$ ).

Veel genoegen hebben de Engelschen niet aan hun buit beleefd. Nadat ze ongeveer drie weken het schip in hun bezit hadden gehad, ging het, bij Jacatra liggende, op 17 Januari 1619 verloren door de onvoorzichtigheid van hun eigen volk, juist op den morgen van den zelfden dag, dat het plan bestond, het gewichtigste deel van de lading in Engelsche schepen over te brengen. „Some idle fellows”, zooals we vernemen, in beschonken toestand, trachtten zich te goed te doen aan de $\operatorname{arak}^{3}$ ), die zich op de Zwarte Leeuw bevond, en morsten hierbij een gedeelte, hetwelk ze, hoogst onvoorzichtig, in brand staken. Het vuur breidde zich toen uit tot het geheele schip, dat in vijf uren tijd met zijn kostbare lading tot op het water afbrandde. Als daders worden ons genoemd Owen Bodman, James Littill, Adam Douglas en zekere Portugees Domingo ${ }^{4}$ ).

1) $Z$ ie over het nemen van de $Z$ warte Leeuw: De Jonge: Opkomst IV, p. LXXXI; Tiele:.Eur. 5, II, p. 212; Relations and remembrances by John Hatch, bij Purchas IV, p. 539; The second voyage of Captaine Pring into the EastIndies, bij Purchas V, p. 10 v. ; Heeres: Hendrik Janssen, p. 120 v.; Anderson, p. 73; Cal. St. P. 1617-'21, N ${ }^{\circ} 601, N^{\circ} 734$; Copie-res. van president en raden, Jacatra, 16 Dec. 1618 (Col. Coen III, p. 474 v.); Copiebrief van J. P. Coen aan Reael te Amboina, Jacatra, 30 Dec. 1618; J. P. Coen c.s. aan beww., in de Oude Zon, liggende voor Mandalique, omtrent 3 mijlen bij Oosten Japara, 14 Jan. 1619 (Col. Coen I, p. 416 v.); Copie-sententie van G.-G. en Raden, fort Jacatra, 27 Juni 1619 (Col. Coen IV, p. 169 v.); Beschrijving, hoe de Engelschen in Dec. 1618 tegen ons een generalen oorlog aangevangen hebben en hoe de oorlog te Jacatra begonnen is; Copie-attestatie en verklaring door de opperhoofden van de $Z$ warte Leeuw, hoe het schip door de Engelschen genomen is.

2) In dezelfde lijn als het nemen van de $Z_{\text {warte }}$ Leeuw ligt het in beslag nemen van de jonk met rijst uit Sangora, waarvan sprake is geweest op p. 165.

3) „rackapée", zooals Sir Thomas Dale aan de East India Company schrijft. Rack $=$ arak. Rack-apee bevat het Maleische api = vuur. Zie Hobson-Jobson s.v. Arrack.

4) Vgl. over het verbranden van de $Z$ warte Leeuw : Heeres : Hendrik Janssen, p. 122 noot 1; Journal of John Jourdain, p. LXXIV en appendix F $4^{\mathrm{e}}$ gedeelte; Cal. St. P. 1617-'21 No 529, $\mathrm{N}^{\circ} 601, \mathrm{~N}^{\circ} 609, \mathrm{~N}^{\circ} 643$ en $\mathrm{N}^{\circ}$ 671; Copiebrief van de XVII aan Coen, Amsterdam, 9 Sept. 1620 (Col. Coen IV, p. 461 v.). 
Op het Nederlandsche bestuur in Indië maakte het nemen van de Zwarte Leeuw een overweldigenden indruk: het werd het sein tot den openlijken oorlog ${ }^{1}$ ). Het schijnt, dat onmiddellijk prauwen werden uitgezonden in allerlei richtingen, waar de Compagniesschepen lagen, om de opvarenden tegen soortgelijke aanslagen te waarschuwen ${ }^{2}$ ). In Jacatra, waar men eerst nauwelijks kon gelooven, dat de overval op een algemeene Engelsche politiek berustte, deed Coen een resolutie trekken, een expressen afgevaardigde te zenden aan Dale en zijn raad, voor Bantam liggende, teneinde opheldering te vragen, restitutie van de Zwarte Leeuw te eischen, en, zoo daar niet in werd toegestemd, de redenen van deze weigering te vernemen ${ }^{3}$ ).

Maar niet alleen tegen de Engelschen richtte zich de verontwaardiging der onzen; ook tegen Hendrik Janssen en de andere opvarenden, die het meest aansprakelijk konden gesteld worden voor het gebeurde, werd met strengheid opgetreden. Den $12^{\text {en }}$ Juni 1619 werden zij aan een verhoor onderworpen ${ }^{4}$ ), dat leidde tot het vonnis van 27 Juni daaraanvolgende: Hendrik Janssen, zoo werd hierin gezegd, had de gegeven order, om naar Jacatra te varen, moeten nakomen, en was ten onrechte naar Bantam geloopen; hoogst onverantwoordelijk was het verder, dat hij lichtvaardig het schip verlaten had, nog wel zonder met iemand der Nederlanders aan land overleg te hebben gepleegd; Cornelis Houbraecken en Jacob Panckeras hadden, daar zij toch hadden kunnen merken, dat er onraad dreigde, niet bij Poeloe Pandjang moeten blijven liggen, en hadden bovendien, op de ijdele ${ }^{5}$ ) dreigementen der Engelschen, zich op schandelijke wijze overgegeven. Op deze overwegingen werden alle drie veroordeeld tot verlies van hun gage van 1 November 1618 af: Hendrik Janssen tot 1 Februari $1619^{6}$ ), de beide anderen tot 10 Juni, toen ze op de schepen van Coen gekomen waren - diens zegepraal over Jacatra had toen reeds plaats gehad - Daarenboven werd Hendrik Janssen nog gestraft

1) Heeres : Hendrik Janssen, p. 122.

2) Extractbrief van John Jourdain aan Mr. Ufflett, Bantam, 11 Dec. 1618.

3) Tiele: Eur. 5, II, p. 212; Cal. St. P. 1617-'21 No 500; Copie-res. van pres. en raden, Jacatra, 16 Dec. 1618 (Col. Coen III, p. 474 v.).

4) Copie-attestatie en verklaring door de opperhoofden van de $Z$ warte Leeuw, hoe het door de Engelschen genomen is.

5) Men ziet, dat hier in de motiveering van het vonnis een inconsequentie schuilt. Als er inderdaad onraad was, dat een spoedige vlucht wenschelijk had gemaakt, kon de latere bedreiging (van 4 schepen nog wel!) moeilijk ijdel worden genoemd.

6) 7 Febr. daarop was hij uit Bantam als afgezant bij zijn landgenooten in het belegerde Jacatra gekomen (Heeres: Hendrik Janssen, p. 123). 
met verlies van drie, Houbraecken en Panckeras elk van twee maanden gage ${ }^{1}$ ).

Hoezeer was het aanzien gedaald van den man, die jaren lang zijn beste krachten aan de Compagnie had gegeven en als de centrale figuur van de geschiedenis onzer loge in Patani mag worden beschouwd! Spoedig daarna echter zou hij zich opmaken tot een expeditie, die bedoeld was, met geweld de geleden schade op de Engelschen te verhalen en hem persoonlijk de gelegenheid tot eerherstel te verschaffen.

Want Coen was niet gezind, voor Engelsch geweld te wijken. 15 Januari 1619 resolveerde hij, dat kooplieden en schippers van de Compagnie, waar ze ook maar konden, de Engelschen in hun macht moesten zien te krijgen, met zoo weinig bloedvergieten overigens als mogelijk was ${ }^{2}$ ). En toen hij had vernomen, dat de twee Engelsche schepen Sampson en Hound zouden zijn uitgevaren naar Jambi en Patani, zag hij de kans schoon, hier wraak te nemen voor wat met de $Z_{\text {warte }}$ Leeuw gebeurd was; en we weten, hoe hij daarbij aan Hendrik Janssen op diens verzoek het commando gaf over de schepen Engel, Bergerboot, Morgenster en Jager, om ,op de Engelse te passen". Eerst moest Janssen daarvoor Jambi aandoen, en, zoo de Engelsche schepen zich daar niet bevonden, verder naar Patani zeilen om ze daar, zoo mogelijk, te vermeesteren ${ }^{3}$ ).

Inderdaad waren de Sampson en de Hound op 4 Mei van Bantam ${ }^{4}$ ) naar 't Noorden vertrokken; dat er gewicht aan dezen tocht gehecht werd, blijkt uit het feit, dat niemand minder dan John Jourdain, President der Engelsche kantoren in Indië, aan 't həofd stond. Het doel was o.a. „to new establish both with men and means the almost decayed factories" van Jambi, Patani, Siam en Soekadana. Tot de opvarenden behoorde ook Adam Denton. De schepen kwamen 14 Mei voor Jambi aan, waar goederen en geld achtergelaten werden, waarop

1) Copie-sententie van G.-G. en Raden, fort Jacatra, 27 Juni 1619 (Col. Coen IV, p. 169 v.).

2) Copie-res., door Coen gezonden, in 't schip de Zon, tusschen Japara en Grissee, 15 Jan. 1619.

3) Vg1. p. 96. Vgl. ook: Copie-res. van G.-G. en Raden, fort Jacatra, 26 Juni 1619 (Col. Coen III, p. 519 v.) ; Copiebrief van J. P. Coen aan G. F. Druyff te Patani, Jacatra, 2 Juli 1619 (Col. Coen II, p. 571 v.); Copie-instructie van J. P. Coen aan Hendrik Janssen en raad van de schepen Engel, Bergerboot, Morgenster en Jager, Jacatra, 2 Juli 1619 (Col. Coen II, p. 575 v.).

4) Het mag niet onopgemerkt blijven, dat Anderson (p. 73) den onjuisten indruk geeft, alsof de Sampson en Hound van de Koromandelkust naar Jambi en Patani gevaren zijn. 
den $31^{\text {en }}$ van dezelfde maand de reis naar Patani aanvaard werd. 12 Juni kwam men er aan ${ }^{1}$ ).

Hier heerschten treurige toestanden. De factorij bevond zich in de grootste verwarring tengevolge van het karakterlooze en ijdele gedrag van Edward Gillman, die het bewind erover uitoefende $\left.{ }^{2}\right)^{3}$ ). Ook de Hollanders weten hiervan mee te spreken. Druyff deelt mee ${ }^{4}$ ), dat de onderkoning van Patani bij hem op bezoek geweest is, vergezeld van de meeste mandarijnen. Bij de Engelschen, vervolgt hij, is hij niet geweest, ,alsoo die alhier in groote verachtinge zynen" ${ }^{5}$ ). En volgens Coen waren de Engelschen in Patani geheel van kapitaal ontbloot $\left.{ }^{6}\right)$. Hij heeft, na het nemen van den $Z$ warten Leeuw, bevel gegeven, de traditioneele vriendschap en collegiale manieren te verbreken. „Laet haer daer in hun wesen”, aldus zijn opdracht. „Hout u gerust ende schout d' occasie van questye off querelle" "). Geen open strijd dus! Dat vond Coen blijkbaar niet raadzaam, onder 't oog van 't Patanische hof!

Er moest door Jourdain grondig worden ingegrepen. Verontwaardigd over het wangedrag van Gillman, liet hij dezen als gevangene aan boord brengen, en stelde hij een ander in zijn plaats aan. Dit is Adam Denton geweest, onder wiens leiding ook de goederen aan land gebracht werden ${ }^{8}$ ). Nadat Jourdain aldus de factorij gereorganiseerd, een bezoek aan de koningin gebracht en haar met een groot geschenk vereerd had, lagen de schepen op 26 Juli klaar om te vertrekken ${ }^{9}$ ).

Maar ze zouden hun noodlot niet ontgaan. Juist op denzelfden dag namelijk verscheen Hendrik Janssen voor Patani met de Engel, de Bergerboot en de Morgenster, na de Jager te Jambi te hebben achter-

1) Zie over den tocht van de Sampson en de Hound: Anderson, p. 73; Journal Jourdain, p. LXXI en appendix F, $2^{\mathbf{e}}$ stuk; Cal. St. P. 1617-'21, N ${ }^{\circ}$ $775, \mathrm{~N}^{\circ} 787$ en $\mathrm{N}^{\circ} 846$; Extractbrief van John Jourdain naar Patani, aan boord van de Sampson in „Saddon Roade”, 6 Mei 1619.

2) Vgl. p. 209, noot 4.

3) Zie: Anderson, p. 73-74; Journal Jourdain LXXI; Cal. St. P. 1617-'21, $\mathrm{N}^{\circ} 846$.

4) Gerrit Frederiksz. Druyff aan beww. kamer Amst., Patani, 26 Mt. 1619.

5) In Siam moet de toestand der Engelschen volgens Druyff's schrijven beter geweest zijn.

6) J. P. Coen aan beww., Jacatra, 5 Aug. 1619 (Col. Coen I, p. 445 v.).

7) Copiebrief van J. P. Coen aan Gerrit Frederiksz. Druyff, Jacatra, 2 Juni 1619 (Col. Coen II, p. 555 v.).

8) Zie: Anderson, p. 74; Journal Jourdain, p. LXXI ; Cal. St. P. 1617-'21, $\mathrm{N}^{\circ} 747$ en $\mathrm{N}^{\circ} 846$; Jan van Hasel aan J. P. Coen te Jacatra, Sangora, 4 . Oct. 1620.

9) Journal Jourdain, p. LXXI en appendix $F 2^{\text {e }}$ en $4^{\mathrm{e}}$ gedeelte. 
gelaten ${ }^{1}$ ). Jourdain zag dadelijk in, dat zijn positie tegenover de Nederlanders zwak was; de ligging van zijn schepen bij de wal was nadeelig; men ried hem dan ook, zee te kiezen, omdat daar met meer voordeel gestreden zou kunnen worden. Maar de bevelhebber vond dit smadelijk tegenover de inwoners van Patani, die zijn vertrek als een vlucht zouden beschouwen: ,it should never be reported that he would run away from a Fleming". Zoo wist in den volgenden nacht Hendrik Janssen zijn schepen tot vlak bij de Engelsche te brengen, op ongeveer een pistoolschot afstand. Bij het aanbreken van den $27^{\text {en }}$ Juli begon dan ook het gevecht onder voor de Engelschen zeer ongunstige omstandigheden. „Naerdat ter wederzyden drie glasen lanck ${ }^{2}$ ) seer geweldich gevochten hadden", aldus geeft Coen verslag aan bewindhebbers, ,gaven 't d' Engelsen op, seer ijsselijck om lijffsgenade biddende". In waarheid is de houding onzer vijanden stellig waardiger geweest. $\mathrm{Na}$ zich met groote dapperheid zoo lang mogelijk te hebben verdedigd, heschen ze de witte vlag, en begonnen te onderhandelen. Namens Jourdain werd van diens schip de Sampson Thomas Hackwell naar het Nederlandsche admiraalsschip de Engel gezonden om tot voorwaarden van overgave te komen. Vertrouwend op den hierdoor ontstanen wapenstilstand vertoonde Jourdain zich daarna openlijk voor de groote mast van zijn schip. Plotseling werd hij daar echter door een Hollandschen musketkogel onder zijn hart getroffen, en wel zoo ernstig, dat hij binnen een half uur aan de gevolgen overleed. Over dit onverwachte en ernstige feit loopen de meeningen van Engelschen en Nederlanders uiteen. Dat er reeds onderhandelingen gaande waren, toen Jourdain het doodelijke schot ontving, daarover heerscht eenstemmigheid. De Compagnie verklaart in 1620 aan haar dan bevriende Engelsche zustervereeniging, dat men op de Morgenster nog niet op de hoogte moest geweest zijn van de loopende onderhandelingen, en dat nog verschillende zoowel kanon- als musketschoten van uit dat schip waren gelost, waarvan er een bij toeval Jourdain had getroffen. De Engelschen gelooven niet, dat Jourdain toevallig getroffen werd, maar dat ,the Flemmings espying him, most treacherously and cruelly shot at him with a musket". En zorgvuldige vergelijking van de gegevens maakt mij geneigd, de Engelsche opvatting waarschijnlijker te achten dan de Nederlandsche.

In den slag bij Patani hadden de Engelschen behalve hun twee

1) Zie p. 98 .

2) Van Engelschen kant wordt opgegeven vijf glazen, wat dus niet is vijf uren (zooals Anderson, p. 75, en Wood, p. 167, zeggen) maar $2 \frac{1}{2}$ uur. 
schepen 39 dooden verloren, terwijl ongeveer 50 personen waren gekwetst, schrijft Coen, en deze getallen zullen wel ongeveer juist zijn. Aan Hollandschen kant stonden daar tegenover negen of tien dooden en eenige gekwetsten. Coen is overtuigd geweest, dat met John Jourdain een uiterst schadelijk en ook persoonlijk tegenstander was weggevallen. „Haren overste Jan Jordain”, aldus aan Van Speult, „de voorneemste autheur van alle dese onheylen (die niet ontsach uut te geven, dat hy expres gecomen was om my te straffen) is daer gebleven". Evenzeer beschouwt hij het gebeurde als een belangrijke winst voor ons prestige. ,'t Is, de Heere zij loff, alsoo geluct, tot een groote schande voor d'Engelsen, want zyluyden wonderlijcken opgegeven hadden, seer vileyn ende schandelijck van ons spreeckende, als oock hoe onse vlote voor Jacatra verslagen hadden, ende dat voor geen thien Nederlantse schepen wijcken souden", aldus wederom aan bewindhebbers ${ }^{1}$ ).

De Pataniërs hadden natuurlijk een zoo belangrijke gebeurtenis, die zich vlak bij hun stad afspeelde, met ongewone belangstelling gevolgd. „Meer dan 20000 Patanesen”, zegt Coen, ,waren op de strant dit gevecht aensiende, met d'onse, aldaer residerende, wenschende, dat het Godt gelieffde, de victorie aen de Nederlanders te geven". En deze brave inlandsche vrienden toonden dan ook een gepast enthousiasme over den afloop! „Dat d' insolente hovaerdye van d' Engelsen met soo clenen advantage van de slechte, eenvoudige Nederlanders alsoo overwonnen wierd, is de Patanesen soo groten vreuchde geweest, dat daervan publycke liedekens op haer wyse gemaeckt hebben". Alleen het hof toonde zich aanvankelijk bedenkelijk gestemd: waar moest het heen met de Patanische opperhoogheid en neutraliteit, als dergelijke gevechten ongevraagd op de reede van de stad konden geleverd worden! Hollandsche verontschuldigingen hielpen echter zeer om de stemming milder te maken ${ }^{2}$ ).

Het is niet gemakkelijk, de waarde te bepalen van den buit, welke

1) Vgl. over den slag bij Patani: De Jonge: Opkomst, IV, p. CXVIII; Anderson, p. 74 v.; Wood, p. 167; Tiele: Eur., 5, II, p. 231 (Tiele zegt ten onrechte, dat Hendrik Janssen met zijn schepen $27 \mathrm{Juli}$ voor Patani kwam); MacLeod, I, p. 255; Heeres: Hendrik Janssen, p. 126 v.; Colenbrander: Kol. Gesch., II, p. 113 (Colenbrander stelt ten onrechte het gevecht op 26 Juli); Journal John Jourdain, p. LXXII v. en appendix F; Cal. St. P. 1617-'21 No $845, N^{\circ} 846, N^{\circ} 877, N^{\circ} 878, N^{\circ} 888$; Copie-res. van G.-G. en Raden, fort Jacatra, 14 Nov. 1619 (Col. Coen III, p. 552 v.); Copiebrief van J. P. Coen aan H. van Speult op Amboina, Jacatra, 21 Nov. 1619 (Col. Coen II, p. 600 v.); J. P. Coen c.s. aan beww., Jacatra, 22 Jan. 1620 (Col. Coen I, p. 508 v.).

2) J. P. Coen c.s. aan beww., Jacatra, 22 Jan. 1620 (Col, Coen I, p. 508 v.). 
den Nederlanders uit de beide veroverde schepen in handen viel: de talrijke taxaties hierover loopen zeer uiteen. Toen het later namelijk op schadevergoeding aankwam, was 't in 't belang der Engelschen, het bedrag zoo hoog mogelijk op te drijven, in dat der Nederlanders, een lage som te noemen! Zoo zal een schatting van omstreeks $\mathrm{f} 44000$, waartoe we op grond van Nederlandsche gegevens zouden komen, wel aan den lagen kant zijn ${ }^{1}$ ). Wat Coen nog in 't bijzonder interesseerde, dat waren de in de Sampson buitgemaakte papieren : resolutiën, missiven, contracten en andere, waaruit hij de rechtvaardiging putte van het wantrouwen, dat hij tegenover de Engelschen steeds betoond had. Ze bleken van plan te zijn, schreef hij, zich meester te maken van Compagnie's middelen ,ende den staet van de generale Compagnie t' enemaele te ruineren, ende dat op seeckere gesochte actie ende veel openbare logenen, daermede wy seer valschelijck beschuldicht werden, ende zyluyden soecken de macht van Engelandt, ende alle de werelt te abuseren ${ }^{2}$ ).

De behaalde overwinning stemde Hendrik Janssen tot mildheid jegens zijn scheepsvolk. Op 4 Augustus werd door hem aan de schippers en kooplieden van zijn schepen ten geschenke gegeven aan kleedjes een waarde van 625 gulden, zes stuivers en vier penningen, aan de matrozen voor f 3475.4.-, terwijl eenige aanzienlijke Pataniërs, wier voorspraak natuurlijk bij de gepleegde neutraliteitsschennis van groote beteekenis was, werden bedacht met een waarde van $f$ 675.19.12, eveneens in kleedjes ${ }^{3}$ ).

1) Discours van 't gepasseerde tusschen de gecommitteerden der Eng. en Ned. Comp. in Indië, sedert 22 April 1620 tot 20 Sept. 1621, fort Batavia, 20 Sept. 1621; Factuur der koopmanschappen, getrokken uit de generale inventaris bij de gecommitteerde van Hendrik Janssen op 4 Aug. 1619 voor Patani opgenomen van alle koopmanschappen in de Sampson en Hound veroverd; Notitie wat in verscheiden aangehaalde schepen, zoo in Banda als gedurende de oorlog bevonden en tot onze handen gekomen is, onderteekend door Pieter de Carpentier en Dedel; Notitie van contanten, koopmanschappen enz., welke die van de Eng. Comp. in rekening brengen bij de Ned. Comp. voor en gedurende de oorlog veroverd te zijn; Rekening in 't Engelsch van contanten, goederen, koopmanschappen en schepen, die de Engelschen van de Ned. Comp. eischen; Demands made by the president and counsel in behalf of the English Company for restitution and satisfaction of the ships and goods taken; Specificatie van alle veroverde Engelsche goederen zoo die hier in Indië getaxeerd en gebeneficeerd zijn, onderteekend door Jacques Specx en Antonio van Diemen; Cal. St. P. 1617-'21 $\mathrm{N}^{\circ} 846$ en $\mathrm{N}^{\circ} 1097$.

2) J. P. Coen c.s. aan beww., Jacatra, 22 Jan. 1620 (Col. Coen I, p. 508 v.).

3) Zie: Notitie van de schenkages door Hendrik Janssen van de goederen, in de Sampson en de Hound veroverd, 4 Aug. 1619. 
Van de gevangengenomen Engelschen werden de meesten aan land gezet, met uitzondering van eenige timmerlieden en andere van de voornaamste opvarenden, die men meenam naar Japan, om ze vandaar naar Jacatra te brengen, ten deele om het nut, dat van hen getrokken kon worden, ten deele ook, zooals van Engelschen kant gezegd wordt, voor de ,triumph and glory” der Nederlanders. In Japan gelukte het nog aan drie der meegevoerde gevangenen, naar de Engelsche loge te ontsnappen. $\mathrm{Zij}$, die in Patani aan land gebleven waren, hadden, mogen we den Engelschen berichten geloof schenken, nog den ergsten overlast van de Hollanders te lijden. Dezen, de meerderen in getalsterkte, zouden op straat hun zwaard tegen de Engelschen hebben getrokken en gedreigd hebben, hun huizen te verbranden, totdat ze door de koningin in bescherming werden genomen, die hiervoor echter, tot verontwaardiging der Engelschen, een hoogen prijs eischte ${ }^{1}$ ).

De tijding van de Nederlandsche overwinning werd op 13 November 1619 in Jacatra aangebracht met een expresse prauw, die daarvoor was afgestaan door „Padoucka Sarinara”" $)$. Ook hier leidde de vreugde over het nieuws tot het geven van geschenken. Er werd besloten, aan de brengers ervan, Adriaen Adriaensz., opperkoopman van de Morgenster, en Hendrick van Lier, bottelier, te vereeren ,voor haer moeyten ende extraordinarie dienst" respectievelijk 40 en 20 realen van achten. Ook de Pataniërs, die mee waren gekomen, werden bedacht met cadeau's van grootere of kleinere waarde, terwijl aan Sirinara voor zijn welwillendheid gezonden werd een diamantring, vijf ellen rood scharlaken, een verguld gegraveerd vogelroer en een roode fluweelen bandelier ${ }^{3}$ ).

1) Zie over 't bovenstaande: Anderson, p. 75 v.; Cal. St. P. 1617-'21 No 817, $\mathrm{N}^{\circ} 820, \mathrm{~N}^{\circ} 948, \mathrm{~N}^{\circ} 1140$; J. P. Coen c.s. aan beww., Jacatra, 22 Jan. 1620 (Col. Coen I, p. 508 v.).

2) Zie over Sirinara p. 6. Padoucka is in den regel een inlandsche vorst. Dit kan hier echter niet het geval zijn.

3) Over de prauw en de geschenken: Copie-resolutie van G.-G. en Raden, fort Jacatra, 14 Nov. 1619 (Col. Coen III, p. 552 v.); Copiebrief van J. P. Coen aan A. J. van der Dussen te Jambi, Jacatra, 19 Nov. 1619 (Col. Coen III, p. 594 v.); idem aan H. van Speult op Amboina, Jacatra, 21 Nov. 1619 (Col. Coen II, p. 600 v.) ; Copie-res. van G.-G. en Raden, fort Jacatra, 23 Nov. 1619 (Col. Coen III, p. 556 v.); Copiebrief van Pieter de Carpentier „ter ordonnantie van d'heer generael" aan Gerrit Frederiksz. Druyff te Patani, Jacatra, 21 April 1620 (Col. Coen II, p. 688 v.) ; Copiebrief van J. P. Coen aan den orangcaya Padoucka Sarinara te Patani, Jacatra, 15 Mei 1620 (Col. Coen II, p. 710). 
Dat Hendrik Janssen zelf na zijn terugkomst in blakende gunst stond, behoeft geen betoog. Als ,eerlijcke vereeringh" ontving hij ,een goude ketting van 600 Gld.” ${ }^{1}$ ). Maar ook aan de „opperhoofden en voornaamste officieren" van de schepen werden belooningen toegekend, zooals per resolutie van 20 December 1619 billijk werden geoordeeld na „so heerlyke exploieten ende victorien”: den opperkooplieden en schippers ieder 100 realen, aan onderkooplieden, opperstuurlieden en predikanten ieder 50 rijksdaalders, en aan de assistenten, onderstuurlieden en ziekentroosters elk 25 realen $^{2}$ ).

$\mathrm{Na}$ den slag bij Patani werd de verhouding tusschen de beide concurreerende loges scherper dan ooit. In de plaats van Gillman stond nu de stellig bekwamere Adam Denton, geholpen door John Jourdain jr., een neef van den gedooden bevelhebber. De opleving der Engelsche factorij, die dan duidelijk waar te nemen is, ergert natuurlijk Druyff, die verklaart, dat Denton „bij al de werelt voor een groot, dol, los hooft bekent is". Jan van Hasel, ons logehoofd in Sangora, uit zich in denzelfden geest over de Engelschen in Patani, die staan onder een ,superb overhooft, genaemt Adam Denton, welck als geterchde vijanden van spijt schenen te bersten". Om ons den Chineeschen handel voor Sangora en Ligor te onderscheppen, hadden de Engelschen van Sirinara een groote galei gekocht, die bemand werd met Engelschen, „lascars” ${ }^{3}$ ) en ,verlopene Specken” ${ }^{4}$ ). Gelukkig evenwel bezaten de onzen daartegenover het jacht Klein Hollandia, dat immers voor langeren tijd naar Patani was gezonden om zoo noodig militaire hulp te bieden, speciaal tegen de Portugeezen $\left.{ }^{5}\right)$. Toen de Engelschen alzoo niets konden uitrichten, aldus Van Hasel, ,hebben haere tongen te werck gestelt”, om ons bij de inlandsche grooten "stinckende te maecken”, met ,groove ende on-

1) Zie p. 96. Verder: Heeres: Hendrik Janssen, p. 127; Copiebrief van J. P. Coen aan den gouverneur Speult op Amboina, Jacatra, 13 Dec. 1619 (Col. Coen II, p. 618 v.); Copie-res. van G.-G. en Raden, in 't schip Dordrecht voor Bantam, 20 Dec. 1619 (Col. Coen III, p. 566 v.). De verklaring van Cassarian David (Journal Jourdain, appendix F, laatste stuk), dat Coen „gratified him with fourteene hundred gilders in a chaine of gold, putting it himselfe about his necke", lijkt me min of meer fantastisch.

2) Heeres: Hendrik Janssen 1.1.; Copie-res. van G.-G. en Raden, in 't schip Dordrecht voor Bantam, 20 Dec. 1619 (Col. Coen III, p. 566 v.). Volgens den in noot 1 genoemden Cassarian David (1.1.) werd ook de man, die het doodelijke schot op Jourdain gelost had, beloond door Coen met ,one hundred pieces of eight" (d.i. realen van achten).

3) Inlandsche schippers.

4) D.i. Portugeezen.

5) Zie p. 98. 
beschaemde leugenen": het is ons reeds bekend, hoe ze het trachtten voor te stellen, alsof de Hollanders, wanneer ze zich in Sangora versterkten, in deze plaats een tweede Jacatra zouden stichten; we weten ook, dat hun pogingen, onze positie door deze redeneering te ondermijnen, op niets uitliepen $\left.{ }^{1}\right)^{2}$ ).

In 1620 bracht, zooals we zagen, het schip de Sampson in Mei in Patani het bericht, dat door de beide Compagnieën in Europa besloten was, de onderlinge vijandelijkheden en concurrentie te staken $^{3}$ ); samenwerking zou er voor in de plaats komen. De bepalingen van dit verdrag, gesloten op 17 Juli 1619, behelsden o.a., dat in de Molukken, Ambon en Banda den Engelschen 1/3 van den handel toegezegd werd; voor de Hollanders bleef $2 / 3$ gereserveerd. De peperhandel op Java zou half om half worden genoten ${ }^{4}$ ). Dat dit tractaat allerslechtst paste bij Coen's voornemen, de Engelschen met alle hem ten dienste staande middelen uit Indië te verdrijven, en dat hij, bij de krijgslust, die door de laatste gebeurtenissen aldaar was opgewekt, zich met bijtende ironie tegen zijn meesters in patria uitliet, mag bekend worden verondersteld. Hij had zich echter bij de voldongen feiten neer te leggen en moest trachten, ook daar, waar het tractaat geen duidelijke aanwijzingen gaf, met de Engelschen tot een modus vivendi te komen. Tot deze streken behoorde ook Patani. Hij begon derhalve eerst met aan Druyff in dien geest te laten schrijven. Dezen werd aanbevolen, tot nader order ,,met den anderen in ruste ende vrede te leven", evenwel: een oog in 't zeil houdende $!^{5}$ ). Later ${ }^{6}$ ) preciseert Coen de te volgen tactiek nader. Met de Engelschen moet Druyff tot overeenstemming komen om prijsopdrijving bij inkoop tegen te gaan: ieder heeft dan 't recht, een deel van den gemeenschappelijken inkoop voor zich te nemen naar rato van zijn beschikbaar kapitaal. Spoedig komt hij hierop echter in nadere brieven terug.

1) Zie p. 107 .

2) Vgl. over onze verhouding tot de Engelschen na den slag bij Patani: Anderson, p. 77, 79 v.; Cal. St. P. 1617-'21 No 747 en No 851 ; Gerrit Frederiksz. Druyff aan J. P. Coen te Jacatra, Patani, 8 Mt. 1620; Jan van Hasel aan J. P. Coen te Jacatra, Sangora, 4 Oct. 1620.

3) Zie p. 99 en p. 115.

4) Zie Colenbrander: Kol. Gesch. II, p. 114.

5) Copiebrief van Pieter de Carpentier ,ter ordonnantie van d' heer generael" aan Gerrit Frederiksz. Druyff te Patani, Jacatra, 21 April 1620 (Col. Coen II, p. 688 v.).

6) Copiebrief van J. P. Coen aan G. F. Druyff te Patani, Jacatra, 15 Mei 1620 (Col. Coen II, p. 707 v.). 
Hij wijst er dan op ${ }^{1}$ ), dat de door hem aanbevolen methode niet door het tractaat van 1619 werd geëischt, en dat Druyff ten slotte volkomen vrij is, te handelen, zooals hij wil. Hij mag dus, als 't met voordeel kan, buiten de Engelschen om handelen, ja, dit is zelfs gewenscht, daar men toch reeds op Java en in 't Oosten tegen recht en billijkheid hun zooveel heeft moeten toestaan. Houd goede vriendschap, zegt Coen, ,mits sorge dragende, dat syluyden u niet en vercloecken".

Hoe in Patani en omstreken het nieuws van den vrede opgevat werd? Jan van Hasel in Sangora betuigt in een brief aan Coen zijn tevredenheid ermee, en zegt ook, onder de Chineezen groote voldoening erover te hebben bemerkt, want ,dergelijcke tragedische spelen, haer op Java als voor Patanij gethoont, is lichtelijck te gelooven in dese vreesachtige natie cleen behagen geeft" ${ }^{2}$ ). Zuiniger is Druyff in Patani. „Belangende overgroote vrientschap met de Steerten ${ }^{3}$ ) te houden: soodanich zij ons bewijsen, zullen haerluijder niet min doen: beginnen 't groot hart, dat dus lange in de schoen gesteecken heeft, hart weder op te steecken" $\left.{ }^{4}\right)$. Een uiting, die meer den geest van Coen ademt dan een gezindheid, die tot vruchtbare samenwerking kan leiden.

Inderdaad is dan ook in den tijd na 't bekend worden van 't verdrag van faire handelsbetrekkingen geen sprake geweest. Coen zelf geeft de leiding. Druyff, zoo schrijft hij, moet zien, ,d' aenplantinge van peper op alle plaetsen met behendicheyt te voirderen", d.w.z: zoo, dat de Engelschen er niet achter komen. Daartoe moet hij op alle ervoor in aanmerking komende plaatsen ,secretelijck goede somme gelt beschicken”, en bij den inkoop niet dan ,getrouwe, cloecke ende secrete persoonen" gebruiken ${ }^{5}$ ). En Druyff is in dit opzicht aan Coen gewaagd. In zijn brief d.d. 4 November $1620^{6}$ ) schrijft hij hem met voldoening, hoe hij de Engelschen er tusschen genomen heeft bij de komst van een Chineesche jonk: toen de Engelschen deeling van alle dienstige waren verzocht hadden, had hij hierin toegestemd, maar van den schipper, dien hij goed kende, gedaan gekregen, dat alleen goederen van mindere kwaliteit in de deeling betrokken werden, ter-

1) Copiebrief van J. P. Coen aan G. F. Druyff te Patani, Jacatra, 23 Juni 1620 (Col. Coen III, p. 745 v.); idem aan denzelfde, Jacatra, 3 Juli 1620.

2) Jan van Hasel aan J. P. Coen te Jacatra, Sangora, 4 Oct. 1620.

3) Bekende scheldnaam voor de Engelschen.

4) Gerrit Frederiksz. Druyff aan J. P. Coen, Patani, 4 Nov. 1620.

5) Copiebrief van J. P. Coen aan G. F. Druyff te Patani, Jacatra, 3 Juli 1620.

6) Zie den brief, genoemd in noot 4 . 
wijl de rest aan de Nederlanders alleen werd geleverd. Een belangrijk punt voor ons was het ook, den Engelschen den handel in Sangora te blijven beletten, waar we tot aan dien tijd, anders dan in Patani, alléén een factorij gehad hadden. „Maeckt insonderheyt”, aldus Coen aan Druyff, ,dat sylieden in Sangora, Bordelon, Ligor ende andere omleggende quartieren niet comen te nestelen" ${ }^{1}$ ). Dat ze uit Sangora werden geweerd, was echter den Engelschen een reden tot groote ergernis. Ze brachten hierover zelfs een klacht voor den gemeenschappelijken Raad van Defensie, waarop Coen weer het antwoord niet schuldig bleef ${ }^{2}$ ). Zoo hadden in Patani de Engelschen nog allerminst reden tot tevredenheid over hun bondgenooten. „But let them run on in their pride, and think themselves the better men, but they will much deceive themselves", aldus hun factorijhouders in een brief naar $\operatorname{Siam}^{3}$ ).

Maar ook van Hollandsche zijde regende het klachten ${ }^{4}$ ). Druyff, die gewend is, zich scherp uit te drukken, doet zich te goed aan hevige invectieven, als hij 't heeft over de daden van Adam Denton, een goddelooze leugenaar, een fielt, zooals hij zegt. - Deze haat wordt eenigszins begrijpelijker, als we denken aan de rol, die Denton bij het nemen van de Zwarte Leeuw gespeeld had - . Hij had de Nederlanders bij den koning van Ligor ,,vuijl en leelijck gemaeckt”; hij had een Cambodjasche jonk, waaruit de onzen \pm 100 picol benzoë hadden gekocht, laten leegplunderen, daar de opvarenden niet ook aan de Engelschen geleverd hadden; verder had hij nog een Chineesche jonk, die uit Sangora zeil ging, door Chineesche spionnen doen waarnemen, en door 't schip de Hope ${ }^{5}$ ) laten leegplunderen, alweer met de motiveering, dat ze met de Engelschen geen handel wilde drijven. Waren we nog met de Engelschen op voet van oorlog geweest, zoo verzucht Druyff, dan is 't zeker, dat Denton, die ook bij de inlandsche grooten ,,voor een opgeblasen hoovaerdigen leugenaer bekent is”, „zijnen hoochmoedigen herte en fenijnigen steert wel zoude in den dwanck gehouden hebben". Gelukkig is Denton uit Patani verdwenen en door een factorijhouder opgevolgd, die zich bescheidener schijnt te zullen gedragen dan de vorige "war vogel" ${ }^{6}$ ).

1) Copiebrief van J. P. Coen aan G. F. Druyff te Patani, Jacatra, 3 Juli 1620.

2) Cal. St. P. 1622-'24 No 46; J. P. Coen c.s. aan beww., Jacatra, 8 Jan.

1621 (Col. Coen I, p. 606 v.).

3) Cal. St. P. 1617-'21 No 1007.

4) Vgl. ook p. 115 v.

5) Zie beneden.

6) Gerrit Frederiksz. Druyff aan J. P. Coen, Patani, 4 Nov. 1620. 
Met dezen opvolger moet John Jourdain jr. bedoeld zijn, die inderdaad in 1620 op Denton is gevolgd ${ }^{1}$ ). Maar ook tijdens het bewind van Jourdain heeft Druyff nog geen rust. Een heele reeks van klachten uit hij later ten overstaan van eenige leden uit den dagelijkschen raad van 't fort Batavia over Engelsche handelspractijken in ' $t$ jaar 1621, welke alle getuigden van dezelfde tendenz: den Hollanders den handel zooveel mogelijk te bemoeilijken en de prijzen voor hen op te drijven ${ }^{2}$ ).

Vragen we ons af, hoe de Engelsche handel in deze laatste tijden in Patani geweest is, dan zouden we oppervlakkig geneigd zijn, tot bloei te concludeeren. Evenals namens de Nederlandsche Compagnie ${ }^{3}$ ) verschenen er namelijk ook namens de Engelsche tal van schepen, en wel in 1620 de Royal James ${ }^{4}$ ), de Unicorn ${ }^{5}$ ), de Hope ${ }^{6}$ ) en de Clove $^{7}$ ), in 1621 de Exchange $^{8}$ ) en de Peppercorn ${ }^{9}$ ), terwijl in 1622 naar Patani vertrok de Fortune ${ }^{10}$ ) en waarschijnlijk in 1623 de

1) Zie over deze vervanging ook de reis van kapitein Pring in Purchas V, p. 43; Cal. St. P. 1617-'21 $\mathrm{N}^{\circ} 883, \mathrm{~N}^{\circ} 917, \mathrm{~N}^{\circ}$ 921. Wanneer Denton Patani verlaten heeft, is niet precies uit te maken. 3 Juni 1620 is hij er nog; 26 Nov. staat Jourdain reeds aan 't hoofd. Het lijkt me niet onwaarschijnlijk, dat Denton's (overigens door hem begeerd) ontslag met de Hollandsche Morgenster is gezonden (zie p. 100). Van Jourdain wordt getuigd, dat hij was "given over to his pleasure" (Anderson, p. 85).

2) Verklaring van Gerrit Frederiksz. Druyff voor eenige leden uit den dagelijkschen raad van 't fort Batavia; fort Batavia, 8 Febr. 1622.

3) Zie p. 99 v.

$4)=$ de "little James" (zie p. 206)? De Royal James is waarschijnlijk \pm 3 Mei 1620 vertrokken naar Patani en Japan onder kapitein Pring. Aankomst in Patani 4 Juni, vertrek 10 Juni. Vgl. Anderson, p. 81 v.; Purchas V, p. 43 en 146; Copiebrief van J. P. Coen aan Gerrit Frederiksz. Druyff te Patani, in de Nieuw Bantam tusschen Bantam en Jacatra, 3 Mei 1620 (Col. Coen II, p. 702 v.); idem aan J. Specx te Firando, zelfde plaats, 3 Mei 1620 (Col. Coen II, p. 703 v.); Gerrit Frederiksz. Druyff aan J. P. Coen, Patani, 4 Nov. 1620.

5) Waarschijnlijk \pm 3 Mei 1620 weggevaren naar Patani en Japan (Purchas V, p. 146; de beide copiebrieven van Coen, genoemd in noot 4).

6) Vertrok 31 Mei 1620 van Jacatra. Is op 21 Oct. al weer weg uit Patani (Purchas IV, p. 544; de brief van Druyff, genoemd in noot 4).

7) Vertrok 26 Juni 1620 uit Jacatra naar Jambi en Patani. Is op 21 Oct. al in Patani gekomen, en op 4 Nov. alweer vandaar vertrokken. (Cal. St. P. 1617-'21 $\mathrm{N}^{\circ} 88.3$ en $\mathrm{N}^{\circ} 917$; de brief van Druyff, genoemd in noot 4).

8) Was op 23 Mei 1621 juist in Patani aangekomen (Cal. St. P. 1617-'21 $\mathrm{N}^{\circ}$ 1007).

9) Was 7 Juni 1621 reeds in Patani, en bestemd voor Japan en de kust van China. 11 Juni uit Patani vertrokken (Cal. St. P. 1617-'21 N 1012 en $N^{\circ} 1069$ ).

10) Niet vroeger dan 18 Juni 1622 van Batavia weg met bestemming naar Siam, om op terugreis Patani aan te doen (Anderson, p. 84; Copiebrief naar Patani aan Gerrit Frederiksz. Druyff, Batavia, 6 Juli 1622). 
Bee ${ }^{1}$ ). Ook scheen er een goede kans te bestaan, dat naast Patani ook Ligor nog een Engelsche factorij zou krijgen: de vorst aldaar moedigde de vestiging aan, en Druyff zag geen kans, deze te beletten. Maar er is niet van gekomen, en wel wegens gebrek aan kapitaal $^{2}$ ).

Want dit was in Patani het groote gebrek, ondanks het veelvuldige bezoek van schepen: de middelen tot den handel ontbraken meer en meer. Met jaloezie keken de factorijhouders eenerzijds naar de Engelschen in Siam, waar de toestand gunstiger was, anderzijds naar hun Hollandsche collega's ter plaatse, hoezeer ook deze laatsten zich reeds ondermijnd moesten gevoelen ${ }^{3}$ ). Zoo werd reeds in 1620 in Jacatra over Patani gesproken als ,a place of small importance”, waarvan het nut twijfelachtig was ${ }^{4}$ ).

Reeds in ditzelfde jaar waren er dan ook tot Coen geruchten doorgedrongen, als zouden de Engelschen van plan zijn, hun kantoor in Patani te lichten. Met alle middelen wil hij dit plan helpen slagen! „Vordert daertoe”, schrijft hij aan Druyff, „,sooveele met behendicheyt doen condt, verluyden latende, dat wy daertoe mede inclineeren" ${ }^{5}$ ). Ook Jourdain was van meening, dat bij de slechte verzorging, die zijn kantoor ondervond, opheffing de eenige mogelijkheid was ${ }^{6}$ ).

In 1622 werd inderdaad de beslissende stap gedaan. Aan de Fortune werd in Batavia opdracht gegeven, eerst Siam aan te doen, waar de factors afscheid van den koning hadden te nemen en hem hun huis hadden over te dragen tot hun terugkomst, wat wel ad calendas Graecas bedoeld zal zijn, om den koning geen achterdocht te geven. De factors moesten dan scheep gaan, waarop de Fortune op de terugreis Patani moest aandoen om ook daar het kantoor te lichten. De zending van de Fortune slaagde evenwel niet. In Siam wilde de koning de Engelschen voorloopig niet laten vertrekken, terwijl in Patani Jourdain zich bij de koningin in de schuld had gestoken om Chineesche

1) Anderson (p. 85) deelt mee, dat dit schip volgens besluit van Maart 1622 (oude stijl) naar Patani en Siam gezonden werd. Dit zal wel moeten zijn: Maart 1623.

2) Vgl: over Ligor: Tiele Eur. 5, II, p. 307; Cal. St. P. 1617-'21 No 1048, $\mathrm{N}^{\circ} 1069, \mathrm{~N}^{\circ} 1070, \mathrm{~N}^{\circ}$ 1099; Gerrit Frederiksz. Druyff aan J. P. Coen, Patani, 4 Nov. 1620.

3) Vgl. hoofdstuk II e.

4) Vgl. over den slechten handelstoestand: Anderson, p. 82 v.; Cal. St. P. 1617-'21 $\mathrm{N}^{\circ} 883, \mathrm{~N}^{\circ} 973, \mathrm{~N}^{\circ} 1007, \mathrm{~N}^{\circ} 1051$.

5) Copiebrief van J. P. Coen aan G. F. Druyff te Patani, Jacatra, 3 Juli 1620. Vgl. ook Cal. St. P. 1617-'21 No 883.

6) Anderson, p. 82 v.; Cal. St. P. 1617-'21 N 921, N 1013. 
artikelen te kunnen koopen, en vóór zijn vertrek deze schuld moest worden afbetaald ${ }^{1}$ ). Zoo was er nog een nieuwe zending noodig naar de beide factorijen. Hiermee werd het schip de Bee belast, dat nu alle Compagnie's dienaren mee terug moest brengen, en een lading „Japan plate" mee aan boord kreeg om daarmee de schuld aan de koningin van Patani af te doen ${ }^{2}$ ).

De verrichtingen van de Bee zijn mij niet in bijzonderheden bekend; we mogen echter als vaststaand aannemen, dat de beide factorijen, die van Siam en die van Patani, in 1623 gelicht zijn ${ }^{3}$ ).

1) Vgl. over de zending van de Fortune: Tiele Eur. 5, II, p. 307; Anderson, p. 84 v.; Cal. St. P. 1622-' $24 \mathrm{~N}^{\circ} 143, \mathrm{~N}^{\circ} 264, \mathrm{~N}^{\circ} 265$; Copiebrief naar Patani aan Gerrit Frederiksz. Druyff, Batavia, 15 Juni 1622; Copiebrief naar Patani aan Philips Lucasz, Batavia, 17 Juni 1622.

2) Anderson, p. 85.

3) Vgl. Anderson, p. 85 ; Moreland, p. XXXV; Cal. St. P. 1622-'24 No 368. 


\section{ACHTSTE HOOFDSTUK.}

\section{De opheffing van de factorij te Patani.}

We weten, dat het Nederlandsche kantoor van Patani reeds tijdens het laatste bewind van Hendrik Janssen bedreigd werd, en dat het Jan Pietersz. Coen was, die, ofschoon hij de factorij niet steeds even ongunstig gezind was, toch het opheffen van dezen post tot een punt van ernstige overweging maakte ${ }^{1}$ ). En het argument van Janssen, dat de kantoren van Patani en Sangora met geringe bezetting in stand te houden zouden zijn, zoodat we de voordeelen ervan niet aan de Engelschen zouden behoeven te gunnen ${ }^{2}$ ), moet door hem wel zonder veel vertrouwen in de toekomst geuit zijn.

Men kan zich inderdaad begrijpen, dat Coen, die immers de belangen van 't geheel beter overzag dan Hendrik Janssen, van oordeel was, dat aan „de Bocht" van Patani, waar de handel betrekkelijk geringe baten opleverde, te veel kostbaar kapitaal van de Compagnie werd vastgehouden. Hoe hoog deze bedragen waren, daarvoor staan ons een aantal gegevens uit de algemeene boekhouding van de Compagnie ten dienste.

Op de balansen van de generale boeken sedert het jaar 1618 vertoonen de activa van het kantoor, ook wel „effecten” genoemd, een sterk stijgende lijn. Zoo treffen we hiervoor aan op 4 Maart 1618 de som van f 160205.19 .5 , op 15 Juni 1618 f 298204.15.4, op 1 Augustus 1618 f 298444.15 .4 , op 8 Nov. 1618 f 317644.15 .4 , op 28 Januari 1620 f 343941.9 .15 , op 7 Januari 1621 f 470830.15 .13 , op 20 October 1621 f 519105.5 .- Onder activa worden hier verstaan niet de loge zelf, maar uitsluitend of bijna uitsluitend de contanten, de koopmanschappen, en de uitstaande schulden, welke de factorijhouder van Patani dus nog te vorderen had ${ }^{3}$ ).

Indien aan deze bedragen ook steeds stijgende winsten hadden

1) Vgl. p. 80 v. en p. 90 v. Zie ook over de opheffing van de kantoren van Patani, Sangora, Ajudhja en Cambodja in meer algemeen verband mijn artikel: Bezuinigingsmaatregelen etc., p. $15 \mathrm{v}$.

2) Zie p. 92.

3) Specificatie van de laatstgenoemde som aldus: contanten f 167400 . - . koopmanschappen $f 312845.5$. - , uitstaande schulden $f 38$ 860.-. - (Staat van de kantoren in Indië, 20 Oct. 1621. Bij andere kantoren, als Masulipatam, Suratte 
beantwoord, zou Coen, dat is duidelijk, aan opheffing van Patani niet gedacht hebben. Maar Patani werd met Sangora, Siam en Cambodja tot de ,lastige ende gants ondienstige comptoiren" gerekend ${ }^{1}$ ), waar de factorijhouders ,,met eenen blinden yver arbeyden”, ,menende groote eere ende danck ingeleyt te hebben, als de goederen maer door haere hant vercregen worden, hoe diere het oock sy", reden, waarom men het kostelijke kapitaal liever niet meer op deze plaatsen diende te gebruiken, maar het beter geconcentreerd werd op enkele profijtgevende kantoren als die van Koromandel en Suratte ${ }^{2}$ ).

Dat Patani noodzakelijk zou zijn om er de Chineesche artikelen op te koopen, daaraan had reeds Matelief getwijfeld $^{3}$ ), en we weten al, hoe ook in lateren tijd overwogen is, om óf dichter bij China te handelen, óf in dit land zelf toegang te zoeken ${ }^{4}$ ). Het wenschelijkst zou het zijn, den Chineeschen handel geheel te monopoliseeren, en daarvoor den Portugeezen hun bedrijf in Macao onmogelijk te maken. Dit kon gebeuren door deze plaats op hen te veroveren, maar ook indirect, wanneer men hun de vaart op Malakka en Japan wist te beletten. Spanje zou schaakmat gezet kunnen worden door het opvangen der Chineesche jonken, die naar Manilla voeren ${ }^{5}$ ). Voor den peperhandel verder was Patani stellig niet onmisbaar; uit allerlei andere plaatsen van Indië was immers dit artikel te betrekken ${ }^{6}$ ).

En dan moeten we niet vergeten, welk een groote verandering in 1619 was teweeggebracht door het stichten van een vast middelpunt in Batavia ${ }^{7}$ ). Hierheen wilde Coen zooveel mogelijk den handel uit heel Indië trekken, zoodat in 't algemeen de belangrijke kantoren als hulpkantoren van 't centraal rendez-vous moesten worden beschouwd,

enz., vinden we bovendien nog een bedrag voor den post: victualiën, munitie van oorlog, meubelen en andere „nulliteijten”. Een generale balans en staat van de Compagnie in Indië van J. P. Coen, Bantam, 26 Juni 1616, geeft een algemeene omschrijving van de ,effecten": hieronder hooren contante penningen, koopmanschappen en uitstaande schulden, waaronder eenige vivres, op de forten wezende, gerekend zijn, maar geen ammunitie van oorlog, forten, huizen noch schepen. Omtrent de munitie is de boekhouding van 1616 tot 1621 dus niet consequent gebleven).

1) Copie-res. van G.-G. en Raden, fort Jacatra, 4 Aug. 1621 (Col. Coen III, p. 749 v.).

2) Copie van punten, door Coen aan Raden in bedenking gegeven, fort Batavia, 16 Dec. 1621 (Col. Coen III, p. 794 v.).

3) Zie p. 39.

4) Vgl. hoofdstuk III.

5) Groeneveldt, p. 58 v.

6) Zie p. 158 .

7) Vgl. p. 116 
de onbelangrijke echter liefst moesten verdwijnen. En hieronder vielen ook Patani, Sangora, Siam en Cambodja ${ }^{1}$ ). Op den duur moesten de inwoners dier streken bewogen worden, zelf hun goederen naar Batavia ten verkoop aan te brengen; het zou evenwel eenigen tijd moeten kosten, voor men deze gewoonte had doen doordringen; daarom zou het noodig zijn, eerst deze streken nog door schepen en jachten van de Compagnie te doen bevaren ${ }^{2}$ ), ,ter wyle ende tyden ${ }^{3}$ ) de saecken allenskens in 't reyn sullen gebracht wesen" ${ }^{4}$ ). Desnoods zou op de inwoners daartoe pressie moeten worden uitgeoefend, en dit was natuurlijk onmogelijk, zoolang er nog kantoren bestonden, waarvan de factors als gijzelaars zouden kunnen worden beschouwd $\left.{ }^{5}\right)^{6}$ ).

Op 3 en 4 Augustus 1621 vielen in Batavia een paar gewichtige resoluties. $\mathrm{Jacob}^{7}$ ) Colijn Jansz. zou als visitateur de loges van Patani, Sangora, Siam en Cambodja inspecteeren, alsmede den handel, welke in Ligor en Bordelon werd bedreven, en daarbij bevorderen, dat de kantoren het volgende jaar zouden worden gelicht ${ }^{8}$ ). Een uitvoerige instructie van 6 Augustus $^{9}$ ) schreef hem zijn taak in bijzonderheden voor. Hij had zich eerst naar Palembang en Jambi te begeven, en van de laatste plaats met een schip, dat daar het best gemist zou kunnen worden, naar de bocht van Patani te gaan. Hij moest dan de genoemde kantoren inspecteeren, ,de rekeninge overal opnemende ende ernstich op d'administratie, handel ende wandel van een yder lettende; alle fauten, mishandelinge ${ }^{10}$ ) ende groote dispence na behooren bestraffende". Opdat de lichting het volgende jaar zonder

1) Vgl. De Jonge: Opkomst IV, p. CXXXVIII.

2) Vgl. over de rol van de „vrijlieden” hiernaast mijn artikel Bezuinigingsmaatregelen etc., p. $21 \mathrm{v}$.

3) Versta : totdat.

4) Copie van punten, door Coen bij Raden in bedenking gegeven, fort Batavia, 16. Dec. 1621 (Col. Coen III, p. 794 v.).

5) Tiele: Eur. 5, II, p. 306; J. P. Coen c.s. aan beww., Batavia, 16 Nov. 1621 (Col. Coen I, p. 641 v.); De copie der punten van Coen, genoemd in noot 4.

b) Wat Siam betreft, is de meening geopperd, dat het verbranden van onze loge aldaar in 1622 de reden zou geweest zijn tot het besluit, ons kantoor aldaar op te heffen (zie W. Blankwaardt: De factorij der O. I. Compagnie te Ayuthia, Neerlandia 1921, p. 73). Dit kan echter niet als juist worden beschouwd, daar reeds in 1621 de opheffing van 't kantoor, zooals we zullen zien, werd voorbereid.

7) Ook Jacques komt voor.

8) Copie-res. van G.-G. en Raden, fort Jacatra, 3 Aug. 1621 (Col. Coen III, p. 746 v.) ; idem, fort Jacatra, 4 Aug. 1621 (Col. Coen III, p. 749 v.).

9) Copie-instructie van J. P. Coen voor Jacques Colijn, Jacatra, 6 Aug. 1621 (Col. Coen III, p. 70 v.).

10) Versta: verkeerde handelingen. 
nadeelen zou kunnen geschieden, moesten alle uitstaande schulden geind en geen nieuwe gemaakt worden, de onkosten zooveel mogelijk besnoeid en zonder expresse order geen timmering van huizen of anderszins worden verricht. De middelen, waarover de Compagnie er beschikte, moesten in profijtgevende koopmanschappen voor patria worden besteed, inzonderheid peper en Chineesche waren. Men moest vooral zien, den Chineezen bij den peperinkoop voor te zijn; mocht dat echter mislukken, dan moest óf de peper uit de Chineesche jonken worden gelicht en tot lagen prijs betaald, óf de opvarenden met hun lading naar Jacatra worden gedirigeerd, met de waarschuwing, dat later in dergelijke gevallen zelfs geen betaling voor de peper zou worden gedaan! Overal moest Colijn den inlanders aanzeggen, dat de Compagnie de vriendschappelijke handelsbetrekkingen wenschte te onderhouden, ,voor sooveel sonder des Compagnies prejuditie geschieden can", en dat daarom de handel met jachten zou worden gecontinueerd. De inwoners moesten echter worden aangemoedigd, met hun jonken naar Batavia te varen, gelijk ook om overal zooveel mogelijk peper aan te planten. Gerrit Frederiksz. Druyff en Cornelis van Nieuwenroode, onze hoofden in Patani en Ajudhja, wier verbonden tijd verstreken was, moesten zich zoo spoedig mogelijk naar Batavia vervoegen, om daar rekening en verantwoording af te leggen en hun advies aangaande het lichten der kantoren uit te brengen ${ }^{\mathbf{1}}$ ).

Aan Druyff en Van Nieuwenroode werd geschreven, dat ze den visitateur Colijn zooveel mogelijk behulpzaam hadden te zijn, en hem de personen moesten aanwijzen, die ze het geschiktst achtten om, zelf vertrekkende, met het beheer der ,,restanten”, dat zijn de achterblijvende koopmanschappen, te belasten ${ }^{2}$ ). Voorts ging met Colijn de Patanische gezant mee, die het vredesluiten met de Portugeezen in ons hoofdkwartier had moeten verontschuldigen. Hij bracht, zooals we zagen, weinig gunstig bescheid mee, al moest een schenkage onze goede gezindheid bevestigen ${ }^{3}$ ).

We mogen aannemen, dat Colijn op zijn gewichtige zending 6 Aug. 1621 of kort daarna vertrokken is, op de Dolfijn, en dat hij, na een bezoek aan Jambi, van daar uit op de Eenhoorn zijn tocht naar Patani heeft voortgezet $^{4}$ ).

1) Vgl. p. $116 \mathrm{v}$.

2) Copiebrieven van J. P. Coen aan Druyff en Van Nieuwenroode, beide Jacatra, 6 Aug. 1621 (Col. Coen III, p. 72 v.).

3) $\mathrm{Zie}$ p. 115 .

4) Zie p. 101. 
De tocht van Colijn en de onmiddellijke uitwerking ervan zijn ook slechts fragmentarisch uit de gegevens te reconstrueeren. In Patani was reeds op 27 September 1621 aan de Engelschen bekend, dat Druyff zich naar Jacatra moest vervoegen, en zijn secunde, Philips Lucasz $^{1}$ ), de zorg voor het kantoor had over te nemen, met ten hoogste drie andere Nederlanders als helpers. 29 October daaraanvolgende moet Philips Lucasz reeds aan 't hoofd van het kantoor gestaan hebben. 3 Januari 1622 is Druyff reeds in Batavia, daar dan aldaar een stuk door hem mede onderteekend is. Waarschijnlijk is hij 13 December daaraan voorafgaande met de Galjas aldaar aangekomen $^{2}$ ). Cornelis van Nieuwenroode is later in Batavia verschenen, namelijk op 4 Maart 1622, op de Tholen of de Eenhoorn ${ }^{3}$ ). De koning van Siam, vernemende, dat Colijn iemand van zeer hoogen rang was, had hem groote eer bewezen, en wel in 't bijzonder in de hoop, Nederlandsche hulp te kunnen krijgen tegen den vorst van Cambodja, zijn leenman, die zich tot onafhankelijk koning had opgeworpen. Met Van Nieuwenroode had hij daarom twee gezanten en een brief meegezonden naar Batavia, waar begrijpelijkerwijze de Hooge Regeering niet voor de gevraagde hulpverleening gevoelde. Jean Mibaise ${ }^{4}$ ) was na Van Nieuwenroode's vertrek met het bestuur over de loge van Ajudhja belast. Ongeveer twee maanden ${ }^{5}$ ) na Van Nieuwenroode verscheen Colijn zelf in Batavia, later dan men hem verwacht had ${ }^{6}$ ).

Nog voordat definitief tot de opheffing der betrokken kantoren last werd gegeven, oordeelde de Hooge Regeering het noodig, op het hulpverzoek van den koning van Siam te reageeren: daar deze reactie

1) $Z$ ie over hem p. 151 en p. 170 noot 6.

2) Zie p. 100 . Dit mede ter correctie van het door mij in 't artikel Bezuinigingsmaatregelen enz., p. 24, geschrevene. Vgl. Druyff's benoeming tot president van schepenen in Batavia op p. 117.

3) Zie p. $100 \mathrm{v}$.

4) $\mathrm{Zie}$ p. 104 .

5) Tijdens het opstellen van een instructie voor Druyff, d.d. 1 Mei 1622.

6) Vgl. over den tocht van Colijn: Muller : Het land van den Witten Olifant, p. 142 noot 2; MacLeod I, p. 500; Cal. St. P. 1617-'21 No 1099; Copie-protest door Coen aan de Engelsche Compagnie geinsinueerd, Batavia, 3 Jan. 1622 (Col. Coen III, p. 122 v.); J. P. Coen c.s. aan beww., Batavia, 26 Mt. 1622 (Col. Coen I, p. 703 v.); Copie-res. van G.-G. en Raden, fort Batavia, 4 April 1622 (Col. Coen III, p. 848 v.) ; Copiebrief naar Siam aan Jan Mibaise, Batavia, 9 April 1622; Copie-instructie van J. P. Coen voor Gerrit Frederiksz. Druyff, in ambassade naar Palembang etc., Batavia, 1 Mei 1622 (Col. Coen III, p. 167 v.); Copiebrief naar Patani aan Philips Lucasz, Batavia, 1 Mei 1622; idem naar Sangora aan Jan van Hasel, Batavia, 1 Mei 1622; idem naar Cambodja aan Jacob Gaermans, Batavia, 1 Mei 1622. 
een weigering zou zijn, was het goede tactiek, dat deze zoo spoedig mogelijk en op zoo vriendelijk mogelijke wijze te kennen werd gegeven. In April werd daarom de jonk Firando naar 't Noorden gezonden, met de beide Siameesche gezanten; de opvarenden moesten onder beleefd excuus mededeelen, dat de hulpverleening tegen Cambodja aan de Regeering op dien tijd niet gelegen kwam, en, om de vriendschappelijke verhouding te bewaren, den koning van Siam een goede schenkage ter hand stellen. Verder moest de Firandio een cargasoen ter bevordering van den handel aan land zetten, daarentegen die goederen met bestemming naar Japan inladen, welke het aan 't schip Tholen in 1621 niet gelukt was, naar dat land te vervoeren $^{1}$ ).

Kort daarop werd Druyff uitgezonden, om, na Colijn's voorbereidenden tocht, tot de definitieve lichting der kantoren over te gaan. Volgens zijn instructie, gedateerd $1 \mathrm{Mei}$ 1622, moest hij met vier jachten, het Postpaard, de Vos, de Bruinvisch en de Borneo, eerst Palembang aandoen, en daarna Jambi, waar hij de beide laatstgenoemde schepen moest achterlaten, om zich dan met het Postpaard en de Vos naar de Noordelijke kantoren te begeven. Aan de vorsten van Patani, Sangora, Siam en Cambodja moest Druyff meedeelen, dat hij kwam om het volk en de goederen van de kantoren te lichten, „niet omme haere Magesteyten te verlaten, off d'oude vrientschap te breecken, maer om die te vermeerderen ende den handel jaerlijcx met schepen te dryven", terwijl men hoopte, dat later de inwoners zelf den weg naar Batavia zouden weten te vinden! Als 't instantelijk door de vorsten zou worden verzocht, zou Druyff in Siam, Patani of Sangora een paar man mogen achterlaten, zonder eenig kapitaal nogtans. De uitstaande schulden moesten overal geïnd en het beschikbare kapitaal, ook wat door 't Postpaard en de Vos aangebracht werd, besteed worden in profijtgevende waren voor 't vaderland, voornamelijk in peper. Hierop moest Druyff overal „,een eerlijck affscheyt nemen", na te hebben verzocht, onze huizen te willen reserveeren voor den handel, die jaarlijks door onze komende schepen zou worden gedreven. In Patani viel nog een zeer onaangename zaak voor

1) Zie p. 101. Vgl. verder: Copiebrief naar Patani aan Philips Lucasz, Batavia, 1 Mei 1622; idem naar Sangora aan Jan van Hasel, Batavia, 1 Mei 1622; idem naar Siam aan Jean Mibaise, Batavia, 1 Mei 1622; idem naar Patani aan Gerrit Frederiksz. Druyff, Batavia, 2 Juni 1622; J. P. Coen c.s. aan beww., Batavia, 6 Sept. 1622 (Col. Coen I, p. 718 v.) ; J. P. Coen aan beww., in 't schip Mauritius, liggende bij 't eiland St. Helena, 20 Juni 1623 (Col. Coen I, p. 755 v.). 
Druyff te regelen. Een aantal vrijelieden had, met goedvinden van het hoofdkwartier, met klein vaartuig gekruist in de wateren van Malakka, om den handel op die plaats tegen te gaan. Ze mochten evenwel geen schepen aantasten, die op „vrije” plaatsen voeren. Hieraan hadden ze zich echter wel degelijk schuldig gemaakt, zoodat b.v. schepen uit Palembang, Jambi, Johor en Patani door hen waren beroofd, en opvarenden vermoord tegen 't gegeven consigne. Druyff moest nu in Patani bij de koningin, den gouverneur Dato Bandharo en andere geïnteresseerden deze misdaden ,op 't allersoetste” excuseeren, en er op wijzen, dat, mochten er ook personen door de vrijelieden onschuldig zijn omgebracht, anderzijds de „rechtschuldigen” in 't openbaar geëxecuteerd waren. Verder werd datgene, wat de Compagnie nog van de buit in handen had kunnen krijgen, een bedrag van \pm 1100 realen, ter beschikking gesteld om in den vorm van schenkages in Patani te worden verdeeld, al naar de omstandigheden wenschelijk zouden maken. Voor Dato Bandharo, aan wien ook een afzonderlijke brief in bovengemelden zin werd geschreven, was hiervan de waarde van ongeveer 200 realen bestemd.

Een der hoofdaanleggers bij het wanbedrijf tegen de vrije schepen was zekere Jan Steyns geweest. Hem dreigde ook de doodstraf, maar eerst wilde men in Batavia afwachten, hoe de verzoening met de „geof fenceerde" koningen en geinteresseerde vrienden zou afloopen. Daar het echter pijnlijk scheen, dat eventueele handelaars uit Patani hem in Batavia zouden aantreffen, resolveerde men aldaar op 14 Juni, hem voorloopig met een schip vandaar weg te zenden, zonder eenige bediening of gage ${ }^{1}$ ).

Mocht Druyff op zijn zending blijken geven, dat de vrije handel in Batavia gerespecteerd werd, hij moest aan den anderen kant de koningin en alle waardigheidsbekleeders nog eens ernstig verzoeken, er voor te zorgen, dat de vaart op Malakka zou worden gestaakt, daar de Compagnie deze niet zou kunnen dulden: Aan den koning van Siam moest een vereering worden gedaan, en opnieuw worden meegedeeld, dat helaas de gevraagde hulp tegen Cambodja niet kon worden verleend ${ }^{2}$ ).

1) De berichten uit Patani over deze zaak schijnen bevredigend te zijn geweest, want 28 October 1622 schrijft Coen aan Van Speult op Amboina met de Edam, dat aan Steyns toegestaan is, met dit schip naar Banda te varen, om zich daar als vrijman te generen.

2) Vgl. over het zenden van Druyff naar de vier kantoren: Tiele: Eur. 5, II, p. 306; MacLeod I, p. 500; J. P. Coen c.s. aan beww., Batavia, 16 Nov. 1621 (Col. Coen I, p. 641 v.); idem aan dezelfden, Batavia, 26 Mt. 1622 (Col. Coen I, 
Dat de zending van 't Postpaard en de Vos niet alleen een negatief doel had, maar dat men in Batavia den handel met de Noordelijke kwartieren met kracht wilde voortzetten, blijkt uit tal van beschikkingen, die in 1622 nog na de afzending der beide jachten werden getroffen. Eenerzijds was men er op uit, het beschikbare kapitaal speciaal voor den peperinkoop nog eenigszins te versterken, anderzijds om te zorgen, dat er scheepsruimte genoeg in Patani zou zijn om de gekochte goederen naar het hoofdkwartier te transporteeren.

De eerste bedoeling bleek bij de uitzending der jachten Klein Tholen en Sincapura ${ }^{1}$ ) op 3 Juni of kort daarna. Deze waren bestemd voor de kust van China en moesten zich daar voegen bij de vloot van Cornelis Reyersz., die tot taak had, directere handelsbetrekkingen met China te forceeren, en daarbij ook nog o.a. Cornelis van Nieuwenroode als medewerker heeft gehad. Onderweg moesten de twee jachten, die onder leiding van Verhult stonden, Jambi aandoen, en vandaar, zoo noodig, Patani, om daar sandelhout te lossen, indien althans de Chineezen met hun jonken nog niet vandaar waren vertrokken. De opbrengst zou dan weer de koopkracht in Patani kunnen versterken. Liever zou men echter in Batavia zien, dat Adriaen Jacobss. van der Dussen, de factorijhouder in Jambi, de Zwarte Beer, als deze beschikbaar was, naar Patani zond. 300 picol sandelhout moesten er dan in worden overgeladen uit de twee jachten, welke dan direct naar China zouden kunnen varen. De Zwarte Beer zou tevens mee kunnen helpen, de in Patani beschikbare waren in te laden. Het is bij de onvolledigheid der gegevens omtrent de scheepvaart in dat jaar niet altijd gemakkelijk, de ware toedracht van zaken te reconstrueeren, maar we mogen toch wel met zekerheid aannemen, dat de wensch uit

p. 703 v.); Copie-punten, door Coen aan Raden voorgedragen, fort Batavia, 30 Mt. 1622 (Col. Coen III, p. 843 v.) ; Copie-res. van G.-G. en Raden, fort Batavia, 22 April 1622 (Col. Coen III, p. 854 v.); Copie-instructie van J. P. Coen voor Gerrit Frederiksz. Druyff, gecommitteerd naar Palembang enz., Batavia, 1 Mei 1622 (Col. Coen III, p. 167 v.); Copiebrief van J. P. Coen aan Dato Bandharo, gouverneur in Patani, Batavia, 1 Mei 1622 (Col. Coen III, p. 176 v.); Copiebrief naar Patani aan Philips Lucasz, Batavia, 1 Mei 1622; Copiebrief naar Sangora an Jan van Hasel, Batavia, 1 Mei 1622; Copiebrief naar Cambodja aan Jacob Gaermans, Batavia, 1 Mei 1622; Copiebrief naar Siam aan Jean Mibaise, Batavia, 1 Mei 1622; Copiebrief naar Jambi aan Adriaen Jacobss. van der Dussen, Batavia, 2 Juni 1622; Copie-res. van G.-G. en Raden, fort Batavia, 14 Juni 1622 (Col. Coen III, p. 872 v.); Copiebrief naar Jambi aan Adriaen van der Dusse, Batavia, 6 Juli 1622; Copiebrief van J. P. Coen aan gouverneur Speult te Amboina, fort Batavia, 28 Oct. 1622 (Col. Coen III, p. 249 v.).

1) Vgi. p. 169 v. 
het hoofdkwartier in vervulling is gegaan, en dus de Zwarte Beer Patani heeft bezocht ${ }^{1}$ ).

Later in de maand Juni bood de Engelsche Fortune een welkome gelegenheid, berichten uit Batavia naar Patani te zenden ${ }^{2}$ ).

Verder is nog het jacht Westcappel naar Patani gezonden om daar mede te voorzien in het veronderstelde gebrek aan scheepsruimte. Bijzonderheden hierover zijn weinig aan te treffen. Hoewel ik aanneem, dat ' $t$ jacht uit Batavia is gezonden, vond ik dat toch nergens duidelijk vermeld. Ook de datum van vertrek is onbekend, alleen kan deze niet later liggen dan 6 Juli $\left.1622^{3}\right)^{4}$ ).

Maar genoeg reeds van de scheepvaart in 1622 ; we moeten nu nagaan, wat er over het verloop der zending van Gerrit Frederiksz. Druyff bekend is. Dat hij zijn last vervuld heeft, staat vast, wanneer,

1) Vgl. over Klein Tholen, Sincapura en Zwarte Beer: Groeneveldt, p. 72, 80, 110; Copie-res. van G.-G. en Raden, fort Batavia, 27 Mei 1622 (Col. Coen III, p. 867); Copiebrief van J. P. Coen aan commandeur Reyers, Batavia, 2 Juni 1622 (Col. Coen III, p. 190 v.); idem aan Van der Dussen te Jambi, Batavia, 2 Juni 1622 (Col. Coen III, p. 197 v.) ; Copie-res. van G.-G. en Raden, fort Batavia, 2 Juni 1622 (Col. Coen III, p. 868 v.); Copiebrief naar Jambi aan Adriaen Jacobss. van der Dussen, Batavia, 2 Juni 1622; Copiebrief naar Patani aan Gerrit Frederiksz. Druyff, Batavia, 2 Juni 1622; Copie-instructie voor de opperhoofden der jachten Sincapura en Klein Tholen, Batavia, 2 Juni 1622; Copie-res. van G.-G. en Raden, fort Batavia, 3 Juni 1622 (Col. Coen III, p. 870 v.) ; Copie van een ,na ordre" gegeven aan de jachten Klein Tholen en Sincapura, ter ordonnantie van den heer Generaal, Batavia, 3 Juni 1622; Copie-res. van G.-G. en Raden, fort Batavia, 14 Juni 1622 (Col. Coen III, p. 872 v.); Rol der Nederlandsche en Engelsche schepen, in Indië zijnde, 1 Sept. 1622; J. P. Coen c.s. aan beww., Batavia, 6 Sept. 1622 (Col. Coen I, p. 718 v.) ; J. P. Coen aan beww., in 't schip Mauritius bij 't eiland St. Helena, 20 Juni 1623 (Col. Coen I, p. 755 v.).

2) Zie p. 223 en noot 10 aldaar. Vgl. ook: Copiebrief naar Patani aan Gerrit Frederiksz. Druyff, Batavia, 15 Juni 1622; Copiebrief naar Patani aan Philips Lucasz, Batavia, 17 Juni 1622.

3) $\mathrm{Zie}$ over de Westcappel: Copiebrief naar Jambi aan Adriaen van der Dusse, Batavia, 6 Juli 1622; Rol der Nederlandsche en Engelsche schepen, in Indië zijnde, 1 Sept. 1622; J. P. Coen c.s. aan beww., Batavia, 6 Sept. 1622 (Col. Coen I, p. 718 v.); Lijst der Nederlandsche en Engelsche schepen in Indië, 23 Febr. 1623.

4) Weinig verband met ons onderwerp houdt ten slotte het bezoek van de Enkhuizen aan Patani in 't laatst van 1622 of 't begin van 1623. Dit schip, bij de vloot van Reyersz. behoorende, werd in den nacht van 23 November 1622 naar Batavia afgezonden van Peho (zie over dit eiland beneden), om over den slechten toestand aldaar te berichten, zieken mee te nemen, en een aantal Siammers en Japanners in Siam aan land te zetten. Het heeft op zijn tocht ook Patani bezocht, waar het nog gevaarlijk gestooten heeft op de zanden, voor deze plaats gelegen, maar er onbeschadigd afgekomen is (vgl. Groeneveldt, p. 120 v., 517$)$. 
is echter minder gemakkelijk na te gaan. Op een balans van de generale staat van Indië in dato 31 Augustus 1622 figureeren de „effecten" van de kantoren Patani en Sangora nog voor een gezamenlijke som van f $116007.15 .14^{1}$ ), op de balans van de generale boeken van Indië, fort Batavia, 21 Januari 1623, komen de beide kantoren niet meer voor. Het waarschijnlijkst lijkt mij, dat de opheffing van Patani in November 1622 heeft plaats gehad: er bestaat namelijk een bewijs, dat er in Patani een grootboek gehouden is tot 2 November $1622^{2}$ ). In ieder geval meldt Coen op 31 Januari 1623 de kantoren van Patani, Sangora en Siam als gelicht, 1 Februari daaraanvolgende De Carpentier ook dat van Cambodja ${ }^{3}$ ). Verder zal Druyff, als op 2 Januari 1623 in Batavia volgens zijn verzoek wordt toegestaan, dat hij per eerste gelegenheid naar ' $t$ vaderland mag vertrekken, wel bij dit besluit aanwezig geweest en dus van zijn tocht naar 't Noorden teruggekomen zijn $\left.{ }^{4}\right)$.

Bijzondere moeilijkheden had de lichting der kantoren niet meegebracht, evenmin wrok bij de inlandsche vorsten achtergelaten. „Dese lichtinge”, zegt Coen, ,veroorsaeckte grote verwonderinge. Elck seyd sijn gevoelen daervan, doch met goede vrientschap is 't geschiet" ${ }^{5}$ ). Wat Patani betreft, maken we uit een later gegeven ${ }^{6}$ ) op, dat het Druyff zelfs gelukte, van de koningin aldaar bindende beloften te krijgen, dat de handel met die van Malakka gestaakt zou worden.

Siam leverde aan Druyff nog een onaangename verrassing. We zagen, hoe de jonk Firando reeds in April 1622 met de beide gezanten naar Siam was gezonden ${ }^{7}$ ). Bij aankomst vernamen de opvarenden, dat het geheele Japansche kwartier, alsook de huizen en goederen van de Compagnie verbrand waren, doordat in een der Japansche huizen bij ongeluk brand was uitgebroken ${ }^{8}$ ). De Compagnie leed hierbij een

1) Vg1. p. 226.

2) Register van loge-, garnizoen- en scheepsboeken etc., door Dirck van der Lee met 't schip Leiden aan de kamer van Amst. gezonden. Het is waar, dat in een res. van G.-G. De Carpentier en Raden, Batavia, 16 Nov. 1623, nog wordt gezinspeeld op een raad in Patani, die 20 Dec. 1622 vergaderde, maar dit kan de raad van een schip geweest zijn.

3) J. P. Coen aan Pieter de Carpentier en raden van Indië, Batavia, 31 Jan. 1623 (Col. Coen III, p. 288 v.) ; Pieter de Carpentier c.s. aan beww. te Ainst., fort Batavia, 1 Febr. 1623.

4) $\mathrm{Zie}$ p. 117, ook over zijn vertrek daarna met het schip Alkmaar.

5) Coen aan beww., in de Mauritius, bij 't eiland St. Helena, 20 Juni 1623 (Col. Coen I, p. 755 v.).

6) Copie-missive aan de koningin van Patani, Batavia, 7 April 1624.

7) Zic p. 231.

8) Vgl. p. 228 noot 6. 
schade van f 77 554.-10. Dit bracht natuurlijk voor Druyff allerlei extra-regelingen mee. Maar ook het lichten van 't kantoor was hier lastiger dan in Patani, daar de koning instantelijk verzocht, dit niet te doen. Druyff nu meende, na de teleurstelling, die men hem reeds door 't ontzeggen van hulp tegen Cambodja had aangedaan, den vorst tegemoet te moeten komen, door, al werd ook de factorij officieel gelicht, althans een assistent in Siam achter te laten. Deze zou tevens nog goed werk kunnen doen door 't innen van nog uitstaande schulden, samen bedragende $\pm f 16000$, gelukkig te vorderen van ,goede luijden". De bedoeling was, dat 't jacht Westcappel later het bedrag naar Batavia zou brengen ${ }^{1}$ ). Zoo figureert Siam op bovengemelde balans van 21 Januari 1623 nog met een bedrag van $f$ 16141.16.15 voor uitstaande schulden, terwijl volgens een balans van 31 December van dat jaar de zaak nog niet geheel in 't reine was $\left.{ }^{2}\right)^{3}$ ).

In Cambodja had de koning eerst ook bezwaren gemaakt tegen ons vertrek; hij had gaarne het jacht de Vos, toen het zich daar bevond, willen gebruiken voor den oorlog tegen Siam. Het is echter zeer begrijpelijk, dat de opvarenden zich hiertoe niet wilden leenen, en den aandrang van den koning weerstand boden $\left.{ }^{4}\right)^{5}$ ).

Nog een enkel woord over den handel, die in 1622 mede aan Druyff opgedragen was. Men had hiervan begrijpelijkerwijs in Batavia de grootste verwachtingen. Men had berekend, dat de waarde der „,restanten” in de kantoren van Patani, Sangora en Siam, vermeerderd nog met wat de jonk Firando naar Siam had gebracht, en wat Druyff bij zijn vertrek uit 't hoofdkwartier meekreeg $\left.{ }^{6}\right)$, een bedrag vertegenwoordigde van $f$ 310332.4.6. Trok men hier het cargasoen af, dat

1) De Westcappel kwam 18 Maart 1623 van Siam in Batavia aan.

2) Hierop staat namelijk nog een post: uitstaande schulden f 1200 , met bovendien aan kwade en desperate schulden $f$ 482.19.15.

3) Vg1. over Siam: Tiele: Eur. 5, II, p. 306; Groeneveldt, p. 517; MacLeod I, p. 500; Balans der generale boeken van Indië op 21 Jan. 1623, fort Batavia; Pieter de Carpentier c.s. aan beww., fort Batavia, 1 Febr. 1623; J. P. Coen aan beww., in de Mauritius bij 't eiland St. Helena, 20 Juni 1623 (Col. Coen I, p. 755 v.); Nadere verklaring van de effecten, die de Comp. in Indië volgens de balans in dato 31 Dec. 1623 was hebbende.

4) Vgl.: J. P. Coen c.s. aan beww., Batavia, 6 Sept. 1622 (Col. Coen I, p. 718 v.). Dr. H. P. N. Muller: De O. I. C. in Cambodja en Laos (Linsch. Ver. XIII), 's-Gravenhage 1917, p. XLII, geeft de onjuiste voorstelling, dat 't kantoor in Cambodja pas in of na 1623 gelicht zou zijn.

5) Vgl. ook nog over de lichting der vier kantoren Tiele-Heeres: Bouwstoffen II, p. XXXII; Elias II, p. 47.

6) Dit laatste bedroeg f 36812.13 .4 an Kustkleeden, d.i. Koromandelkleeden, en sandelhout. 
de Firando uit Siam naar Japan moest brengen ${ }^{1}$ ) (f 76652.18.13), dan bleef er f 233679.5 .9 over. Daarbij kwam nog het bovengenoemde sandelhout uit de Klein Tholen en Sincapura ${ }^{2}$ ), zoodat men mocht aannemen, aldus de meening in Batavia, dat met inbegrip daarvan er een 100000 realen van achten voor inkoop beschikbaar waren; men begrootte de peperhoeveelheid aan de Bocht voor 1622 op niet meer dan \pm 12000 zakken, die voor 60000 realen te krijgen zouden zijn. Er bleef dus nog ruim genoeg over voor Chineesche en andere waren $^{3}$ ).

De afloop van den handel viel evenwel niet mee: de peper was in Patani duur en schaarsch: slechts ongeveer 4800 zakken werden er in 1622 ingekocht ${ }^{4}$ ). Wat de andere artikelen betreft : aan porselein schijnen in Patani en Sangora ongeveer 3550 realen besteed te zijn. Wat de rest betreft, ontgaan ons de bijzonderheden ${ }^{5}$ ).

In 1623 werden wederom verschillende schepen naar het Noorden gezonden. In April vertrokken de jachten Zwarte Beer, Hazewind en Vos onder leiding van Philips Lucasz naar de bocht van Patani met een cargasoen Guzeratsche en Koromandelsche kleeden ter waarde van $f$ 71625.17.12, waarvoor men hoopte, 9000 zakken peper te kunnen inslaan ${ }^{6}$ ). Jan van Hasel werd met het schip Muiden naar Siam gezonden, om daar hertevellen te koopen. De Muiden moest hiermee dan naar Japan vertrekken, Van Hasel echter in Siam blijven om de daar nog uitstaande schulden te innen, voorzoover dat nog niet door den achtergelaten assistent Jan Janss. van Campen gedaan was. Met dit geld moest Van Hasel dan, als er een der jachten uit Patani in Ajudhja gekomen zou zijn, hiermee naar eerstgenoemde plaats

1) Zie p. 231 .

2) Zie p. 233 .

3) Vgl. over bovenstaande berekening: Copiebrief naar Patani aan Philips Lucasz, Batavia, 1 Mei 1622; idem naar Sangora aan Jan van Hasel, Batavia, 1 Mei 1622; Copie-res. van G.-G. en Raden, fort Batavia, 14 Juni 1622 (Col. Coen III, p. 872 v.) ; Copiebrief naar Patani aan Gerrit Frederiksz. Druyff, Batavia, 15 Juni 1622.

4) Tegen b.v. \pm 11890 zakken van de Westkust van Sumatra en Atjeh, en 15600 zakken van Jambi en Indragiri.

5) Zie: Copiebrief van J. P. Coen aan Houtman te Malleyo, Batavia, 28 Dec. 1622 (Col. Coen III, p. 263 v.); Pieter de Carpentier c.s. aan beww. te Amst., fort Batavia, 1 Febr. 1623; Factuur der goederen, gescheept door order van J. P. Coen in 't schip Mauritius, geteekend door Pieter de Carpentier, fort Batavia, 1 Febr. 1623; J. P. Coen aan beww., in de Mauritius bij 't eiland St. Helena, 20 Juni 1623 (Col. Coen I, p. 755 v.).

6) Er zou dan nog een ruim overschot voor andere artikelen overgebleven zijn! $Z$ ie boven. 
teruggaan, opdat aldus het bedrag voor den peperhandel nog versterkt werd.

Wat de peper betreft : in de bocht van Patani bleken maar 2400 zakken te krijgen. In Siam echter heeft Van Hasel 40000 hertevellen kunnen opkoopen, echter bij voorkoop, en eerst leverbaar in Mei $\left.1624^{1}\right)$.

In 1624 weder dezelfde energie in 't hoofdkantoor ten opzichte van de Noorderkwartieren. Eerst vertrok - 2 of 3 April - het schip Noord-Holland ${ }^{2}$ ) naar Siam, om o.a. de tegen Mei van dat jaar toegezegde 40000 hertevellen te laden. Aan het hoofd stond wederom Jan van Hasel. Daarna ging, den $8^{\text {en }}$ van dezelfde maand, Philips Lucasz naar de bocht van Patani, die hij ook in 1623 bezocht had, nu met de jachten Witte Beer en Westcappel ${ }^{3}$ ), met een cargasoen van $f \quad 63696.10 .7$, weer voornamelijk ter bevordering van den peperhandel. Een brief aan de koningin moest getuigen van de teleurstelling der Hooge Regeering, dat de beloften, aan Druyff gedaan ten opzichte van den handel op Malakka, niet waren nagekomen, maar in strijd daarmee dagelijks door die van Patani provisie aan de Portugeezen aldaar geleverd werd. Een waarschuwing tegen dergelijke practijken in 't vervolg moest worden verzacht door een kleine schenkage. De komst van Pataniërs in Batavia om daar te handelen, en ook om de bevolking dezer stad te vergrooten, moest nog eens extra door Philips Lucasz worden aanbevolen.

De opkoop van peper bleef, gelijk in 't vorig jaar, beneden de raming, maar niet weer in die mate: in plaats van \pm 8000 zakken verkreeg men er 4725.

Nog dient ten slotte vermeld, dat 22 Juli 1624 in Batavia een instructie werd uitgevaardigd voor de opperhoofden van het voor Bantam liggende jacht Klein Zeeland, die, met bestemming naar Siam, onderweg Patani moesten aandoen, om, zoo noodig, eenig

1) Vgl. over den handel in 1623: Tiele-Heeres: Bouwstoffen II, p. XXXIII; MacLeod I, p. 501; Copie-instructie voor Philips Lucasz en den raad der jachten Z warte Beer, Hazewind en Vos, fort Batavia, 3 April 1623; Copieinstructie voor Jan vàn Hasel en den raad van 't schip Muiden, Batavia, 3 April 1623; Pieter de Carpentier aan beww. te Amst., fort Batavia, 3 Jan. 1624; Kes. van G.-G. de Carpentier en Raden, Batavia, 2 Febr. 1624; idem, Batavia, 18 Mt. 1624; Copie-instructie voor Jan van Hasel en den raad van 't schip Noord-Holland, Batavia, 2 April 1624.

2) Vg1. p. 170. Dat Groeneveldt (p. 252) spreekt van het schip Nieuw Hollant, dat 3 April 1624 naar Siam werd gezonden, berust blijkbaar op verwarring.

3) Vgl. p. 170. 
kapitaal, dat van daar gemist zou kunnen worden, naar Siam te brengen $\left.{ }^{1}\right)^{2}$ ).

Waar aldus zulk een intensieve vaart met Compagnie's schepen bleef bestaan, is 't begrijpelijk, dat bij velen de vraag kon opkomen, of 't niet beter geweest was, althans de kantoren van Patani en Siam eenvoudig te handhaven. Het is dan ook zeker, dat op Coen ten dezen - en niet door de minsten - critiek is uitgeoefend. Pieter de Carpentier bijvoorbeeld, door Coen zelf na zijn eerste bewind als opvolger gewenscht, betreurt het opheffen van 't kantoor in Ajudhja zeer, ook al doordat de Compagnie daardoor kans loopt, den belangrijken handel in hertevellen en sapanhout op Japan te verliezen $\left.{ }^{3}\right)$. Hij smaakt dan tijdens zijn gouverneur-generaalschap de voldoening, dat het Siamsche kantoor - in 1625 - weer hersteld wordt ${ }^{4}$ ). En wat het hoofdkantoor Patani betreft, hier zijn het vooral Heeren XVII, die post factum het belang van dit handelscentrum zeer hoog aanslaan en op Coen's vonnis wenschen terug te komen. Den $10^{\text {en }}$ Augustus 1627, terwijl Coen, herbenoemd tot gouverneur-generaal, op weg naar Indië is, schrijven ze daarheen: „Wy bemercken, dat veele inconvenienten in Patany voorcomen, doordien aldaer geen comptoir en hebben, ende alsoo wy alles aenwenden tot meesten dienst van de Generaele Compagnie, daertoe wy oock meenden het lichten van 't comptoir in Patany soude hebben gestreckt, gelijck nu 't contrarie bevinden, soo vinden wy nu weder niet ondienstich, dat 't voorsz. comptoir wederom werde gerestabilieert, ' $t$ sy in Petanie ofte in Sangora, sooals U.E. best te rade sullen werden" ${ }^{5}$ ). Coen, die, gelijk zoo dikwijls, eigen inzicht tegenover dat van Heeren Meesters stelt, antwoordt 3 November 1628, dat de handelsvoorwaarden in de bocht van Patani in 't laatst

1) Het fregat, dat instructie en lading aan de Klein Zeeland moest brengen, trof dit jacht niet meer an: $25 \mathrm{Juli}$ was het reeds van Bantam naar Siam gezonden.

2) Vgl. over den handel in 1624 : Dagh-Register, gehouden int Casteel Batavia I, p. 42, 61 v.; Res. G.-G. de Carpentier en Raden, Batavia, 18 Mt. 1624; idem, Batavia, 28 Mt. 1624; Copie-instructie voor Jan van Hasel en den raad van 't schip Noord-Holland, Batavia, 2 April 1624; Copie-missive aan de koningin van Patani, Batavia, 7 April 1624; Copie-instructie voor Philips Lucasz en den raad van Witte Beer en Westcappel, Batavia, 7 April 1624; Res. van G.-G. de Carpentier en Raden, Batavia, 4 Mei 1624; Copie-instructie voor de opperhoofden van 't jacht Klein-Zeeland, Batavia, 22 Juli 1624; Pieter de Carpentier c.s. aan beww., Batavia, 27 Jan. 1625.

3) Zie Tiele-Heeres : Bouwstoffen II, p. XXXIII ; Tiele: Eur. 5, II, p. 307.

4) Zie Muller: Het land van den Witten Olifant, p. 137; Elias II, p. 49.

5) Copiebrief van Heeren XVII naar Indië, 10 Augustus 1627 (Col. Coen V, p. 775 v.). 
ongunstig geweest zijn: dure peperinkoop, lage prijzen voor de kleedjes, dat zijn de redenen, waarom in 1628 er zelfs geen schip heen gezonden is. De Heeren, vervolgt Coen, moeten kwalijk ingelicht zijn door diegenen, die hun hebben gezegd, dat kantoren in de Bocht noodig zijn ${ }^{1}$ ). En hierbij bleef het: nooit is het kantoor van Patani weer hersteld ${ }^{2}$ ).

Wat de hoofdfuncties van Patani voor de Compagnie betreft, peperinkoop en 't verwerven van Chineesche artikelen, het is duidelijk, dat de eerste de minst belangrijke was: peper was immers in allerlei andere plaatsen te verkrijgen. De Chineesche handel echter heeft nog een lange en moeizame geschiedenis gehad, die niet meer binnen het bestek van mijn onderwerp valt. Alleen nog een paar opmerkingen. We zagen reeds, dat men zich allerlei wegen had voorgesteld om buiten Patani het beoogde doel te bereiken: vestiging in Cochinchina, concentratie in Batavia, verovering van $\mathrm{Macao}^{3}$ ). Niets van dit alles komt tot stand. Tevergeefs heeft Cornelis Reyersz. in 1622 getracht, laatstgenoemde plaats aan de Portugeezen te ontrukken. Maar wel weet hij een Nederlandsche vestiging tot stand te brengen op een eiland ${ }^{4}$ ) van de Pescadores, bij de Chineesche kust, ten Oosten van Amoy. Deze vestiging brengt echter niets dan ellende met zich mee: de Chineezen verzetten zich resoluut tegen onze aanwezigheid op een eiland, dat ze onder hun jurisdictie rekenen, en Reyersz. besluit in October 1622 tot den oorlog. Deze levert niet het gewenschte resultaat, en zoo blijft de toestand onbevredigend, tot de vlootvoogd eindelijk in 1624 besluit, de Pescadores te verlaten en op het Oostelijker gelegen Formosa een nieuwe poging te wagen. Het reeds gestichte fort wordt in verband hiermee afgebroken. En het planFormosa slaagt: de Chineezen leggen hier den Nederlanders geen bezwaren in den weg.

Zoo is dan de tijd van zoeken en mislukkingen eindelijk voorbij, en voor onzen Chineeschen handel een toestand van stabiliteit bereikt, die bijna veertig jaren zal duren ${ }^{5}$ ).

1) Generale missive van J. P. Coen c.s., Batavia, 3 Nov. 1628 (Col. Coen V, p. 102 v.).

2) Wat Cambodja betreft, hier is volgens Muller: Cambodja en Laos, p. XLIII, in 1636 weer een factorii gesticht.

3) Vg1. hoofdstuk III.

4) Door de Nederlanders „Peho” genoemd.

5) Vgl. over deze ontwikkeling van den Chineeschen handel: Groeneveldt; Muller: Onze vaderen in China, Gids 1917, dl. I. 


\section{VERBETERINGEN.}

p. 68 r. 15: Van Niewenroode, lees: Van Nieuwenroode.

p. 79 r. 5 en 7: Macassar, lees: Makassar.

p. 89 r. 4: veoverd, lees: veroverd.

p. 91 r. 1: Heeren VII, lees: Heeren XVII.

p. 143 r. 12: Chochinchina, lees: Cochinchina. 


\section{LITERATUUR.}

Anderson (J.). English intercourse with Siam in the seventeenth century. London 1890.

Arthus, zie Indiae orientalis etc.

Begin ende Voortgangh van de Vereenighde Nederlantsche Geoctroyeerde Oost-Indische Compagnie. Amsterdam 1646.

Birdwood (G.) and Forster (W.), The First I.etter Book of the East India Company. London 1893.

Blankwaardt (W.). De faktorij der (O. I. Compagnie te Ayuthia. Neerlandia, 1921, p. 73 v.

Bry (De), zic Indiae orientalis etc.

Calendar of state papers, zie Sainsbury (W. Nö̈l).

Chijs (J. A. van der) e.a. J)agh-Register, gchouden int Casteel Batavia. Batavia-'s-Gravenhage 1887-1931.

Colenbrander (H. 'T.). Jan Pieterszoon Coen. Bescheiden ointrent zijn bedrijf in Indië. 's-Gravenhage 1919-193-.

Colenbrander (H. T.). Koloniale Geschiedenis. '-Gravenhage 1925-1926.

Dagh-Register, zie Chijs (J.A. van der) e.a.

Dam (Pieter van), zie Stapcl (F. W.).

Danvers (F, C.). The Portuguese in India. London 1894.

Danvers (F. C.) and Foster (W.). Letters Received by the East India Company from its Servants in the East. London 1896-1902.

Discours ende allertentie van de schepen Haarlem en Leiden van de vloot van Van Neck, Alkmaar en Wittc leeuw van de vloot van Jacob van Heemskerck, en de 14 schepen en een jacht onder Wijbrandt Warwijck, medegedeeld door P. A. Tiele. Bijdragen en Mededeeling:n Hist. Genootschap VI, 1883, p. 243 v.

Dijk (L. C. D. van). Iets over onze vroegste betrekkingen met Japan, zie denzelfde: Zes jarcn etc.

Dijk (L. C. D. van). Neĉrland's vroegste betrekkingen met Borneo, den Solo-archipel, Cambodja, Siam en Cochin-China. Amsterdam 1862.

Dijk (L. C. D. van). Zes jaren uit het leven van Wemmer van Berchem, gevolgd door Iets over onze vroegste betrekkingen met Japan (dit laatste apart gepaginẹer(). Amsterdam 1858.

Elias (J. E.). Het voorspel van den eersten Engelschen oorlog. 's-Gravenhage 1920.

Encyclopaedic van Nederlandsch-Indië, zie Paulus (J.) c.a.

Floris (Peter), zie Moreland (W. H.).

Foster (W.). The journal of John Jourdain. Hakluyt Society. Cambridge 1905. 
Fruin (R.). Een onuitgegeven werk van Hugo de Groot. Verspreide Geschriften III. 's-Gravenhage 1901, p. 367 v.

Groeneveldt (W. P.). De Nederlanders in China, Eerste stuk. Bijdragen tot de Taal-, Land- en Volkenkunde van Nederlandsch-Indië. 's-Gravenhage 1898.

Heeres (J. E.). Hendrik Janssen, een zeventiende-eeuwsche Groninger in Indië. Indische Gids, $18^{\mathrm{e}}$ jaarg. I, 1896, p. $101 \mathrm{v}$.

Heeres (J. E.) en Stapel (F. W.). Corpus Diplomaticum NeerlandoIndicum. 's-Gravenhage 1907-1935.

Hullu (J. de). De porceleinhandel der Oost-Indische Compagnie en Cornelis Pronk als haar teckenaar. Oud-Holland, 33 ${ }^{\circ}$ jaarg., 1915, p. $50 \mathrm{v}$.

Indiae orientalis pars octava, auctore M. Gotardo Arthus, uitgeg. door gebr. De Bry. Frankfort 1607.

Jonge (J. K. J. de). De opkomst van het Nederlandsch gezag in OostIndië - deel XI tot XIII bewerkt door M. L. van Deventer. -'s-Gravenhage-Amsterdam 1862-1888.

Jourdain (John), zie Foster (W.).

Kern (H.). Itinerario. Voyage ofte schipvaert van Jan Huygen van Linschoten naer Oost ofte Portugacls Indiën. Linschoten-Vereeniging II. 's-Gravenhage 1910.

Klerk de Reus (G. C.). Geschichtlicher Ueberblick der administrativen, rechtlichen und finanziellen Entwicklung der Niederländisch-Ostindischen Compagnie. Verhandelingen van het Bataviaasch genootschap van kunsten en wetenschappen, deel XIVII. Batavia-Solo en 's Hage, 1894.

Letters Received, zie Danvers (F. C.) and Foster (W.).

Linschoten (Jan Huygen van), zie Kern (H.).

MacLeod (N.). De Oost-Indische Compagnic als zeemogendheid in Azië. Rijswijk 1927.

Moreland (W. H.). Peter Floris his voyage to the East Indies in the Globe. Hakluyt Society. London 1934.

Muller (H. P. N.). De Oost-Indische Compagnie in Cambodja en Laos. Linschoten-Vereeniging XIII. 's Gravenhage 1917.

Muller (H. P. N.). Het land van den Witten Olifant en de factorijen der Compagnie aldaar. Vragen des Tijds $1912 \mathrm{I}$, p. 45 v. en 127 v.

Muller (H. P, N.). Onze vaderen in China. Gids 1917 I, p. 321 v.

Nachod (O.). Die Beziehungen der Niederländischen Ostindischen Compagnie zu Japan im siebzeinten Jahrhundert. Leipzig 1897.

Netscher (E.). De Nederlanders in Djohor en Siak. 1602 tot 1685. Verhandelingen van het Bataviaasch Genootschap van kunsten en wetenschappen, deel XXXV. Batavia 1870.

Nierop (L. van). De zijdenijverheid van Amsterdam historisch geschetst. Tijdschrift voor Geschiedenis, $45^{\circ}$ jaarg. 1930 , p. 18 v. en 151 v.

Overzigt der betrekkingen van de Nederlandsche Oost-Indische Compagnie met Siam. Tijdsclurift voor Indische Taal-, Land- en Volkenkunde van 't Bataviaasch Genootschap van kunsten en wetenschappen, deel XIII, 1864, p. 410 v. 
Paulus (J.) e.a. Encyclopaedie van Nederlandsch-Indië. $2^{\text {c }}$ druk. 's-Gravenhage $\rightarrow$ Leiden 1917-1927.

Purchas (S.). Hakluytus Posthumus or Purchas His Pilgrimes. Herdruk, Glasgow 1905-1907.

Rouffaer (G. P.) en Juynboll (H. H.). De Batikkunst in Nederlandsch Indië en haar geschiedenis. Utrecht 1914.

Rouffaer (G. P.) en IJzerman (J. W.). De eerste schipvaart der Nederlanders naar Oost-Indië. Linschoten-Vereeniging VII, XXV en XXXII. 's-Gravenhage 1915-1929.

Sainsbury (W. N.). Calendar of state papers. Colonial series (vols 2-4:) East Indies, China and Japan. 1513-1616, 1617-1621, 1622-1624. London 1862, 1870, 1878.

Stapel (F. W.). Pieter van Dam. Beschrijvinge van de Oostindische Compagnie. Gedeeltelijk verschenen. Rijks Geschiedkundige Publicatiën. 's Gravenhage 1927-1932.

Staring (W. C. H.). Maten, gewichten en munten. $4^{\mathrm{e}}$ dr. Schoonhoven 1902.

Terpstra (H.). Bezuinigingsmaatregelen van Jan Pietersz. Coen. Tijdschrift voor Geschiedenis, $49^{\mathrm{e}}$ jaarg. 1934, p. $15 \mathrm{v}$.

Terpstra (H.). De opkomst der Westerkwartieren van de Oost-Indische Compagnie. 's Gravenhage 1918.

Terpstra (H.). De vestiging van de Nederlanders aan de kust van Koromandel. Groningen 1911.

The First Letter Book of the East India Company, zie Birdwood (G.) en Foster (W.).

Tiele (P. A.). De Europeërs in den Maleischen Archipel 1519-1618, in: Bijdragen tot de Taal-, Land- en Volkenkunde van NederlandschIndië, $1877-1887$.

Tiele (P. A.), zie Discours ende advertentic etc.

Tiele (P. A.) en Heeres (J. E.). Bouwstoffen voor de Geschiedenis der Nederlanders in den Maleischen Archipel. 's Gravenhage 1886-1890.

Valentyn (F.). Oud en Nieuw Oost-Indiën. Dordrecht-Amsterdam $1724-1726$.

Wieder (F. C.). De reis van Mahu en de Cordes door de straat van Magalhães naar Zuid-Amerika en Japan. Linschoten-Vereeniging XXI, XXII en XXIV. 's Gravenhage 1923-1925.

Wood (W. A. R.). A history of Siam. London 1926.

Yule (H.) and Burnell (A. C.). Hobson-Jobson. A glossary of colloquial Anglo-Indian words and phrases etc. New Edition. London 1903.

IJzerman (J. W.). De reis orn de wereld door Olivier van Noort. Linschoten-Vereeniging XXVII en XXVIII. 's Gravenhage 1926.

IJzerman (J. W.). Hollandsche prenten als handelsartikel te Patani in 1602. Gedenkschrift Koninklijk Instituut voor de Taal-, Land- en Vokenkunde van Nederlandsch-Indië. 's Gravenhage 1926, p. 84 v. 


\section{REGISTER VAN PLAATS-, PERSOONS- EN SCHEEPS- NAMEN, IN DEN TEKST VOORKOMENDE. (De laatste zijn cursief gedrukt).}

Achter-Indië : 1, 13, 50, 74, 101.

Adams (William) : 49, 57.

Adriaensen (Jacob) : 45, 47, 60.

Adriaensz. (Adriaen) : 218.

Advice: 206.

Acolus: 80.

Aertss. (Pieter) : 30, 35, 61, 180.

Agoeng: 164.

Ajudhja: 45, 53, 60, 68 v., 75 v., 86, 94 v., 108, 166, 176 v., 197 v., 203, 229 v., $237,239$.

Alkmaar: 10, 15, 117, 154.

Amboina : 8, 71 v., 96, 140 v., 161, 169, $173,220$.

Amoy: 119, 240.

Amsterdam: 10, 20 v., 86, 92, 107, 119, 121, 125, 144, 151, 162, 180, 200.

Amsterdam: 5, 7, 27 v., 154, 186.

Androgerys : 207.

Annam : 83, 142.

Antheunis (Lucas), zie Antheunissen (Lucas).

Antheunissen (Lucas): 71, 195 v., 205.

Antoni (S.): 24 v., 186.

Antwerpen: 121.

Apius (Martinus): 38 .

Artss (Jan van -): $27 \mathrm{v}$.

Atjeh: 7 v., 18, 34, 71, 74, 106.

Baillij (Hans) : 51, 178.

Banda: 12, 53, 64, 126, 130, 137, 140, 160, 169, 173, 209, 220.

Banjermasin : 136.

Banka: 176.

Bantam : 1, 8, 10, 12 v., 18 v., 23, 25 v., 30,34 v., 44 v., 51 v., 54 v., 61 v., 69,71 v., 77 v., 81 v., 87 v., 91, 96 v.,
$120,125,128$ v., 131, 134, 136, 151, 153 v., $162,165,174$ v., 178,181 v., 188 v., 203 v., 212 v., 238.

Bantam: 65 v., $68,72,75$ v.

Bastiaensz. (Cornelis) : 26 v., 188.

Batavia: 67, 95, 100 v., 113, 117, 128, 131,158 v., 169 v., 172, 176, 178, 223 v., 227 v., 240.

Batjan: 140, 173.

Batosauwer: 187.

$B c \mathcal{~ : ~} 224$ v.

Bccr: 167.

België: 121.

Bengalen: 4.

Bergerboot: 96, 98, 102, 165 v., 213 v.

Bicker (Laurens): 7.

Bima: 165.

Bitter (Jacob de -) : 175.

Bloemaert (Samucl) : 30, 181.

Bodba : 144.

Bodman (Owen) : 211.

Boeckholt : 191.

Boeton: 73.

Bontekoe: 75 .

Bordelon: 67 v., 86, 105 v., 113, 136, 138, 144, 150, 156, 222, 228.

Borneo: 4, 21 v., 30, 35, 43, 61 v., 65, 74, 180 v., 204.

Borneo : 231.

Both (Pieter): 56, 60, 64, 68, 72, 76, 79, 125, 175 v., 191.

Brak: 56 v., 60, 63, 77.

Bremen (Jan Janssen van -) : 51, 190.

Broecke (Abraham van den -) : 37, 50, 72 v., 75 v., 78 v., 94, 138, 189, 200 v.

Broenei : 22, 180. 
Browne (John) : $207 \mathrm{v}$.

Bruinvisch: 231.

Bull: 115.

Buysen (Jacob) : 21.

Caerden (Paulus val _-): 43, 54, 161, 187.

Calanta (Radzia) : 25.

Cambodja: 4, 50 v., 67, 84, 90, 99 v., 104, 108 v., 136, 156, 164, 166, 168 v., 178 v., 182 v., 192,203 v., 227 v., 230 v., 235 v.

Campen (Jan Janss. van -) : 237.

Canton: 118, 130.

Cardossa (Joan - de Sosia) : 194.

Carpentier (Pieter de -) : 103, 158, 235, 239.

Catharina (S.): 12, 119, 186.

Ceilon: 18.

Champa, zie Tsi-ampa.

China: 5, 13 v., 21 v., 26 v., 33, 36 v., $39,48,91,93,118$ v., 125,131 v., 136 v., 141 v., $147,158,169,185,188$, 227, 233.

Chinceo: 136.

Chincheeuw : 142.

Chwan-chau: 122.

Claasz. (Willem), zie Clayss. (Willem).

Clayss. (Willem) : 125, 175.

Clove: 210, 223.

Cochinchina: 23, 67, 83 v., 90, 142 v., 158, 179, 182 v., 204, 240.

Cocks : 207.

Coen (Jan Pietersz.) : 1, 57, 64, 68 v., 73, 80 v., 83 v., 87 v., 91 v., 103 v., 108 v., $120,130,133,135$ v., 138,140 v., $145,147,149,151$ v., 155 v., 162 , 164 v., 169, 172, 176, 179, 182 v., 192 v., 195, 200, 204, 206, 208 v., 212 v., 220 v., 224, 226 v., 235, 239 v.

Colijn (Jacob - Jansz.): $228 \mathrm{v}$.

Comans (Cornelis) : 167.

Cooper (Ralph) : 199.

Copss. (Tuenis) : 44.

Cordes $(\mathrm{De}-)$ : 30 .

Coteels (Mateo): 64, 69, 72, 77 v., 129 v., 182, 200.

Craen (Hendrik Janssen) : $44 \mathrm{v}$.

Cunningen (Willem) : 108 v., 111.
Dabhol : 104.

Dale (Sir Thomas) : 210, 212.

Dam (Pieter van -) : 175.

Damascus : 122.

Danzig: 16.

Darling: $201 \mathrm{v}$.

Dato Bandharo: 232.

Dato Mugul: $68 \mathrm{v}$.

Dato Sirinara, zie Sirinara.

Davis : 202.

Delft : 21, 175, 180.

Delft: 53 v., 160 v., 180 .

Denton (Adam): 107, 196, 200 v., 203, 210, 213 v., 219, 222 v.

Diemen (Antonio van -): $94 \mathrm{v}$.

Dirkss. (Gerrit) : 12.

Dolphijn: 80, 101, 169, 229.

Domingo: 211.

Dordrecht: 27 v., 97.

Douglas (Adam) : 211.

Druyff (Gerrit Frederiksz.) : 94 v., 97, 99 v., 130, 135 v., 138 v., 144, 147, $149,152,157,159,163$ v., 179, 182 v., 193 v., $207,209,214,219$ v., 229 v., 234 v., 238.

Duitschland: 60, 157.

Dussen (Van der -) : 102, 175, 233.

Dijk (L. C. D. van -) : 31, 181.

Eaton (William) : 207.

Ebert (William) : 199.

Eenhoorn: 101, 169, 229 v.

Egbertss. (Egbert): 30, 34 v.

Ellertsen (Ellert) : 60, 75.

Empo: 22 v., 139 v., 148.

Engel: 96, 98, 165, 213 v.

Engeland: 199, 203, 217.

Enkhuizen : 18.

Enkhuizen (jacht): 66, 73, 75.

Enkhuizen (schip) : 82, 87 v., 208.

Erasmuls: 14, 36 v., 160.

Essington (Thomas): 196 v., 199.

Exchange: 223.

Firando, zie Hirado.

Firando: 231, 235 v.

Floris (Peter), zie Floris (Pieter Willemsz.).

-Floris (Pieter Willemsz.): 71, 195 v., $199 \mathrm{v}$. 
Fokien: 119, 122.

Foochow: 119.

Formosa: 84, 240.

Fortune: 223 v., 234.

Francx (Cornelis): 29 v.

Frankrijk: 60.

Furtado (Don Andrea), zie Mendoça (Andreas Furtado de -).

Gaermans (Jacob) : $110 \mathrm{v}$.

Galjas: 82 v., $100,102,109$ v., 135 ,

145 v., $155,168,230$.

Gelderland: 43 v., 55.

Gillman (Edward) : 214, 219.

Globe : 71, 76, 195 v., 210.

Goa: 105, 114, 187, 192.

Goede Hoop: 125, 155.

Goenoeng Nipiki: 1.

Gouda (jacht) : 5, 7, 154, 186.

Gouda (schip) : 39 v., 188.

Griffioen: 49, 56, 77, 108, 178 v., 189.

Grissee : 21, 136, 164.

Groesbergen (Gaspar van -) : 12 v., 19, $142 \mathrm{v}$.

Haarlem: 12 v., 19 v., 142.

Hackwell (Thomas) : 215.

Hagen (Steven van der -) : 26 v., 36, 126, 130, 137, 174 v., 186.

Hasel (Jan van - ) : 94, 106, 114, 152, $157,172,219,221,237$ v.

Hascuind: 65 v., .72, 78, 237.

Heemskerck (Jacob van -) : 10 v., 14 v., 20, 22, 119, 154, 160, 174, 176, 186.

Heeres (J. E.) : 57, 119, 183.

Heesen (Jan van der $\longrightarrow$ ) : 54 .

Hendrikss. (Pieter) : 45, $47,56$.

Hermite (Jacques l'-) : 20, 39, 41 v., $44,51,54,62,125,151,183$.

Heyn (Lambert Jacobsz.) : 22, 33 v., 45 v., 53, 59 v., 163,177 v.

Hippon (Anthony): 71, 196.

Hirado: 50, 56, 77, 82 v., 107, 179, 204, 207.

Hockseu: 119.

Hollandia (jacht), zie Klein Hollandia. Hollandia (schip) : 21, 26.

Hollandsche Tuin: 18 v., 154.

Hoochlant (Jan Janssen) : 210.

Hoop (jonk) : 89, 184.
Hoop (schip): 71, 73 v., 78, 138, 191.

Hoorn: 82.

Hoorn: 27.

Hope: 222 v.

Hormus : 122.

Houbraecken (Cornelis): 210, 212 v.

Hound: 96, 98, 166, 213.

Houtman (Frederik de -) : 27 v., 36.

Houtman (Marten) : 60, 68, 70, 75 v., 87 v., 94, 163, 177 v., 198, 200, 209.

Hoijer (IJsbrant Jacobss. de -) : 73.

Huyaert (Jan): 5 .

Huygens (Constantijn): 123.

Indra (Radgia): 166.

Indragiri : 152, 153 .Zie ook Androgerys.

Italië: $118 \mathrm{v}$.

Jacatra: 39, 73, 82 v., 95 v., 98 v., 105, 107,109 v., 112,115 v., $136,138,141$, 146 v., $156,158,164$ v., 171 v., 176 , 181, 194, 206, 210 v., 216, 218, 220, $229 \mathrm{v}$.

Jacatra: 80 v., $82,84,87,89,146,156$, 184, 192, 202, 208.

Jacobus I: 196.

Jager: 96 ,98, 166, 213 v.

Jambi : 1, 7, 39, 82 v., 91, 96, 98, 104, 152 v., 164, 166 v., 169, 206, 213 v., 228 v., 231 v.

James: $201 \mathrm{v}$. Zie ook James (ook little James genoemd).

Jannes (ook little James genoemd) : 206 v. Zie ook James.

Jang dipertoewan: 188.

Janssen (Evert) : 65 .

Janssen (Hendrik), factorijhouder in Patani: 29, 31 v., 37, 42, 45, 55 v., 61 v., 85 v., 106 v., 112 v., 120,128 v., 131 v., 134 v., 138,141 v., 144 v., 150,155 v., 162 v., 176,180 v., 191 v., 196, 198 v., 203,205 v., 212 v., 217, 219, 226.

Janssen (Hendrik), kwartiermeester op de Hazewind: 72.

Janssen (Jan - van Bremen), zie Bremen (Jan Janssen van -).

Janssen (Lucas), zie Antheunis (Lucas). Japan: 1, 20, 30 v., 48 v., 56 v., 65, 67, 
72, 77 v., 81 v., 86 v., $98,101,108$, $126,143,145$ v., $150,162,165$ v.; $169,172,178$ v., 189,203 v., 206 v.; 218, 227, 231, 237, 239.

Japara : 164.

Java: $67,114,130,142,164,173,220$ v. Joertan: 10 .

Johnson (John) : 196 v., 209.

Johor: 1, 10, 12, 18, 21, 23, 26, 28 v., $31,34,36$ v., 49 v., 55 v., 65 v., 71 v., $80,119,136,138,152$ v., 173 v., 176,186 v., 232.

Jonge (J. K. J. de - ) : 181.

Joosen (John) : 143.

Jourdain (John) (junior): 219, $223 \mathrm{v}$.

Jourdain (John) (senior): $213 \mathrm{v}$.

Kampar: 152.

Kistgens (Frederick): 191.

Klein Enkhuizen: 79 (zie ook noot 3 aldaar).

Kleine Zon: 43 v.

Klein Hollandia: 84 v., 95, 98, 100 v., 109, 114, 138, 164 v., 171, 194, 210, 219.

Klein Tholen: 169, 233, 237.

Klcin Zceland: 238.

Koromandel : 4, 65, 71, 103, 165, 169, 195, 197 v., 202 v., 208, 227.

Labestrate: 191.

Lam (Jan Dircksz. 't -) : 146.

Lamquin: 142.

Langeberque: 7.

Larkyn (Robert) : 201, 203, 208.

Lauweck: 110.

Leck (Daniël van der -): 9, 11 v., 19 v., $24,26,67$.

Leiden: 12 v., 143.

Liefde: 30.

I.ier (Hendrick van -) : 218.

Ligor: 2, 34, 67 v., 85 v., 93, 95, 105 v., 113 v., $136,144,150,152,156$, 163, 168, 194, 219, 222, 224, 228.

Littill (James) : 211 .

Littlewood (Robert): 199.

Lodenstein (Jan Joosten van -), zie Joosen (John).

Lubbeeck (Bertram): 103.

Lucasz (Philips): 151, 230, 237 v.
Macao: 5, 12, 24 ,37, 49, 82 v., 147, 187, 227, 240.

Mahu: 30.

Makassar: 54, 79, 140, 164.

Malakka: 1, 2, 4, 25, 31, 37 v., 51, 71, 105 v., 114 v., $139,152,167,171$, $174,176,185,187$ v., 193, 195, 227, 232, 235, 238.

Manilla: 147, 227.

Marlowe (Edmond) : $201 \mathrm{v}$.

Masulipatam: 195.

Mataram: 164.

Mataram (de) : 95, 164.

Matelief (Cornelis - de Jonge) : 31 , 33 v., 36 v., 39 v., 45, 48, 72, 128, $134,141,153,158,174$ v., 187 v., 227.

Mauritius : 144.

Mauritius: 33 v., 36 v., $125,128,187$.

Maurits : 27, 33, 48, 60, 142.

Medemblik: $27 \mathrm{v}$.

Meebael (Claes Simonsz.): 24, 26.

Me-kong: 110.

Mendoça (Andreas Furtado de -) : 25, 188.

Mere (Matthijs de -) : 56, 63, 94.

Mergui : 191.

Mibaise (Jean) : 104, 230.

Michiels'(Ferdinand) : 18, 26, 29 v., 61, 63, 154, 179 v.

Middelburg: 7, 36, 154.

Milde (De -) : 182.

Molukken : 28, 52 v., 57,63 v., 71, 73, $115,126,130,137,140,145$ v., 161 v., 169, 173, 193, 203, 209 v., 220.

Moone: 210.

Moreland (W. H.) : 201.

Morgenster (schip) zie Moryensterre (jacht).

Morgensterre (jacht): 96, 98, 100, 102,

141,165 v., 168 v., 171 v., 213 v., 218.

Muiden: 237.

Muller (H. P. N.) : 119.

Nagasaki : 50, 82, 187.

Nassau (jacht): 100, 168.

Nassau (schip): 14, 160.

Neck (Jacob van $\rightarrow$ ) : 2, 4 v., 20, 126,

128 v., 134 v., 142, 148, 150 v., 153 v., $158,160,174,186$. 
Nieuwenroode (Cornelis van -) : 60, 68,75 v., 85 v., $88,94,107$ v., 113 , $117,144,166,176$ v., 229 v., 233.

Nobelet (Willem) : 66, 68 .

Noord-Holland: 170, 238.

Obelaer (Jacques) : 50 .

Ockonchijn: 76.

Ockoncij : 34, 76. Zie ook Okonsiot.

Ocondanpon: $34 \mathrm{v}$.

Okonsiot: 76. Zie ook Ockoncij.

Oldenbarnevelt (Johan van - ) : 13.

Oranje (fort): 81 .

Oranje: $34 \mathrm{v}$.

Osiander: 204, 208.

Oude Zon: 145 v.

Oud-Zeelandia: 81,87 .

Padoucka Sarinara, zie Sirinara.

Pahang: 37, 41, 51, 54, 136, 152, 190 , 200.

Palembang: 167, 228, 231 v.

Panckeras (Jacob) : 210, 212 v.

Papegaaiken: 18.

Paquin: 142.

Paure: 53 v., 161, 163.

Pauwels (Jan): 186.

Peacock (Tempest) : 143.

Pegu: 158.

Peking, zie Paquin.

Peppercorn: 223.

Perre (Jacques van de -) : 30, 45 v., 59, 178.

Perzië: 118.

Pescadores: 170, 240.

Petapoelie: 196.

Philippijnen : 53, 160, 192.

Pieters (Hillebrant, bijgenaamd Verlangher): $43 \mathrm{v}$.

Pietersz. (Cornelis): 18 v., 154, 186 v.

Pietersz. (Rochus) : 5, 9.

Pnom-Penh: 110.

Poeloe Condor: 23, 67, 74.

Poeloe Pandjang: 210, 212.

Poeloe Tikus: 171, 205.

Poeloe Tioeman: 23.

Poelo Tijckos ,zie Poeloe Tikus.

Polen: 157.

Portugal: 114, 192.

Postpaard: 231, 233.
Poulo Tijcos, zie Poeloe Tikus.

Pratiau: 2, 8 v., 93.

Purmerend: 170.

Puyck (Nicolaas) : 50.

Quacckernaeck (Jacob Jansz.): $30 \mathrm{v}$, $48,179$.

Queda: 105, 152, 163.

Quinam: 142, 145 v.

Raeij (Henricq van -) : 51 v., 178.

Ranamanggala: 156.

Reael (Laurens) : 57, 95, 162, 173.

Redang: 167, 190.

Reyersz. (Cornelis) : 169, 233, 240.

Reynst (Gerard) : 162.

Rocff (Hans): 12, 30, 35, 61, 180.

Roekoe (Jan Dircxss.) : 37, 59 v., 68 v.

Roelofsz (Roelof): 127, 136, 153, 158, 160.

Roode Leeur met Pijlen: 49 v., 56, 77, 108, 178 v., 189.

Rotterdam : 9.

Rotterdam: 81.

Roussel (Jacques) : 23, 139.

Roy (Gerard le -) : 7 v.

Royal James: 223.

Rutgers (Albert): $61 \mathrm{v}$.

Ruyll (Albert Cornelisz.): 143.

Saberang: 2, 36.

Saberang (Radja): 188 v.

Sabran (Raga), zie Saberang (Radja).

Sambas: $62,180 \mathrm{v}$.

Sampson: 96, 98 v., 102, 115, 141, 166, 168, 210, 213, 215, 217, 220.

Sangora: 2, 34, 55, 67 v., 85 v., 91 v., 98 v., 106 v., 113 v., 118, 121, 128, $134,138,141,149,152,155$ v., 163 v., 168, 171 v., 176 v., 192, 194, 200, 202 v., 208,219 v., 226 v., 231,235 v., 239.

Santvoort (Melchior van -) : 31, 48, 50, 179.

Scharlaken (Jacob van $\longrightarrow$ ) : 175 .

Scharlaken (Jan van -) : 175.

Schot (Jacop die -) : 64 .

Segers (Peter): 29, 53 v., 56 v., 63 v., 125, 153.

Seijs (Pieter) : 111, 182.

Siam: 1 v., 12, 20 v., 24, 26, 29 v., 
32 v., 38,45 v., $53,55,59$ v., 63,68 , 70 v., 75 v., 86 v., 91, 94, 99 v., 104 v., 107 v., 117 v., $136,156,158,161$, 163 v., 167 v., 176 v., $178,184,191$ v., 196 v., 202 v., $213,222,224$ v., 227 v., 230 v., 235 v.

Sigismund III : 157.

Silva (Don Juan de -) : 192.

Sincapura: 169, 233, 237.

Sineau: 22.

Singapore: 192.

Siriaragoena : 68 .

Sirinara: 6,18 v., 22,218 v.

Skinner (John) : 197.

Smidt (Dirk Evertsen) : 40.

Soekadana: 30, 35, 61 v., 136, 169, 180 v., 201, 204, 213.

Soenda (straat): 39 .

Soerabaja : 164, 178.

Soldt (Paulus van - ) : 125.

Solomon : 204, 208.

Solor: 26, 126, 134.

Soury (Andries) : 91.

Spanje: 49, 227.

Specx (Cornelis) : 22, 24, 26, $33 \mathrm{v}$.

Specx (Jacques) : 50, 77, 82, 87, 89, 145, 147, 165, 182.

Speult (Van -) : 216.

Sphera Mundi: 21 v.

Sprinckel (Victor) : 20, 31, 37 v., 40 v., 50 v., 53 v., 62,77 v., 108, 125, 132 v., $137,151,154,160$ v., 177 v., 183 , $185,189 \mathrm{v}$.

Steenroot (Cornelis van -), zie Vlieroot (Cornelis van -).

Steyns (Jan) : 232.

Stollenbeecker (Johannes): $27 \mathrm{v}$.

Suratte: 4, 202, 204, 227.

Tachem: 143.

Tenasserim: 105, 158, 191.

Ternate: 5, 37, 43, 54 v., 81, 173.

Theunemans (Abraham): 73, 191.

Tholen: 100 v., 169,230 v.

Timor: 126, 134.
Tinhongh: 165, 167.

Tittjuhou: 142.

Tonneman (Willem Pietersen) : 30, 45 v., 59, 178.

Toornenburch (Cornelis Claesz.): 143.

Tsi-ampa: 37, 43, 143, 166.

Tsuentschou: 119. Zie ook Chinceo, Chincheeuw, Chwan-chau en Sineau.

Unicorn: 223.

Varela (kaap) : 74.

Verhoeff (Pieter Willemsz.) : 49 v., 53, 55, 60, 125, 129 v., 160, 163, 175, 189.

Verhult : 233.

Verschoor (Jan Willemsz.) : 30 .

Vliegende Bode: 147.

Vlieroot (Cornelis van -): 175.

Vlissingen: 56.

Vlissingen: 21, 23, 25 v., 188.

Vos: 99 v., 108 v., 167, 194, 231, 233, $236 \mathrm{v}$.

Vosje, zie Vos.

Walichsz. (Pieter): 9, 12.

Warwijck (Wijbrand van -) : 14, 18, 21 v., 33, 45, 124, 139, 180, 186, 188.

Weert (Sebald de $\rightarrow$ ) : 18.

West-Cappcl : 170, 234, 236, 238.

Willemsen (Isack) : $59 \mathrm{v}$.

Willemsz. (Pieter), zie Floris (Pieter Willemsz.).

Witte Beer: 170, 238.

Witte Lecurv: 10, 15, 154.

Wittert: 53, 160.

Wonderaer (Jeronimus) : 143.

IJzerman (J. W.) : 15.

Zaitun, zie Chwan-chau.

Zeeland: 7, 125, 139.

Zeelandia: 7.

Zecwolf: 99, 102, 104, 110, 157, 168, 171.

Zierikzee: 18 v., 154.

Zon: 7, 154.

Zrvarte Beer: 233 v., 237.

Zwarte Leeuzv: 82 v., 94 v., 107, 112,

128, 145 v., 156, 165, 184, 210 v., 222. 


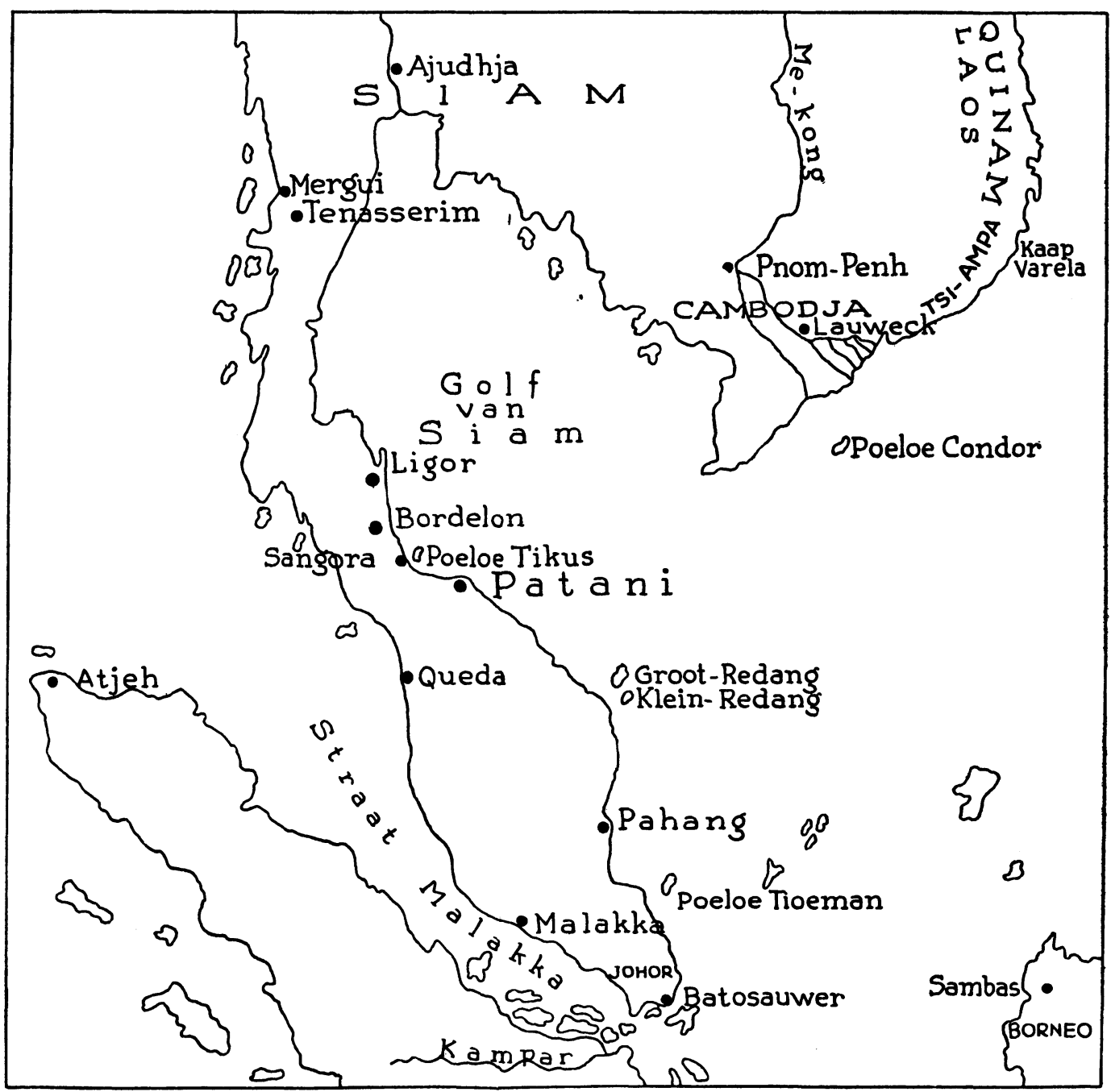





\section{N HO U D.}

EERSTE HOOFISTUK: De Nederlanders in Patani tijdens de Voorcompagnieën . . . . . . . . . . 1

TWEEI)E HOOFDSTUK: De Nederlanders in Patani tijdens de Oostindische Compagnie.

a. Tot den dood van Ferdinand Michiels (1603-1607)

b. Het eerste bewind van Hendrik Janssen en dat van Victor Sprinckel (1607-1611) . . . . . . . . 31

c. De tweede bewindsperiode van Hendrik Janssen (1611-1613) . . . . . . . . . . . . . . 63

d. Abraham van den Broecke en het derde bewind van Hendrik Janssen (1613--1618) . . . . . . . . 78

e. Het bewind van Gerrit Frederiksz. Druyff (16181621)

DERDE HOOFDSTUK: De Chineesche handel in Patani. 118 VIERDE HOOFDSTUK: De peperhandel . . . . . . 148

VIJFDE HOOFDSTUK: Verder nut van Patani . . . 160

ZESDE HOOFDSTUK: Patani als politieke en economische factor van de Compagnie . . . . . . . 174

ZEVENDE HOOFDSTUK: Portugeezen en Engelschen. 185

ACHTSTE HOOFDSTUK: De opheffing van de factorij te Patani.

Verbeteringen . . . . . . . . . . . . . . . . . 241

Literatuur . . . . . . . . . . . . . . . . . . 242

Register van plaats-, persoons- en scheepsnamen, in den tekst voorkomende . . . . . . . . . . . . . . 245

Schetskaartje. 